\title{
Reconnaissance Investigation of Water Quality, Bottom Sediment, and Biota Associated with Irrigation Drainage in the Columbia Basin Project, Washington, 1991-92
}

By S. S. Embrey and E. K. Block

\section{U.S. GEOLOGICAL SURVEY}

Water-Resources Investigations Report 95-4007

Prepared in cooperation with the U.S. GEOLOGICAL SURVEY, U.S. FISH AND WILDLIFE SERVICE, BUREAU OF RECLAMATION, and BUREAU OF INDIAN AFFAIRS

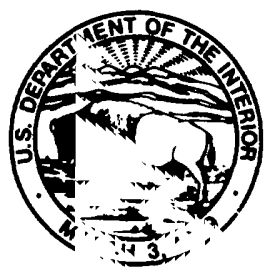




\title{
U.S. DEPARTMENT OF THE INTERIOR
}

BRUCE BABBITT, Secretary

\section{U.S. GEOLOGICAL SURVEY}

\author{
Gordon P. Eaton, Director
}

Any use of trade, product, or firm names is for descriptive purposes only and does not imply endorsement by the U.S. Geological Survey.

For additional information write to:

District Chief

U.S. Geological Survey

1201 Pacific Avenue, Suite 600

Tacoma, Washington 98402
Copies of this report may be purchas $9 \mathrm{~d}$ from:

U.S. Geological Survey

Earth Science Information Center

Open-File Reports Section

Box 25286, MS 517

Denver Federal Center

Denver, CO 80225 


\section{CONTENTS}

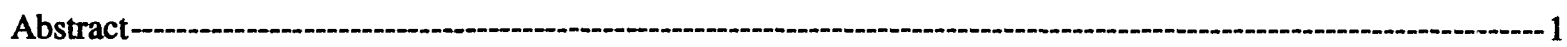

Introduction -

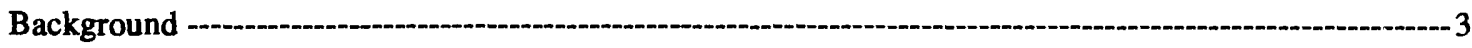

Purpose and scope--

Acknowledgments - 5

Description of the study area - 5

History --

Wildlife and fisheries - -

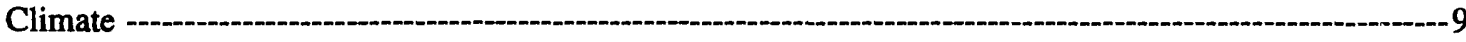

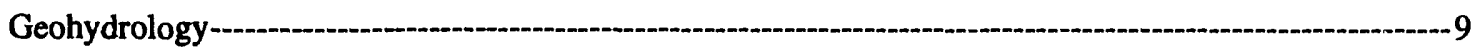

Soils and agriculture - 11

Surface-water hydrology - 14

Irrigation delivery system -- 14

Irrigation return-flow system -.-- 14

Previous studies - 19

Sample collection and analysis - 22

Water - 32

Bottom sediment --10-1- 33

Biota - 33

Bird eggs --1-- 34

Juvenile birds ---:- 34

Fish---1-- 34

Plants---1-- 35

Invertebrates --.-- 35

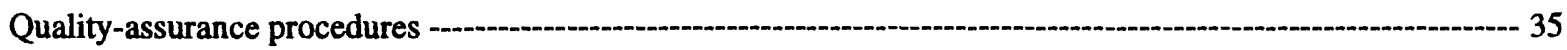

Discussion of results- 37

Characteristics of sampled water-1- 38

Field measurements-- 38

Dissolved solids, major ions, and nutrients- 38

Trace elements---.-- 42

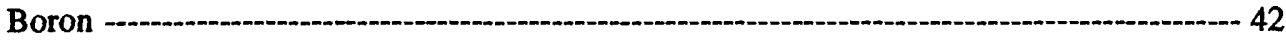

Molybdenum - 44

Uranium ---1-- 44

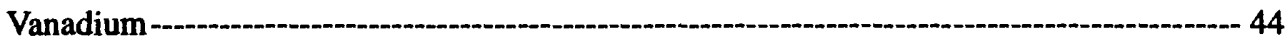

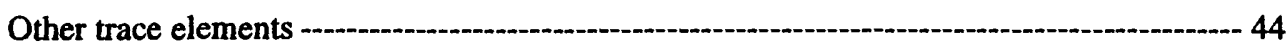

Pesticides -.--1.-- 45

Concentrations of constituents in bottom sediment - 46

Concentrations of constituents in biota-- 50

Trace elements-1- 51

Arsenic--1- 51

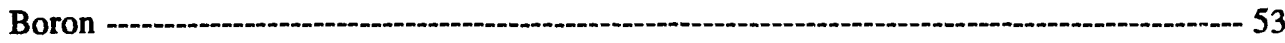

Cadmium - - 53

Chromium --.-1- 53

Copper - - 58 


\section{CONTENTS--Continued}

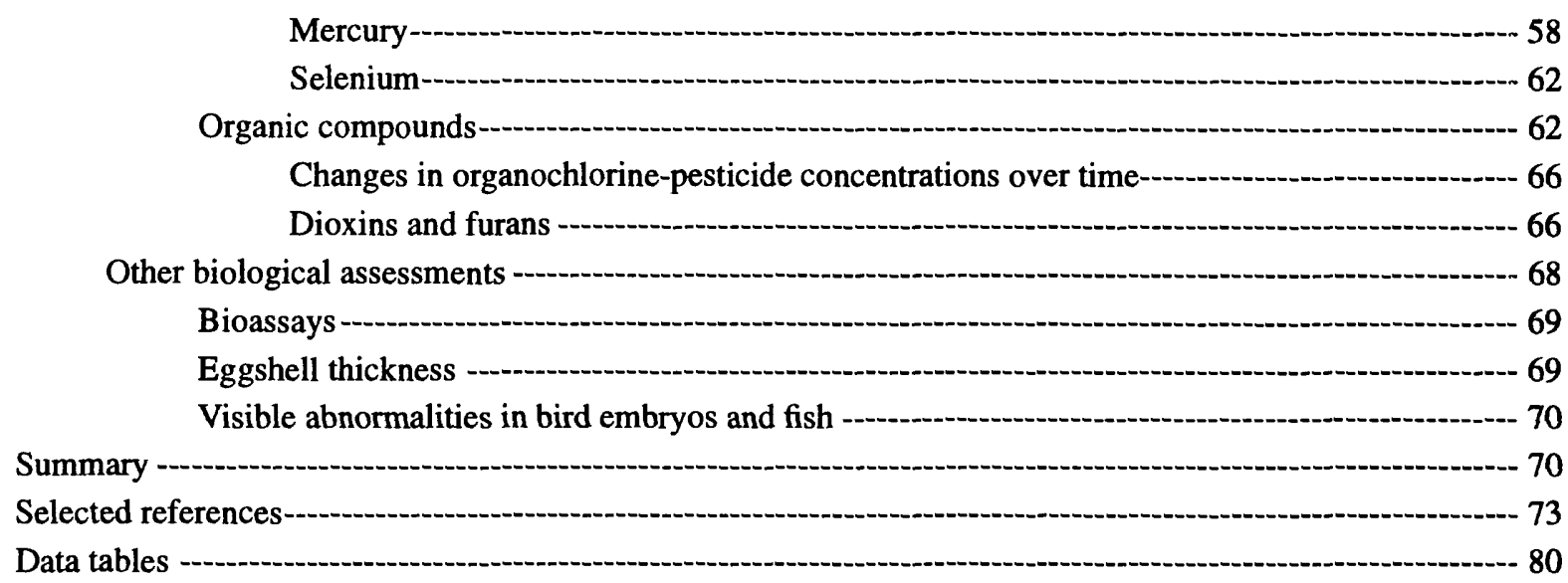

\section{FIGURES}

1. Map showing location and major features of the Columbia Basin Project in Washington State -

2. Map showing Federal National Wildlife Refuges and State Wildlife areas in the Columbia Basin Project

3. Bar charts showing long-term average precipitation (1951-80) and monthly precipitation for the years 1991 and 1992 at Ephrata, Washington-- 10

4. Map showing distribution of the applications of surface water and ground water for irrigation----- 12

5. Hydrograph showing monthly mean discharge for Crab Creek near Beverly, Washington, and for Rocky Ford Creek near Ephrata, Washington - 15

6. Bar chart showing long-term (1970-92) mean monthly discharges in Crab Creek near Beverly, and the monthly mean discharges during calendar years 1991 and 1992

7. Schematic diagram of water movement through the Columbia Basin Project and the principal reservoirs and lakes

8. Hydrograph showing adjusted monthly mean discharge in Main Canal below Billy Clapp Lake for the period 1960-92, and bar chart showing adjusted mean monthly discharge in Main Canal below Billy Clapp Lake for the period 1970-92, and the adjusted monthly mean discharges for calendar years 1991 and 1992

9. Map showing 24 sampling sites for water quality, bottom sediment, and biota in the Columbia Basin Project study area, 1991-92

10. Graph showing concentrations of dissolved solids in water samples from the Columbia Basin Project, November 1991, March 1992, and July 1992

11. Bar chart showing dissolved nitrate-nitrogen concentrations in water samples from the Columbia Basin Project, November 1991, March 1992, and July 1992 


\section{FIGURES--Continued}

\section{2-15. Graphs showing:}

12. concentrations of chromium in fish samples from the Columbia Basin Project--

13. concentrations of copper in fish samples from the Columbia Basin Project-- 59

14. proportion of the $o, p^{\prime}$ isomers of total DDT to the $p, p^{\prime}$ isomers of total DDT in carp and perch samples from the Columbia Basin Project--- 64

15. DDT concentrations in fish samples collected from the Columbia Basin Project during $1977-85$ and in 1992

\section{TABLES}

1. Common and scientific names and endangerment status of species in or near wetlands and shrub-steppe habitat within the Columbia Basin Project, Washington -

2. Pesticides commonly used on farms in the Columbia Basin Project-

3. Location of sampling points where water, bottom sediment, and biota were collected in the Columbia Basin Project

4. Sampling sites, types of constituents analyzed for, and schedule of sampling for water and bottom sediment in November 1991, March 1992, and July 1992 in the Columbia Basin Project

5. Sampling sites, time of collection, and types of analyses for biota collected in 1992 in the Columbia Basin Project---.-.-.-- 28

6. Analytical reporting limits for selected trace elements in water, bottom sediment, and biota------- 29

7. Compounds and analytical reporting limits for selected organic compounds in water, bottom sediment, and biota-- 30

8. Type and number of water-quality assurance samples collected during the study, 1991-92--------- 36

9. Results of analyses for inorganic constituents in blank-water samples prepared during sample collection in November 1991, March 1992, and July 1992-- 36

10. Summary of properties and inorganic-constituent concentrations in water samples collected from the Columbia Basin Project in November 1991, March 1992, and July 1992------------- 39

11. Drinking water standards and water-quality criteria of selected constituents and properties for the protection of freshwater aquatic life and for the purposes of irrigation and livestock watering

12. Summary of insecticides, herbicides, and other organic compounds in water samples from the Columbia Basin Project, November 1991, March 1992, and July 1992

13. Summary of trace-element concentrations in bottom-sediment samples from the Columbia Basin Project and geochemical baseline concentrations for soils from the western United States

14. Summary of insecticides and other organic compounds in bottom-sediment samples from the Columbia Basin Project, July 1992

15. Arsenic concentrations in biological samples from the Columbia Basin Project and criteria or concentrations observed in biota from other studies used for comparison 
16. Boron concentrations in biological samples from the Columbia Basin Project and criteria or concentrations observed in biota from other studies used for comparison

17. Cadmium concentrations in biological samples from the Columbia Basin Project and criteria or concentrations observed in biota from other studies used for comparison

18. Chromium concentrations in biological samples from the Columbia Basin Project and criteria or concentrations observed in biota from other studies used for comparison -

19. Copper concentrations in biological samples from the Columbia Basin Project and criteria or concentrations observed in biota from other studies used for comparison

20. Mercury concentrations in biological samples from the Columbia Basin Project and criteria or concentrations observed in biota from other studies used for comparison

21. Selenium concentrations in biological samples from the Columbia Basin Project and criteria or concentrations observed in biota from other studies used for comparison --

22. Summary of total chlordane, total DDT, and dieldrin concentrations in biological samples from the Columbia Basin Project, summer 1992 -

23. Concentrations of dioxins and furans in whole longnose suckers collected from Billy Clapp Lake (site BCL), 1992

24. Eggshell thickness for coot, mallard, and western grebe eggs collected from the Columbia Basin Project in 1992 and thickness of eggs collected before the use of DDT (before about 1940) 6

25. Field measurements and results of analyses for inorganic constituents in filtered water samples from the Columbia Basin Project, November 1991, March 1992, and July 1992 -ב- 1

26. Results of analyses for insecticides, herbicides, and other organic compounds in whole water samples from the Columbia Basin Project, November 1991, March 1992, and July 1992--.---. \&?

27. Results of analyses for total trace elements and carbon in the less-than-2-millimeter size fraction of bottom-sediment samples from the Columbia Basin Project, July 1992

28. Results of analyses for pesticides and other organic compounds in the less-than-2-millimeter size fraction of bottom-sediment samples from the Columbia Basin Project, July 1992 ------- 1C3

29. Measurements of mallard, western grebe, and American coot eggs collected from the Columbia Basin Project. in 1992--

30. Concentrations of trace elements (wet weight) in fish, birds, snails, and pondweed collected from the Columbia Basin Project in 1992-

31. Concentrations of trace elements (dry weight) in fish, birds, snails, and pondweed collected from the Columbia Basin Project in 1992

32. Concentrations of trace elements in bird eggs collected from the Columbia Basin Project in 1992

33. Concentrations of organochlorine compounds (wet weight) in fish, bird eggs, and bird tissues collected from the Columbia Basin Project in 1992

34. The percent mortality and weight change of Chironomus tentans after exposure to bottom sediment collected from the Columbia Basin Project in July 1992 


\begin{tabular}{rcc}
\hline Multiply & By & To obtain \\
inch (in.) & 25.4 & millimeter \\
foot (ft) & 0.3048 & meter \\
mile (mi) & 1.609 & kilometer \\
square mile (mi $\left.{ }^{2}\right)$ & 4,047 & square meter \\
acre-foot $(\mathrm{acre}-\mathrm{ft})$ & 2.590 & square kilometer \\
cubic foot per second $\left(\mathrm{ft}^{3} / \mathrm{s}\right)$ & 1,233 & cubic meter \\
degrees Fahrenheit $\left({ }^{\circ} \mathrm{F}\right)$ & 0.028317 & cubic meter per ser:ond \\
\hline
\end{tabular}

Chemical concentrations in water are given in metric units. Milligrams per liter $(\mathrm{mg} / \mathrm{L})$ are approximately exual to parts per million (ppm), and micrograms per liter $(\mu \mathrm{g} / \mathrm{L}$ ) are approximately equal to parts per billion (ppb).

Chemical concentrations in bottom sediment and biota are reported as weight per unit of weight. Abundant elements in bottom sediment, such as iron, are reported in weight percent. Trace elements such as selenium are repor'ed in micrograms per gram $(\mu \mathrm{g} / \mathrm{g})$, which is equivalent to parts per million. Concentrations reported in picograms per gram $(\mathrm{pg} / \mathrm{g})$ are equivalent to parts per trillion.

Sea level: In this report "sea level" refers to the National Geodetic Vertical Datum of 1929 (NGVD of 1929)--a geodetic datum derived from a general adjustment of the first-order level nets of both the United States and Canada, formerly called Sea Level Datum of 1929. 


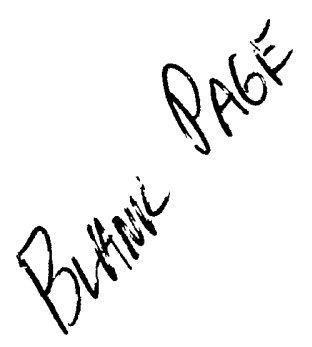




\title{
Reconnaissance Investigation of Water Quality,
}

\section{Bottom Sediment, and Biota Associated with}

\section{Irrigation Drainage in the Columbia Basin Project,}

\section{Washington, 1991-92}

\author{
By S.S. Embrey and E.K. Block
}

\begin{abstract}
During a reconnaissance-level investigation in 1991-92, information was collected to determine if irrigation drainage from the Columbia Basin Project has caused or has potential to cause harmful effects on human health or fish and wildlife, or might adversely affect the suitability of water for beneficial uses. Results of the study generally indicated no adverse effects on biota due to traceelement concentrations in irrigation drainage. However, boron concentrations in aquatic plants might affect waterfowl feeding on these plants. Also, arsenic concentrations in coots were similar to those in mallards exhibiting some abnormalities after being fed an arsenic-supplemented diet during laboratory studies.
\end{abstract}

In surface water, concentrations of dissolved constituents were small and with few exceptions did not exceed various standards or criteria protecting humans, freshwater life, and beneficial uses of the water. Dissolved solids, nitrate, boron, molybdenum, and vanadium concentrations generally increased in a downstream direction corresponding to water reuse throughout the Columbia Basin Project. Concentrations also varied seasonally. During non-irrigation season (November-March) when stream flows are sustained by return water from tile drains and ground water, constituent concentrations tended to be larger than during irrigation season. During irrigation season (AprilOctober) concentrations are diluted by source water from the Columbia River. During non-irrigation season dissolved solids exceeded 500 milligrams per liter and nitrate exceeded 10 milligrams per liter in some wasteways in the southern part of the study area. Most of the types of pesticides analyzed for in the 51 water samples were less than analytical reporting limits. Of the pesticides detected, there were 18 detections of insecticides and 31 detections of herbicides, most of which were observed in the July samples. The maximum observed dieldrin concentration ( 0.014 micrograms per liter) exceeded the chronic criterion for the protection of aquatic life. The herbicide 2,4-D was detected in more samples than any other pesticide and in concentrations as large as 1.0 microgram p 2 liter.

In bottom sediment, many trace elements of interest were present only in small concentrations nea- the analytical reporting limits. One selenium concentration exceeded 4.0 micrograms per gram, a value of concern for wildlife. Median concentrations of all trace elements of interest were within the baseline range of concentrations for soils in the Western United States. The maximum observed concentrations of selenium, uranium, and marganese exceeded the upper value of the baseline rang ${ }^{\circ}$. Analyses of bottom-sediment samples indicated that a variety of pesticides in detectable concentrations are widespread throughout the study area; 19 of 21 samples had at least 1 detection of some insecticide. Dieldrin, DDT, and DDE are still prevalent in much of the area. Methoxychlor, which was applied for mosquito control, was found in samples from nine of the sites in concentratiors as large as 2.4 micrograms per kilogram.

In biota, particularly in a large percentage of fish, concentrations of arsenic, boron, cadmium, cl romium, and copper were elevated in some of the samples compared with published standards, criteria, or baseline values from other studies. In addition to fish, cadmium and copper concentrations were elevated in some of the snail samples, and chromium concentrations were elevated in 
pondweed. Elevated copper concentrations in biota are probably due to copper sulfate used as an algicide in the canals. Mercury and selenium were not elevated in biological tissues. Organochlorine pesticides and related compounds were generally detected in small concentrations. In fish samples collected from some wasteways, concentrations of total chlordane, total DDT, and dieldrin exceeded criteria for the protection of fish health and of fish-eating predators. Compared with data collected in past years, total DDT concentrations in carp and perch have shown little change with time. Concentrations of DDT have declined little over the past 15 years, contrary to the significant decline in concentrations of DDT compounds observed in nationwide monitoring programs. Chlordane, detected only infrequently during past years, was detected in about 70 percent of the 1992 samples. In addition, chlordane concentrations observed in several fish samples were about twice the historical maximum concentration of 0.07 micrograms per gram. However, changes in laboratory methods and some differences in sampling sites limit the accuracy in comparing these data sets over time.

Other types of biological assessments used in this study indicated few or no adverse effects to biota in the study area. Surface water was not toxic to Daphnia magna and sediment bioassays showed moderate toxicity to Chironomus tentans in 9 of 21 samples. External lesions in fish were observed only infrequently; no abnormalities were observed in bird embryos, and eggshell thicknesses of mallard and grebe eggs were similar to those of the pre-DDT era.

\section{INTRODUCTION}

During the last several years, there has been increasing concern about the quality of irrigation drainage and its potential harmful effects on human health, fish, and wildlife. Concentrations of selenium greater than waterquality criteria for the protection of aquatic life (U.S. Environmental Protection Agency, 1987) have been detected in surface and subsurface drainage from irrigated land. In 1983, incidences of mortality, congenital deformaties, and reproductive failures in waterfowl caused by large concentrations of selenium were discovered by the U.S. Fish and Wildlife Service (USFWS) at the Kesterson National Wildlife Refuge in the western San Joaquin Valley of California where irrigation drainage was impounded. In addition, toxic and potentially toxic trace elements and pesticide residues have been detected in other western State areas that receive irrigation drainage (Feltz and others, 1990).
Because of concerns expressed by Congress, the U.S. Department of the Interior (DOI) started the National Irrigation Water Quality Program (NIWQP) in October 1985 to identify the nature and extent of irrigation-induced water-quality problems that might exist in western States. The DOI developed a management strategy and formed an interbureau group known as the Task Group on Irrigation Drainage that prepared a comprehensive plon for reviewing irrigation-drainage concerns for which the DOI could have responsibility.

Initially, the task group identified 20 areas in 13 States that warranted reconnaissance-level investigations related to three specific activities: (1) irrigation or drainage facilities constructed or managed by the DOI; (2) National Wildlife Refuges managed by the DOI; and (3) other migratory-bird or endangered-species management areas that receive water from DOI-funded p-ojects.

Nine of the 20 areas were selected for reconnaissance investigations during 1986-87:

Arizona-California: Lower Colorado-Gila River Valley area

California: Salton Sea area Tulare Lake Bed area

Montana: Sun River Reclamation Project area Milk River Reclamation Project area

Nevada: Stillwater Wildlife Mrnagement area

Texas: Lower Rio Grande-Laquna Atascosa National Wildlife Refuge area

Utah: Middle Green River B asin area

Wyoming: Kendrick Reclamatior Project area

On the basis of results of these investigatiors, detailed studies were begun in 1988 in four areas: Salton Sea, Stillwater Wildlife Management, Middle Green River Basin, and Kendrick Reclamation Project.

Eleven more reconnaissance investigations were begun in 1988:

California: Sacramento Refuge Complex California-Oregon: Klamath Basin Refuge, Complex

Colorado: Gunnison and Uncom nahgre River Basins and Sweitzer Lake Pine River Project

Colorado-Kansas: Middle Arkansas River Basin 
Idaho: American Falls Reservoir

New Mexico: Middle Rio Grande Project and Bosque del Apache National Wildlife Refuge

Oregon: Malheur National Wildlife Refuge

South Dakota: Angostura Reclamation Unit Belle Fourche Reclamation Unit

Wyoming: Riverton Reclamation Project.

On the basis of results of these 1988 investigations, and a continuing evaluation of all data for the NIWQP, three more detailed studies were begun in 1990:

\section{California-Oregon: Klamath Basin Refuge Complex \\ Montana: Sun River area \\ Colorado: Gunnison River Basin/Grand Valley Project.}

In October 1990, four reconnaissance investigations were begun and another started in October 1991:

\section{Oregon-Idaho: Owyhee-Vale Projects \\ Nevada: Humboldt Wildlife Management Area \\ Colorado: Dolores Project area \\ New Mexico: San Juan River area \\ Washington: Columbia Basin Project area.}

All reconnaissance investigations are conducted by interbureau study teams composed of scientists from the U.S. Geological Survey (USGS) as team leaders, with additional USGS, USFWS, Bureau of Reclamation (BR), and Bureau of Indian Affairs (BIA) scientists representing several different disciplines. The investigations are directed toward determining whether irrigation drainage (1) has caused or has the potential to cause significant harm to human health, fish, and wildlife or (2) could adversely affect the suitability of water for other beneficial uses.

\section{Background}

Adverse effects on waterfowl and other wildlife are commonly caused by increased salinity and increased concentrations of trace elements that have leached from soils into irrigation return water. The problem of increased trace-element concentrations in return-flow water is compounded by the high evaporation rates in arid lands, which further concentrate contaminants (Lemly and others,
1993). In reconnaissance studies of irrigation drainage in the western states, selenium, boron, arsenic, and mercury are the constituents found most often in elevated concentrations in water, bottom sediment, and biota (Feltz and others, 1990).

Investigations of water quality and the health of fish in the irrigated part of the Columbia Basin Project (CBP) (fig. 1) have identified problems or potential problems associated with agriculture and agricultural practices. Certain pesticides used in the past, such as DDT, are persistent in the environment, and have been detected in soils, surface water, well water, and fish tissue from locations within the CBP. The BR (1982) summarized data collected during 1974-78 and reported that concentrations of DDT, its metabolites, and dieldrin in fish from many of the irrigation waterways in the CBP area exceeded the geometric mean from the 1980-1981 National Contaminant Biomonitoring Program (NCBP) (Schmitt and others, 1990) conducted by the USFWS. Nitrate concentrations in wasteways to Potholes Reservoir and in the ground water in parts of Franklin County have exceeded $10 \mathrm{mg} / \mathrm{L}$ (milligrams per liter) as nitrogen (Drost and others, 1989), and mercury and boron were present in large concentrations in certain irrigation terminus ponds (J. W. Keys, Bureau of Reclamation, written commun., 1987).

The CBP was selected for reconnaissance study because the area has water-quality factors in common with other NIWQP studies. These factors include geologic sources of certain trace elements that could affect traceelement concentrations in water and bottom sediment; internal drainage basins or sinks; an arid to semiarid climate where precipitation is low (less than or equal to 12 inches per year); and irrigated agriculture in which irrigation drainage makes up a large part of the water supply to refuges and wetlands (Sylvester and others, 1988).

\section{Purpose and Scope}

The purpose of this report is to describe the results of a reconnaissance investigation of the CBP to determine if irrigation drainage has affected or has the potential to adversely affect human health, fish, and wildlife populations, or other beneficial water uses. Water, bottomsediment, and biological samples were collected from several sites within the CBP from November 1991 to July 1992 , and analyzed for concentrations of selected inorganic and organic compounds. These concentrations were then compared with various water-quality criteria or standards, published literature values, and baseline values for the study area or for other locations. 


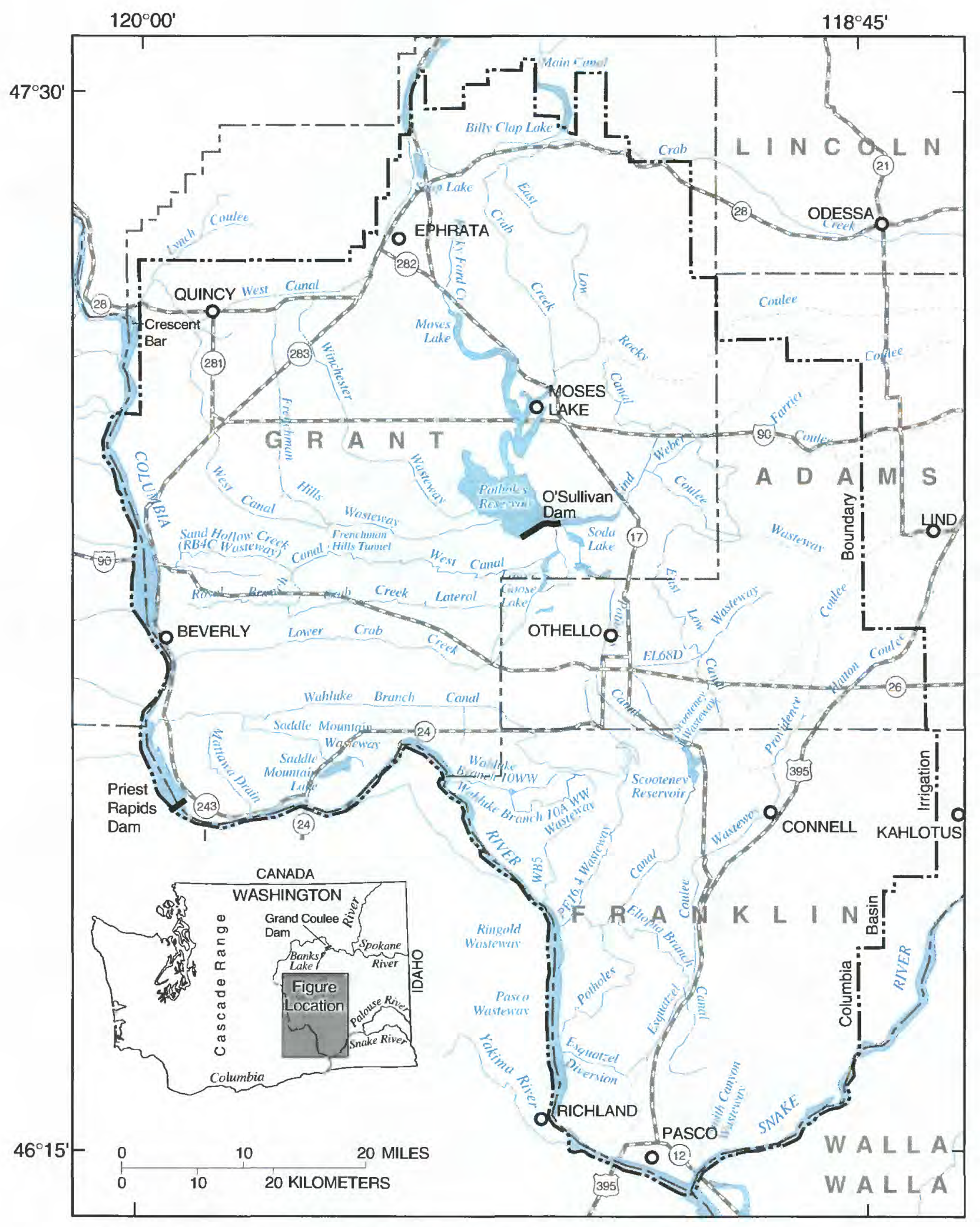

Figure 1.--Location and major features of the Columbia Basin Project in Washington State. 


\section{Acknowledgments}

The authors thank Jenni Cena, USFWS volunteer student, for assisting with all aspects of the biological data collection; David Ames, USFWS volunteer student, for his assistance in assessing water-quality impacts on carp; and James Tabor and Jeffrey Korth, Washington State Department of Wildlife (WDW) biologists, for sharing their knowledge of the biota of the area. Access to private land for data collection provided by irrigation districts and by landowners is also greatly appreciated.

\section{DESCRIPTION OF THE STUDY AREA}

The Columbia Basin Project is a multipurpose development of more than 4,000 square miles on the Columbia Plateau in central Washington and includes all the hydroelectric facilities as well as the agricultural land. Boundaries of the irrigation area and of the irrigation-drainage reconnaissance study area are Billy Clapp Lake on the north, the Columbia and Snake Rivers on the south, and the Columbia River on the west. A line formed by the cities of Odessa, Lind, and Kahlotus is an approximate boundary on the east. The CBP encompasses Grant County, parts of Adams and Franklin Counties, and, to a lesser extent, parts of Lincoln and Walla Walla Counties.

The major source of water for irrigated agriculture in the CBP is Columbia River water held in Franklin D. Roosevelt (FDR) Lake by Grand Coulee Dam. A total of 12 pumping units, each with 65,000 or more horsepower, pump water from FDR Lake into Banks Lake at an average annual rate of approximately $3,600 \mathrm{ft}^{3} / \mathrm{s}$ (Bureau of Reclamation, 1982). Water is then moved from Banks Lake through the irrigation area by numerous siphons, tunnels, canals, wasteways, drains, lakes, coulees, and natural streams. In addition to irrigation, the water imported from FDR Lake provides recreation, wildlife habitat, and in-stream support of aquatic life and fisheries. Small quantities of water are withdrawn for food processing.

The increased quantity of surface water as a result of the irrigation project greatly increased recreational use of the CBP over pre-irrigation recreational use. Five State parks now provide picnicking, swimming, boat launching, and camping facilities. More than 30 facilities on State or Federal land provide access for fishing, hunting, recreational boating, water skiing, and birdwatching. Including the recreational area around Banks Lake, there are over 200,000 acres of land open to public access, and approximately 133,000 acres of lake or reservoir surface.
Prior to the development of the CBP there were 35 lakes; now there are more than 140 lakes, ponds, and reservoirs. The four major reservoirs (Banks Lak:, Billy Clapp Lake, Potholes Reservoir, and Scooteney Reservoir) had more than a million visitors in 1988 (Bureau of Reclamation, 1989). Private lands and undeveloped areas of Federal land also provide water-related recreational activities.

Fishing and hunting are the dominant recreational activities in the CBP. Fishing accounted for the majority of almost 190,000 visits to Columbia National Wildlife Refuge in 1991 (U.S. Fish and Wildlif : Service, 1992). In a 1991 creel survey, more than $42,00 \mathrm{C}$ angling trips were made to Moses Lake during a 9-month period (Jeffrey Korth, Washington State Department of Wildlife, written commun., 1993). A recent survey of 7,000 people conducted by the Washington State Department of Wildlife indicated that Grant County, which includes well over half of the CBP, was one of the most fished counties in the State in 1986 (Big Bend Economic Development Council, 1991). Because the irrigation project $Y$ as greatly increased waterfowl habitat, the Columbia Basir is also one of the most important waterfowl hunting areas in the State (Bureau of Reclamation, 1989).

Five towns in the CBP have populations greater than 2,500: Pasco, Moses Lake, Ephrata, C thello, and Quincy. At the extreme southern end of the study area, Pasco is the largest with a population of about 19,000. Moses Lake, near the center of the study area, is second largest with a population of about 11,000. Irrigated and dryland agriculture, livestock production, and food processing dominate the economic activities.

\section{History}

The Columbia Basin Project began in 1933 with the allocation of funds for the construction of Grand Coulee Dam. The dam and power structures were nearly completed by 1941, but the beginning of World War II postponed completion of the irrigation proiect. In 1943, work on the project resumed with the excavation of the Main Canal. The first development of irrigated land began in 1948 in the southern part of the area with water pumped from the Snake and Columbia Rivers. In the northern part of the area, irrigation water was delivered through the Main Canal system beginning in 1952. Most of the irrigated acreage was developed between 1952 and 1959; some additional acreage was added during the mid-1960's (Bureau of Reclamation, 1989). 
The BR had responsibility for the Columbia Basin Project following the construction of Grand Coulee Dam. In 1969, the operation and maintenance of the basic irrigation system became the responsibility of three irrigation districts. Operation and maintenance responsibilities of Grand Coulee Pumping Plant, Banks Lake, Main Canal, and Potholes Reservoir remain with the BR (Bureau of Reclamation, 1976).

\section{Wildlife and Fisheries}

The irrigation project has both eliminated and improved wildlife habitat. Vast acreage of shrub-steppe habitat was eliminated by conversion to agriculture, or degraded by grazing. However, the increased volume of surface water improved the habitat value of some of the remaining shrub-steppe habitat, and greatly increased the acreage of wetlands and the populations of those species found in or near wetlands. Substantial land in the CBP is managed for wildlife (fig. 2). About 53,400 acres are managed as National Wildlife Refuge land and more than 170,000 acres are owned or managed by the WDW. In addition, an unknown amount of land is managed for wildlife by other agencies, hunting clubs, and private landowners.

The CBP is part of the Pacific Flyway, a major north-south waterfowl migration route. Waterfowl use of the Columbia Basin has increased dramatically because of increased aquatic habitat and food supply from postharvest crop residues created by irrigation (Foster and others, 1984). Although CBP wetlands are used for nesting, brood rearing, and migratory stopover, the most important use by waterfowl is wintering habitat. Wintering waterfowl depend on habitat in the Columbia Basin for about 5 months of the year. Almost 15 percent of wintering waterfowl in 11 western States were in the Columbia Basin during the winter of 1990-91. Annual surveys over the past 15 years indicate that almost a million ducks and about 170,000 Canada geese winter in the Columbia Basin. At certain times of the year, 85 to 90 percent of the mallards in the Pacific Flyway can be found in the Columbia Basin. The northern part of the CBP provides important habitat in mild winters; in cold winters, when open water in the northern part freezes up, the southern part of the CBP usually can provide open-water habitat to waterfowl (John Annear, U.S. Fish and Wildlife Service, Umatilla National Wildlife Refuge, oral commun., 1993). Wasteways that receive drainage from buried tile drains and that flow year around provide some open-water habitat to wintering birds and early spring migrants (Foster and others, 1984).
The many small ponds in the CBP created by increased ground-water levels and seep ige from canals are important waterfowl brood-rearing habitat. Numerous ponds in the sand dunes region around Potholes Reservoir and the lower reaches of Winchester ard Frenchman Hills Wasteways are considered to be the mcat important waterfowl production areas in the Columbia Basin (Foster and others, 1984). The wasteways also provide some broodrearing habitat. Islands in the larger re ervoirs and in Moses Lake are preferred nesting sites for Canada geese.

The aquatic habitat provides food for many fisheating and other aquatic birds. Colonies of western grebes, Clark's grebes, double-crested cormorants, great blue herons, great egrets, ring-billed gulls, Forster's terns, and Caspian terns are found around Potholes Reservoir; colonies of black-crowned night-heron' are found in several areas throughout the CBP. Non-cclonial nesters that use CBP wetlands include American bitterns, pied-billed grebes, black terns, American avocets, black-necked stilts, and red-necked phalaropes. Several spacies of hawks, falcons, eagles, and owls are found in the CBP. Of these species, bald eagles and northern harriers are probably the most dependant on other species that ure wetlands (James Tabor, Washington State Department of Wildlife, oral commun., 1993).

There are several species of special status listed by the USFWS and WDW in the CBP. Pe-egrine falcons apparently are found only during their spring and fall migration; when in the CBP, the falcons prey on waterfowl and shorebirds. Bald eagles are present during all seasons but especially in the winter; the eagles prey on fish and waterfowl. Black terns nest in marshes within the CBP and feed on insects. The Potholes mea low vole, which has not been observed for several decades in the CBP, lives in riparian grasses and reeds. American white pelicans do not breed in the CBP, but increasing numbers of immature and post-breeding birds have been using the Columbia Basin for feeding and resting in the last several years. Sandhill cranes use parts of the Columbia Basin as a staging area and are found in large numbers during their spring and fall migration. Spotted frogs once present in all areas of the State, are no longer fourd in western Washington and are now only sparsely distributed in eastern Washington including the CBP. A complete list of Federal- and State-listed species found in the CBP is shown in table 1.

Twenty-eight game and 13 non-game fish species are known to be present. Four species of a adromous fish use reaches of the Columbia River both up:tream and down 


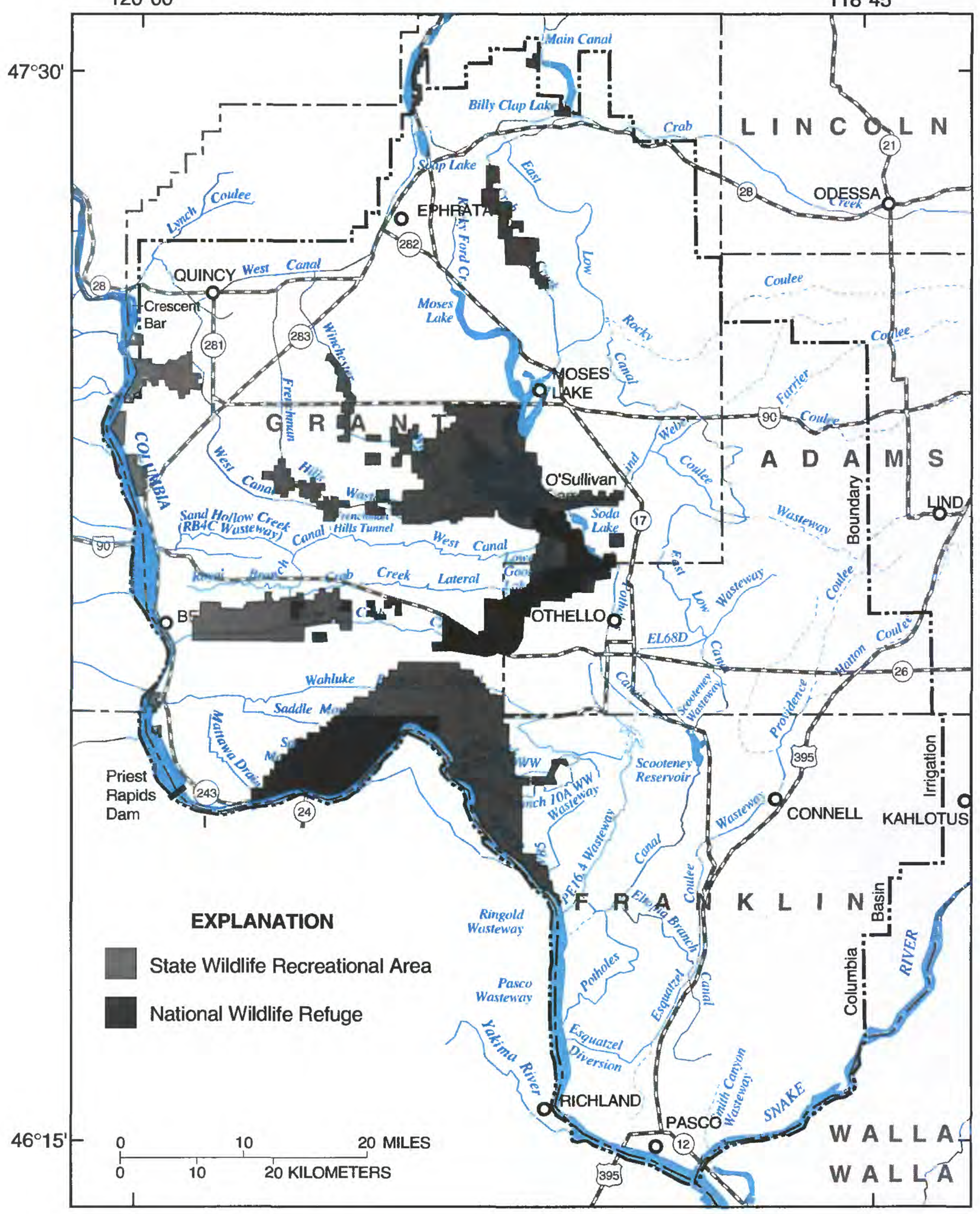

Figure 2.--Federal National Wildlife Refuges and State Wildlife areas in the Columbia Basin Project. 
Table 1.-- Common and scientific names and endangerment status of species in or near wetlands and shrub-steppe habitat within the Columbia Basin Project, Washington

[FT, Federal threatened; FC, Federal candidate; FE, Federal endangered; ST, State threatened; SC, State candidate; SE, State endangered; SM, State monitor; SS, State sensitive; compiled from U.S. Fish and Wildlife Service files, Moses Lake, Washington]

Common name

Scientific name

Status

\begin{tabular}{|c|c|c|}
\hline Birds & & \\
\hline American White Pelican & Pelecanus erythrorhynchos & SE \\
\hline Ash-throated Flycatcher & Myiarchus cinerascens & SM \\
\hline Bald Eagle & Haliaeetus leucocephalus & FT, ST \\
\hline Black-crowned Night-heron & Nycticorax nycticorax & SM \\
\hline Black-necked Stilt & Himantopus mexicanus & SM \\
\hline Black tern & Chlidonius niger & $\mathrm{FC}$ \\
\hline Burrowing Owl & Athene cunicularia & SC \\
\hline Common Loon & Gavia immer & SC \\
\hline Ferruginous Hawk & Buteo regalis & FC, ST \\
\hline Forster's Tern & Sterna forsteri & SM \\
\hline Golden Eagle & Aquila chrysaetos & SC \\
\hline Grasshopper Sparrow & Ammodramus savannarum & SM \\
\hline Great Blue Heron & Ardea herodias & SM \\
\hline Loggerhead Shrike & Lanius ludovicianus & FC, SC \\
\hline Long-billed Curlew & Numenius americanus & SM \\
\hline Osprey & Pandion haliaetus & SM \\
\hline Peregrine Falcon & Falco peregrinus & FE, SE \\
\hline Prairie Falcon & Falco mexicanus & SM \\
\hline Sage Sparrow & Amphispiza belli & SC \\
\hline Sage Thrasher & Oreoscoptes montanus & $\mathrm{SC}$ \\
\hline Sandhill Crane & Grus canadensis & SE \\
\hline Swainson's Hawk & Buteo swainsoni & SC \\
\hline Western Grebe & Aechmophorus occidentalis & SM \\
\hline Mammals & & \\
\hline Merriam's Shrew & Sorex merriami & $\mathrm{SC}$ \\
\hline Northern Grasshopper Mouse & Onychomys leucogaster & SM \\
\hline Ord's Kangaroo Rat & Dipidomys ordii & SM \\
\hline Potholes Meadow Vole & Microtus pennsylvanicus kinkaid & $\mathrm{FC}, \mathrm{SM}$ \\
\hline Pygmy Rabbit & Brachylagus idahoensis & FC, ST \\
\hline Washington Ground Squirrel & Spermophilus washingtoni & SM \\
\hline Reptiles & & \\
\hline Desert Night Snake & Hypsiglena torquata & SM \\
\hline Desert Striped Whipsnake & Masticophis taeniatus & SC \\
\hline Amphibians & & \\
\hline Desert Tiger Salamander & Ambystoma tigrinum & SM \\
\hline Spotted Frog & Rana pretiosa & FC, SC \\
\hline Invertebrates & & \\
\hline Yuma Skipper & Ochlodes yuma & $\mathrm{SC}$ \\
\hline Plants & & \\
\hline Bristly Cryptantha & Cryptantha interrupta & SS \\
\hline Columbia Yellowcress & Rorripa columbiae & FC, SE \\
\hline Dwarf Evening Primrose & Oenothera pygmaea & SS \\
\hline Gray Cryptantha & Cryptantha leucophaea & SS \\
\hline Northern Wormwood & Artemisia campestris wormskioldii & FC, SE \\
\hline Snake Canyon Desert Parsley & Lomatium serpentinum & SS \\
\hline
\end{tabular}


stream of the CBP. Fall chinook salmon spawn in the Hanford Reach of the Columbia River, which borders the southern half of the CBP area. Occasionally, fall chinook salmon inhabit the lower reaches of Crab Creek and spawn in the lower reaches of Sand Hollow Creek (also known as RB4C Wasteway).

No commercial fisheries currently exist in the CBP, although carp were occasionally harvested from Moses Lake between 1917 and 1977 (Big Bend Economic Development Council, 1991). The recreational fishery, however, is extensive. Potholes Reservoir is considered to have the most diverse and well-used fishery in the Columbia Basin (Bureau of Reclamation, 1989). Most of the seep lakes managed by the WDW are stocked with hatchery-reared rainbow trout and are periodically rehabilitated to remove undesirable species.

Moses Lake has experienced a severe decline in its recreational fishery in the last decade. In the 1960's and 1970 's, the lake was the premier black crappie and bluegill fishery in Washington and was also an exceptional bass fishery. Comparison of 1983 and 1991 creel surveys indicated substantial declines in harvest of these species and of yellow perch as well. The number of angler visits declined and the community lost a significant contribution to the local economy. Although numerous theories have been proposed, the reason for the decline in Moses Lake fishery has not been determined (Jeffery Korth, Washington Department of Wildlife, written commun., 1993).

\section{Climate}

The climate of the CBP is semiarid to arid with hot, dry summers and moderately cold winters. The Cascade Range strongly affects the climate of the area because it acts as a precipitation barrier and captures most of the heavy maritime precipitation that moves into the State from the southwest. Precipitation is about 6 to 10 inches per year and evapotranspiration is about 15 inches per year under present irrigation conditions (Bauer and Vaccaro, 1990). Typically, 85 percent of the total annual precipitation falls from October through May; nearly 40 percent falls during winter from November through January. Winter snowfall is from 8 to 20 inches (H. H. Bauer, U.S. Geological Survey, written commun., 1989). Normal precipitation at Ephrata averages 7.3 inches per year (National Oceanic and Atmospheric Administration, 1982). Before this study, however, annual precipitation was from 0.4 to 3.0 inches below normal for all but 3 years during 1985-91. In 1991 and 1992 during the study, the yearly totals of precipitation were, respectively, 0.4 and
2.69 inches above normal. In November 1991 and July 1992, when water and bottom-sediment samples were collected, monthly precipitation totaled about 1.6 and 1.7 inches, respectively, (fig. 3), which was about 0.7 inches above normal for November and 1.4 inches above normal for July.

The Cascade Range also directs cold arctic air southward into the CBP during winter and hot, dry desert air northward during summer. January air temperature typically averages about $20^{\circ} \mathrm{F}$ (degrees Fahrenheit) and July air temperature averages about $91^{\mathrm{C}} \mathrm{F}$. Extreme temperatures of $22^{\circ} \mathrm{F}$ below zero and $113^{\circ} \mathrm{F}$ have been recorded in the CBP (U.S. Bureau of Reclamation, 1982).

\section{Geohydrology}

The Columbia Plateau was formed between 6 and 16.5 million years ago by the extrusion of basalt lava from northwest-trending vents located in the central and southeastern parts of the Plateau (Drost and others, 1990). Belonging to the Columbia River Basal: Group, these massive flows are estimated at more than 14,000 feet thick in the deepest part of the basin, near Pasco. Subsequent tectonic action warped the region into a broad synclinal basin with several subbasins formed by locally steeper folding and faulting (Tanaka and others 1974). Quaternary-aged (from 1.6 million years ago to the present) deposits of glacial outwash consisting mostly of sand and gravel partially filled these subbasins. Parts of the CBP have a covering of Pleistocene-aged loess, a wind-deposited silt thought to be derived largely from an older sedimentary formation that makes up part of the Columbia River Basalt Group (Walters and Grolier, 1960). Sand dunes (such as those near Potholes Reservoir) and the loess deposits continue to be extensively reworked by wind (Walters and Grolier, 1960).

The Columbia River Basalt Group and the overlying deposits of unconsolidated sediment are the two principal geohydrologic units in the CBP. Becaure of its fractured, jointed nature, the basalt is generally casable of yielding large quantities of water to wells and is a principal source of ground water for agricultural, municizal, industrial, and domestic use. In areas of ground-water withdrawals for irrigation, water levels have declined lozally as much as 200 feet (Drost and others, 1990). In other areas where imported surface water is used for irrigation, ground-water levels have risen to the extent that the water is at land surface. 


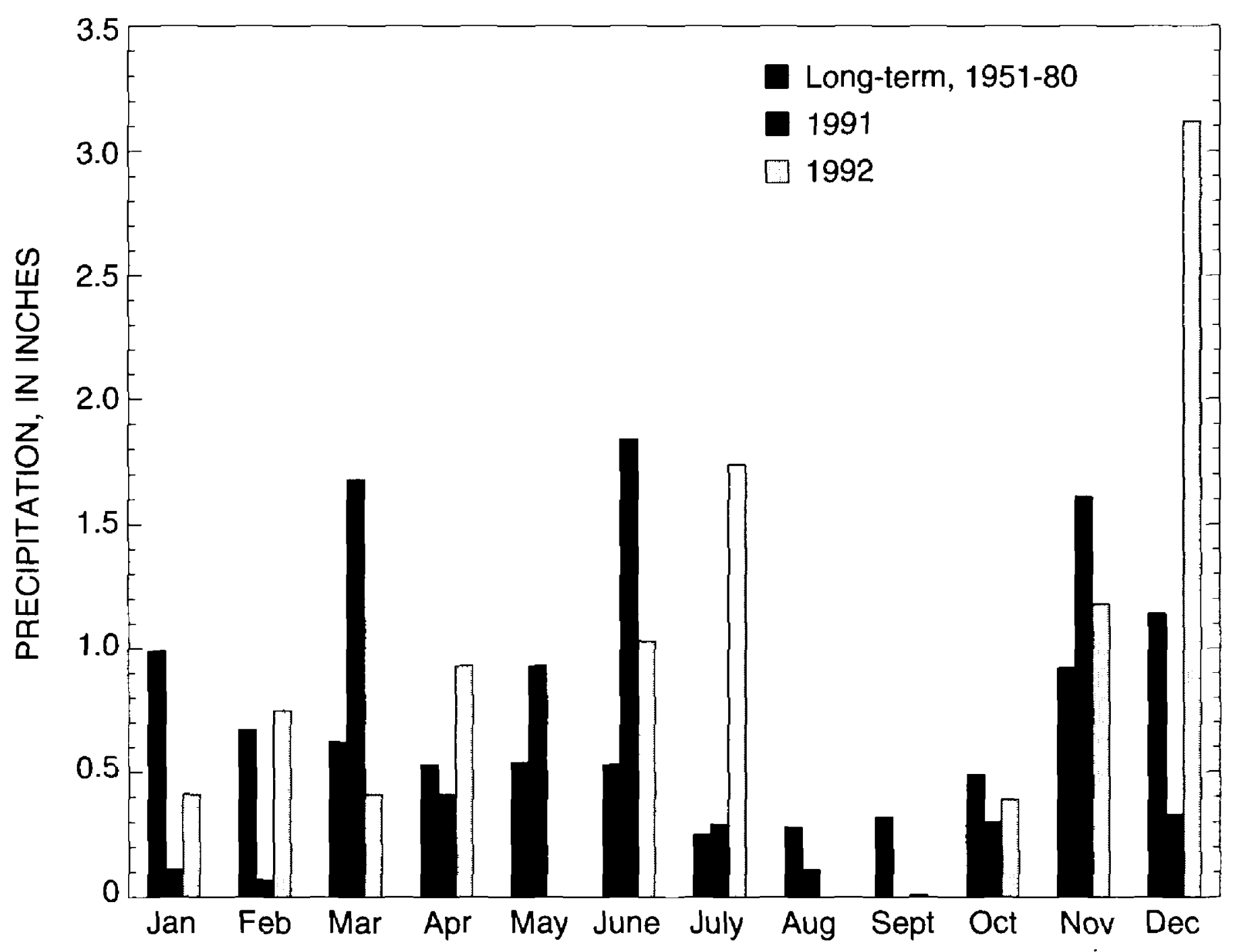

Figure 3.--Long-term average precipitation (1951-80) and monthly precipitation for the years 1991 and 1992 at Ephrata, Washington. 


\section{Soils and Agriculture}

The wind-blown soil known as loess accumulated on the eastern uplands of the CBP. The loess is a fine-grained sandy loam and silt loam that ranges from brown to dark brown in color. Loess soils are particularly suitable for dryland farming because they are water-retentive, easily tilled, and fertile (Bureau of Reclamation, 1976).

After the Pleistocene epoch, wind-blown sand and silt (derived from the stream-deposited materials originating from outside the $\mathrm{CBP}$ ) were mixed with volcanic ash from Cascade Range volcanos and deposited over the CBP (Bureau of Reclamation, 1976). This soil type makes up the agriculturally useful soils in the northern and western parts of the CBP. They are gray to light brown, low in organic matter, and variable in crop-production capability (Bureau of Reclamation, 1976). Caliche, a cement-like calcium carbonate deposit, underlies the windblown soils in some areas of the CBP and forms a nearly impermeable layer in the soil horizons. Caliche is found mainly in the west-central area on the south slope of Frenchman Hills and along the Columbia River north of Pasco (E. L. Skinner and others, U.S. Geological Survey, written commun., October 1989).

About 1.1 million acres of approximately 2.5 million acres of land in the CBP is irrigable; the remainder is channeled scabland and rangeland (E. L. Skinner and others, U.S. Geological Survey, written commun., October 1989). In 1991, farmers irrigated about 575,000 acres of authorized irrigable land with surface water, and in 1992, about 580,000 acres (Alan Schram, Bureau of Reclamation, written commun., April 1992 and 1993) (fig. 4). The major irrigated crops are alfalfa ( 30 percent), wheat (15 percent), corn ( 9 percent), potatoes ( 7 percent), beans ( 6 percent), and peas ( 6 percent). A wide variety of crops makes up the remaining 27 percent: vegetables, grain, hay seeds, orchards, mint, asparagus, and pasture (E. L. Skinner and others, U.S. Geological Survey, written commun., October 1989).

Insecticides, herbicides, and fungicides are used in agricultural practices and maintenance of the irrigation system. Pesticides commonly used by the farmers in the CBP are listed in table 2 (E. L. Skinner, U.S. Geological Survey, written commun., October 1989; K.E. Greene, U.S. Geological Survey, written commun., March 1993). In Grant County during 1982, approximately 1,100 tons of herbicides and 670 tons of insecticides were applied to agricultural land (U.S. Department of Commerce, 1982). In general, herbicide application is about $10 \mathrm{lbs} / \mathrm{acre}$ (pounds per acre); insecticide application is about
$12 \mathrm{lbs} / \mathrm{acre}$ (K. E. Greene, U.S. Geological Survey, written commun., March 1993). The Grant County Mosquito Control District in 1991 and 1992 was permitted to use the insecticides methoxychlor, Scourge, and Cythion (malathion) for mosquito control.

Herbicides used on the irrigation system include 2,4-D (2,4-dichloro-phenoxyacetic acid), copper sulfate, acrolein, and occasionally xylene. Herbicides are applied during the irrigation season to control algal and vascular plant growth in irrigation channels and thereby maintain flow velocity and capacity at design depths. Herbicides, particularly 2,4-D, are also used on canal banks to control noxious weed species, to reduce habitat for rodents, and to reduce the spreading of weed seeds to cultivated fields. 2,4-D is applied at least once and sometimes twice a year at a rate of 1.5 to $2.5 \mathrm{lbs} /$ acre (Bureau of Reclamation, 1976). Copper sulfate is used to control filamentous green algae in canals and channels. Most waterways are treated at several locations and at several times during the irrigation season. Generally, one-third pound of copper sulfate per $\mathrm{ft}^{3} / \mathrm{s}$ of water is applied, which results in a concentration of about $5 \mathrm{mg} / \mathrm{L}$ of copper sulfate pentahydrate (Bureau of Reclamation, 1976). Coprecipitation of copper by oxides or adsorption on mineral surfaces (Hem, 1989) could cause a buildup of copper in bottom sediments. Acrolein is used primarily in the large canals and laterals where the flow is greater than $150 \mathrm{ft}^{3} / \mathrm{s}$. East Low Canal, West Canal, Potholes Canal, and Wahluke Branch Canal are treated with acrolein at several points. Acrolein is usually applied five or six times a year during the irrigation season, beginning in late May and continuing at 3- to 5-week intervals until late September. The general application rate is about $0.1 \mathrm{mg} / \mathrm{L}$ over a period of 48 hours, or 0.167 gallons of acrolein per $\mathrm{ft}^{3} / \mathrm{s}$ of water (Bureau of Reclamation, 1976). Acrolein volatilizes at rates dependent on water temperature, $\mathrm{pH}$, and total dissolved-solids content (Magna Corporation, 1984).

At the end of irrigation season when the channels are drained for winter, sodium trichloroacetic acid (TCA) is applied to channels containing reed canarygrass, an undesirable grass species. The Bureau of Reclamation (1976) reported that although most of the TCA degrades during the winter, a small amount (about $0.1 \mathrm{mg} / \mathrm{L}$ ) is in the water during the first few hours of channel flow at the start of the next irrigation season.

Fertilizers containing nitrogen and phosphorus are used in the CBP. During 1987 in Grant County alone, about 28,000 tons of nitrogen and 8,400 tons of phosphorus were applied to agricultural land (G. J. Fletcher, West Virginia University, written commun., 1991). Nitrogen 


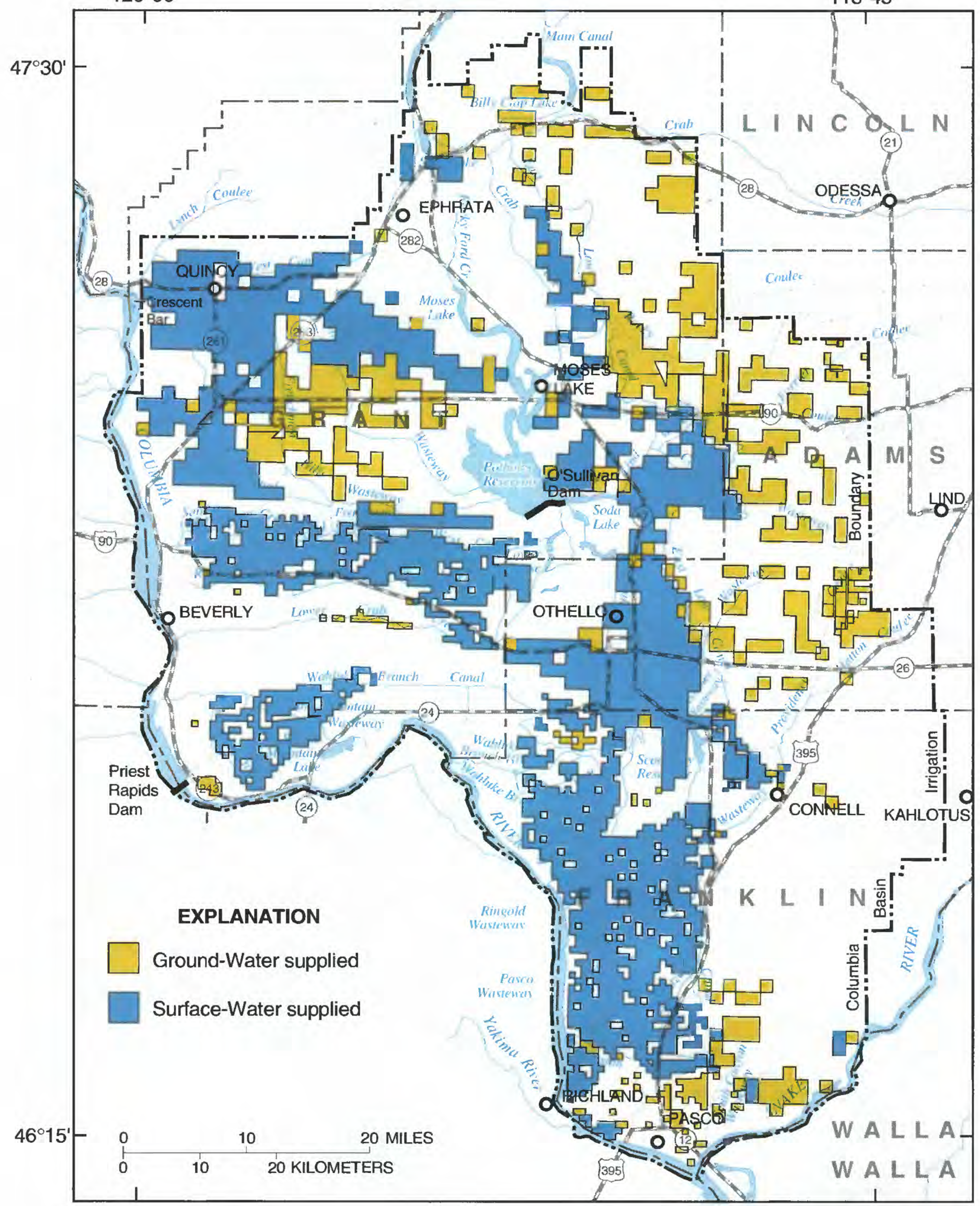

Figure 4.--Distribution of the applications of surface water and ground water for irrigation (Modified from Bauer and Vaccaro, 1990). 
Table 2.-Pesticides commonly used on farms in the Columbia Basin Project

\begin{tabular}{|c|c|}
\hline Herbicides/Fungicides & Insecticides \\
\hline $\begin{array}{l}\text { Common name, and } \\
\text { a (trade name) }\end{array}$ & $\begin{array}{l}\text { Common name, and } \\
\text { a (trade name) }\end{array}$ \\
\hline $2,4-\mathrm{D}$ & Aldicarb (Temik) \\
\hline Alachlor & Azinphos-methyl (Guthion) \\
\hline Atrazine & Carbaryl (Sevin) \\
\hline Benomyl & Chloropicrin (Telone C); also a fungicide \\
\hline Bromoxynil & Chlorpyrifos (Lorsban) \\
\hline Chlorpropham (Chloro-IPC) & Diazinon \\
\hline Chlorsulfuron (Glean) & Dimethoate (Cygon) \\
\hline Chlorothalonil (Bravo) & Disulfoton (Disyston) \\
\hline Cycloate (RoNeet) & Endosulfan (Thiodan) \\
\hline DCPA (Dacthal) & Ethoprop (Mocap) \\
\hline Dicamba (Banvel) & Fluvalinate (Spur) \\
\hline Dichlobenil (Casoron) & Malathion (Cythion) \\
\hline Dinoseb (DiNitro) & Methamidophos (Monitor) \\
\hline Diquat & Parathion \\
\hline Diuron (Karmex) & Phorate (Thimet, Rampart) \\
\hline EPTC (Eptam) & Phosmet \\
\hline Ethalfluralin (Sonalan) & Propargite (Omite) \\
\hline \multicolumn{2}{|l|}{ Glyphosate (Roundup) } \\
\hline \multicolumn{2}{|l|}{ IPC or propham (Ban-Hoe) } \\
\hline \multicolumn{2}{|l|}{ Mancozeb } \\
\hline \multicolumn{2}{|l|}{ Metalochlor } \\
\hline \multicolumn{2}{|l|}{ Metam sodium } \\
\hline \multicolumn{2}{|l|}{ Metribuzin } \\
\hline \multicolumn{2}{|l|}{ Oryzalin (Surflan) } \\
\hline \multicolumn{2}{|l|}{ Pendimethalin (Prowl) } \\
\hline \multicolumn{2}{|l|}{ Picloram (Tordon) } \\
\hline \multicolumn{2}{|l|}{ Sulfur } \\
\hline \multicolumn{2}{|l|}{ Terbutrin } \\
\hline \multicolumn{2}{|l|}{ Thiabendazole (TBZ) } \\
\hline \multicolumn{2}{|l|}{ Triallate (Far-Go) } \\
\hline \multicolumn{2}{|l|}{ Tribenuron methyl } \\
\hline \multicolumn{2}{|l|}{ Trifluralin (Treflan) } \\
\hline Vernolate (Vernam) & \\
\hline
\end{tabular}


was applied at a rate of about $30 \mathrm{lbs} / \mathrm{acre}$ and phosphorus at a rate of about $10 \mathrm{lbs} / \mathrm{acre}$ (K. E. Greene, U.S. Geological Survey, written commun., March 1993).

\section{Surface-Water Hydrology}

Before importation of Columbia River water and irrigation, Crab Creek and Rocky Ford Creek were the two perennial streams in the study area. Other natural channels were dry except during snowmelt and rainstorm runoff. Moses Lake, the largest natural lake in the area, formed when a sand dune drifted across and impounded Crab Creek (Walters and Grolier, 1960). Other small lakes and wetlands formed in fiat-bottomed coulees and in areas near the Columbia River. Esquatzel Coulee, the principal drainage in the southern part of the CBP, was dry most of the year. During periods of snowmelt and runoff, Esquatzel Coulee flooded because it had no surface outlet. The flood seeped into the ground in a pothole area near Pasco and eventually entered the Columbia River.

After surface-water importation and irrigation began in the early 1950's, stream discharge in Crab Creek increased dramatically with additional water from wasteways and ground-water recharge (fig. 5a). Stream discharge also increased in Rocky Ford Creek but declined after about 1960 (fig. 5b). Additional hydrologic changes occurred as a result of the irrigation project. The impoundment of Crab Creek by O'Sullivan Dam formed Potholes Reservoir. Moses Lake received inflow from irrigation return flow, ground-water seepage, and canal water originating from the Columbia River. Esquatzel Coulee was incorporated into the return-flow system as a wasteway, which made it a perennial stream carrying return flows to the Columbia River. Other natural channels, normally dry most of the year, were converted into wasteways to handle irrigation return flows. Throughout the CBP, new lakes and wetlands formed and the surface area of the few existing ones increased.

Because of their long-term streamflow records, Crab Creek near Beverly and Rocky Ford Creek near Ephrata were chosen to represent hydrologic conditions of the surface-water system during the 1991-92 study. The hydrograph (fig. 5a) for Crab Creek near Beverly indicates that stream discharge during the study was typical of the flow regime since the late 1970's. Also, average discharges in Crab Creek during the sample-collection months were not much different from 1970-93 mean monthly discharges (fig. 6). In Rocky Ford Creek, however, measurements indicate that 1991-92 discharges were below long-term averages, probably because of several years of below-normal precipitation in eastern Washington. Discharge during 1991 in Rocky Ford Creek averaged $42.5 \mathrm{ft}^{3} / \mathrm{s}$ compared with $73.7 \mathrm{ft}^{3} / \mathrm{s}$ for the period of record (1942-91).

\section{Irrigation Delivery System}

The principal features of the irrigation delivery system are Grand Coulee Dam and FDP Lake, Banks Lake, Billy Clapp Lake, Potholes Reservoir, and the canals: Main, West, East Low, Potholes, Wahluke Branch, and Eltopia Branch (fig. 7). About 2.6 million acre-feet of water are pumped annually from FD $^{\circ}$ Lake into Banks Lake, an equalization and storage re ervoir of water for irrigation (Bureau of Reclamation, 1982). Usually, water is released for irrigation from early March to late October. From Banks Lake, water moves thrcugh Main Canal and Billy Clapp Lake. Below the dam th at forms Billy Clapp Lake, Main Canal divides into West Canal and East Low Canal. West Canal delivers about 1.4 million acre-feet which is used to irrigate about 206,000 acres in the northwestern part of the CBP. In the northeastern part, East Low Canal delivers about 1.2 million acre-feet, which is used to irrigate about 165,000 acres.

The hydrograph for Main Canzl below Billy Clapp Lake (fig. 8a) reflects the long-term controlled discharge (adjusted for the number of acres irrigated in a particular year) during the irrigation season. After declining slightly during the 1960's, the adjusted avers ge annual discharges have been relatively constant since the early 1970's. Monthly average discharges during April, May, September, and October were greater in 1991 and 1992 than was typical of past years (1970-92) (fig. 8b).

Potholes Reservoir collects excess canal water and return-flow water from irrigated land in the northern part of the CBP for reuse in the southern part. From Potholes Reservoir, Potholes Canal delivers un to 1.7 million acrefeet of water to irrigate about 204,0C? acres. Two major canals, Wahluke Branch Canal and F'topia Branch Canal, divert water out of Potholes Canal to the southwestern and southeastern parts of the CBP, respertively.

\section{Irrigation Return-Flow System}

Wasteways carry a mixture of unused water from the operation of the canals and laterals and used water from crop irrigation that is returned through surface and subsurface drains. Many natural drainage channels were 


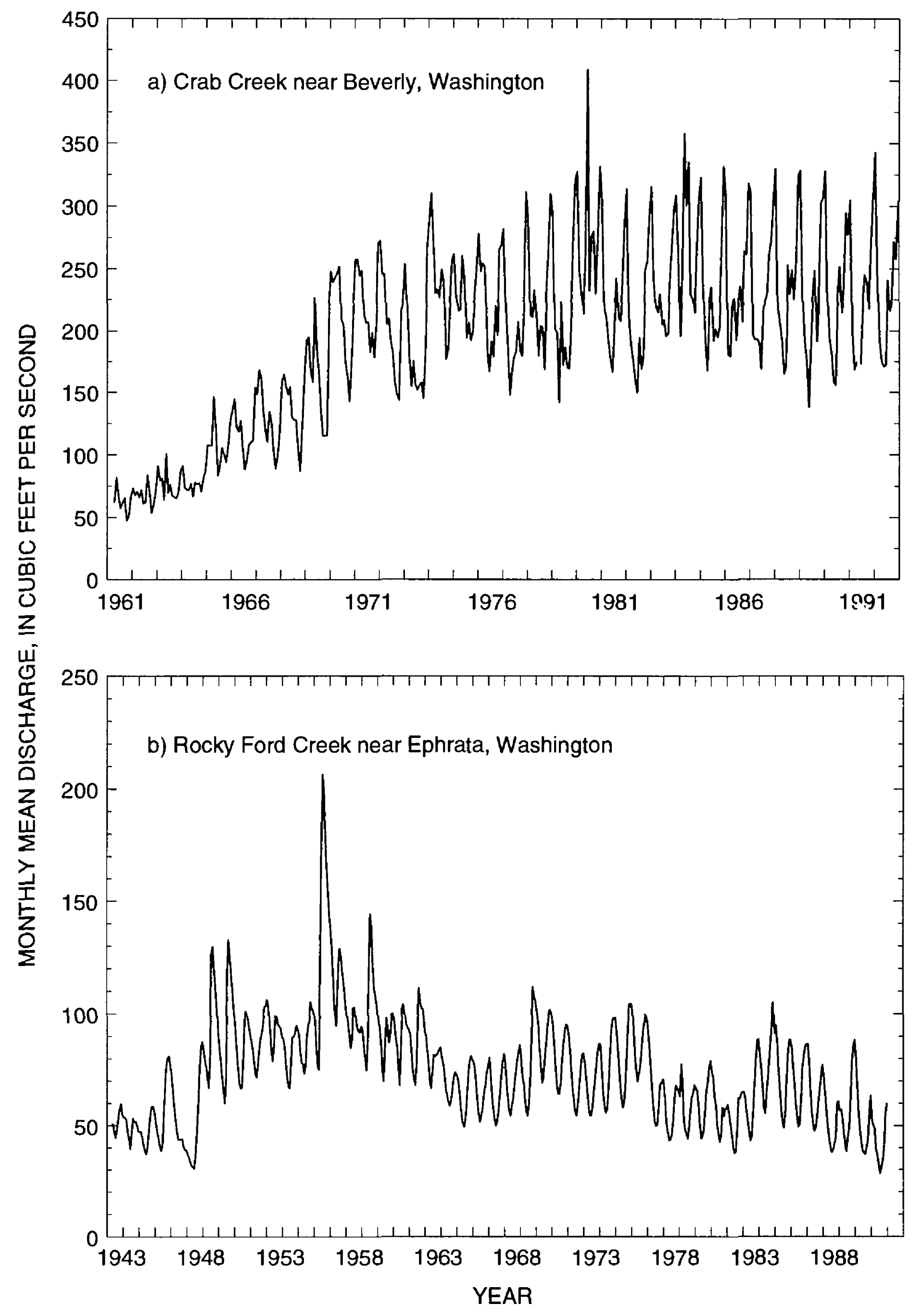

Figure 5.--Monthly mean discharge for a) Crab Creek near Beverly, Washington and b) Rocky Ford Creek near Ephrata, Washington. 


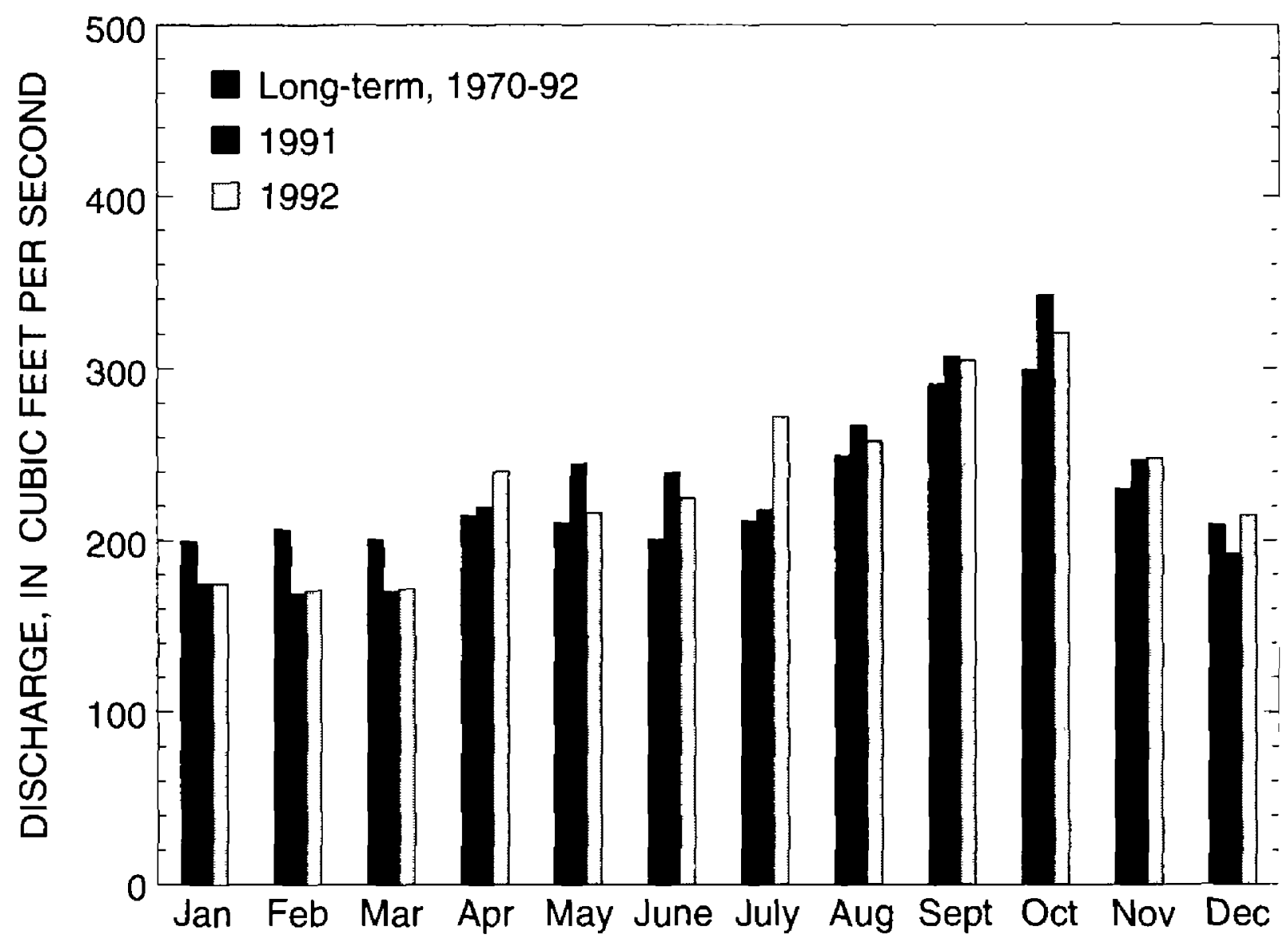

Figure 6.--Long-term (1970-92) mean monthly discharges in Crab Creek nee $r$ Beverly, and the monthly mean discharges during calendar years 1991 and 1992. 


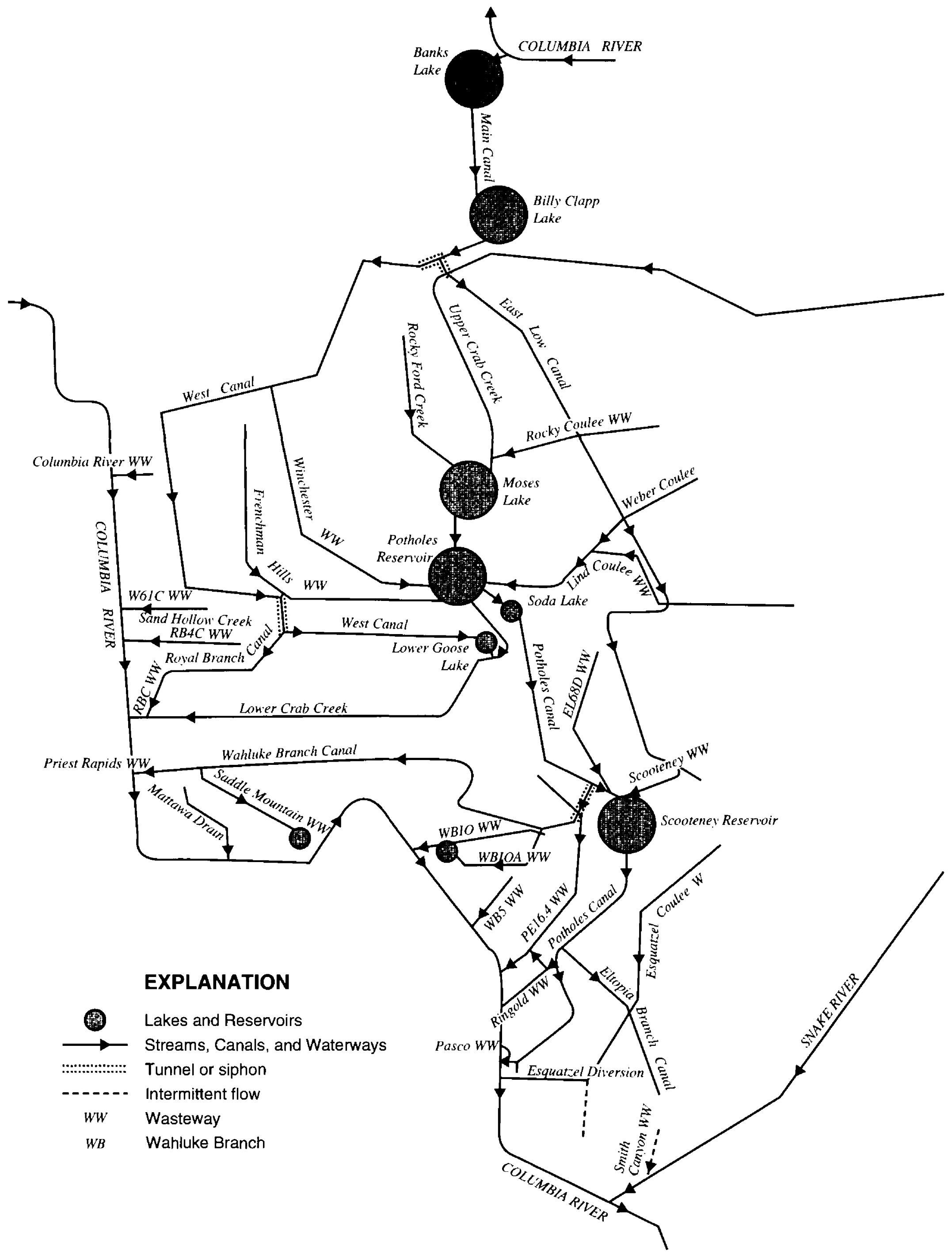

Figure 7.--Schematic diagram of water movement through the Columbia Basin Project and the principal reservoirs and lakes. 


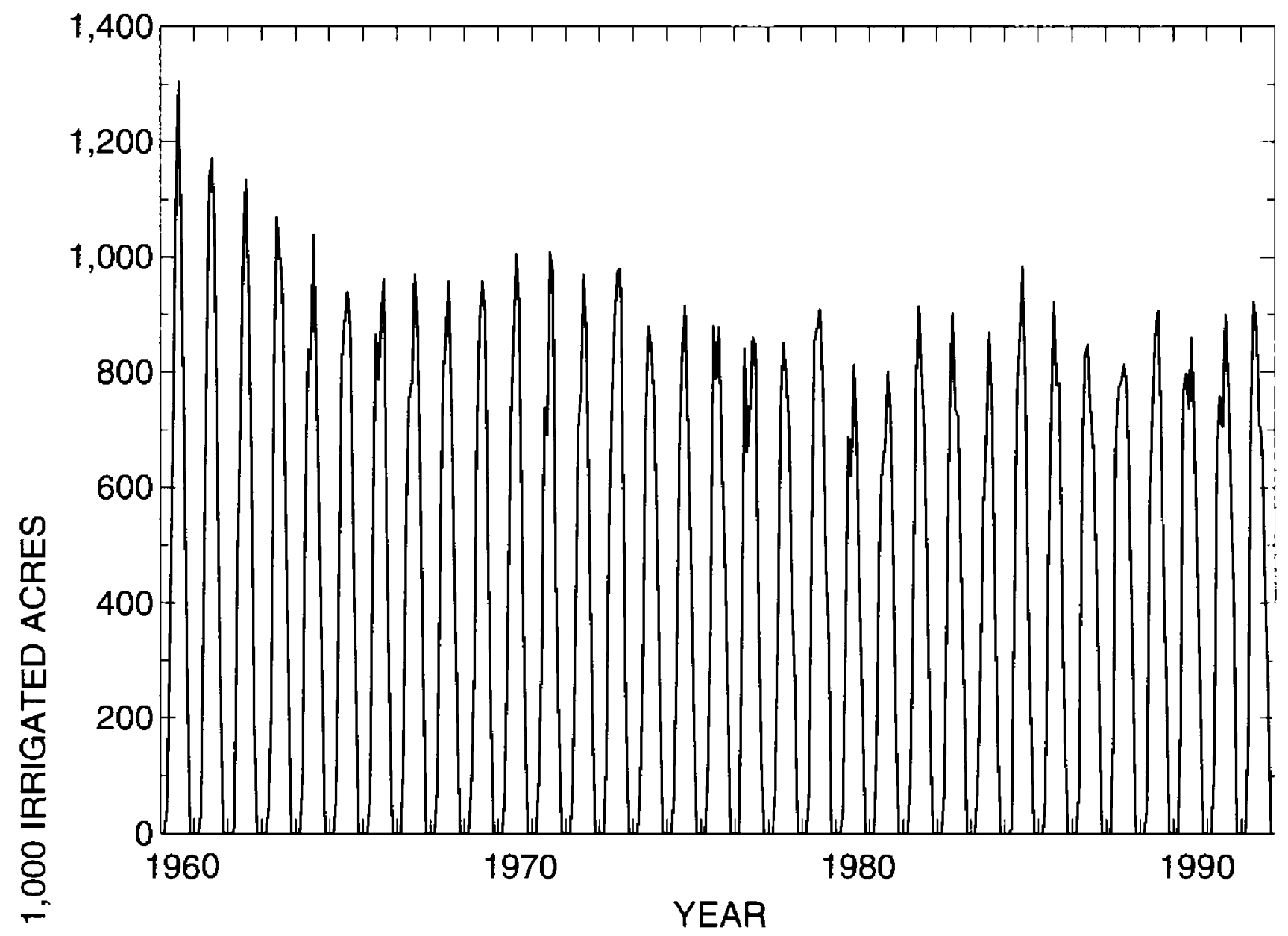

Figure 8a.--Adjusted monthly mean discharge in Main Canal below Billy Clasp $\sim \quad$ Lake for the period 1960-92.

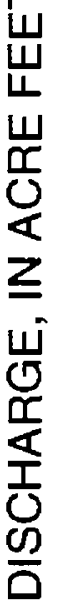

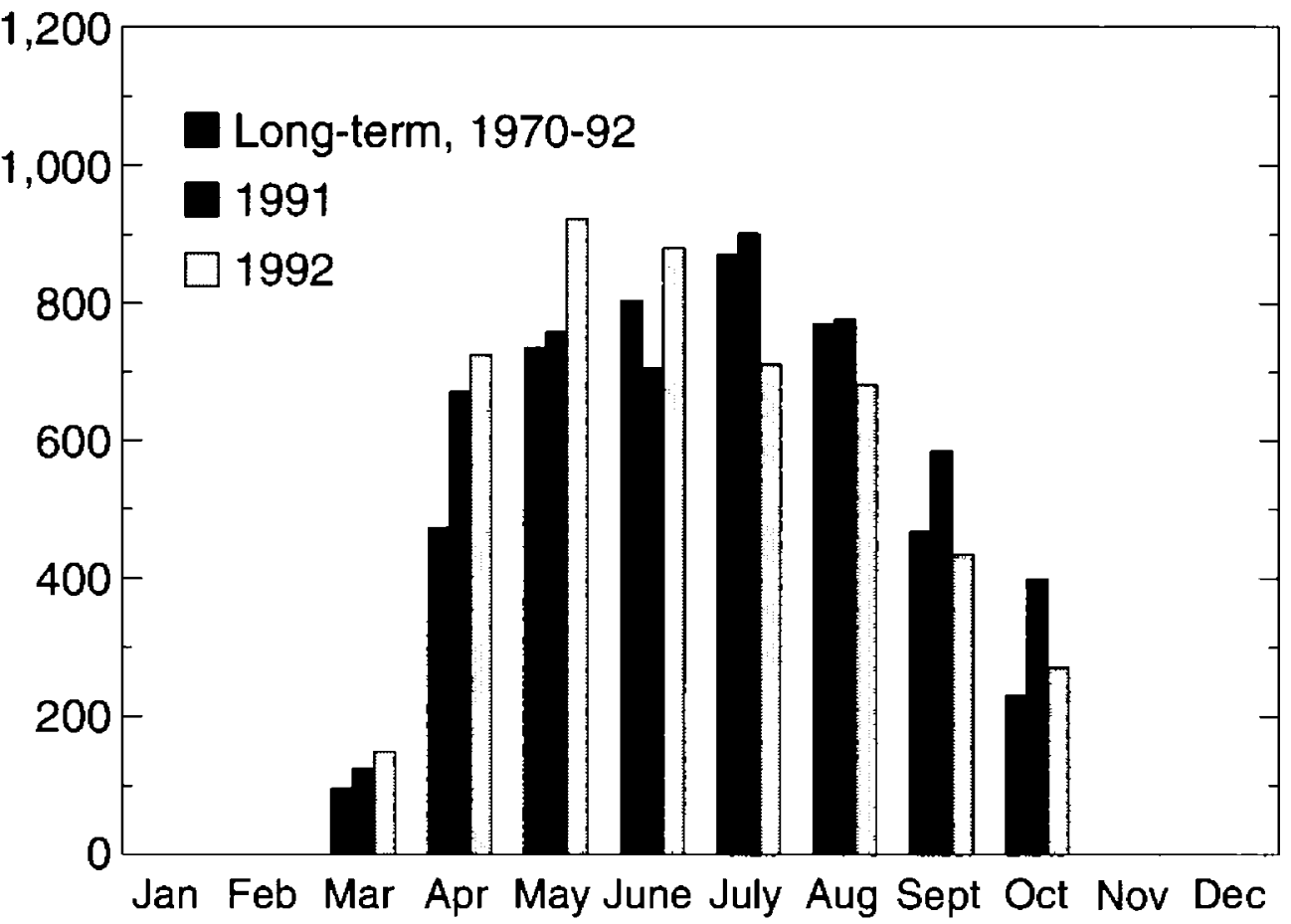

Figure 8b.--Adjusted mean monthly discharge in Main Canal below Billy Clapp Lake for the period 1970-92 and the adjusted monthly mean discharges for calendar years 1991 and 1992. 
incorporated into the return-flow system after irrigation began, some of which were partially lined with concrete. The discussion of the CBP wasteway, and irrigation return-flow system can be divided into three areas: northern, central, and southern.

In the northwestern part of the CBP, land irrigated by the West Canal system is drained primarily by Winchester and Frenchman Hills Wasteways, which empty into the west arm of Potholes Reservoir (fig. 7). Some small wasteways along the western margin discharge directly into the Columbia River. Land in the northeastern part of the CBP, irrigated by the East Low Canal system, is drained by Lind Coulee Wasteway system, which discharges into the east arm of Potholes Reservoir.

Near the center of the CBP, West Canal passes through Frenchman Hills in a siphon tunnel. Beyond the tunnel, some West Canal water is diverted into Royal Branch Canal, but the remainder flows into Lower Goose Lake. Lower Crab Creek, which continues out of Lower Goose Lake, carries return flow from irrigated land between Frenchman Hills and Saddle Mountains to the Columbia River. Return flows in Sand Hollow Creek discharge into the Columbia River. In the east-central part of the CBP, Scooteney Reservoir collects water from Scooteney Wasteway (which receives excess water from East Low Canal) and EL68D Wasteway.

Land in the southern CBP irrigated by the Potholes Canal system is drained by several major wasteways. Pasco Wasteway, PE16.4 Wasteway, and the Wahluke Branch Canal wasteway system all discharge into the Columbia River. Smith Canyon Wasteway drains land irrigated by the Eltopia Branch Canal and intermittently discharges into the Snake River. Esquatzel Coulee Wasteway drains about 480 square miles of the southern CBP and discharges into the Columbia River through the Esquatzel Diversion.

Total return flow to the Columbia River between Crescent Bar (just east of Quincy) and Pasco averages about $550 \mathrm{ft}^{3} / \mathrm{s}$. Although irrigation return flow constitutes nearly 100 percent of the water in the southern CBP wasteways, the wasteways contribute only about 0.5 percent of the average discharge $\left(120,800 \mathrm{ft}^{3} / \mathrm{s}\right)$ in the Columbia River at Priest Rapids Dam (Bureau of Reclamation, 1976).

To protect the fields from rising ground-water levels caused by the importation of Columbia River water, construction of subsurface tile drainage systems began in 1961. The tile systems drain areas from several hundred to more than 2,000 acres and discharge into open wasteways or canals. In 1976, about 200,00 irrigated acres were identified as eventually requiring subsurface drainage systems (Bureau of Reclamation, 1976). Approximately 103,000 acres located primarily in the Quincy and Othello areas now have subsurface tile drainage systems (K. E. Greene, U.S. Geological Survey: written commun., March 1993).

\section{PREVIOUS STUDIES}

Investigations in the CBP and adjacent areas of the Columbia Basin included studies of geohydrology, quantity and quality of surface and ground water, and chemical contaminants in bottom sediment and in biota. These studies provide some background information and data about water quality in CBP irrigation v'asteways, return flows, and reservoirs. Other studies fozused on pesticide residues in fish and bottom sediment and provide information about environmental contamination.

The BR monitored selected water-quality constituents at several sites for a number of years. In 1982, the BR evaluated and summarized these data collected from canals, wasteways, wells, tile drains, and the Columbia River. As water moves from FDR Lake through the CBP system, the use and reuse of water for irrigation generally degrades surface-water and ground-water quality through increased salinity and nutrient concentrations (Bureau of Reclamation, 1982). Potholes Reservcir alleviates some surface-water-quality problems in the central part of the $\mathrm{CBP}$ by stripping nitrogen and phosphorus from the water through plant growth and sedimentation. Some domestic wells in the southern part of the CBP, however, were found to have large concentrations of nitrite-plus-nitrate nitrogen (Bureau of Reclamation, 1982; Turney, 1986; Drost and others, 1989).

Classified as hypereutrophic in th: late 1970's, Moses Lake has been monitored for water-quality changes resulting from two major restoration m:asures--dilution and sewage diversion (Welch and others, 1990). Dilution water has helped reduce blue-green algae (Cyanobacteria) blooms by lowering water temperature and by flushing algae from the lake (Bureau of Reclam?tion, 1989). In 1982, the Moses Lake Clean Lake Project inventoried the sources of nitrogen and phosphorus in the lake watershed. This was the foundation of an 8-year study to evaluate irrigation water-management strate zies designed to further protect the lake by reducing nutrient loads to Moses Lake (Bain, 1990). Bain (1990، determined that 
the Crab Creek and Rocky Ford Creek drainages were major sources of nitrogen, and that Rocky Ford Creek was a major contributor of phosphorus to the lake.

From 1974-78, the BR investigated pesticides in water and bottom sediment in the CBP. Pesticide concentrations were less than $1 \mu \mathrm{g} / \mathrm{L}$ (micrograms per liter) in water, but some organochlorine pesticides were present in large concentrations in return flow and bottom sediment of wasteways (Bureau of Reclamation, 1982). The Washington State Department of Social and Health Services (WDSHS) $(1975,1976$, and 1977) detected $p, p$ DDE in water, and dieldrin in water and bottom sediment. Concentrations as much as $0.10 \mu \mathrm{g} / \mathrm{L}$ of $p, p$ DDE were found in water from Lower Crab Creek and Crab Creek Lateral; concentrations as much as $0.25 \mu \mathrm{g} / \mathrm{L}$ of dieldrin were found in water of Lind Coulee Wasteway. As part of their Pesticide Monitoring Program, the Washington State Department of Ecology (Ecology) sampled water from Crab Creek near Beverly in June 1992 (Davis, 1993). No organochlorine pesticides were detected, but the pesticides eptam, atrazine, simazine, dicamba, 2,4-D, dacthal, glyphosate, and disugran were detected.

Water quality in the Crab Creek and Palouse River drainages of the Central Columbia Plateau is currently (1994) being studied as part of the National Water Quality Assessment (NAWQA) program of the USGS. Preliminary sampling for trace elements and selected organic constituents in sediment and biota was done in 1992. Some of the sites sampled by NAWQA corresponded to sites chosen for this study and included Saddle Mountain Wasteway, Esquatzel Coulee Wasteway at Sagemoor Road, and Crab Creek near Beverly (J. C. Ebbert, U.S. Geological Survey, oral commun., 1993).

Metals and other trace elements in CBP terminus ponds were studied in 1986. Mercury concentrations were as much as $0.3 \mu \mathrm{g} / \mathrm{L}$; and boron concentrations ranged from 150 to $280 \mu \mathrm{g} / \mathrm{L}$ (J. W. Keys, Bureau of Reclamation, written commun., 1987). Boron concentrations appear to be increasing with time and could become a problem in the irrigation of boron-sensitive crops (E. L. Skinner and G.C. Bortleson, U.S. Geological Survey, written commun., September 1991).

Several studies have evaluated ground-water resources in the CBP and adjacent areas. Turney (1986), in an overview of ground-water quality, sampled water from 188 wells for $\mathrm{pH}$, specific conductance, dissolved solids, major ions, iron, manganese, nitrate-nitrogen, and fecal-coliform bacteria. Several stud es determined that ground water in parts of the CBP area contains large concentrations of sodium from natural sources (Turney, 1986; Bortleson and Cox, 1986; and Steinkampf, 1989).

Ground-water hydrology studies, which focused on the quantity and distribution of ground water and aquifers, include Walters and Grolier (1960) ard Tanaka and others (1974). A long-term study by the USFS Regional Aquifer Systems Analysis Group (RASA) described surficial geology (Drost and Whiteman, 1986), geologic framework (Drost and others, 1990), water levels (Bauer and others, 1985), and recharge (Bauer and Vaccaro, 1990) of the Columbia Basin.

The BR and USFWS monitored organochlorine and other pesticides in fish from the CBP for several years. The BR collected fish from 13 sites (6 of which were also sampled in this study) in 1975, 1977, 1978, and 1982 (Washington State Department of Social and Health Services, 1977, 1978, 1979). In addition, the USFWS collected and analyzed fish in 1982 and 1985 but did not publish the results. These agencies ccllected a total of 273 samples that included a variety of fisl species. Of the samples, 259 were analyzed as whole fish; the remaining were analyzed as fillets. DDT and its metabolites were detected in most fish from most of the sites, but in low concentrations. Only 6 percent of the concentrations in all fish samples exceeded National Acadomy of Sciences and National Academy of Engineering (NAS/NAE) (1973) criteria $(0.1 \mu \mathrm{g} / \mathrm{g}$ wet weight) for the protection of fish and fish-eating wildlife. Although dieldrin was detected in less than half of the fish samples, 34 fish samples had dieldrin concentrations exceeding prctection criteria $(0.1 \mu \mathrm{g} / \mathrm{g}$ wet weight). Other organochlorine compounds were detected infrequently and in corcentrations close to reporting limits.

Fish collected in 1985 by USFW'S were also analyzed for trace elements. For these analyses, a variety of species was collected and compositec into 24 whole-body samples. Three of the 24 samples had concentrations of arsenic, copper, and selenium that exceeded the 85th percentile levels determined from a nationwide monitoring program (Schmitt and Brumbaugh, 1990).

In 1989, samples of fish and bottom sediment from Moses Lake were analyzed for organnchlorine compounds and trace elements as part of Ecology's Lakes and Reservoir Water Quality Assessment Program (Johnson and Norton, 1990). Five black bullheads were analyzed as 
fillets without skin. Concentrations of detected contaminants were substantially less than the U.S. Food and Drug Administration (U.S. Food and Drug Administration, 1985) criteria for the protection of consumers. Total DDT concentrations of $0.04 \mu \mathrm{g} / \mathrm{g}$ in Moses Lake fish were the second largest of the fish samples collected from 10 lakes in the Ecology study. In bottom-sediment samples from the lakes, 4-methylphenol was the most frequently detected organic compound; the largest concentration $(1.6 \mu \mathrm{g} / \mathrm{g})$ was observed in one of the two Moses Lake samples. The herbicide tebuthiuron also was identified tentatively in one bottom-sediment sample. Concentrations of trace elements in the bottom sediment and in fish were not considered to be elevated.

Fish and bottom sediment samples were collected from Potholes Reservoir in 1992 as part of a contaminant screening survey by Ecology. Whole largescale suckers and composite samples of lake whitefish and largemouth bass fillets were analyzed for organochlorine pesticides, polychlorinated biphenyls (PCBs), and a few organophosphate pesticides. Fillet tissues also were analyzed for mercury and whole-body suckers were analyzed for all priority pollutant metals. Two bottom-sediment samples were analyzed for organochlorine pesticides, $\mathrm{PCBs}$, priority pollutant metals, semivolatile organics, organophosphate pesticides, and triazine herbicides. On the basis of dieldrin concentrations in fish muscle tissue, Ecology recommended Potholes Reservoir be considered for listing as water-quality limited under section 303(d) of the Clean Water Act.

Eggs of black-crowned night-herons were collected from the Potholes Reservoir nesting colony in 1979 (Henny and others, 1984) and analyzed for organochlorine insecticides. DDE concentrations in the eggs were the smallest concentrations in eggs from eight collection sites in Washington, Oregon, Idaho, and Nevada. Eggshells of birds from Potholes Reservoir were 4 percent thinner than those collected from across the Pacific Northwest prior to the beginning of DDT use in 1947. However, in eggs from the eight sites, Potholes Reservoir eggs exhibited the least thinning; the degree of thinning was considered to be biologically insignificant. Henny and others (1984) concluded that the herons were accumulating the bulk of DDT metabolites from wintering grounds in Latin America.

Acrolein (2-propenol) is an aquatic herbicide used by the irrigation districts within the CBP area to control aquatic plant growth in canals. Acrolein application has been implicated in several fish kills. In $\approx$ letter dated July 17, 1979, to Regional Fish Biologist Merrill Spence, WDW biologist Gene Tillett documented a fish kill following an acrolein application. Dead trout were found over a 4-mile reach downstream of the application point.

In Canada, the discharge of pulp-mil effluents introduced considerable amounts of dioxins into the Columbia River. Concentrations of dioxins, primarily 2,3,7,8-tetrachlorodibenzo-p-dioxin (TCDD) and 2,3 7,8-tetrachlorodibenzofuran (TCDF), have been detected in FDR Lake bottom sediment and fish (Johnson and cthers, 1991a, b).

Mining and metals processing in the Columbia River Basin in Canada upstream from the CBP greatly affect the water and bottom-sediment quality in the Columbia River and FDR Lake. These processing activit es discharge slag containing large quantities of copper, zinc, and arsenic into the Columbia River (S. E. Cox, U.S. Geological Survey, written commun., April 1993). The Spol'ane and Pend Orielle Rivers, tributaries to the Columbia River upstream from the CBP, also have been sources of zinc, lead, and cadmium to FDR Lake.

Bottom-sediment samples from the upper Columbia River were designated as "moderately polluted" to "severely polluted" with arsenic, cadmium, copper, iron, lead, mercury, manganese, and zinc when compared with EPA and Canadian bottom-sediment guidelines (Johnson and others, 1990; Arthur Johnson, Washington State Department of Ecology, written commur., 1991). Fish collected from the Grand Coulee Dam site as part of the USFWS National Contaminant Biomonitoring Program consistently contained elevated concentrations (exceeding the 85 th percentile concentration) of cad nium and lead, but elevated concentrations of arsenic and zinc were observed only once in the four sampling periods of this monitoring program (May and McKinnev: 1981; Lowe and others, 1985; Schmitt and Brumbaugh, 1990). Elevated lead concentrations were determined in bridgelip sucker fillets collected as part of Ecology's Basic Water Monitoring Program in 1984 (Hopkins and others, 1985). Elevated metals concentrations have alsc been determined by Canadian agencies in samples of fish, bottom sediment, algae, and invertebrates collected in the upstream reach of the international border (Smith, 1987). Because of the large metals and dioxin concentrations, a consumption advisory (British Columbia Ministry of Environment, 1990) was issued for walleye in this reach of the Columbia River. 


\section{SAMPLE COLLECTION AND ANALYSIS}

The study was designed to collect reconnaissancelevel data in the CBP before, during, and after the irrigation season. During the irrigation season (usually from March to October), the quantity and quality of water in streams, lakes, and wasteways are determined by imported Columbia River water and by return flow from irrigated cropland. During the non-irrigation season, ground water and subsurface return flow from cropland are the major components of the perennial streams and wasteways.

Twenty-one surface-water features (streams, wasteways, and lakes) were initially selected for sample collection to assess the quality of surface-water and irrigationreturn flows in and near the CBP fish and wildlife management areas. These water features included irrigation wasteway and return-flow drainages, natural streams, major storage reservoirs, and small lakes that collect wastewater or irrigation return-flow water. Because sampling logistics and requirements typically differ between the collection of water, bottom sediment, or biota samples, 24 sampling sites were selected to represent the 21 water features. Along with their corresponding map identifiers, the 24 sampling sites are shown in figure 9. Collecting the different types of biological samples, in addition to the water and bottom-sediment samples, resulted in a total of 70 sampling points (table 3 ).

From 15 primary water features, water samples were collected three times: in November 1991, after irrigation season; in March 1992, before irrigation season; and in July 1992, during irrigation season (table 4). At six secondary water features, water samples were collected only during the irrigation season. Bottom-sediment samples were collected from all 21 water features, but only during the irrigation season. Biological sample collection began in May 1992 and continued throughout the irrigation season; sampling sites and times of collection (table 5), and the type of data collected, depended on the organism of interest and its life stage.

The reference site for this study was Billy Clapp Lake (site BCL), which is located in the Stratford Unit of the North Columbia Basin Wildlife Area and is part of the Main Canal system to deliver irrigation water. Water quality at this site is assumed to be unaffected by irrigation practices and return-flow water. Rocky Ford Creek (site RFC), a well-known trout stream, carries surface, ground, and return-flow water into the Rocky Ford arm of Moses Lake (site MLR). Upper Crab Creek (site CCU) meanders through the Gloyd Seeps Unit of the North Columbia Basin Wildlife Area and empties into the Parker Horn arm of Moses Lake (site MLP). A third sampling site on Moses Lake at the lake's south end (sire MLS) is near the control dam linking Moses Lake to the east arm of Potholes Reservoir. Site PRW, located on the west arm of Potholes Reservoir and site PRE, located on the east arm of Potholes Reservoir, are both within the Potholes Unit of the South Columbia Basin Wildlife Area. Both Winchester Wasteway (site WW) and Frenchman Hills Wasteway (site FHW) flow through the Desert Unit of the South Columbia Basin Wildlife Area, and bo ${ }^{+h}$ discharge excess and return-flow water into Potholes Reservoir at the westcentral and southwestern shore, respectively. Lind Coulee Wasteway (site LCW) carries return flow into the southeastern end of Potholes Reservoir near O'Sullivan Dam. Soda Lake (site SL) is part of the Poth lles Canal system; Lower Goose Lake (site LGL) collects water from the terminus of West Canal and discharges into Lower Crab Creek (site CCM). Soda Lake and Lower Crab Creek are within the Columbia National Wildlife Refuge, and Lower Goose Lake is in the Seep Lakes State Wildlife Area. Sand Hollow Creek, on which two sampling sites (SHCa and $\mathrm{SHCb}$ ) were located, and Crab Creek near Beverly (site CCB) discharge wastewater into the Columbia River. Site CCB is within the Crab Creek Sta e Wildlife Area. Sampling sites on the major wasteway: in the southern part of the CBP that carry irrigation-re urn flows to the Columbia River include PE16.4 Waste'vay (site PEW) and Esquatzel Coulee Wasteway (site ECW').

Three water features in the southern part of the CBP--Saddle Mountain, Wahluke Brarch 10A, and EL68D Wasteways--each had sampling points located in a flowing section of the wasteway and downstream in the quiescent water of a lake that receives the wastewater. Water samples were collected in the flowing sections and bottom sediment and biota were collected in the lakes. Saddle Mountain Wasteway (site SMW') is located within the Saddle Mountain National Wildlife Refuge. A small lake in the Wahluke Wildlife Area was sampled for bottom sediment and biota, and referred to as Wahluke Branch Wasteway Lake (site WBWb) in this report. This lake receives wastewater and irrigation return flows from both Wahluke Branch 10A Wasteway, which was sampled for water at site WBWa, and Wahluke Branch 10 Wasteway. EL68D Wasteway (site ELW) was sampled for water and bottom sediment at its confluence with Potholes Canal, which discharges into Scooteney Reservoir; biota was collected from Scooteney Reservoir (site SR).

Water samples were analyzed for nutrients, major ions, trace elements, chlorophenoxy-acid herbicides, organophosphorus and organochlorine inse :ticides, PCBs, and 


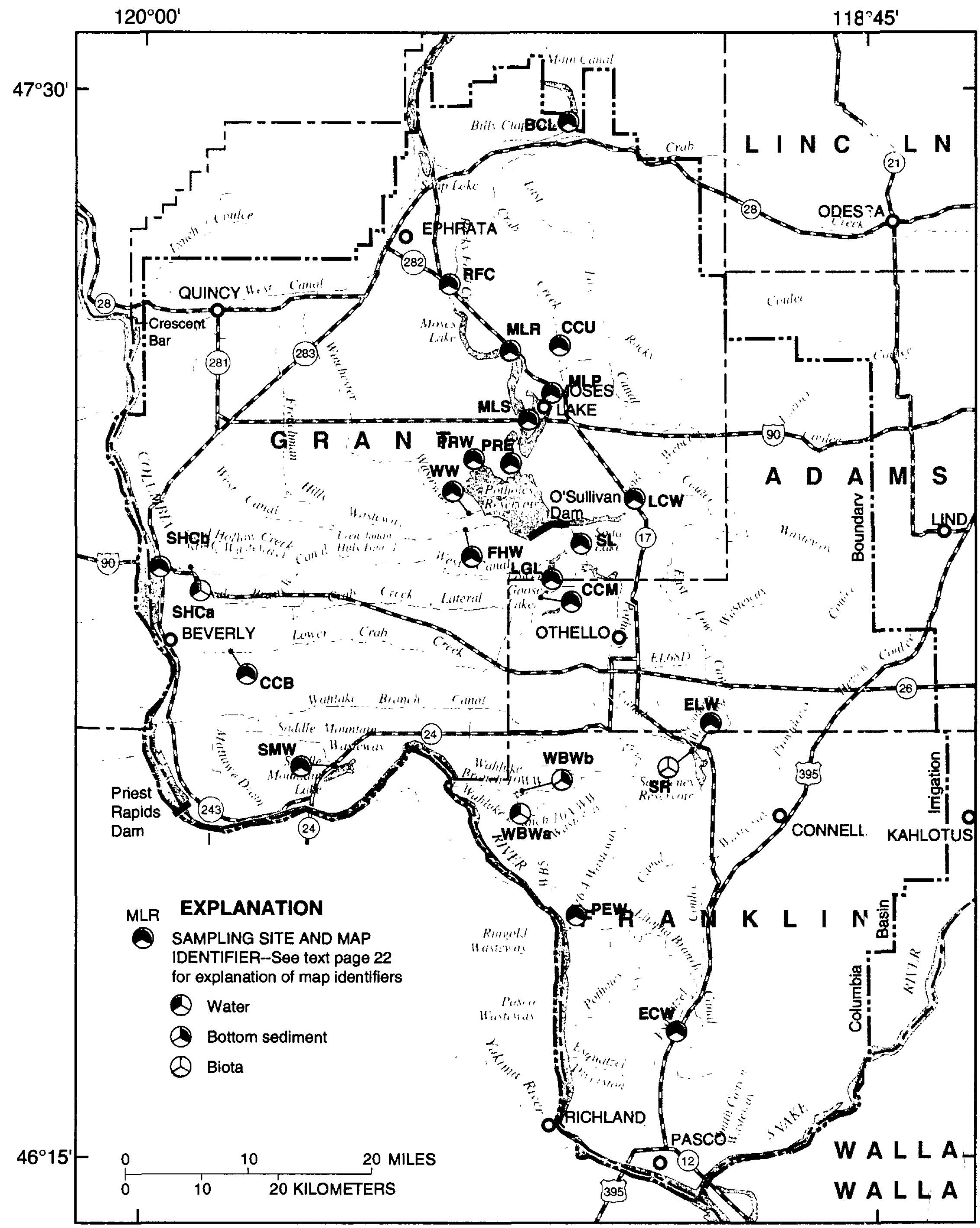

Figure 9.-Twenty-four sampling sites for water quality, bottom sediment, and biota in the Columbia Basin Project study area, 1991-92. 


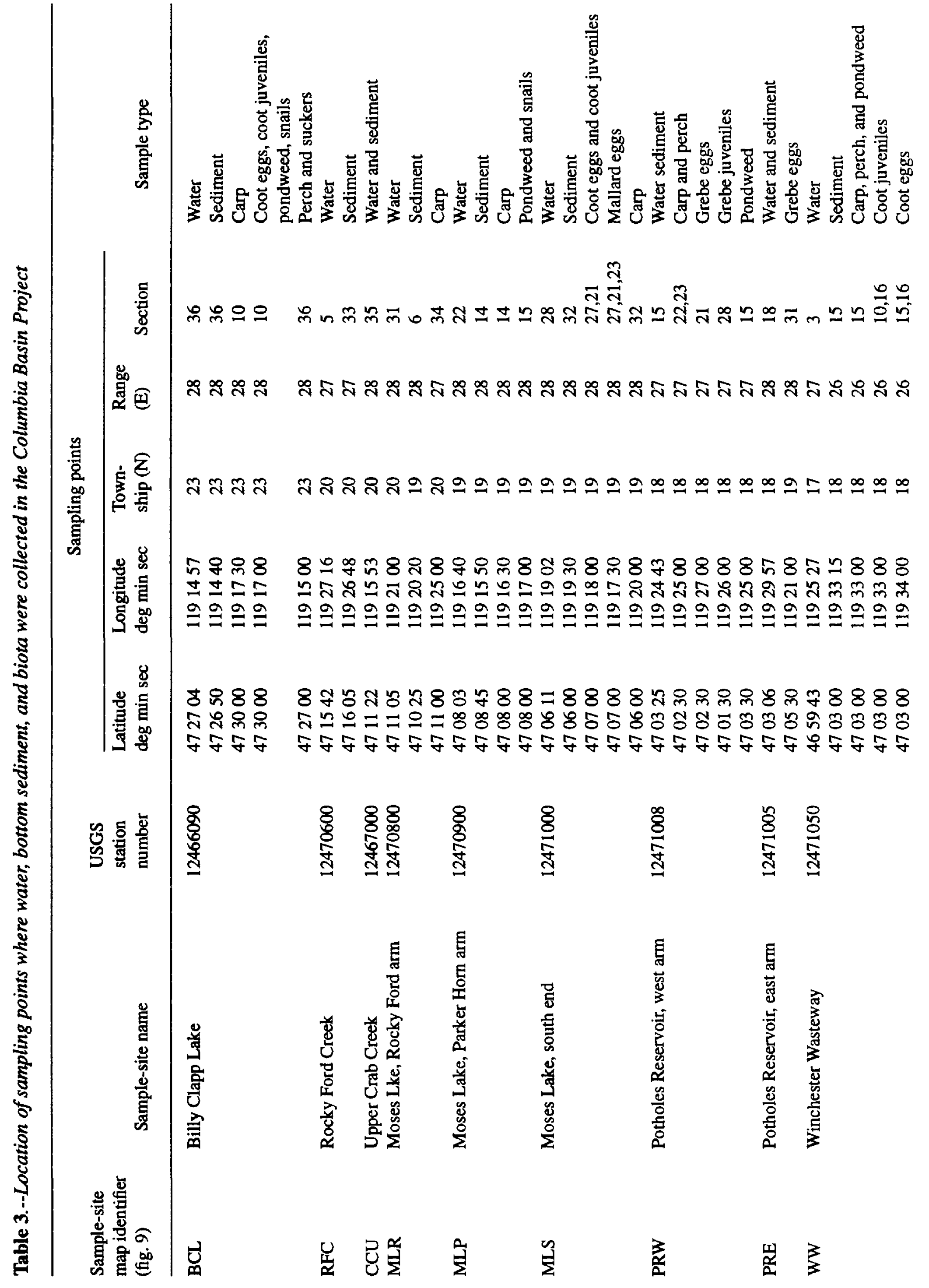




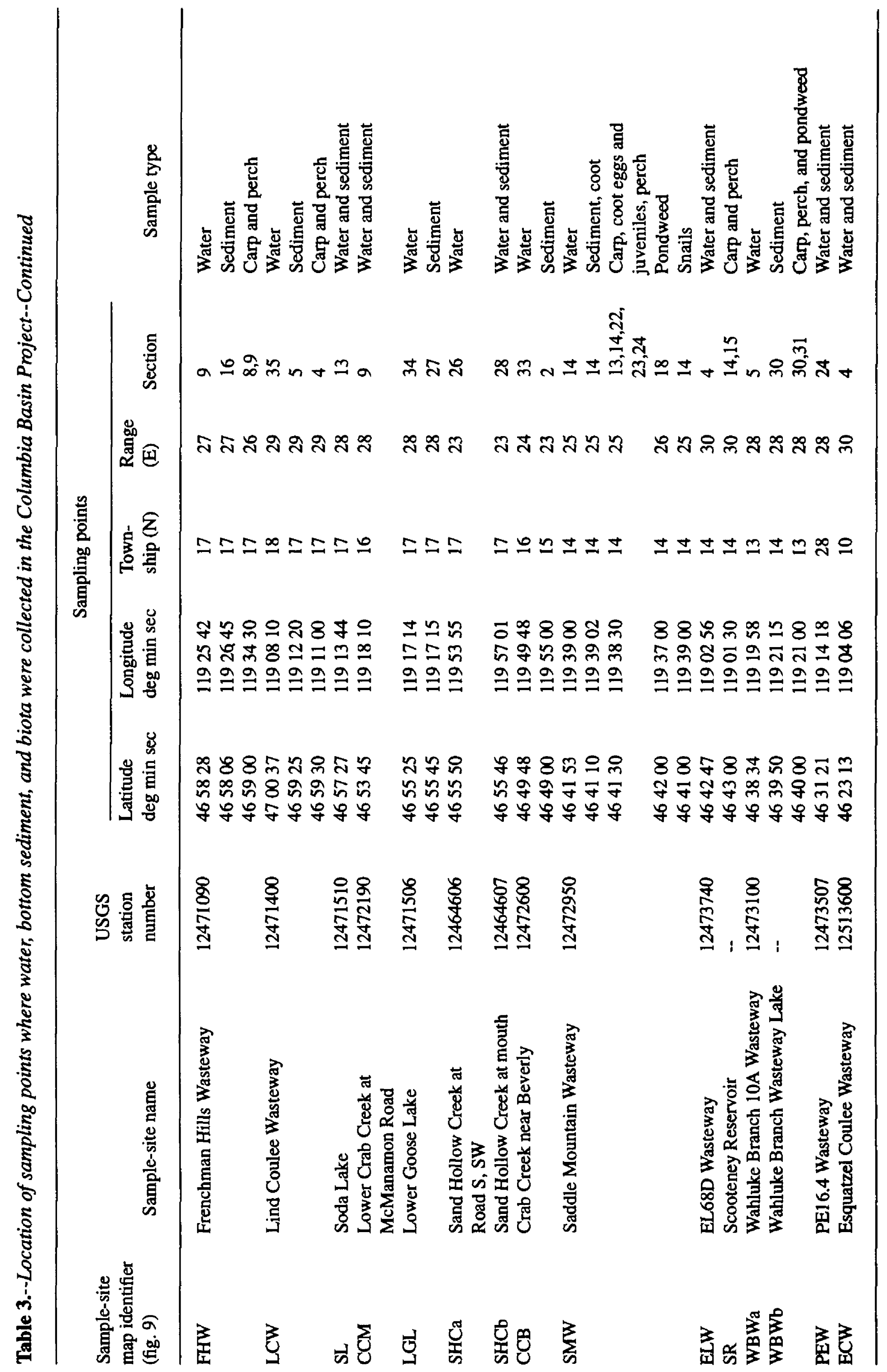


Table 4.--Sampling sites, types of constituents analyzed for, and schedule of sampling for water and bottom sediment in November 1991, March 1992, and July 1992 in the Columbia Basin Project

[X, sample was collected; --, no sample]

\begin{tabular}{|c|c|c|c|c|c|c|c|c|c|c|}
\hline \multirow{2}{*}{$\begin{array}{l}\text { Map } \\
\text { identi- } \\
\text { fier } \\
\text { (fig. 9) }\end{array}$} & \multirow[b]{2}{*}{ Site name } & \multirow[b]{2}{*}{$\begin{array}{l}\text { Sample } \\
\text { month }\end{array}$} & \multicolumn{5}{|c|}{ Water } & \multicolumn{3}{|c|}{ B Ittom sediment } \\
\hline & & & $\begin{array}{l}\text { Major } \\
\text { ions }\end{array}$ & $\begin{array}{l}\text { Nnt- } \\
\text { rients }\end{array}$ & $\begin{array}{l}\text { Trace } \\
\text { elements }\end{array}$ & $\begin{array}{l}\text { Pesti- } \\
\text { cides }\end{array}$ & $\begin{array}{l}\text { Bio- } \\
\text { assays }\end{array}$ & $\begin{array}{l}\text { Trace } \\
\text { element: }\end{array}$ & $\begin{array}{l}\text { Pesti- } \\
\text { cides }\end{array}$ & $\begin{array}{l}\text { Bio- } \\
\text { assays }\end{array}$ \\
\hline \multirow[t]{3}{*}{$\mathrm{BCL}$} & Billy Clapp Lake & November & $\mathbf{X}$ & $\mathbf{X}$ & $\mathbf{X}$ & $\mathbf{X}$ & $\mathbf{X}$ & -- & -- & $\ldots$ \\
\hline & & March & $\mathbf{X}$ & $\mathbf{X}$ & $\mathbf{x}$ & $\mathbf{X}$ & $\mathbf{X}$ & -- & - & - \\
\hline & & July & $\mathbf{X}$ & $\mathbf{X}$ & $\mathbf{X}$ & $\mathbf{X}$ & $\mathbf{X}$ & $\mathbf{X}$ & $\mathbf{X}$ & $\mathbf{X}$ \\
\hline \multirow[t]{3}{*}{ RFC } & Rocky Ford Creek & November & $\mathbf{X}$ & $\mathbf{x}$ & $\mathbf{X}$ & $\mathbf{x}$ & $\mathbf{x}$ & - & -- & - \\
\hline & & March & $\mathbf{x}$ & $\mathbf{X}$ & $\mathbf{x}$ & $\mathbf{X}$ & $\mathbf{X}$ & $\cdots$ & -- & -- \\
\hline & & July & $\mathbf{X}$ & $\mathbf{X}$ & $\mathbf{X}$ & $\mathbf{X}$ & $\mathbf{X}$ & $\mathbf{X}$ & $\mathbf{X}$ & $\mathbf{X}$ \\
\hline \multirow[t]{3}{*}{$\mathrm{CCU}$} & Upper Crab Creek & November & - & -- & -- & -- & -- & - & -- & -- \\
\hline & & March & - & - & -- & -- & -- & -- & -- & -- \\
\hline & & July & $\mathbf{X}$ & $\mathbf{X}$ & $\mathbf{X}$ & $\mathbf{X}$ & $\mathbf{X}$ & $\mathbf{X}$ & $\mathbf{X}$ & $\mathbf{X}$ \\
\hline \multirow[t]{3}{*}{ MLR } & Moses Lake, & November & $\mathbf{X}$ & $\mathbf{X}$ & $\mathbf{X}$ & $\mathbf{X}$ & $\mathbf{X}$ & -- & - & -- \\
\hline & Rocky Fond arm & March & $\mathbf{X}$ & $\mathbf{X}$ & $\mathbf{x}$ & $\mathbf{X}$ & $\mathbf{X}$ & - & - & - \\
\hline & & July & $\mathbf{x}$ & $\mathbf{x}$ & $\mathbf{X}$ & $\mathbf{x}$ & $\mathbf{x}$ & $\mathrm{X}$ & $\mathrm{X}$ & $\mathrm{X}$ \\
\hline \multirow[t]{3}{*}{ MLP } & Moses Lake, & November & $\ldots$ & -- & -- & - & -- & - & -- & - \\
\hline & Parker Hom arm & March & - & -- & -. & - & -- & -- & -- & - \\
\hline & & July & $\mathbf{x}$ & $\mathbf{x}$ & $\mathbf{X}$ & $\mathbf{x}$ & $\mathbf{x}$ & $\mathrm{x}$ & $\mathbf{x}$ & $\mathbf{x}$ \\
\hline \multirow[t]{3}{*}{ MLS } & Moses Lake, & November & $\mathbf{X}$ & $\mathbf{X}$ & $\mathbf{x}$ & $\mathbf{x}$ & $\mathbf{x}$ & - & -- & -- \\
\hline & south end & March & $\mathbf{X}$ & $\mathbf{x}$ & $\mathbf{X}$ & $\mathbf{x}$ & $\mathbf{X}$ & -- & -- & - \\
\hline & & July & $\mathbf{X}$ & $\mathbf{X}$ & $\mathbf{X}$ & $\mathbf{X}$ & $\mathbf{X}$ & $\mathbf{X}$ & $X$ & $\mathrm{X}$ \\
\hline \multirow[t]{3}{*}{ PRW } & Potholes Reservoir, & November & $\mathbf{x}$ & $\mathbf{x}$ & $\mathbf{X}$ & $\mathbf{X}$ & $\mathbf{X}$ & -- & -- & - \\
\hline & west arm & March & $\mathbf{x}$ & $\mathbf{X}$ & $\mathbf{X}$ & $\mathbf{X}$ & $\mathbf{X}$ & -- & - & - \\
\hline & & July & $\mathbf{x}$ & $\mathbf{x}$ & $\mathbf{X}$ & $\mathbf{X}$ & $\mathbf{X}$ & $\mathbf{x}$ & $\mathbf{X}$ & $\mathrm{X}$ \\
\hline \multirow[t]{3}{*}{ PRE } & Potholes Reservoir, & November & - & -- & -- & - & -- & - & -- & -- \\
\hline & east arm & March & - & -. & - & - & -- & - & -- & -. \\
\hline & & July & $\mathbf{x}$ & $\mathbf{x}$ & $\mathbf{X}$ & $\mathbf{X}$ & $\mathbf{x}$ & $\mathbf{x}$ & $\mathbf{x}$ & $\mathrm{x}$ \\
\hline \multirow[t]{3}{*}{ WW } & Winchester & November & $\mathbf{x}$ & $\mathbf{X}$ & $\mathbf{X}$ & $\mathbf{X}$ & $\mathbf{X}$ & - & -- & - \\
\hline & Wasteway & March & $\mathbf{x}$ & $\mathbf{x}$ & $\mathbf{X}$ & $\mathbf{X}$ & $\mathbf{X}$ & - & -- & - \\
\hline & & July & $\mathbf{x}$ & $\mathbf{x}$ & $\mathbf{x}$ & $\mathbf{X}$ & $\mathbf{X}$ & $\mathbf{X}$ & $\mathbf{X}$ & $\mathrm{X}$ \\
\hline \multirow[t]{3}{*}{ FHW } & Frenchman Hills & November & $\mathbf{X}$ & $\mathbf{X}$ & $\mathbf{X}$ & $\mathbf{X}$ & $\mathbf{X}$ & -- & -- & -- \\
\hline & Wasteway & March & $\mathbf{X}$ & $\mathbf{x}$ & $\mathbf{X}$ & $\mathbf{x}$ & $\mathrm{X}$ & - & -- & - \\
\hline & & July & $\mathbf{x}$ & $\mathbf{x}$ & $\mathbf{x}$ & $\mathbf{x}$ & $\mathrm{X}$ & $\mathrm{X}$ & $\mathbf{X}$ & $\mathbf{X}$ \\
\hline \multirow[t]{3}{*}{ LCW } & Lind Coulee & November & $\mathbf{X}$ & $\mathbf{x}$ & $\mathbf{x}$ & $\mathbf{X}$ & $\mathrm{x}$ & -- & -- & -- \\
\hline & Wasteway & March & $\mathbf{X}$ & $\mathbf{x}$ & $\mathbf{x}$ & $\mathbf{x}$ & $\mathrm{X}$ & -- & -- & -- \\
\hline & & July & $\mathbf{x}$ & $\mathbf{X}$ & $\mathbf{x}$ & $\mathbf{X}$ & $\mathbf{X}$ & $\mathbf{x}$ & $\mathbf{X}$ & $\mathrm{x}$ \\
\hline
\end{tabular}


Table 4.--Sampling sites, types of constituents analyzed for, and schedule of sampling for water and tonttom sediment in November 1991, March 1992, and July 1992 in the Columbia Basin Project--Continued

\begin{tabular}{|c|c|c|c|c|c|c|c|c|c|c|}
\hline \multirow{2}{*}{$\begin{array}{l}\text { Map } \\
\text { identi- } \\
\text { fier } \\
\text { (fig. 9) }\end{array}$} & \multirow[b]{2}{*}{ Site name } & \multirow[b]{2}{*}{$\begin{array}{l}\text { Sample } \\
\text { month }\end{array}$} & \multicolumn{5}{|c|}{ Worter } & \multicolumn{3}{|c|}{ Bostom sertiment } \\
\hline & & & $\begin{array}{l}\text { Major } \\
\text { ions }\end{array}$ & $\begin{array}{l}\text { Nut- } \\
\text { rients }\end{array}$ & $\begin{array}{l}\text { Trace } \\
\text { elements }\end{array}$ & $\begin{array}{l}\text { Pesti- } \\
\text { cides }\end{array}$ & $\begin{array}{l}\text { Bio- } \\
\text { assays }\end{array}$ & $\begin{array}{l}\text { Trace } \\
\text { elements }\end{array}$ & $\begin{array}{l}\text { Pesti- } \\
\text { cides }\end{array}$ & $\begin{array}{l}\text { Bio- } \\
\text { assays }\end{array}$ \\
\hline \multirow[t]{3}{*}{ SL } & Soda Lake & November & $\mathbf{x}$ & $\mathbf{x}$ & $\mathbf{x}$ & $\mathbf{x}$ & $\mathbf{x}$ & -- & -- & -- \\
\hline & & March & $\mathbf{x}$ & $\mathrm{x}$ & $\mathbf{x}$ & $\mathbf{x}$ & $\mathbf{x}$ & - & - & - \\
\hline & & July & $\mathbf{x}$ & $\mathbf{x}$ & $\mathbf{x}$ & $\mathbf{x}$ & $\mathbf{x}$ & $\mathrm{x}$ & $\mathbf{x}$ & $\mathbf{x}$ \\
\hline \multirow[t]{3}{*}{$\mathrm{CCM}$} & Lower Crab Creek & November & -- & - & - & - & - & - & - & - \\
\hline & at McManamon & March & - & - & - & -- & -. & -- & - & - \\
\hline & Road & July & $\mathbf{x}$ & $\mathbf{x}$ & $\mathbf{x}$ & $\mathbf{x}$ & $\mathbf{x}$ & $\mathbf{x}$ & $\mathbf{x}$ & $\mathbf{x}$ \\
\hline \multirow[t]{3}{*}{ LGL } & Lower Goose Lake & November & - & - & - & - & - & - & - & -- \\
\hline & & March & -- & -- & - & - & - & - & - & - \\
\hline & & July & $\mathbf{x}$ & $\mathbf{x}$ & $\mathbf{x}$ & $\mathbf{x}$ & $\mathbf{x}$ & $\mathbf{x}$ & $\mathbf{x}$ & $\mathbf{x}$ \\
\hline \multirow[t]{3}{*}{ SHCa } & Sand Hollow Creek & November & - & -- & - & - & - & - & - & - \\
\hline & at Road S, SW & March & $\mathbf{x}$ & $\mathbf{x}$ & $\mathbf{x}$ & $\mathbf{x}$ & $\mathrm{x}$ & - & - & - \\
\hline & (RB4C Wasteway) & July & $\mathbf{x}$ & $\mathbf{x}$ & $\mathbf{x}$ & $x$ & $\mathbf{x}$ & - & - & - \\
\hline \multirow[t]{3}{*}{$\mathrm{SHCb}$} & Sand Hollow Creek & November & $\mathbf{x}$ & $\mathbf{x}$ & $\mathbf{x}$ & $\mathbf{x}$ & $\mathbf{x}$ & - & - & -- \\
\hline & at mouth (RB4C & March & -. & - & -- & - & - & - & -- & - \\
\hline & Wasteway) & July & -- & - & -- & - & - & $\mathbf{x}$ & $\mathbf{x}$ & $\mathbf{x}$ \\
\hline \multirow[t]{3}{*}{$\mathrm{CCB}$} & Crab Creek near & November & $\mathbf{x}$ & $\mathbf{x}$ & $\mathrm{x}$ & $\mathbf{x}$ & $\mathbf{x}$ & - & .- & - \\
\hline & Beverly & March & $\mathbf{x}$ & $\mathbf{x}$ & $\mathbf{x}$ & $\mathbf{x}$ & $\mathbf{x}$ & - & - & - \\
\hline & & July & $\mathbf{x}$ & $\mathbf{x}$ & $\mathbf{x}$ & $\mathbf{x}$ & $\mathbf{x}$ & $\mathbf{x}$ & $\mathrm{x}$ & $\mathbf{x}$ \\
\hline \multirow[t]{3}{*}{ SMW } & Saddle Mountain & November & - & - & - & - & - & - & - & - \\
\hline & Wasteway & March & - & - & - & - & - & - & - & - \\
\hline & & July & $\mathbf{x}$ & $\mathbf{x}$ & $\mathbf{x}$ & $\mathbf{x}$ & $\mathbf{x}$ & $\mathbf{x}$ & $\mathbf{x}$ & $x$ \\
\hline \multirow[t]{3}{*}{ ELW } & EL68D Wasteway & November & $\mathbf{x}$ & $\mathbf{x}$ & $\mathbf{x}$ & $\mathbf{x}$ & $\mathbf{x}$ & - & - & - \\
\hline & & March & $\mathbf{x}$ & $\mathbf{x}$ & $\mathbf{x}$ & $\mathbf{x}$ & $\mathbf{x}$ & - & - & - \\
\hline & & July & $\mathbf{x}$ & $\mathbf{x}$ & $\mathbf{x}$ & $\mathbf{x}$ & $\mathbf{x}$ & $\mathbf{x}$ & $\mathbf{x}$ & $\mathbf{x}$ \\
\hline \multirow{3}{*}{ WBWa } & Wahluke Branch & November & $\mathbf{x}$ & $\mathbf{x}$ & $\mathbf{x}$ & $\mathbf{x}$ & $\mathbf{x}$ & - & - & - \\
\hline & 10A Wasteway & March & $\mathbf{x}$ & $\mathbf{x}$ & $\mathbf{x}$ & $\mathrm{x}$ & $\mathbf{x}$ & - & - & - \\
\hline & & July & $\mathbf{x}$ & $\mathbf{x}$ & $\mathbf{x}$ & $\mathbf{x}$ & $\mathbf{x}$ & - & - & - \\
\hline WBWb & $\begin{array}{l}\text { Wahluke Branch } \\
\text { Wasteway Lake }\end{array}$ & July & - & -- & - & -- & - & $\mathrm{x}$ & $\mathbf{x}$ & $\mathbf{x}$ \\
\hline \multirow[t]{3}{*}{ PEW } & PE16.4 Wasteway & November & $\mathbf{x}$ & $\mathbf{x}$ & $\mathbf{x}$ & $\mathbf{x}$ & $\mathbf{x}$ & -- & - & - \\
\hline & & March & $\mathbf{x}$ & $\mathbf{x}$ & $x$ & $\mathbf{x}$ & $\mathbf{x}$ & - & - & - \\
\hline & & July & $x$ & $\mathbf{x}$ & $x$ & $\mathrm{x}$ & $x$ & $\mathbf{x}$ & $\mathbf{x}$ & $\mathbf{x}$ \\
\hline \multirow[t]{3}{*}{ ECW } & Esquatzel Coulee & November & $\mathbf{x}$ & $\mathbf{x}$ & $\mathrm{x}$ & $\mathbf{x}$ & $\mathrm{x}$ & .- & - & - \\
\hline & Wasteway & March & $\mathbf{x}$ & $\mathbf{x}$ & $\mathbf{x}$ & $\mathbf{x}$ & $\mathrm{x}$ & .. & - & - \\
\hline & & July & $\mathbf{x}$ & $\mathbf{x}$ & $\mathbf{x}$ & $\mathbf{x}$ & $\mathbf{x}$ & $\mathbf{x}$ & $\mathbf{x}$ & $\mathbf{x}$ \\
\hline
\end{tabular}




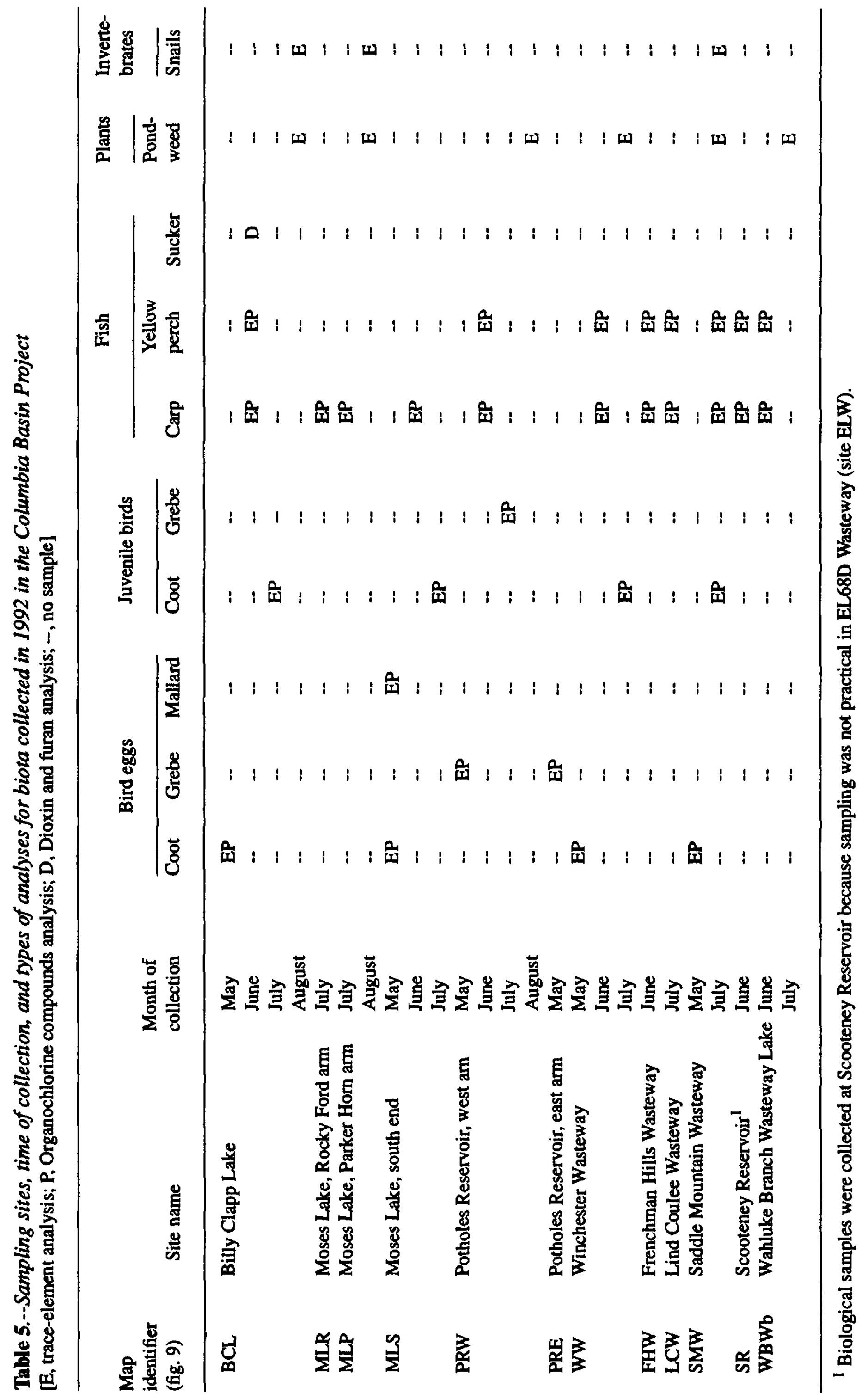


polychlorinated naphthalenes (PCNs). Bottom-sediment sample analytes included selected trace elements, total organic carbon, organochlorine insecticides, PCBs, and PCNs. The potential toxicity of water and bottom sediment to aquatic organisms was also evaluated. Daphnia magna and the Microtox bioassay bacteria (Microbics Corporation, 1992) were the test organisms exposed to surface water and Chironomus tentans was exposed to bottom sediment. Analyses of the biota focused on concentrations of selected trace elements and pesticides in bird eggs and animal and plant tissues. Tissue samples of the biota were analyzed for selecter trace elements, organochlorine pesticides, PCBs, d oxins, and furans. Table 6 lists analytical reporting linits for selected trace elements, and table 7 lists analytical reporting limits for selected organic compounds.

Table 6.--Analytical reporting limits for selected trace elements in water, bottom sediment, and biotc: $[\mu \mathrm{g} / \mathrm{L}$, micrograms per liter; $\mu \mathrm{g} / \mathrm{g}$, micrograms per gram; --, no analysis]

\begin{tabular}{|c|c|c|c|c|c|c|}
\hline \multirow{4}{*}{$\frac{\text { Constituent }}{\text { Aluminum }}$} & \multirow{4}{*}{$\begin{array}{c}\text { Water } \\
(\mu g / L)\end{array}$} & \multicolumn{5}{|c|}{ Analytical Reporting Limit } \\
\hline & & \multirow[b]{2}{*}{$\begin{array}{l}\text { Bottom sediment } \\
(\mu \mathrm{g} / \mathrm{g}, \text { dry } \\
\text { weight })\end{array}$} & \multicolumn{4}{|c|}{ Biota } \\
\hline & & & \multicolumn{2}{|c|}{$\begin{array}{l}\text { Animal tissue }{ }^{1} \\
(\mu \mathrm{g} / \mathrm{g}, \text { wet } \\
\text { weight })\end{array}$} & \multicolumn{2}{|c|}{$\begin{array}{l}\text { Plant tissue } \\
\text { ( } \mu \mathrm{g} / \text { ?. wet } \\
\text { weight) }\end{array}$} \\
\hline & & 5 & 1.4 & $(1.0-3.7)$ & 1.4 & $(1.1-2.0)$ \\
\hline Arsenic & 1 & 0.1 & 0.13 & $(0.06-0.38)$ & 0.14 & $(. .11-0.19)$ \\
\hline Barium & 100 & 1 & 0.13 & $(0.10-0.37)$ & 0.14 & $(0.11-0.20)$ \\
\hline Beryllium & -- & 1 & 0.03 & $(0.019-0.073)$ & 0.029 & $(7.022-0.039)$ \\
\hline Boron & 10 & 0.2 & 0.13 & $(0.10-0.37)$ & 0.14 & $(. .11-0.20)$ \\
\hline Cadmium & 1 & 2 & 0.03 & $(0.019-0.073)$ & 0.029 & $(. .022-0.039)$ \\
\hline Chromium & 1 & 1 & 0.13 & $(0.10-0.37)$ & 0.14 & $(0.11-0.20)$ \\
\hline Copper & 1 & 1 & 0.13 & $(0.10-0.37)$ & 0.14 & $(0.11-0.20)$ \\
\hline Iron & 10 & 5 & 3.0 & $(1.9-7.3)$ & 2.9 & $(2.2-3.9)$ \\
\hline Lead & 5 & 4 & 0.13 & $(0.10-0.37)$ & 0.14 & $(0.11-0.20)$ \\
\hline Mercury & 0.1 & 0.02 & 0.03 & $(0.019-0.073)$ & 0.0281 & $(0.0218-0.0381)$ \\
\hline Magnesium & 100 & 5 & 3.0 & $(1.9-7.3)$ & 2.9 & $(2.2-3.9)$ \\
\hline Manganese & 10 & 20 & 0.11 & $(0.077-0.294)$ & 0.116 & $(0.086-0.157)$ \\
\hline Molybdenum & 1 & 2 & 0.13 & $(0.10-0.37)$ & 0.14 & $(0.11-0.20)$ \\
\hline Nickel & - & 2 & 0.13 & $(0.10-0.37)$ & 0.14 & $(0.11-0.20)$ \\
\hline Selenium & 1 & 0.1 & 0.13 & $(0.06-0.38)$ & 0.14 & $(0.11-0.19)$ \\
\hline Silver & -- & 2 & - & -- & -- & -- \\
\hline Strontium & 10 & 2 & 0.05 & $(0.039-0.146)$ & 0.06 & $(0.04-0.08)$ \\
\hline Tin & -- & 5 & -- & -- & -- & -. n n \\
\hline Uranium & 0.4 & 0.2 & -- & -- = - & -- & -- \\
\hline Vanadium & 1 & 2 & 0.13 & $(0.10-0.37)$ & 0.14 & $(0.11-0.20)$ \\
\hline Zinc & 3 & 4 & 0.30 & $(0.19-0.73)$ & 0.29 & $(0.22-0.39)$ \\
\hline
\end{tabular}

${ }^{1}$ Animal tissue, estimated median value (range).

${ }^{2}$ Plant tissue, calculated median value (range). 
Table 7.--Compounds and analytical reporting limits for selected organic compounds in water, bottom sediment, and biota

[ $\mu \mathrm{g} / \mathrm{L}$, micrograms per liter; $\mu \mathrm{g} / \mathrm{kg}$, micrograms per kilogram; $\mu \mathrm{g} / \mathrm{g}$, micrograms per gram; --, no analysis]

\begin{tabular}{|c|c|c|}
\hline \multirow[b]{2}{*}{ Compound (trade name) } & \multicolumn{2}{|c|}{ Analytical Reporting Limit } \\
\hline & $\begin{array}{l}\text { Whole water } \\
(\mu g / L)\end{array}$ & $\begin{array}{l}\text { Bottom sediment, } \\
\text { dry weight } \\
(\mu \mathrm{g} / \mathrm{kg})\end{array}$ \\
\hline Aldrin & 0.001 & 0.1 \\
\hline Chlordane & 0.1 & 1 \\
\hline Chlorpyrifos (Lorsban) & 0.01 & - \\
\hline DDD & 0.001 & 0.1 \\
\hline DDE & 0.001 & 0.1 \\
\hline DDT & 0.001 & 0.1 \\
\hline Diazinon & 0.01 & -- \\
\hline Dieldrin & 0.001 & 0.1 \\
\hline Disulfoton (Disyston) & 0.01 & -- \\
\hline Endosulfan (Thiodan) & 0.001 & 0.1 \\
\hline Endrin & 0.001 & 0.1 \\
\hline Ethion & 0.01 & -- \\
\hline Ethylan (Perthane) & 0.1 & 1 \\
\hline Fonofos (Dyfonate) & 0.01 & -- \\
\hline Heptachlor & 0.001 & 0.1 \\
\hline Heptachlor epoxide & 0.001 & 0.1 \\
\hline Lindane & 0.001 & 0.1 \\
\hline Malathion & 0.01 & -- \\
\hline Methoxychlor & 0.01 & 0.1 \\
\hline Methyl parathion & 0.01 & -- \\
\hline Mirex & 0.01 & 0.1 \\
\hline Parathion & 0.01 & -- \\
\hline Phorate (Thimet, Rampart) & 0.01 & -- \\
\hline Toxaphene & 1 & 10 \\
\hline Trithion & 0.01 & - \\
\hline 2,4-D & 0.01 & -- \\
\hline $2,4,5-T$ & 0.01 &.- \\
\hline 2,4-DP & 0.01 & -- \\
\hline Dicamba (Banvel) & 0.01 & -- \\
\hline Picloram (Tordon) & 0.01 & - \\
\hline $\begin{array}{l}\text { S,S,S-Tributylphosphoro- } \\
\text { trithioate (DEF) }\end{array}$ & 0.01 & - \\
\hline 2,3,4-TP (Silvex) & 0.01 & -- \\
\hline Total Polychlorinated Biphenyls (PCBs) & 0.1 & 1 \\
\hline Polychlorinated naphthalenes (PCNs) & 0.1 & 1 \\
\hline
\end{tabular}


Table 7.--Compounds and analytical reporting limits for selected organic compounds in water, bottom sediment, and biota--Continued

\begin{tabular}{|c|c|}
\hline \multirow[b]{2}{*}{ Compound } & \multirow{2}{*}{ 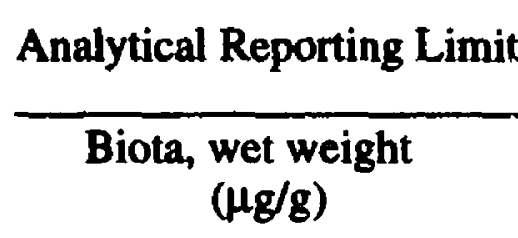 } \\
\hline & \\
\hline Hexachlorobenzene (HCB) & 0.01 \\
\hline$\alpha$-Benzene Hexachloride (BHC) & 0.01 \\
\hline$\Gamma-\mathrm{BHC}$ & 0.01 \\
\hline B-BHC & 0.01 \\
\hline$\delta-\mathrm{BHC}$ & 0.01 \\
\hline Toxaphene & 0.05 \\
\hline Total PCBs & 0.05 \\
\hline Dieldrin & 0.01 \\
\hline Endrin & 0.01 \\
\hline Mirex & 0.01 \\
\hline Methoxychlor & 0.01 \\
\hline Oxychlordane & 0.01 \\
\hline Heptachlor Epoxide & 0.01 \\
\hline Trans-Chlordane & 0.01 \\
\hline Trans-Nonachlor & 0.01 \\
\hline Cis-Chlordane & 0.01 \\
\hline Cis-Nonachlor & 0.01 \\
\hline$o, p \mathrm{DDE}$ & 0.01 \\
\hline$p, p \mathrm{DDE}$ & 0.01 \\
\hline$o, p$ DDD & 0.01 \\
\hline$o, p$ DDT & 0.01 \\
\hline$p, p$ DDD & 0.01 \\
\hline$p, p \mathrm{DDT}$ & 0.01 \\
\hline
\end{tabular}


Field measurements included specific conductance, $\mathrm{pH}$, and concentrations of dissolved oxygen and alkalinity. At lake and reservoir sites, a Secchi-disk measurement of water clarity and depth profiles of specific conductance, water temperature, and dissolved oxygen were made. The depth profiles were used to determine the extent of thermal or salinity stratification of water in the lakes.

\section{Water}

Water samples were collected from streams and wasteways with the width- and depth-integrating techniques described by Edwards and Glysson (1988) and Ward and Harr (1990). The samples were collected at several verticals in the cross section with either a D-77-TM depth-integrating sampler (suitable for trace-metal collection and equipped with teflon nozzle and gasket) or DH-81 depth-integrating sampler (equipped with teflon bottle, cap, and nozzle assembly suitable for trace-element and organic-compound collection) and composited either in two separate churn splitters (one plastic churn splitter and one teflon-lined churn splitter) or split with a teflon cone splitter into appropriate bottles. The teflon-lined churn splitter contained the composited water for pesticide and organic compounds analyses. The plastic churn splitter contained the composited water for the nutrient, majorions, and trace-element analyses. Water temperature and dissolved oxygen were measured in the center flow of the stream. Specific conductance, alkalinity, and $\mathrm{pH}$ were measured on subsamples of composited water from the plastic churn splitter according to standard USGS procedures (M. A. Sylvester, U.S. Geological Survey, written commun., September 1990).

During pre- and post-irrigation season when the lakes were not stratified with respect to temperature, dissolved oxygen, or specific conductance, water samples from the lakes and reservoirs were collected with a DH-76-TM depth-integrating sampler (equipped with teflon nozzle and gasket), and a solvent-cleansed glass bottle. The sampler was lowered and raised through the upper 15 to 20 feet of the water column while slowly moving the boat forward. Samples were composited in churn splitters (one plastic and one teflon-lined). During mid-irrigation season, when the lakes were thermally stratified into epilimnion, metalimnion, and hypolimnion, point samples were collected from the three layers with a teflon Kemmerer-type sampler and composited in the churn splitters. Specific conductance, alkalinity, and $\mathrm{pH}$ of subsamples of the composited water were recorded.
Water for major-ion, nutrient, and trace-element analyses was filtered through a $\mathbf{0 . 4 5}$ micrometer membrane filter; water for pesticide and organic compounds analyses was not filtered. In this report, filterable-constituent concentrations are referred to as "dissolved" and whole-water constituent concentratic ns are referred to as either "total" or "total-recoverable." The samples were preserved, placed on ice as appropria'e, and shipped to the USGS National Water Quality Laboratory (NWQL) in Arvada, Colo., and analyzed according to procedures described in Fishman and Friedman (1989), Wershaw and others (1987), and Pritt and Jones (1989).

Water samples for the Microtox and Daphnia magna bioassays usually were collected on the same days as the water chemistry samples. Of 51 samples collected for testing water toxicity, 75 percent wer collected on the same day, 21 percent were collected within 1 day, and 4 percent were collected within 2 days. For the Microtox bioassay, water was collected in clean, (quality assured by the supplier) 125-mL (milliliters) glass jars; for the daphnid bioassay, water was collected in 1-liter plastic jars. To fill the jars, the collector waded into water that was from 2 to 4 feet deep, allowed disturbed material to settle, rinsed the jars with native water, and then s'owly immersed the jars to maximize the amount of surfase microlayer (where contaminants concentrate) in the sample. The jars were filled without air entrapment, then placed on ice. Samples were tested at the USFWS office at Mtoses Lake with the Microtox procedures on the same dav as sample collection. The samples for the daphnid bioassays were shipped by overnight carrier to the testing laboratory in Watsonville, Calif., on the day of col'ection.

For the Microtox bioassay, biol uminescent bacteria were exposed to a dilution series of 9), 45, 22.5, and 11.25 percent sample water, and to one control without sample water. Bacterial light production war measured at 5 and 15 minutes after exposure, and an EC.50 was calculated. The EC50 is the calculated concentration of sample water at which the presence of toxic compornds or water-quality conditions reduces bacterial light production by 50 percent. The EC50 values of samples can be used to make comparisons among study sites.

The daphnid bioassay conformed to the procedures described by the USEPA (1985). In this test, five Daphnia magna individuals less than 24 hours old were added to each of four, 20 -mL beakers containing aerated sample water. The survival of the daphnids was determined 24 and 48 hours after test initiation, according to methods described by Toxscan, Inc. (1991, 1992a, b). 


\section{Bottom Sediment}

Bottom-sediment samples from streams and wasteways were collected with acid-rinsed, solvent-cleansed glass beakers in various depositional environments along a cross section of the stream. Bottom-sediment samples from lakes and reservoirs were collected with a brass Ekman dredge from five or more depositional environments near shorelines. Core samples were collected from the center of the dredge where the bottom sediment was not in contact with the metal of the dredge. The samples were composited in a 6-liter acid-rinsed, solvent-cleansed glass bowl and split into subsamples for bioassays and chemical analyses. The subsamples for trace-element analyses were placed in pint-sized plastic containers and sent to the USGS Geologic Division Analytical Laboratory in Denver, Colo. At the laboratory, the samples were air dried and sieved through screens with 2-mm (millimeter) openings. Total major and minor elements and organic-carbon content were determined on the fraction of material passing through the 2-mm screen, according to methods described by Severson and others (1987). Subsamples of bottom sediment for pesticide and organic compounds analyses were sieved in the field through a stainless steel sieve. The fraction passing through the 2-mm openings of the sieve was placed into $500-\mathrm{mL}$ glass jars, and shipped on ice to the USGS Water Resources Division NWQL in Arvada, Colo. Pesticides and organic compounds in bottom sediment were analyzed according to the methods described by Wershaw and others (1987).

Subsamples of bottom sediment for bioassays were placed into plastic jars, held on ice in the field, and shipped by overnight carrier to the laboratory at the University of Minnesota Cooperative Fish and Wildlife Research Unit. Most samples were shipped on the day of collection, but some were refrigerated overnight and shipped the following day. At the laboratory, Chironomus tentans bioassays were run on the samples. Of the 21 samples collected from Lower Goose Lake, Potholes Reservoir (east arm), Soda Lake, Saddle Mountain Wasteway, and Wahluke Branch Wasteway Lake, 5 were tested within 24 hours of receipt; 16 samples were stored at $4^{\circ} \mathrm{C}$ (degrees Celsius) for 27 days before testing.

For the chironomid bioassay, 15 test tubes were used for each site. Each of the test tubes was filled with 7.5 grams of bottom sediment from a site, mixed with $40 \mathrm{~mL}$ of deionized water, inverted 5 times, and allowed to settle for 24 hours (Henry and Jaschke, n.d.). For each of 2 control samples, 15 tubes received clean reference material. All the tubes were then aerated for 24 hours, after which a single cultured second-instar chironomid larva was placed into each tube containing either sample or reference sediment. At the end of a 10-day exposure period with continuous aeration, food supply, and volume of $50 \mathrm{~mL}$, the contents of each tube was emptied onto a benthos sorting screen and searched for the larvae. Larvae received one of the following designations: dead, alive, or DNF (not found in tube, so assumed dead). All 1:ve larvae were dried in a conventional oven for 24 horrs at $80^{\circ} \mathrm{C}$ and then weighed. The measured endpoint was the percent change in mean weight of the treatment larvae relative to the mean weight of the control larvae. Because mortality was recorded as 100 percent reduction in weight, the endpoint incorporates both weight change and n'rtality.

\section{Biota}

Biota samples were collected at 12 of the 24 sampling sites. The samples consisted of $t$ ird eggs, juvenile birds, fish, an aquatic-plant species, ant an aquatic-invertebrate species. This section describes the field procedures used to collect the different types of biota samples and the preparation of the samples for laboratory analyses.

Analyses for concentrations of organochlorine compounds in biota samples followed the standard procedures of Mississippi State Chemical Laboratory, Mississippi State, Miss. (Mississippi State University, written commun., 1992). In these procedures, 10 grams of tissue are homogenized and mixed with solvents to extract organic compounds. The extract is concentrate 1 and evaporated to dryness and the lipid content is determined. The sample is then dissolved in petroleum ether, purified, and separated into fractions that are analyzed for different organochlorine compounds. Analytical procedures for the dioxins and furans in biological tissues are the property of Dr. T.O. Tiernan of Wright State University, Day'ton, Ohio, and are available only with written permission.

Analyses for concentrations of trace elements in biota samples followed the standard procedures of Research Triangle Institute, Research Triangle Park, N.C. (written commun., 1992). A tissue sample was first homogenized with a food processor, then subsampled for an array of treatments. One subsample was processed to determine moisture content; then it wa- treated by aciddigestion and analyzed by Inductively Coupled Plasma (ICP) Emission to determine trace-element concentrations. Another subsample was analyzed by Graphite Furnace Atomic Absorption (GFAA) to determine arsenic and selenium concentrations. Another subsample was analyzed by Cold Vapor Atomic Absorption (CVAA) to determine mercury concentrations. 
Eight American coot (Fulica americana) eggs were collected from each of four sample sites, and eight western grebe (Aechmophorus occidentalis) eggs were collected from each of the two known nesting colonies in the east and west arms of Potholes Reservoir (see table 5). Coots were selected because they are one of the few aquatic bird species that nest throughout the study area. Grebes were selected because, as predators of fish, they have a higher risk of exposure to the types of contaminants that bioaccumulate in the food chain. Four of the eight eggs of each species were analyzed for organochlorine compounds, and four were analyzed for trace elements. Although welldeveloped eggs were sought, the coots and grebes nested later in 1992 than is usual and, because of time constraints, it became necessary to collect several eggs that were in early stages of development.

Because mallards (Anas platyrhynchos) are frequently used in contaminant exposure studies, their eggs were selected for collection. Ten mallard eggs were collected only from the Moses Lake south sample site; five of the eggs were analyzed for organochlorine compounds and five were analyzed for trace elements. Eggs were candled (held against a light source to see the contents through the shell) in the field, and only well-developed eggs were collected. Frenchman Hills Wasteway, Wahluke Branch Wasteway Lake, and Saddle Mountain Wasteway were searched for mallard nests, but none were found.

The eggs were refrigerated for up to 4 days between collection and processing. Measurements taken on whole eggs included length, width, weight, and volume (table 27; tables 23 through 32 contain supplemental data and are located at the end of the report). The eggshells were bisected with a clean scalpel, and the contents were emptied into tared, chemically cleansed jars. Embryos were examined for abnormalities and their ages were estimated. Mallard embryos were age-classified according to the guidelines of Caldwell and Snart (1974). Coot and grebe embryos were age-classified into one of the following categories: (1) freshly laid, no limb buds; (2) limb buds present but no feather tracts; (3) feather tracts present but no feathers; (4) feathers present. The egg contents were then frozen in the jars and shipped to the laboratory for further analyses. The eggshells were dried for at least a month, then weighed and measured for thickness. The recorded eggshell thickness, including egg membrane, was a mean of four measurements.
Juvenile coots and western gret es were collected using a shotgun and steel shot. The oldest juveniles available were collected because they world have been exposed to potential ambient contam inants longer than younger birds. Four juvenile coots w'ere collected at each of the same four sites where coot eggs were collected (see table 5). Eight juvenile western grebes were collected in the northern area of Potholes Reservoir. Although it is not known for certain from which of the two known CBP nesting colonies a particular grebe origin?ted, it is likely that juveniles from both colonies were collected.

The bodies of the juvenile birds were placed in plastic bags on ice until they could be exsmined later the same day. Each bird was weighed and examined for external and internal abnormalities. Liver and breast tissues were removed, weighed, placed individually into chemically cleansed jars, and frozen for shipmert to the laboratory. For the four smallest juvenile grebes. breast tissue was composited into two samples of two birds each to obtain a minimum sample weight. Thus, six samples of grebe breast tissue were prepared for analyzes. At the laboratory, liver tissue was analyzed for tra:e elements, and breast tissue was analyzed for organo hlorine compounds. To prevent cross-contamination durirg, preparation, the aluminum foil linings of the dissection trays were changed, gloves were changed, and cissection tools were cleaned with acetone, nitric acid, and distilled water between dissections.

\section{Fish}

Three species of fish were collected for chemical analyses: longnose suckers (Catostomus catostomus), carp (Cyprinus carpio), and yellow perch (Perca flavescens) (see table 5). Longnose suckers and carp were selected because their bottom-dwelling lifestyles increase the likelihood of exposure to the types of contaminants associated with bottom sediment. Pe.rch were selected because they are predators and are likely to have a higher risk of exposure to contaminants that bioaccumulate in the food chain. Carp and perch have als' s been collected in previous contaminant studies in the C.BP.

Carp were collected at 11 samp'e sites and yellow perch at 8 sample sites; perch were not available at the 3 Moses Lake sites. These collected fi $h$ were analyzed as 
whole individuals. From each site (except Moses Lake), four individuals of each species were analyzed for organochlorine compounds, and four for trace elements. There were some exceptions, however, concerning the yellow perch samples: (1) only three perch from Winchester Wasteway were analyzed for organochlorine compounds; (2) only three perch from Lind Coulee Wasteway were analyzed for trace elements; (3) one sample from Saddle Mountain Wasteway analyzed for organochlorine compounds was a composite of two small perch; and (4) one analysis for trace elements in a perch from Winchester Wasteway was questionable and not included with the final results.

Because dioxins and furans are present in the Columbia River upstream of the CBP, four longnose suckers were collected from Billy Clapp Lake to determine if these compounds had entered the CBP along with the imported water. Whole individual suckers were analyzed for the presence of the dioxin and furan congeners, TCDD and TCDF. These two compounds make up a large percentage of the total dioxins and furans found in the Columbia River (Johnson and others, 1991a, b).

Fish were captured with variable-mesh gill nets. Nets were usually set in the morning and checked every 1 or 2 hours until all samples had been collected. Occasionally, nets were left set overnight. Sample fish were placed in a holding cooler and processed on shore. The fish were rinsed with stream water, weighed, measured for length, wrapped in aluminum foil and then in plastic, and kept on ice until they could be frozen later the same day. The measuring tape and fish-handler's hands were washed between collections, and the holding cooler was washed between sites.

\section{Plants}

Three samples of sago pondweed (Potamogeton pectinatus) were collected from each of six sample sites and analyzed for trace elements (see table 5). This species was chosen for collection because it is found throughout the study area. Samples were collected by hand in shallow water and with a rake in deep water. Each sample consisted of approximately 100 grams of plant material that might contain one or more individual plants. Roots and flowers or seeds of the pondweed were included in all of the samples. Samples were rinsed and picked carefully to remove sediment, invertebrates, and other foreign matter; then they were weighed, wrapped in aluminum foil and in plastic, and kept on ice until they could be frozen later the same day.

\section{Invertebrates}

Three samples of snails were co!lected from each of three sample sites (see table 5) and analyzed for trace elements. Snails were selected for samp'ing because their population numbers were large enough for efficient collection. The snails were picked by hand from rocks and veg. etation, placed in a stainless steel sieve to drain, and then put into a tared, chemically cleansed jar. A minimum sample weight of 10 grams was collected. The snail samples were a mix of species and sizes; however, predominant species at all sites were Lymnaea palustris and Physa sp. Samples were kept on ice and frozen later the same day.

\section{QUALITY-ASSURANCE PRTCEDURES}

Quality assurance of surface-water samples was based on duplicate and split samples, as well as field blanks of deionized water. All quality-assurance samples were analyzed for the same characteri tics as the environmental samples. During the pre- and post-irrigation seasons, the lake-sampling team collected either duplicate or split samples. During mid-irrigation season, both the lake- and stream-sampling teams collected duplicate samples. Both teams processed at least on? field blank sample during each of the three sampling trips. The type and number of quality-assurance samples collected during the study are shown in table 8.

Results of the analyses of replicate samples show little or no difference in constituent concentrations between each member of the duplicate or the sprit-sample pairs. The lack of major differences in chem istry between the duplicate samples indicates that data variation due to field-collection, sample-handling, and laboratory methods was small. Results of duplicate-sample analyses are included with the environmental-sample analyses of water-quality data in tables 23 and 24 at the end of the report.

Analyses of eight field blank samples indicate that sample collection and analytical procedures were generally free of contamination. Trace amo'nts of ammonia, nitrogen, and chloride were occasionally detected in the blank water (table 9). Although most of the blank samples were free of trace elements, two had zinc concentrations near the analytical reporting limit, and one had a mercury concentration equal to the analytical reporting limit. During the non-irrigation season, the blank samples were usually free of pesticides and organic compounds except for two detections of lindane and one detection of 
Table 8.--Type and number of water-quality assurance samples collected during the study, 1991-92 $[--$, no data]

\begin{tabular}{|c|c|c|c|c|}
\hline Date & Season & $\begin{array}{l}\text { Site name and } \\
\text { (map identifier, } \\
\text { fig. 9) }\end{array}$ & $\begin{array}{l}\text { Replicate- } \\
\text { sample type }\end{array}$ & $\begin{array}{l}\text { Numb of field blank } \\
\text { samples processed } \\
\text { and sampling team }\end{array}$ \\
\hline $11 / 19 / 91$ & Post-irrigation & -- & -- & 1, stream \\
\hline $11 / 20 / 92$ & Post-irrigation & Sand Hollow Creek (SHCb) & Duplicate & 1, lake \\
\hline 03/03/92 & Pre-irrigation & -- & -- & 1, stream \\
\hline 03/03/92 & Pre-irrigation & $\begin{array}{l}\text { Potholes Reservoir on } \\
\text { west arm (PRW) }\end{array}$ & Split & 1, lake \\
\hline $07 / 15 / 92$ & Mid-irrigation & Winchester Wasteway (WW) & Duplicate & 1, stream \\
\hline $07 / 15 / 92$ & Mid-irrigation & $\begin{array}{l}\text { Potholes Reservoir on } \\
\text { east arm (PRE) }\end{array}$ & Duplicate & 1, lake \\
\hline 07/17/92 & Mid-irrigation & -- & -- & 1, stream \\
\hline $07 / 17 / 92$ & Mid-irrigation & -- & -- & 1, lake \\
\hline
\end{tabular}

Table 9.--Results of analyses for inorganic constituents in blank-water samples prepared during sample collection in November 1991, March 1992, and July 1992

[mg/L, milligrams per liter; $\mu \mathrm{g} / \mathrm{L}$, micrograms per liter; <, less than; --, no data]

\begin{tabular}{|c|c|c|c|c|c|c|c|c|c|c|c|}
\hline Date & $\begin{array}{l}\text { Calcium } \\
(\mathrm{mg} / \mathrm{L})\end{array}$ & $\begin{array}{l}\text { Mag- } \\
\text { nesium } \\
(\mathrm{mg} / \mathrm{L})\end{array}$ & $\begin{array}{l}\text { Sodium } \\
(\mathrm{mg} / \mathrm{L})\end{array}$ & $\begin{array}{l}\text { Potas- } \\
\text { sium } \\
(\mathrm{mg} / \mathrm{L})\end{array}$ & $\begin{array}{l}\text { Sul- } \\
\text { fate } \\
\text { (mg/L) }\end{array}$ & $\begin{array}{l}\text { Chlo- } \\
\text { ride } \\
\text { (mg/L) }\end{array}$ & $\begin{array}{l}\text { Fluo- } \\
\text { ride } \\
\text { (mg/L) }\end{array}$ & $\begin{array}{l}\text { Dis- } \\
\text { solved } \\
\text { solids, } \\
\text { residue } \\
\text { at } 180 \\
\text { degrees } \\
\text { Celsius } \\
\text { (mg/L) }\end{array}$ & $\begin{array}{l}\text { Nit- } \\
\text { rite }+ \\
\text { nitrate } \\
\text { nitro- } \\
\text { gen } \\
(\mathrm{mg} / \mathrm{L})\end{array}$ & $\begin{array}{l}\text { Am- } \\
\text { monia } \\
\text { nitro- } \\
\text { gen } \\
(\mathrm{mg} / \mathrm{L})\end{array}$ & $\begin{array}{l}\text { Ortho- } \\
\text { phos- } \\
\text { phorus } \\
\text { (mg/L) }\end{array}$ \\
\hline $\begin{array}{l}11-19-91 \\
11-20-91 \\
03-03-92 \\
03-03-92\end{array}$ & $\begin{array}{r}0.03 \\
<0.02 \\
<0.02 \\
0.40\end{array}$ & $\begin{array}{r}<0.01 \\
<0.01 \\
<0.01 \\
0.17\end{array}$ & $\begin{array}{r}<0.20 \\
<0.20 \\
<0.20 \\
0.40\end{array}$ & $\begin{array}{l}<0.10 \\
<0.10 \\
<0.10 \\
<0.10\end{array}$ & $\begin{array}{l}<0.10 \\
<0.10 \\
<0.10 \\
<0.10\end{array}$ & $\begin{array}{c}<0.10 \\
<0.10 \\
0.20 \\
4.0\end{array}$ & $\begin{array}{l}<0.10 \\
<0.10 \\
<0.10 \\
<0.10\end{array}$ & $\begin{array}{r}24 \\
5 \\
8 \\
3\end{array}$ & $\begin{array}{r}0.050 \\
<0.050 \\
<0.050 \\
<0.050\end{array}$ & $\begin{array}{r}<0.010 \\
0.010 \\
<0.010 \\
<0.010\end{array}$ & $\begin{array}{r}0.010 \\
<0.010 \\
<0.010 \\
<0.010\end{array}$ \\
\hline $\begin{array}{l}07-15-92 \\
07-15-92 \\
07-17-92 \\
07-17-92\end{array}$ & $\begin{array}{r}<0.02 \\
<0.02 \\
<0.02 \\
0.05\end{array}$ & $\begin{array}{l}<0.01 \\
<0.01 \\
<0.01 \\
<0.01\end{array}$ & $\begin{array}{l}<0.20 \\
<0.20 \\
<0.20 \\
<0.02\end{array}$ & $\begin{array}{l}<0.10 \\
<0.10 \\
<0.10 \\
<0.10\end{array}$ & $\begin{array}{l}0.20 \\
0.20 \\
0.10 \\
0.20\end{array}$ & $\begin{array}{l}0.60 \\
0.60 \\
0.40 \\
3.9\end{array}$ & $\begin{array}{l}<0.10 \\
<0.10 \\
<0.10 \\
<0.10\end{array}$ & $\begin{array}{r}<1 \\
3 \\
2 \\
<1\end{array}$ & $\begin{array}{l}<0.050 \\
<0.050 \\
<0.050 \\
<0.050\end{array}$ & $\begin{array}{l}<.010 \\
0.010 \\
0.030 \\
0.040\end{array}$ & $\begin{array}{l}<0.010 \\
<0.010 \\
<0.010 \\
<0.010\end{array}$ \\
\hline Date & $\begin{array}{l}\text { Arsenic } \\
(\mu \mathrm{g} / \mathrm{L})\end{array}$ & $\begin{array}{l}\text { Boron } \\
(\mu g / L)\end{array}$ & $\begin{array}{l}\text { Cad- } \\
\text { mium } \\
(\mu g / L)\end{array}$ & $\begin{array}{l}\text { Chro- } \\
\text { mium } \\
(\mu g / L)\end{array}$ & $\begin{array}{l}\text { Lead } \\
(\mu g / L)\end{array}$ & $\begin{array}{l}\text { Mer- } \\
\text { cury } \\
(\mu g / L)\end{array}$ & $\begin{array}{l}\text { Molyb- } \\
\text { denum } \\
(\mu \mathrm{g} / \mathrm{L})\end{array}$ & $\begin{array}{l}\text { Sele- } \\
\text { nium } \\
(\mu g / L)\end{array}$ & $\begin{array}{l}\text { Vana- } \\
\text { dium } \\
(\mu g / L)\end{array}$ & $\begin{array}{l}\text { Zinc } \\
(\mu g / L)\end{array}$ & $\begin{array}{l}\text { Total } \\
\text { natural } \\
\text { uranium } \\
(\mu \mathrm{g} / \mathrm{L})\end{array}$ \\
\hline $\begin{array}{l}11-19-91 \\
11-20-91 \\
03-03-92 \\
03-03-92\end{array}$ & $\begin{array}{l}<1 \\
<1 \\
<1 \\
<1\end{array}$ & $\begin{array}{l}<10 \\
<10 \\
<10 \\
<10\end{array}$ & $\begin{array}{l}<1.0 \\
<1.0 \\
<1.0 \\
<1.0\end{array}$ & $\begin{array}{l}<1 \\
<1 \\
<1 \\
<1\end{array}$ & $\begin{array}{l}<1 \\
<1 \\
<1 \\
<1\end{array}$ & $\begin{array}{r}<0.1 \\
0.1 \\
<0.1 \\
<0.1\end{array}$ & $\begin{array}{l}<1 \\
<1 \\
<1 \\
<1\end{array}$ & $\begin{array}{l}<1 \\
<1 \\
<1 \\
<1\end{array}$ & $\begin{array}{l}<1 \\
<1 \\
<1 \\
<1\end{array}$ & $\begin{array}{r}4 \\
<3 \\
<3 \\
4\end{array}$ & $\begin{array}{l}- \\
-- \\
-- \\
-\end{array}$ \\
\hline $\begin{array}{l}07-15-92 \\
07-15-92 \\
07-17-92 \\
07-17-92\end{array}$ & $\begin{array}{l}<1 \\
<1 \\
<1 \\
<1\end{array}$ & $\begin{array}{l}<10 \\
<10 \\
<10 \\
<10\end{array}$ & $\begin{array}{l}<1.0 \\
<1.0 \\
<1.0 \\
<1.0\end{array}$ & $\begin{array}{l}<1 \\
<1 \\
<1 \\
<1\end{array}$ & $\begin{array}{l}<1 \\
<1 \\
<1 \\
<1\end{array}$ & $\begin{array}{r}<0.1 \\
<0.1 \\
<0.1 \\
0.1\end{array}$ & $\begin{array}{l}<1 \\
<1 \\
<1 \\
<1\end{array}$ & $\begin{array}{l}<1 \\
<1 \\
<1 \\
<1\end{array}$ & $\begin{array}{l}<1 \\
<1 \\
<1 \\
<1\end{array}$ & $\begin{array}{l}<3 \\
<3 \\
<3 \\
<3\end{array}$ & $\begin{array}{l}<1.0 \\
<1.0 \\
<1.0 \\
<1.0\end{array}$ \\
\hline
\end{tabular}


dieldrin--both concentrations were equal to the analytical reporting limits. During the irrigation season, the blank samples were free of all pesticides and organic compounds except for one detection of 2,4-D in the blank processed at Wahluke Branch 10A Wasteway. The 2,4-D concentration in this blank was greater than 2,4-D concentrations in the two environmental samples collected at wasteway sites that day. Apparently, 2,4-D was widespread throughout the area in July because it was detected in 19 of the 21 environmental water samples collected during the month (see table 24, end of the report). Because of the large concentration in the blank sample and the prevalence of 2,4-D in the study area, the blank sample probably was contaminated during preparation, possibly by dust or vapor. Results of the blank-sample analysis does not show 2,4-D cross-contamination between the two environmental samples collected on the same day.

One set of duplicate bottom-sediment samples was collected. Differences between the duplicate constituent concentrations were small (see tables 27 and 28, end of the report) and indicate that variation in data due to fieldcollection, sample-handling, and laboratory methods was negligible. In addition, a reference material was tested for trace-element concentrations along with the environmental samples; the analytical results show concentrations within the acceptable range for the particular elements.

In the Microtox bioassay, pipetting could introduce error and affect data quality. Pipetting error was assessed in duplicated tests by comparing light levels in two control test tubes containing bacteria but no sample water. $\mathbf{A}$ maximum difference of no more than 20 percent between light-level readings of pairs of controls is considered acceptable (Microbics Corporation, 1992). Of 51 tests, 35 were run in duplicate, and only 4 of 35 pairs of controls showed a greater-than-20-percent difference in light level. The majority ( 57 percent) of the pairs of controls showed less than 10 percent difference. In addition, a phenol standard is used to determine if all aspects of the test are run correctly, and if the Microtox bacteria demonstrate a typical response. The phenol standard was tested at the beginning of each of the three sampling periods. Toxicities of all the phenol tests were within the range of toxicities demonstrated for the Microtox bacteria.

The daphnid bioassay exposed Daphnia magna to control water and reference toxicants. The control water was a USEPA moderately-hard formulation (about $180 \mathrm{mg} / \mathrm{L}$ as $\mathrm{CaCO}_{3}$ ). Two reference tests per sample collection period were run concurrently with samples to detect changes in daphnid sensitivity; sodium chloride was used as the reference toxicant. Daphnids exposed to the reference toxicant showed either a typi $; a l$ response or a slightly greater than average sensitivity (Toxscan Inc., 1991, 1992a, b).

For the chironomid bioassay, the toxicity-testing procedure exposed chironomids to a control composed of a reference material. The reference material was assured to be free of contaminants. Also, larvae v'ere added to test tubes in a systematic fashion, which minimized size selection bias for any particular sample (Herry and Jaschke, no date).

For analyses of organochlorine compounds and trace elements in biota tissues, the quality-as vrance procedures of the Mississippi State Chemical Labcratory and Research Triangle Institute consisted of procedural blanks, duplicates, analyses of reference mater:als, and determination of the percent recovery of spiked samples. The quality-assurance results from both of these laboratories were examined and determined to be acceptrble by the quality-assurance officer of USFWS Patuxent Analytical Control Facility.

Samples collected August 5, 1992., for dioxin and furan analyses were shipped by overniçht carrier and arrived in good condition at Wright State University, Dayton, Ohio, the next day. Samples v'ere extracted within 7 days and analyzed within 21 diys. A laboratory blank was analyzed, and no dioxin compounds were detected. The percent recovery of one surrogate and two internal standards ranged from 35- to 77-percent recovery with a mean recovery of 57-percent. T iese recovery values are typical for this type of analysis; reported results were corrected for recovery. No duplicate analyses were performed.

\section{DISCUSSION OF RESULTS}

The reconnaissance investigation provided data about concentrations of selected organi: and inorganic constituents in water, bottom sediment, and biota in the CBP. Existing Federal or State guidelines, either legally enforceable standards or recommended criteria, and published baseline values served as references for comparing observed concentrations of constituents. Baseline values were used as background conditions to evaluate the significance of the concentrations of constituents for which standards or criteria are not available. Con -tituent concentrations were referred to as elevated when exceeding on the basis of published standards, criteri values. The following discussions inclide statistical and interpretive summaries of water-quality properties and 
chemical concentrations in water, bottom sediment, and biota collected at sampling sites during the three periods of data collection. Statistical summaries of data with values less than the reporting limit were calculated with the multiple detection-limit procedures developed by Helsel and Cohn (1988). All data collected during the study are in tables at the end of the report; tables 25 through 28 list analytical results for water and bottom-sediment samples, and tables 29 through 34 list analytical results for biological samples.

\section{Characteristics of Sampled Water}

Presented below and summarized in table 10 are the results of field measurements and laboratory analysis of water samples from the CBP. Table 11 lists drinking water standards and criteria for the protection of freshwater aquatic life for selected properties and constituents determined during the study. Field observations, such as $\mathrm{pH}$ and dissolved oxygen, and the concentrations of dissolved solids, trace elements, and organic compounds in water samples are discussed in this section.

\section{Field Measurements}

Field measurements were made of water temperature, specific conductance, dissolved oxygen, alkalinity, and $\mathrm{pH}$. Water temperature affects the growth and health of periphyton, benthic invertebrate, and fish populations, and is directly related to the solubility of oxygen in water. Certain life stages of cold-water species of fish such as salmon, rainbow trout, and brook trout are adversely affected if weekly average temperatures are greater than about $18^{\circ} \mathrm{C}$; warm-water species of fish such as black crappie and bass are adversely affected by temperatures greater than $27^{\circ} \mathrm{C}$ (U.S. Environmental Protection Agency, 1976). During the study, the maximum water temperature observed was $25.0^{\circ} \mathrm{C}$ in July at Lower Crab Creek at McManamon Road (see table 10).

To protect and maintain fish populations, the USEPA (1976) recommends a minimum concentration of $5.0 \mathrm{mg} / \mathrm{L}$ dissolved oxygen. Dissolved-oxygen concentrations in the lakes were from less than $1 \mathrm{mg} / \mathrm{L}$ in the hypolimnion in July to $17.9 \mathrm{mg} / \mathrm{L}$ in the upper part of the water column in March. Dissolved-oxygen concentrations in streams and wasteways were from 7.8 to $13.5 \mathrm{mg} / \mathrm{L}$, with a median value of $11.2 \mathrm{mg} / \mathrm{L}$. Dissolved-oxygen measurements were made only during the day under conditions of active photosynthesis; no measurements were made at night when concentrations are typically low.
Alkalinity buffers $\mathrm{pH}$ changes in water, some of which can occur naturally as a result of photosynthetic processes. Also, the carbonate and bicarbonate components of alkalinity can form complexer with certain metals and reduce their toxicity (U.S. Enviroymental Protection Agency, 1976). During the study, alkalinities in water samples were from 58 to $359 \mathrm{mg} / \mathrm{L}$. All observations were above the minimum value of $20 \mathrm{mg} / \mathrm{L}$ (see table 11 ) recommended to protect the health of fre ?hwater organisms (U.S. Environmental Protection Agen :y, 1986).

The $\mathrm{pH}$ of the water is important biologically because it can affect the solubility and toxicity of different compounds, especially metals. The USEPA (1986) recommends a range of $\mathrm{pH}$ from 6.5 to 9.0 to protect freshwater fish and aquatic benthic invertel rates and a range of $\mathrm{pH}$ from 4.5 to 9.0 in irrigation water to protect crops (see table 11). In this study, the $\mathrm{pH}$ of water samples ranged from 7.8 to 9.2. High $\mathrm{pH}$ values obse ved in all samples collected from Moses Lake were probably due in part to photosynthetic removal of carbon dioxide from the water by large standing crops of phytoplank`on.

\section{Dissolved Solids, Major Ions, and Nutrients}

Dissolved solids in fresh water c onsist of various dissolved materials, including inorganic salts in ionic form and small amounts of organic matter. In irrigation water, the dissolved-solids concentration and the proportions of the different cations can affect the osmotic properties of plants. Concentrations between 500 and $1,000 \mathrm{mg} / \mathrm{L}$ in irrigation water can adversely affect some types of crops (U.S. Environmental Protection Agen:y, 1976). In this study, dissolved-solids concentrations exceeded $500 \mathrm{mg} / \mathrm{L}$ only in samples from Wahluke Brancl 10A Wasteway, Crab Creek near Beverly, and EL68D Wasteway during non-irrigation season.

Concentrations of dissolved constituents varied spatially and seasonally. They generally increased in a downstream direction that corresponded to water reuse as the water moves through the irrigation project. For example, from Billy Clapp Lake, with an average of $87 \mathrm{mg} / \mathrm{L}$, average dissolved-solids concentrations in reased to $310 \mathrm{mg} / \mathrm{L}$ in Potholes Reservoir, to $452 \mathrm{mg} / \mathrm{L}$ in Crab Creek near Beverly, and to $512 \mathrm{mg} / \mathrm{L}$ in Wahluke Branch $10 \mathrm{~A}$ Wasteway. Concentrations during non-irrigation season tended to be larger than during irrigation season (fig. 10), and were probably due in part to a larger dissolved-solids content in ground water, which sustains baseflows during non-irrigation season. For example, Pocky Ford Creek and Upper Crab Creek, which have a large ground-water 
Table 10.--Summary of properties and inorganic-constituent concentrations in water samples collect 9 from the Columbia Basin Project in November 1991, March 1992, and July 1992

[Concentrations are dissolved; $\mathrm{mg} / \mathrm{L}$, milligrams per liter; $\mu \mathrm{g} / \mathrm{L}$, micrograms per liter; ${ }^{\circ} \mathrm{C}$, degrees $\mathrm{Ce}$ 'sius; $\mu \mathrm{S} / \mathrm{cm}$, microsiemens per centimeter at $25^{\circ} \mathrm{C} ; \mathrm{CaCO}_{3}$, calcium carbonate; $\mathrm{HCO}_{3}$, bicarbonate; $\mathrm{CO}_{3}$, carbonate; <, less than; - , no data]

\begin{tabular}{|c|c|c|c|c|c|}
\hline \multirow[b]{2}{*}{ Constituent or property } & \multirow{2}{*}{$\begin{array}{l}\text { Number } \\
\text { of } \\
\text { samples }\end{array}$} & \multicolumn{3}{|c|}{ Values } & \multirow{2}{*}{$\begin{array}{l}\text { Reference- } \\
\text { site } \\
\text { value }^{a}\end{array}$} \\
\hline & & Minimum & Maximum & Median & \\
\hline \multicolumn{6}{|l|}{ Field measurements: } \\
\hline Specific conductance $(\mu \mathrm{S} / \mathrm{cm})$ & 51 & 133 & 982 & 387 & 136 \\
\hline $\mathrm{pH}$ & 51 & 7.8 & 9.2 & 8.5 & 8.1 \\
\hline Temperature $\left({ }^{\circ} \mathrm{C}\right)$, lakes & 18 & 4.0 & 23.0 & -- & $b_{4.0-15.0}$ \\
\hline Temperature $\left({ }^{\circ} \mathrm{C}\right)$, streams & 33 & 5.5 & 25.0 & 10.5 & -- \\
\hline Dissolved oxygen (mg/L), lakes & 18 & $<1$ & 17.9 & -- & $c_{2.2-8.3}$ \\
\hline Dissolved oxygen (mg/L), streams & 33 & 7.8 & 13.5 & 11.2 & -- \\
\hline \multicolumn{6}{|l|}{ Major ions: } \\
\hline Hardness $\left(\mathrm{mg} / \mathrm{L}\right.$ as $\mathrm{CaCO}_{3}$ ) & 51 & 62 & 340 & 160 & 65 \\
\hline Calcium (mg/L) & 51 & 18 & 81 & 36 & 19 \\
\hline Magnesium (mg/L) & 51 & 4.1 & 38 & 16 & 4.3 \\
\hline Sodium $(\mathrm{mg} / \mathrm{L})$ & 51 & 2.2 & 95 & 25 & 2.2 \\
\hline Potassium $(\mathrm{mg} / \mathrm{L})$ & 51 & 0.7 & 13 & 4.3 & 0.80 \\
\hline Bicarbonate $\left(\mathrm{mg} / \mathrm{L}\right.$ as $\left.\mathrm{HCO}_{3}\right)$ & 51 & 73 & 439 & 197 & 73 \\
\hline Carbonate $\left(\mathrm{mg} / \mathrm{L}\right.$ as $\left.\mathrm{CO}_{3}\right)$ & 51 & $\mathbf{0}$ & 17 & 7 & 0 \\
\hline Alkalinity ( $\mathrm{mg} / \mathrm{L}$ as $\mathrm{CaCO}_{3}$ ) & 51 & 58 & 359 & 165 & 62 \\
\hline Sulfate $(\mathrm{mg} / \mathrm{L})$ & 51 & 8.6 & 130 & 30 & 9.8 \\
\hline Chloride (mg/L) & 51 & 1.0 & 41 & 9.8 & 1.5 \\
\hline Fluoride (mg/L) & 51 & 0.1 & 0.7 & 0.4 & 0.1 \\
\hline Dissolved solids (mg/L) & 51 & 82 & 615 & 249 & 88 \\
\hline Nitrite plus nitrate (mg/L as $N$ ) & 51 & $<0.05$ & 12 & 1.7 & $<0.05$ \\
\hline Ammonia (mg/L as $\mathrm{N}$ ) & 51 & $<0.1$ & 0.62 & 0.02 & 0.02 \\
\hline Orthophosphorus (mg/L) & 51 & $<0.01$ & 0.42 & 0.01 & $<0.01$ \\
\hline \multicolumn{6}{|l|}{ Trace elements: } \\
\hline Arsenic $(\mu \mathrm{g} / \mathrm{L})$ & 51 & $<1$ & 12 & 3 & $<1$ \\
\hline Boron $(\mu \mathrm{g} / \mathrm{L})$ & 51 & $<10$ & 150 & 20 & $<10$ \\
\hline Cadmium $(\mu g / L)$ & 51 & $<1.0$ & $<1.0$ & $<1.0$ & $<1$ \\
\hline Chromium $(\mu \mathrm{g} / \mathrm{L})$ & 51 & $<1$ & 10 & $<1$ & $<1$ \\
\hline Copper $(\mu \mathrm{g} / \mathrm{L})$ & 51 & $<1$ & 5 & 0.7 & 1 \\
\hline Lead $(\mu \mathrm{g} / \mathrm{L})$ & 51 & $<1$ & $d_{29}$ & $<1$ & $<1$ \\
\hline Mercury $(\mu \mathrm{g} / \mathrm{L})$ & 51 & $<0.1$ & $d_{3}$ & $<0.1$ & $<0.1$ \\
\hline Molybdenum $(\mu \mathrm{g} / \mathrm{L})$ & 51 & $<1$ & 7 & 2 & $<1$ \\
\hline Selenium $(\mu \mathrm{g} / \mathrm{L})$ & 51 & $<1$ & 4 & $<1$ & $<1$ \\
\hline Vanadium $(\mu \mathrm{g} / \mathrm{L})$ & 51 & 1 & 37 & 12 & 1 \\
\hline $\operatorname{Zinc}(\mu \mathrm{g} / \mathrm{L})$ & 51 & $<3$ & 13 & 3.7 & $<3$ \\
\hline \multicolumn{6}{|l|}{ Radio chemicals: } \\
\hline Uranium $(\mu \mathrm{g} / \mathrm{L})$ & 21 & 1.2 & 5.9 & 2.4 & ${ }^{e} 1.4$ \\
\hline
\end{tabular}

\footnotetext{
${ }^{\mathrm{a}}$ Median of three samples collected from Billy Clapp Lake.

${ }^{b}$ Minimum and maximum average water column temperatures.

${ }^{\mathrm{c}}$ Minimum and maximum concentrations in the water column in July 1992.

${ }^{d}$ Reported value is suspected to be inaccurate; next largest value for lead was 3 micrograms per liter, and for mercury, 0.6 micrograms per liter.

${ }^{\mathrm{e}}$ Single-sample value.
} 
Table 11.--Drinking water standards and water-quality criteria of selected constituents and properties for the protection of freshwater aquatic life and for the purposes of irrigation and livestock watering

[Concentrations in micrograms per liter unless specified. MCL, Maximum Contaminant Level; SMCL, Seconcary Maximum Contaminant Level; $\mathrm{mg} / \mathrm{L}$, milligrams per liter, $\mathrm{CaCO}_{3}$, calcium carbonate; >, actual value is greater than shown; <, actual value is less than shown; --, no criterion or standard available]

\begin{tabular}{|c|c|c|c|c|c|}
\hline Constituent or property & $\frac{\text { Drink }}{\mathrm{MCL}}$ & ng Water & Aquatic life & Irrigation & $\begin{array}{l}\text { Livestock } \\
\text { watering }\end{array}$ \\
\hline pH (units) & -- & 6.5 to 8.5 & ${ }^{2 \mathrm{a}} 6.5$ to 9.0 & ${ }^{2 \mathrm{~d}} 4.5$ to 9.0 & -- \\
\hline Alkalinity as $\mathrm{CaCO}_{3}(\mathrm{mg} / \mathrm{L})$ & -- & -- & $2 \mathrm{a}>20$ & -- & -- \\
\hline Dissolved solids (mg/L) & -- & 500 & -. & ${ }^{2 d} 500$ & -- \\
\hline Sulfate $(\mathrm{mg} / \mathrm{L})$ & -- & 250 & -- & .. & -- \\
\hline Chloride (mg/L) & - & 250 & -. & -- & -- \\
\hline Fluoride $(\mathrm{mg} / \mathrm{L})$ & ${ }^{16} 4$ & 2 & -- & -- & -- \\
\hline $\begin{array}{l}\text { Nitrite plus nitrate } \\
\text { (mg/L as nitrogen) }\end{array}$ & ${ }^{1 b} 10$ & - & -- & -- & -- \\
\hline Arsenic & ${ }^{1 b_{50}}$ & -. & ${ }^{2 b} 190$ and 360 & ${ }^{7} 100$ & ${ }^{7} 200$ \\
\hline Boron & - & -- & -- & ${ }^{2 d} 750$ & 75,000 \\
\hline Cadmium & $\mathrm{lb}_{5}$ & -- & $2 b .61 .1$ and 3.9 & ${ }^{7} 10$ & 750 \\
\hline Chromium & ${ }^{1 b} 100$ & -- & $2 b, 6210$ and 1,700 & ${ }^{7} 100$ & ${ }^{7} 1,000$ \\
\hline Copper & ${ }^{3} 1,300$ & 1,000 & $2 b, 612$ and 18 & ${ }^{7} 200$ & 3500 \\
\hline Lead & $\mathrm{lb}_{50}$ & -- & $2 b, 63.2$ and 82 & 75,000 & $7_{100}$ \\
\hline Mercury(II) & $\mathrm{db}_{2}$ & -- & ${ }^{2 b} 0.012$ and 2.4 & - & $\overline{7}_{10}$ \\
\hline Molybdenum & -- & -- & ${ }^{8} 200$ & ${ }^{7} 10$ & -- \\
\hline Selenium(IV) & ${ }^{1 b_{50}}$ & -- & ${ }^{5} 5$ and 20 & ${ }^{7} 20$ & ${ }^{7} 50$ \\
\hline Uranium & ${ }^{4} 20$ & -- & - & - & -- \\
\hline Vanadium & -- & -. & -- & ${ }^{7} 100$ & ${ }^{7} 100$ \\
\hline Zinc & -- & 5,000 & $2 b, 6110$ and 120 & ${ }^{7} 2,000$ & ${ }^{7} 25,000$ \\
\hline Chlorpyrifos & -- & -- & ${ }^{2 b} 0.041$ and 0.083 & -- & -- \\
\hline DDE & -- & .- & $2 c_{0} 0.001$ and 1.1 & .- & -- \\
\hline DDT & -- & -- & ${ }^{20} 0.001$ and 1.1 & -- & ${ }^{8} 50$ \\
\hline Dieldrin & .- & .. & ${ }^{2 c} 0.0019$ and 2.5 & -- & ${ }^{8} 1$ \\
\hline Disulfoton & -- & -- & -- & -- & -- \\
\hline Lindane & ${ }^{1 \mathrm{~b}} .2$ & -- & ${ }^{20} 0.08$ and 2.0 & -- & 85.0 \\
\hline Malathion & -- & -- & $2 a .1$ & -- & -- \\
\hline Methoxychlor & ${ }^{1 b} 40$ & -- & ${ }^{2 \mathrm{a}} 0.03$ & .- & ${ }^{8} 1,000$ \\
\hline Methyl parathion & -- & -- & -- & .- & -- \\
\hline Dicamba & -- & -- & -- & -- & -- \\
\hline Picloram & ${ }^{3} 500$ & -- & -- & -- & -- \\
\hline 2,4-D & ${ }^{1} b_{70}$ & -- & -- & -- & -- \\
\hline
\end{tabular}

${ }^{1}$ U.S. Environmental Protection Agency (1992a).

"Secondary Maximum Contaminant Level.

h Maximum Contaminant Level.

${ }^{2}$ U.S. Environmental Protection Agency (1986).

a 24-hour freshwater chronic criterion.

${ }^{b}$ Freshwater aquatic-life criteria: first value is chronic, 4-day average concentration once every 3 years; second value is acute, 1-hour average concentration once every 3 years.

${ }^{c}$ First value is 24 -hour chronic criterion and second value should not be exceeded at any time.

${ }^{d}$ Criteria for long-term irrigation of sensitive crops.

${ }^{3}$ Proposed Maximum Contaminant Level (U.S. Environmental Protection Agency, 1991a).

${ }^{4}$ Proposed Maximum Contaminant Level (U.S. Environmental Protection Agency, 1991b).

${ }^{5}$ U.S. Environmental Protection Agency (1987): first value is chronic; second value is acute.

${ }^{6}$ Based on water hardness of $100 \mathrm{mg} / \mathrm{L}$.

${ }^{7}$ National Academy of Sciences and National Academy of Engineering (1973).

${ }^{8}$ Environment Canada (1979). 


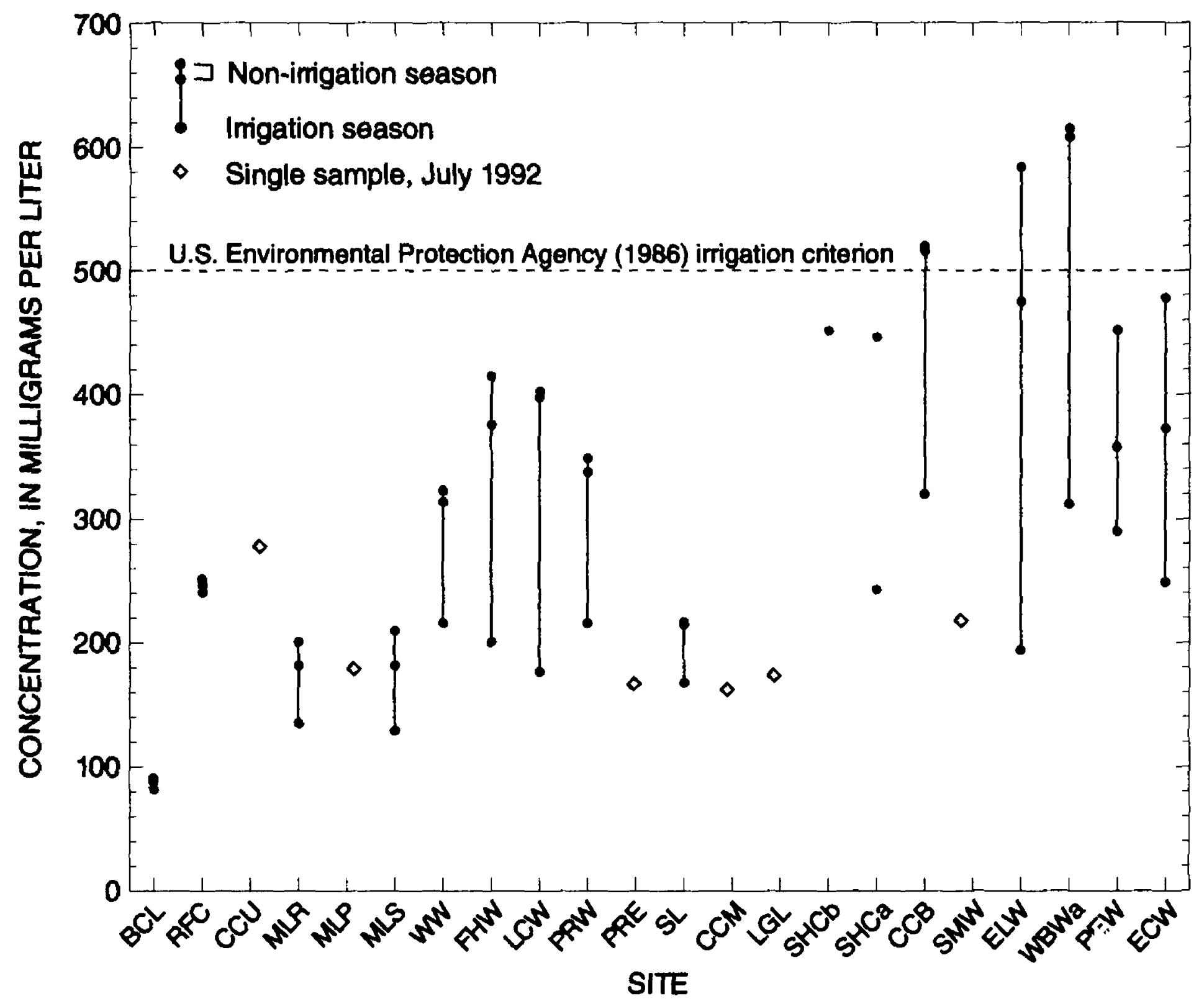

Figure 10.--Concentrations of dissolved solids in water samples from the Columbia Basin Project, November 1991, March 1992, and July 1992. Site abbreviation is map identifier (fig.9); se text page 22 for explanation of map identifiers. 
component, had average dissolved-solids concentrations of $247 \mathrm{mg} / \mathrm{L}$ and $275 \mathrm{mg} / \mathrm{L}$, respectively. Median concentrations of the major ions that constitute the dissolved solids were all greater than the median concentrations for Billy Clapp Lake, the reference site (see table 10).

In agriculture, sodium can affect the structure and permeability of soils and is toxic to some plants. Sodium levels for irrigation purposes are usually evaluated with respect to the sodium adsorption ratio (SAR) calculated according to the following equation (Hem, 1989):

$$
\mathrm{SAR}=\frac{\left(\mathrm{Na}^{+}\right)}{\sqrt{1 / 2\left[\left(\mathrm{Ca}^{2+}\right)+\left(\mathrm{Mg}^{2+}\right)\right]}},
$$

where $\mathrm{Na}^{+}, \mathrm{Ca}^{2+}$, and $\mathrm{Mg}^{2+}$ concentrations are expressed in milliequivalents per liter. For sensitive fruits, the sodium tolerance is a SAR of no more than about 4 . For less-sensitive crops and forages, the tolerance is a range of SARs from about 8 to 18, depending on local soil conditions (U.S. Environmental Protection Agency, 1976). Although sodium concentrations in the study area were as large as $95 \mathrm{mg} / \mathrm{L}$ (at Wahluke Branch $10 \mathrm{~A}$ Wasteway), SAR values did not exceed 2 . SAR values were all within the low sodium hazard classification for irrigation water, but most of the specific conductance values were within the medium salinity hazard classification for irrigation water.

Nitrate concentrations, like dissolved solids, increased in a downstream direction and exhibited seasonal variation. During non-irrigation season, nitrate concentrations at sites such as Sand Hollow Creek, Wahluke Branch 10A Wasteway, EL68D, and Frenchman Hills Wasteways were larger than during irrigation season (fig. 11). Seasonal variation in nitrate concentrations probably indicates that nitrogen from crop fertilizer has leached from the soils into tile drains and the shallow groundwater system and entered the stream channel as baseflow. During irrigation, nitrate concentrations in surface-water samples were small when the large volume of dilute Columbia River water dominated streamflows. Nitrate concentrations observed during the study were small, ranging from less than 0.05 to $12 \mathrm{mg} / \mathrm{L}$. Orthophosphorus concentrations ranged from less than 0.01 to $0.42 \mathrm{mg} / \mathrm{L}$. Only in the March sample from Sand Hollow Creek did a nitrogen concentration exceed USEPA's maximum contaminant level (MCL) of $10 \mathrm{mg} / \mathrm{L}$.
Trace Elements

Trace elements determined in the study included arsenic, boron, selenium, uranium, and several metals. If present in natural water systems, th sse elements are usually found in small concentrations on the order of micrograms per liter. Some trace elements are important micronutrients for plants or animals; however, these same elements can be toxic at elevated concentrations.

Median trace-element concentrations were small, and some were less than analytical reporting limits. Because most of the samples had concentrations that did not exceed various protection criteria for drinking, aquatic life, or irrigation, trace elements in water do not appear to pose a threat to human or wildlife health. Concentrations of chromium, lead, mercury, and se'enium in many of the water samples were less than analytical reporting limits (see table 25). Cadmium concentrations were less than the reporting limit of $1 \mu \mathrm{g} / \mathrm{L}$ in all samples collected. A few trace elements--boron, molybdenum, uranium, and vanadium--were present in water samples collected from the wasteways with large percentages of reused water and the concentrations tended to be larger d'uring non-irrigation season than during irrigation seasor. Although concentrations of some of the trace elements increased in a downstream direction and with water reuse, none exceeded any standards or criteria.

Two factors control and minimize trace-element concentrations in the water of the CBP. (1) The CBP is for the most part a flow-through system with only a few terminus collection ponds or lakes; and (2) the large quantity of imported Columbia River water dil stes the concentrations of constituents that typically accumulate in irrigation drainage.

\section{Boron}

Boron is found in nature as a sodium- or calciumborate salt and as the mineral tourmaline in igneous and granitic rocks (Hem, 1989). Small amounts of boron are essential for plant growth; however. large concentrations in irrigation water or in the soil are harmful to certain plants. Concentrations of boron in water samples from the CBP were considerably less than $7: 9 \mu \mathrm{g} / \mathrm{L}$, the maximum value recommended by USEPA (1SR, ) for the long-term irrigation of sensitive crops. The median value was $20 \mu \mathrm{g} / \mathrm{L}$, and concentrations ranged from less than 10 to $150 \mu \mathrm{g} / \mathrm{L}$. The maximum value was observed in the March sample from Frenchman Hil" ? Wasteway. The next largest value, $100 \mu \mathrm{g} / \mathrm{L}$, was observed in the November 


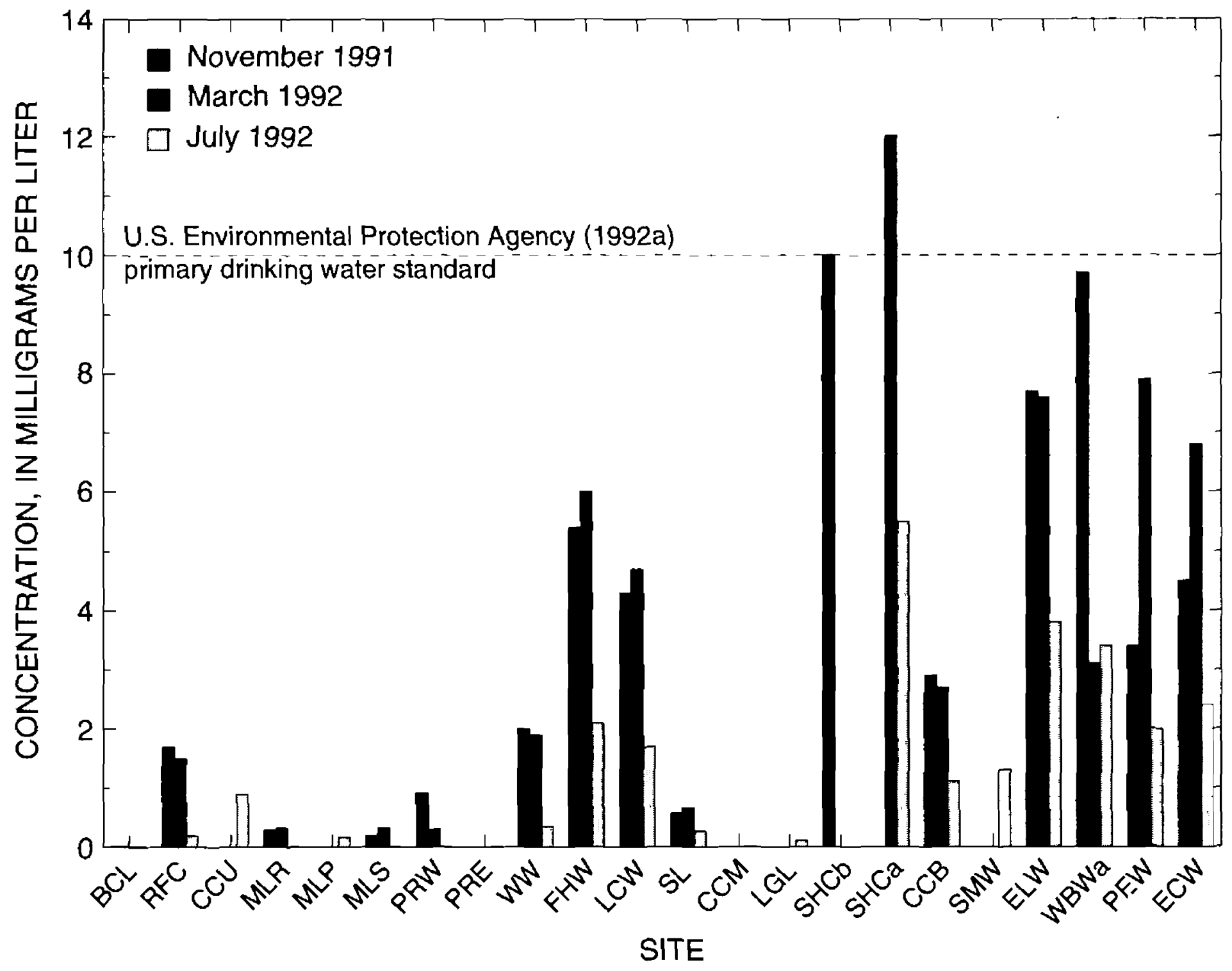

Figure 11.--Dissolved nitrate-nitrogen concentrations in water samples from the Columbia Basin Project, November 1991, March 1992, and July 1992. Site abbreviation is map identifier (fig.9); see text page 22 for explanation of map identifiers. 
sample from Wahluke Branch 10A Wasteway. Boron concentrations increased in a downstream direction that corresponded to water reuse through the irrigation project.

\section{Molybdenum}

Molybdenum occurs naturally in several types of metallic ores and is found in detectable concentrations in surface and ground waters, sediment, and vegetation (Hem, 1989). Molybdenum tends to accumulate in plants in quantities that can adversely affect grazing animals (Dye and O'Hara, 1959); however, it is also an essential element in animal and plant nutrition (Hem, 1989). The USEPA (1986) recommends a maximum value of $10 \mu \mathrm{g} / \mathrm{L}$ for the long-term irrigation of sensitive crops and Environment Canada (1979) recommends a maximum of $200 \mu \mathrm{g} / \mathrm{L}$ for the protection of aquatic life. Natural surface waters not affected by a contamination source typically have molybdenum concentrations of less than $1 \mu \mathrm{g} / \mathrm{L}$ (Hem, 1989). Concentrations in samples from this study were from less than 1 to $7 \mu \mathrm{g} / \mathrm{L}$, with a median value of $2 \mu \mathrm{g} / \mathrm{L}$. Molybdenum concentrations were usually larger in samples collected during the non-irrigation season. Concentrations of $6 \mu \mathrm{g} / \mathrm{L}$ in samples from Lind Coulee Wasteway and $7 \mu \mathrm{g} / \mathrm{L}$ from Wahluke Branch 10A Wasteway during non-irrigation season were diluted to less than $3 \mu \mathrm{g} / \mathrm{L}$ during irrigation season.

\section{Uranium}

Uranium is more abundant in the earth's crust than mercury, antimony, silver, or cadmium and is found in several minerals (CRC Press, 1975). Uranium concentrations in most natural waters range from 0.1 to $10 \mu \mathrm{g} / \mathrm{L}$, but concentrations can exceed $1,000 \mu \mathrm{g} / \mathrm{L}$ in water associated with uranium ore deposits (Hem, 1989). The median concentration of the samples collected in the CBP was $2.4 \mu \mathrm{g} / \mathrm{L}$. Concentrations, from 1.2 to $5.9 \mu \mathrm{g} / \mathrm{L}$, were all less than the USEPA (1991b) MCL of $20 \mu \mathrm{g} / \mathrm{L}$ for drinking water. Uranium concentrations tended to increase in a downstream direction and were largest (more than $4.0 \mu \mathrm{g} / \mathrm{L}$ ) in the southern wasteways: Crab Creek near Beverly, Saddle Mountain Wasteway, Wahluke Branch 10A Wasteway, PE16.4 Wasteway, and Esquatzel Coulee Wasteway.

\section{Vanadium}

Vanadium, an element involved in the biochemistry of living organisms, is present in plants, coal, and petroleum (CRC Press, 1975). In nature, vanadium can be present in minerals containing uraniur. Most surface waters rarely contain vanadium in concentrations greater than $10 \mu \mathrm{g} / \mathrm{L}$ (Hem, 1989). In the CBP, however, concentrations tended to be larger, with the median concentration of $12 \mu \mathrm{g} / \mathrm{L}$ and the range from 1 to $37 \mu \mathrm{g} / \mathrm{L}$. All concentrations of vanadium observed were substantially less than the criterion of $100 \mu \mathrm{g} / \mathrm{L}$ recommended for irrigation water by the National Academy of Sciences and National Academy of Engineering (1973).

Concentrations of vanadium were larger downstream of Billy Clapp Lake, the reference site. Also, concentrations were usually larger in samples co"lected during nonirrigation season than during irrigation season. In ground-water-fed Rocky Ford Creek, vanadium concentrations an order of magnitude larger than in Billy Clapp Lake suggest a source of vanadium is the aquifer materials. The largest concentrations of vanadium (more than $30 \mu \mathrm{g} / \mathrm{L}$ ) were observed in Frenchman Hills, Lind Coulee, EL68D, and PE16.4 Wasteways. Thes? sites also had large concentrations of uranium, suggesting that vanadium and uranium might share a common mineral source within the aquifer materials.

\section{Other Trace Elemerts}

Arsenic is ubiquitous in nature. Most forms of arsenic are toxic to animals and plants, but the trivalent $\left(\mathrm{As}^{3+}\right)$ form is more toxic than the pentavalent $\left(\mathrm{As}^{5+}\right)$ form. For drinking water, the USEPA MCL for arsenic is $50 \mu \mathrm{g} / \mathrm{L}$ (see table 11). To protect aquatic life, the USEPA (1986) recommends a chronic freshwater criterion (a 4-day average concentration occurring once in a 3-year period on the average) of $190 \mu \mathrm{g} / \mathrm{L}$ of $\mathrm{As}^{3+}$. Arsenic concentrations in CBP water samples were small with a median concentration of $3 \mu \mathrm{g} / \mathrm{L}$. Abovt 10 percent of the samples had concentrations less than the reporting limit, and no sample concentration exceeded USEPA standards or criteria. The maximum arsenic concentration of $12 \mu \mathrm{g} / \mathrm{L}$ was in the March sample from Lind Coulee Wasteway. 
Chromium is found in air, soil, and living organisms, but is usually absent from natural water or present only in trace amounts (Hem, 1989). Elevated concentrations of chromium are harmful to human beings and toxic to fish and freshwater invertebrates. The USEPA (1992a) designated a drinking water $\mathrm{MCL}$ of $100 \mu \mathrm{g} / \mathrm{L}$ for chromium and a freshwater chronic criterion of $210 \mu \mathrm{g} / \mathrm{L}$ for the protection of aquatic life (U.S. Environmental Protection Agency, 1986) (see table 11). Chromium was detected in only three samples collected during the study: the November and March samples from Crab Creek near Beverly and the March sample from Wahluke Branch 10A Wasteway. The concentrations in these three samples did not exceed $10 \mu \mathrm{g} / \mathrm{L}$.

Copper exists in nature as the metal and as a component of various minerals. The oxides and sulfates of copper are used in pesticides and incorporated into paints and wood preservatives to inhibit biological growth. Copper is an essential micronutrient for plants and animals, but is toxic to aquatic life if the water has low alkalinity or hardness. The chronic criterion to protect freshwater life is $12 \mu \mathrm{g} / \mathrm{L}$ in water that has a hardness of $100 \mathrm{mg} / \mathrm{L}$. Eightysix percent of the samples collected during this study were equal to or less than the analytical reporting limit of $1 \mu \mathrm{g} / \mathrm{L}$. The median copper concentration for the study was $0.7 \mu \mathrm{g} / \mathrm{L}$. In comparison, in a study of more than 1,500 surface waters, the USEPA (1976) reported an average copper concentration of $15 \mu \mathrm{g} / \mathrm{L}$.

Lead and mercury concentrations in natural water are typically small because they tend to complex with inorganic and organic substances. In addition, mercury is volatile and escapes to the atmosphere as vapor (Hem, 1989). Both metals can accumulate in animal and human tissues and are highly toxic. The concentrations of lead and mercury in the water samples were mostly less than the analytical reporting limits of $1 \mu \mathrm{g} / \mathrm{L}$ (table 25). Two concentrations--one each of lead and mercury--were particularly large, but they could be incorrect due to analytical or sampling errors. The November sample from Crab Creek near Beverly had a lead concentration of $29 \mu \mathrm{g} / \mathrm{L}$, which exceeds the USEPA (1986) criterion of $3.2 \mu \mathrm{g} / \mathrm{L}$ for the protection of freshwater life. The March sample from EL68D Wasteway had a mercury concentration of $3 \mu \mathrm{g} / \mathrm{L}$, which exceeds USEPA's (1992a) MCL of $2 \mu \mathrm{g} / \mathrm{L}$ for drinking water and acute freshwater criterion of $2.4 \mu \mathrm{g} / \mathrm{L}$ for the protection of aquatic life.

Selenium is found in some sandstones and limestones and is associated with uranium ore deposits (National Academy of Sciences, 1976). NIWQP studies of several irrigation project areas in the western States have shown that seleniferous marine shales of Cretaceous age are important sources of selenium t? soils derived from these formations (Feltz and others: 1990; Sylvester and others, 1988). Selenium is also a component of some pesticides. Because of selenium toxicity to humans, the USEPA (1992a) has designated an MCL of $50 \mu \mathrm{g} / \mathrm{L}$ in drinking water. To protect aquatic life, the USEPA (1986) recommended a chronic freshwater criterion of $5 \mu \mathrm{g} / \mathrm{L}$ and an acute freshwater criterion of $20 \mu \mathrm{g} / \mathrm{L}$. Lemly and Smith (1987) indicated that selenium concentrations greater than $2-5 \mu \mathrm{g} / \mathrm{L}$ in water can be bioconcentrated in the food chain and cause toxicity and reproductive fail rre in fish. Only three samples collected during this study had selenium concentrations greater than the analyticel reporting limit of $1 \mu \mathrm{g} / \mathrm{L}$. No selenium concentration exceeded either of the fresh-water criteria; however, the maximum concentration of $4 \mu \mathrm{g} / \mathrm{L}$ determined in the March sam jle from EL68D Wasteway is within the range of concentrations $(2-5 \mu \mathrm{g} / \mathrm{L})$ that can adversely affect fish (Lemly ant Smith, 1987). Concentrations in the March samples fr?m PE16.4 Wasteway and Esquatzel Coulee Wastervay were $2 \mu \mathrm{g} / \mathrm{L}$.

Zinc is commonly associated with the sulfides of such metals as lead, copper, cadmium, and iron. Zinc is an important micronutrient in human metabolism. Because zinc can be toxic to aquatic life, the USEPA (1986) recommended a freshwater chronic criterion cf $110 \mu \mathrm{g} / \mathrm{L}$ in water with hardness of $100 \mathrm{mg} / \mathrm{L}$. Becruse zinc can also be toxic to a variety of plants, Environment Canada (1979) recommended a limit of $2,000 \mu \mathrm{g} / \mathrm{L}$ zin: in irrigation water. Although numerous sources of zinc exist in the Columbia River watershed, the median concentration of zinc in CBP water samples was $3.7 \mu \mathrm{g} / \mathrm{L}$, and ranged from less than 3 to $13 \mu \mathrm{g} / \mathrm{L}$.

\section{$\underline{\text { Pesticides }}$}

Pesticides are a large group of synthetic organic compounds with many different chemical and physical properties. These properties, especially aqueous solubilities, determine the extent to which pestisides and other organic compounds are found in water, bottom sediment, and tissues of aquatic organisms (Smith and others, 1988). Pesticides enter surface-water bodies in several ways, but eroded soil containing sorbed pesticide residues is considered the primary source of contaminants to surface-water systems (Smith and others, 1988). Because of their inherent toxic design, pesticides can cause en vironmental harm despite small concentrations. 
In this study, insecticides and herbicides were the two major classes of pesticides of interest. In addition to their unique designs to act on biota, insecticides and herbicides typically behave differently in the water environment. Non-ionic compounds, such as organochlorine insecticides and PCBs, are nearly insoluble in water and are usually found to be less than analytical reporting limits. Instead, they tend to sorb to soils and bottom sediment by partitioning into organic matter where their concentrations can become relatively large and persist for several years (Smith and others, 1988). These types of organic compounds can concentrate in biological tissues and have the potential to adversely affect the organism itself or its predators. In contrast to chlorinated insecticides, the organophosphorus insecticides, such as diazinon and malathion, are relatively soluble in water and do not tend to partition into organic matter (Smith and others, 1988). Ionic compounds, such as the acid herbicides, typically are soluble in water. The herbicides do not tend to bioconcentrate and are generally non-persistent in the environment. Many herbicides are rapidly degraded by microbial action or by photolytic or hydrolytic reactions (Smith and others, 1988).

Most of the different types of insecticides, herbicides, and other organic compounds analyzed for in this study were not detected in 51 water samples (table 26). Of those that were detected, there were 18 positive detections of insecticides such as chlorpyrifos, DDT, DDE (a metabolic product of DDT), dieldrin, disulfoton, lindane, malathion, methyl parathion, and methoxychlor; however, only 7 of the 18 detections were greater than the analytical reporting limit. There were 31 positive detections of herbicides, mostly of 2,4-D (table 12). Most pesticide detections were observed in samples collected in July during the irrigation season. Insecticides were detected only in the July samples from six sites; Potholes Reservoir in east arm, Lower Crab Creek at McManamon Road, Lower Goose Lake, EL68D Wasteway, PE16.4 Wasteway, and Esquatzel Coulee Wasteway. The single detected concentration of DDT $(0.002 \mu \mathrm{g} / \mathrm{L})$ and of methoxychlor $(0.07 \mu \mathrm{g} / \mathrm{L})$, and the maximum observed concentration of dieldrin $(0.014 \mu \mathrm{g} / \mathrm{L})$ exceeded USEPA (1986) chronic criteria for the protection of aquatic life (see table 11). Except for methoxychlor, these insecticide values were from the sample taken at EL68D Wasteway; methoxychlor was detected in the sample from Lower Crab Creek at McManamon Road. In general, pesticides were present in more variety and in more samples of water from EL68D Wasteway than from any of the other sites, however the concentrations were small.
The herbicide 2,4-D was detected in more samples than any other pesticide during the study; 26 samples, mostly collected in July during the irrigation season, had 2,4-D present in concentrations ranging from 0.01 to $1.0 \mu \mathrm{g} / \mathrm{L}$. The maximum value of 2,4-D observed during this study was in the November (po-tirrigation) sample collected from PE16.4 Wasteway; 2,4-D was not detected in any of the March samples (pre-irrigation). Two other herbicides detected in water samples were dicamba and picloram. Dicamba ranged in concentrations from 0.01 to $1.0 \mu \mathrm{g} / \mathrm{L}$ in samples collected from Moses Lake in Parker Horn arm, Wahluke Branch 10A Wasteway, and Saddle Mountain Wasteway. Davis (1993) also found dicamba in Crab Creek near Beverly in a conce tration of $0.01 \mu \mathrm{g} / \mathrm{L}$. Picloram was detected at a concentration of $0.02 \mu \mathrm{g} / \mathrm{L}$ in one sample from Winchester Wastervay.

\section{Concentrations of Constituents in Bottom Sediment}

Bottom sediment in surface-water systems is composed of fine-, medium-, and coarse-grained minerals and organic particles in varying proportions. The bottom sediment is important because it provides habitat to aquatic organisms, many of which are an important part of the food-chain base. Bottom sediment also serves as a sink, collecting a wide range of chemical and debris that enter into streams and lakes. Some chemicals and metals can accumulate in larger amounts in bot'om sediment than are found in the overlying water body. In the bottom sediment, various compounds can be chemically and biologically transformed into more or less toxic forms, or they can be taken up by benthic organisns and eventually contaminate fish, wildlife, and humans through the food chain. Direct transfer of chemicals from bottom sediment to benthic organisms is considered an important exposure pathway (Burton, 1992).

Samples of bottom sediment c.llected from 21 sampling locations during irrigation season were analyzed for trace elements and organochlorine insecticides. The results of trace-element analyses are listed in table 27 and the results of organochlorine-insecticide analyses are listed in table 28 at the end of the reprt. As has been done in other NIWQP studies, summarier of trace-element concentrations in the samples from this study are compared with geochemical baseline concentrations established for soils in the western United States (Shacklette and Boerngen, 1984) (see table 13). 
Table 12.--Summary of insecticides, herbicides, and other organic compounds in water samples from the Columbia Basin Project, November 1991, March 1992, and July 1992

[Concentrations are in micrograms per liter; --, not applicable]

\begin{tabular}{|c|c|c|c|}
\hline Compound (trade name) & $\begin{array}{l}\text { Number } \\
\text { of } \\
\text { detections }\end{array}$ & $\begin{array}{l}\text { Maximum } \\
\text { concentration }\end{array}$ & $\begin{array}{l}\text { Site where maximum } \\
\text { concentration was detected }\end{array}$ \\
\hline Aldrin & 0 & -- & -- \\
\hline Chlordane & 0 & -- & -- \\
\hline Chlorpyrifos (Lorsban) & 3 & 0.03 & EL68D Waste.way \\
\hline DDD & 0 & -- & - \\
\hline DDE & 1 & $0.003^{\mathrm{a}}$ & EL68D Wasteway \\
\hline DDT & 1 & $0.002^{\mathrm{a}}$ & EL68D Wasteway \\
\hline Diazinon & 0 & -- & -- \\
\hline Dieldrin & 6 & $0.014^{\mathrm{a}}$ & EL68D Wasteway \\
\hline Disulfoton (Disyston) & 1 & 0.01 & EL68D Wasteway \\
\hline Endosulfan (Thiodan) & 0 & - & - \\
\hline Endrin & 0 & -- & -- \\
\hline Ethion & 0 & -- & - \\
\hline Ethylan (Perthane) & 0 & -- & -- \\
\hline Fonofos (Dyfonate) & 0 & -- & - \\
\hline Heptachlor & 0 & -- & -- \\
\hline Heptachlor epoxide & 0 & -- & -- \\
\hline Lindane & 1 & 0.001 & EL68D Wasteway \\
\hline Malathion & 1 & 0.03 & $\begin{array}{l}\text { Lower Crab Creek, } \\
\text { McManamon Road }\end{array}$ \\
\hline Methoxychlor & 1 & $0.07^{\mathrm{a}}$ & $\begin{array}{l}\text { Lower Crab Creek, } \\
\text { McManamo? Road }\end{array}$ \\
\hline Methyl parathion & 3 & 0.01 & $\begin{array}{l}\text { Potholes Reservoir, east arm; } \\
\text { Lower Goose Lake; } \\
\text { EL68D Wasteway }\end{array}$ \\
\hline Mirex & 0 & -. & -- \\
\hline Parathion & 0 & -- & - \\
\hline Phorate (Thimet, Rampart) & 0 & -- & -- \\
\hline Toxaphene & 0 & - &.- \\
\hline Trithion & 0 & $\cdots$ & -- \\
\hline $2,4-\mathrm{D}$ & 26 & 1.0 & PE16.4 Wasteway \\
\hline $2,4,5-\mathrm{T}$ & 0 & -. & -- \\
\hline $2,4-D P$ & 0 & -- & -- \\
\hline Dicamba (Banvel) & 4 & 1.0 & Saddle Mountain Wasteway \\
\hline Picloram (Tordon) & 1 & 0.02 & Winchester Wasteway \\
\hline $\begin{array}{l}\text { S,S,S-Tributylphosphoro- } \\
\text { trithioate (DEF) }\end{array}$ & 0 & - & $x_{1}$ \\
\hline 2,3,4-TP (Silvex) & 0 & -- & -- \\
\hline PCB & 0 & -- & -- \\
\hline PCN & 0 & -- & - \\
\hline
\end{tabular}

${ }^{\text {a }}$ Concentration exceeds U.S. Environmental Protection Agency (1986) 24-hour chronic criterion. 
Table 13.--Summary of trace-element concentrations in bottom-sediment samples from the Columbia Basin Project and geochemical baseline concentrations for soils from the western United States

[Total concentrations, in micrograms per gram unless otherwise indicated; $\%$-Wt, percent by weight; $>$, greater than; $<$, less than; --, no data]

\begin{tabular}{|c|c|c|c|c|}
\hline \multirow[b]{2}{*}{ Element } & \multicolumn{2}{|c|}{ Bottom sediment } & \multicolumn{2}{|c|}{ Western soils $^{\mathrm{a}}$} \\
\hline & Median & Range & $\begin{array}{l}\text { Geometric } \\
\text { mean }\end{array}$ & $\begin{array}{l}\text { Baseline } \\
\text { range? } b\end{array}$ \\
\hline Aluminum $(\%-W t)$ & 6.6 & $2.3-7.4$ & 5.8 & $0.5->10$ \\
\hline Arsenic & 4.6 & $3.0-11.0$ & 5.5 & $1.2-22$ \\
\hline Barium & 570 & $190-760$ & 580 & $200-1,700$ \\
\hline Beryllium & 2 & $<1-2$ & 0.68 & $0.13-3.6$ \\
\hline Boron & 0.4 & $<0.2-1.0$ & 23 & $5.8-91$ \\
\hline Cadmium & $<2$ & $<2$ & -- & - \\
\hline Calcium $(\%-W t)$ & 3.7 & $2.1-15$ & 1.8 & $0.19-17$ \\
\hline Carbon (\%-Wt) & 2.0 & $0.13-16$ & -- & - \\
\hline Chromium & 34 & $11-48$ & 41 & $8.5-200$ \\
\hline Copper & 20 & $12-43$ & 21 & $4.9-90$ \\
\hline Iron $(\%-W t)$ & 3.9 & $0.95-5.0$ & 2.1 & $0.55-8.0$ \\
\hline Lead & 11 & $5-18$ & 17 & $5.2-55$ \\
\hline Magnesium (\%-Wt) & 1.3 & $0.50-2.0$ & 0.74 & $0.15-3.6$ \\
\hline Manganese & 660 & $150-2,800$ & 380 & $97-1,500$ \\
\hline Mercury & 0.017 & $<0.02-0.03$ & 0.046 & $0.0085-0.25$ \\
\hline Molybdenum & $<2$ & $<2-3$ & 0.85 & $0.18 \cdot 4.0$ \\
\hline Nickel & 16 & $6-23$ & 15 & $3.4-66$ \\
\hline Phosphorus (\%-Wt) & 0.10 & $0.07-0.17$ & 0.032 & $0.0055-0.17$ \\
\hline Potassium (\%-Wt) & 1.5 & $0.45-2.3$ & $1.8^{\mathrm{c}}$ & $0.38-3.2$ \\
\hline Selenium & 0.3 & $<0.1-4.1$ & 0.23 & $0.039-1.4$ \\
\hline Silver & $<2$ & $<2$ & - & -. \\
\hline Sodium $(\%-W t)$ & 1.7 & $0.80-2.1$ & 0.97 & $0.26-3.7$ \\
\hline Strontium & 380 & $180-590$ & 200 & $43-930$ \\
\hline Thorium & 6.9 & $<3-10$ & 9.1 & $4.1-20$ \\
\hline Titanium $(\%-W t)$ & 0.50 & $0.13-0.67$ & 0.22 & $0.069-0.70$ \\
\hline Uranium & 2.4 & $1.8-8.0$ & 2.5 & $1.2-5.3$ \\
\hline Vanadium & 120 & $52-180$ & 70 & $18-270$ \\
\hline Yttrium & 17 & $5-21$ & 22 & $8-60$ \\
\hline Ytterbium & 2.0 & $<1-3$ & 2.6 & $0.98-6.9$ \\
\hline Zinc & 66 & $32-96$ & 55 & $17-180$ \\
\hline
\end{tabular}

\footnotetext{
${ }^{a}$ Modified from Shacklette and Boerngen (1984).

${ }^{b}$ Range in which 95 percent of sample concentrations are expected to occur.

${ }^{c}$ Arithmetic mean.
} 
Many of the trace elements of interest in the bottomsediment samples were present only in small concentrations. Concentrations of beryllium, mercury, and molybdenum were mostly less than reporting limits; cadmium, silver, and gold were not detected in any of the samples (see table 27). The median concentrations of most trace elements were within the baseline range of concentrations for western soils. In bottom sediment from the CBP (based on median concentrations), the common elements were calcium, iron, magnesium, manganese, phosphorus, sodium, strontium, titanium, and vanadium (table 13).

Of all the trace-element concentrations measured, only the maximum observed concentrations of selenium, uranium, and manganese exceeded the upper value of the baseline range of concentrations. The maximum observed selenium concentration of $4.1 \mu \mathrm{g} / \mathrm{g}$ (micrograms per gram) was essentially the same as the value $(4.0 \mu \mathrm{g} / \mathrm{g})$ identified as a level of concern for the health of wildlife (Joe Skorupa, U.S. Fish and Wildlife Service, oral commun., April 1993). Both the maximum observed selenium and uranium concentrations $(8.0 \mu \mathrm{g} / \mathrm{g})$ were found in the sample taken from Rocky Ford Creek; the maximum concentration of manganese $(2,800 \mu \mathrm{g} / \mathrm{g})$ was in the sample collected from Lower Crab Creek at McManamon Road. Although the maximum concentrations of selenium and uranium in bottom sediment were large compared with the baseline concentrations, they were exceptionally small compared with concentrations observed in other irrigation-drainage study areas. For example, in the Middle Green River Basin (Utah), selenium concentration in the bottom sediment (less than 63 micrometer fraction) was as much as $85 \mu \mathrm{g} / \mathrm{g}$ and uranium was as much as $18.6 \mu \mathrm{g} / \mathrm{g}$ (Stephens and others, 1988).

A variety of organochlorine pesticides were found in bottom-sediment samples collected throughout the CBP. Of 17 organic compounds in the analytical suite, $7 \mathrm{com}$ pounds--chlordane, ethylan, heptachlor, lindane, toxaphene, PCBs, and PCNs--were not detected in any of the bottom-sediment samples (see table 28). Samples from all but two sites had at least one detection of some insecticide. Seven insecticides were detected in the sample from Lower Goose Lake: aldrin, DDT, DDD, DDE, dieldrin, endosulfan, and methoxychlor. A greater variety of insecticides was detected in the samples from Lower Goose Lake, Frenchman Hills Wasteway, Sand Hollow Creek, and EL68D Wasteway than from the other sites.

In a report on the intensively irrigated Yakima River Basin, Rinella and others (1992) described the direct relation between organochlorine-insecticide concentrations and the suspended sediment from eroded agricultural soils. A similar relation probably exists for several of the CBP wasteways, particularly for EL68D and Lind Coulee, which carry large amounts of suspended sediment. These two wasteways flow through areas where gravity irrigation, which causes substantially more soil erosion from the fields than sprinkler irrigation, is the rost common practice.

Numerous detections of the banred organochlorine insecticides, DDT and dieldrin, and the DDT metabolites, DDD and DDE, show that these comprunds still persist in much of the CBP. Of all the organochlorine compounds determined, DDE was detected most frequently; 18 of the 21 samples had DDE concentrations as large as $7.8 \mu \mathrm{g} / \mathrm{kg}$ (micrograms per kilogram) (table 14). Of the insecticides, dieldrin and DDT were detected in 8 of the 21 samples in concentrations as large as 3.6 and $4.0 \mu \mathrm{g} / \mathrm{kg}$, respectively. Compared with concentrations in sedi nent samples from the Yakima River Basin, however, the concentrations of dieldrin and DDT in bottom sediment from the CBP are quite small: maximum concentrations of $90 \mu \mathrm{g} / \mathrm{kg}$ (DDT) and $14.9 \mu \mathrm{g} / \mathrm{kg}$ (dieldrin) were measur $\%$ in sediment from Yakima River Basin wasteways (Rinella and others, 1992). Sampling sites with the largest observed concentrations of organochlorine compounds were EL68D Wasteway with $2.7 \mu \mathrm{g} / \mathrm{kg}$ of DDD and $7.8 \mu \mathrm{g} / \mathrm{kg}$ of DDE; and Upper Crab Creek with $3.6 \mu \mathrm{g} / \mathrm{kg}$ of dieldrin. The sample from Lind Coulee Wasteway contained the largest concentration of DDT-- $4.0 \mu \mathrm{g} / \mathrm{kg}$. The magnitude of this concentration could have been due in $\mathrm{F}$ art to the June 1992 rupture of East Low Canal that washed agricultural soils, which might have contained quantities of unmetabolized DDT, into Lind Coulee Wasteway.

Methoxychlor, another organoch'orine insecticide, came into extensive use in 1969 as a replacement for DDT (Smith and others, 1988). Factors that contribute to the movement of methoxychlor in the environment include its volatility and its tendency to drift. When methoxychlor is sprayed, as much as 50 percent can drift out of the target area (Gardner and Bailey, 1975). Methoxychlor was found in samples from nine of the sites. The sample from Lind Coulee Wasteway contained the largest value of methoxychlor $(2.4 \mu \mathrm{g} / \mathrm{kg})$; the sample from Rocky Ford Creek contained the second-largest concentration (1.4 mg/kg). Other published NIWQP reconnaissance studies have reported only one detection of methoxychlor in bottom sediment at a concentration of $1 \mu \mathrm{g} / \mathrm{kg}$, with no detections in water.

Because of the fishery decline in Moses Lake, the incidence of pesticide detections in the lake is of interest. Methoxychlor was present at a concen ${ }^{+}$ration of $0.4 \mu \mathrm{g} / \mathrm{kg}$ in the bottom-sediment sample from $\mathrm{P}_{i}$-ker Horn arm of Moses Lake. Other organochlorine compounds in the 
Table 14.--Summary of insecticides and other organic compounds in bottom-sediment samples from the Columbia Basin Project, July 1992

[Concentrations are in micrograms per kilogram; --, not applicable]

\begin{tabular}{|c|c|c|c|c|c|c|}
\hline \multirow[b]{2}{*}{ Compound (trade name) } & \multirow{2}{*}{$\begin{array}{l}\text { Number of } \\
\text { sampling } \\
\text { sites where } \\
\text { compounds } \\
\text { were detected }\end{array}$} & \multirow[b]{2}{*}{$\begin{array}{l}\text { Maximum } \\
\text { concentration }\end{array}$} & \multicolumn{4}{|c|}{ Historical Medians ${ }^{1}$ (1974-7ミ) } \\
\hline & & & $\begin{array}{l}\text { Frenchman } \\
\text { Hills } \\
\text { Wasteway }\end{array}$ & $\begin{array}{l}\text { Lind } \\
\text { Coulee } \\
\text { Wasteway }\end{array}$ & $\begin{array}{l}\text { Crab Creek } \\
\text { near } \\
\text { Beverly }\end{array}$ & $\begin{array}{l}\text { Crab } \\
\text { Creek } \\
\text { Lateral }\end{array}$ \\
\hline Aldrin & 5 & 0.7 & -- & -- & -- & - \\
\hline Chlordane & 0 & -- & -. & -- & -- & .- \\
\hline DDD & 12 & 2.7 & -. & 3 & -- & 6 \\
\hline DDE & 18 & 7.8 & -. & 7 & -- & 11 \\
\hline DDT & 8 & 4.0 & 1 & 10 & - & 11 \\
\hline Dieldrin & 8 & 3.6 & 6 & 8 & 3 & 7 \\
\hline Endosulfan (Thiodan) & 4 & 0.3 & .. & -- & -- & -- \\
\hline Endrin & 1 & 0.1 & -. & -- & .. & -- \\
\hline Ethylan (Perthane) & 0 & -- & .. & .- & -- & -. \\
\hline Heptachlor & 0 & -- & -. & -- & -. & -- \\
\hline Heptachlor epoxide & 4 & 1.0 & -. & -- & -. & -. \\
\hline Lindane & 0 & -- & -. & -- & -- & - \\
\hline Methoxychlor & 9 & 2.4 & -- & -- & -- & .- \\
\hline Mirex & 1 & 0.2 & - & -- & -- & -- \\
\hline Toxaphene & 0 & - & - & -- & -- & -- \\
\hline PCBs & 0 & -. & - & -. & -- & -- \\
\hline PCNs & 0 & -- & - & -- & - & -. \\
\hline
\end{tabular}

${ }^{1}$ From K. E. Greene, U.S. Geological Survey, written commun., April 1993.

Parker Horn arm sample included DDT and its metabolites and heptachlor epoxide (the oxidation product of heptachlor). DDD and DDE were found also in the other two Moses Lake samples: one collected in the Rocky Ford arm and one collected in the south end.

\section{Concentrations of Constituents in Biota}

Because some trace elements and pesticides accumulate in biota, the analysis of biological tissue for these constituents can provide two important types of information.

(1) Contaminant integration--Contaminants distributed unevenly in space and time within the environment are integrated in biological tissue. Biota are exposed to the contaminant throughout the habitat over time and can provide a measure of central tendency of the concentration in the environment. Contaminants introduced into a stream can scmetimes be detected in biota for a period of time after the contaminant has moved downstream and is no longer detectable in a water sample at the point of discharge.

(2) Potential toxicity--Concentrations of some contaminants in tissue can be compared with other studies that have documented adverse effects as an initial step in evaluating potential contaminant effects on biota in the study area.

A trace element or pesticide de ermined in biological tissue is referred to as elevated if it 1 as accumulated to concentrations greater than (1) those measured at reference sites; (2) concentrations considored to be elevated in monitoring programs or studies; or (3) concentrations governed by established criteria. The term "elevated" does not imply that the constituent at such a concentration will adversely affect the organism or the environment. 
A trace element or pesticide is referred to as causing adverse effects if the concentration of the constituent in the tissue or a food is similar to or higher than concentrations shown in exposure studies to result in physiological or behavioral aberrations. Effects can occur at the individual, population, or community level of the ecosystem and can be as obvious as mortality, or as subtle as a reduction in alert behavior that results in an increased likelihood of predation. Tissue concentrations can be compared with those measured in laboratory exposure studies that documented contaminant effects. The difficulty of extrapolating experimental laboratory results to the complex, dynamic ecosystem limits the adequacy with which laboratory and field data can be compared.

\section{Trace Elements}

Unlike synthetic organic contaminants, trace elements occur naturally in aquatic systems and biological tissue. Many trace elements are essential micronutrients, whereas others have no known biological function. Organisms are able to regulate some trace elements, but the biological regulatory mechanisms can be overwhelmed by large concentrations. Toxicity to biota from different trace elements ranges from highly toxic to virtually nontoxic, and varies with environmental characteristics of the water or sediment such as temperature and $\mathrm{pH}$. Effects to biota caused by the presence of certain trace elements can be difficult to assess because of antagonistic or synergistic effects caused by exposure to more than one contaminant.

Few regulatory standards or criteria are available for trace element tissue concentrations in biota. Although the effects of some trace elements such as selenium and mercury have been documented, most of the less-toxic elements have received little attention. For this study, concentrations of trace elements in whole fish from the CBP were compared with the NCBP 85th percentile value (Schmitt and Brumbaugh, 1990) and were designated as elevated if trace-element concentrations exceeded the NCBP value. Thus, an elevated concentration is one that exceeded the concentrations found in 85 percent of several fish species collected from 109 stations on major rivers throughout the United States. Trace-element concentrations in other biota samples from the CBP were compared with results from a variety of studies. Results for adjacent sites were also compared to determine if a pattern of concentrations existed that might help explain the source of the element. Only those elements that were found in CBP biota in elevated concentrations or those elements that are typically a problem in irrigation drainage are discussed in this section. The results of the trace-element analyses for fish, birds, pondweed, and snails collected are provided in tables 30 (in wet weight) and 31 (in d-y weight) at the end of the report. The results of the trace-element analyses for bird eggs are shown in table 32 (both wet and dry weight).

\section{Arsenic}

Arsenic concentrations are not elevated in CBP biota with the exception of arsenic concent-ations in coots. In general, arsenic concentrations in CBP biological tissues were less than concentrations reporter in other studies and reviews that were considered to be elevated or that caused effects in dietary exposure studies (ta'ble 15). Arsenic concentrations ranging from nondetection to $9.25 \mu \mathrm{g} / \mathrm{g}$ dry weight in the livers of juvenile coots from all the coot collection sites except Billy Clapp Lake were similar to concentrations ( 0.5 to $9.9 \mu \mathrm{g} / \mathrm{g}$ dry weight) in the livers of 10-week old mallards adversely affected by the consumption of arsenic-supplemented meal given during laboratory studies. These mallards exhibited reduced growth, increased resting time, and alteration of a variety of enzyme and blood chemistry levels (Camardese and others, 1990). In pondweed, arsenic concentrations were within the range of concentrations $(1.43$ to $13 \mu \mathrm{g} / \mathrm{g}$ dry weight) found in aquatic plants collested from reference sites (Eisler, 1988). In snails, the consentrations were less than those found by Spehar and others (1980) to cause mortality in other genera of freshwater snails and were within the range of concentrations (from less than 0.5 to $20 \mu \mathrm{g} / \mathrm{g}$ dry weight) found in various invertebrates collected from uncontaminated fresh waters (Moore and Ramamoorthy, 1984). Two of 44 carp had an arsenic concentration of $0.28 \mu \mathrm{g} / \mathrm{g}$ wet weight, approximately the same as the NCBP 85th percentile level of $0.27 \mu \mathrm{g} / \mathrm{g}$ wet weight (Schmitt and Brumbaugh, 1990).

All samples of plant-consuming animals contained arsenic and the concentrations tended to be greater in the herbivorous species than in predatory species. Arsenic concentrations in snails, which feed on the epiphytic communities of pondweed and other aque tic plants, were greater than concentrations in the pordweed. About a third of the samples of omnivorous carp, most of the sampled juvenile coots (primarily an hert ivorous bird species), and half of the sampled coot eggs contained arsenic. None of the samples of predatory persh contained detectable amounts of arsenic, and only one collected juvenile grebe, a predatory species, and one sampled grebe egg contained any arsenic. Knapton and others (1988) reported similar results in their study in which juvenile coots contained arsenic, but eared grebes and American avocets did not contain detectable amounts. 


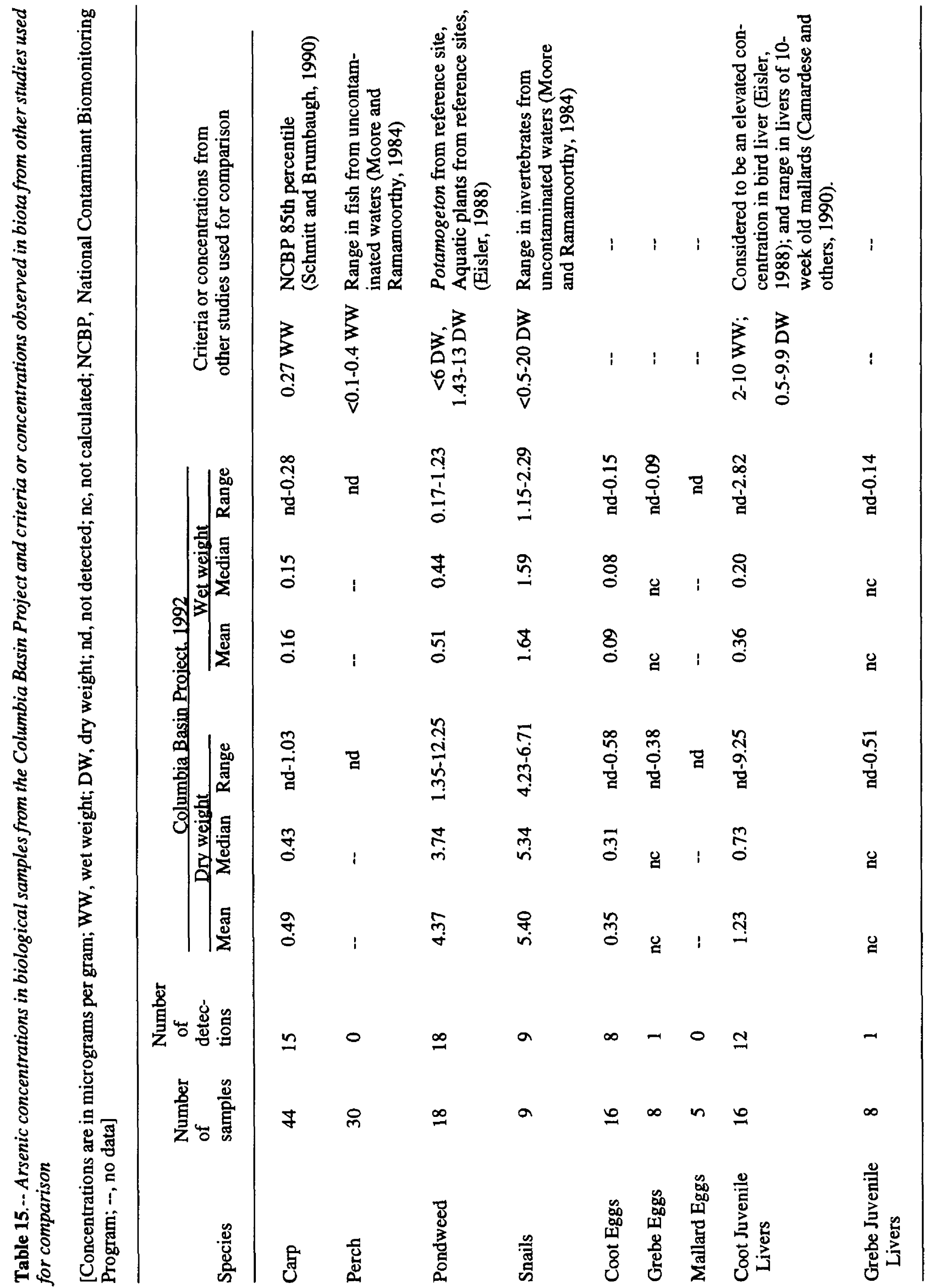


In general, boron concentrations were not elevated in CBP biota samples. However, in pondweed samples, boron had accumulated to elevated concentrations that could affect wildlife consuming this plant (table 16). Pondweed is an important dietary item for many bird species that feed on aquatic plants. Boron concentrations tended to be elevated in pondweed samples from sites receiving irrigation return flow: Potholes Reservoir in the west arm, Saddle Mountain Wasteway, Wahluke Branch Wasteway Lake, and Winchester Wasteway. In the pondweed samples from these sites, concentrations ranging from 216 to $567 \mu \mathrm{g} / \mathrm{g}$ (dry weight) were elevated compared with concentrations ( 18 to $170 \mu \mathrm{g} / \mathrm{g}$ dry weight) reported by Eisler (1990) for several species of pondweed from uncontaminated sites. Boron concentrations were small (less than $300 \mu \mathrm{g} / \mathrm{g}$ dry weight) in pondweed samples from Billy Clapp Lake, which receives little or no return flows, and in pondweed samples from Moses Lake, which receives large quantities of source water.

Boron concentrations found in pondweed from the CBP were similar to concentrations identified in several dietary exposure studies as affecting health and reproduction. In one study, mallard ducklings received feed supplemented with a range of concentrations of boron from time of hatching to 10 weeks old (Hoffman and others, 1990). At $400 \mu \mathrm{g} / \mathrm{g}$ wet weight (approximately $444 \mu \mathrm{g} / \mathrm{g}$ dry weight) in feed, brain chemistry was significantly altered, food consumption was reduced for the first few weeks, and behavioral changes included increased resting time and decreased standing and bathing time. Ducklings on the $100 \mu \mathrm{g} / \mathrm{g}$ diet (approximately $111 \mu \mathrm{g} / \mathrm{g}$ dry weight) responded similarly to controls. In another study where both parent and duckling mallard diets were supplemented with boron, adults were fed the 30 and $300 \mu \mathrm{g} / \mathrm{g}$ diets (approximately 33 and $333 \mu \mathrm{g} / \mathrm{g}$ dry weight), which caused a decrease in their duckling's hatching weights, and the $300 \mu \mathrm{g} / \mathrm{g}$ diet fed to ducklings caused a slower weight gain than normal within the 21 days after hatching (Smith and Anders, 1989).

Boron concentrations of as much as $1.56 \mu \mathrm{g} / \mathrm{g}$ dry weight in CBP coot livers were less than in duckling livers ( 1 to $36 \mu \mathrm{g} / \mathrm{g}$ dry weight) in the two dietary exposure studies described in the preceding paragraph. Boron concentrations in coot livers and pondweed were somewhat related; of the four sites where both coots and pondweed were collected, Saddle Mountain Wasteway had the largest concentrations in pondweed and the greatest frequency of coot liver samples with detectable concentrations of boron.
Cadmium concentrations did not appear to be accumulating in the pondweed and birds on the basis of analyses of samples collected. Cadmium con entrations in fish were larger in this study than in a 1985 study, when concentrations in a variety of fish species co'lected throughout the CBP area were less than the reportin? limit of $0.06 \mu \mathrm{g} / \mathrm{g}$ wet weight (Block, 1993). The mean cadmium concentrations of $0.15 \mu \mathrm{g} / \mathrm{g}$ wet weight for the perch and $0.08 \mu \mathrm{g} / \mathrm{g}$ wet weight for the carp sampl ss exceeded the NCBP 85th percentile concentration of $0.05 \mu \mathrm{g} / \mathrm{g}$ wet weight (Schmitt and Brumbaugh, 1990) (table 17). Carp and perch samples collected from Billy Clapp Lake had the largest and second-largest mean concentrations of cadmium, respectively. Cadmium concentrations of as much as $1.07 \mu \mathrm{g} / \mathrm{g}$ wet weight in all 30 perch and 14 of 44 carp samples exceeded the NCBP 85th percentile. Although cadmium concentrations in the fish were elevated compared with nationwide monitoring result - the concentrations were well below $5.0 \mu \mathrm{g} / \mathrm{g}$ wet weight, a value which Eisler (1985b) considered to be life-threatening to the fish.

Snails collected during the study ccntained cadmium in concentrations that ranged from less tivan 0.099 to $2.36 \mu \mathrm{g} / \mathrm{g}$ dry weight and greatly exceed $\mathrm{d}$ the reference concentration of less than $0.0005 \mu \mathrm{g} / \mathrm{g} \mathrm{d} \div$ ' weight established in an exposure study of a freshwater snail (Physa gyrina) by Wier and Walter (1976). Hovever, the mean concentration of $0.74 \mu \mathrm{g} / \mathrm{g}$ dry weight $\mathrm{fcr}$ the nine snail samples was much less than the $2.1 \mu \mathrm{g} / \mathrm{g}$ dry weight observed in freshwater molluscs from a stream affected by industry (Moore and Ramamoorthy, 1981). Cadmium probably has not adversely affected the snails, as all the concentrations were well below those (from 50 to $100 \mu \mathrm{g} / \mathrm{g}$ dry weight) found to cause mo tality to Physa integra in an exposure study by Spehar and others (1978).

\section{Chromium}

Chromium concentrations (table 18) were elevated in CBP biota compared with results from Eisler (1986), who reported that concentrations of chromium greater than $4.0 \mu \mathrm{g} / \mathrm{g}$ dry weight in biological tissues should be considered presumptive evidence of chromium contamination. In the CBP, chromium in 31 of 44 carp and 16 of 30 perch exceeded this concentration (fig. 12); 2 of the carp contained more than 7 times this concentration.

Chromium concentrations in 3 of the 18 pondweed samples exceeded $5 \mu \mathrm{g} / \mathrm{g}$ dry weight, a concentration seldom found in aquatic plants from uncontaminated fresh 


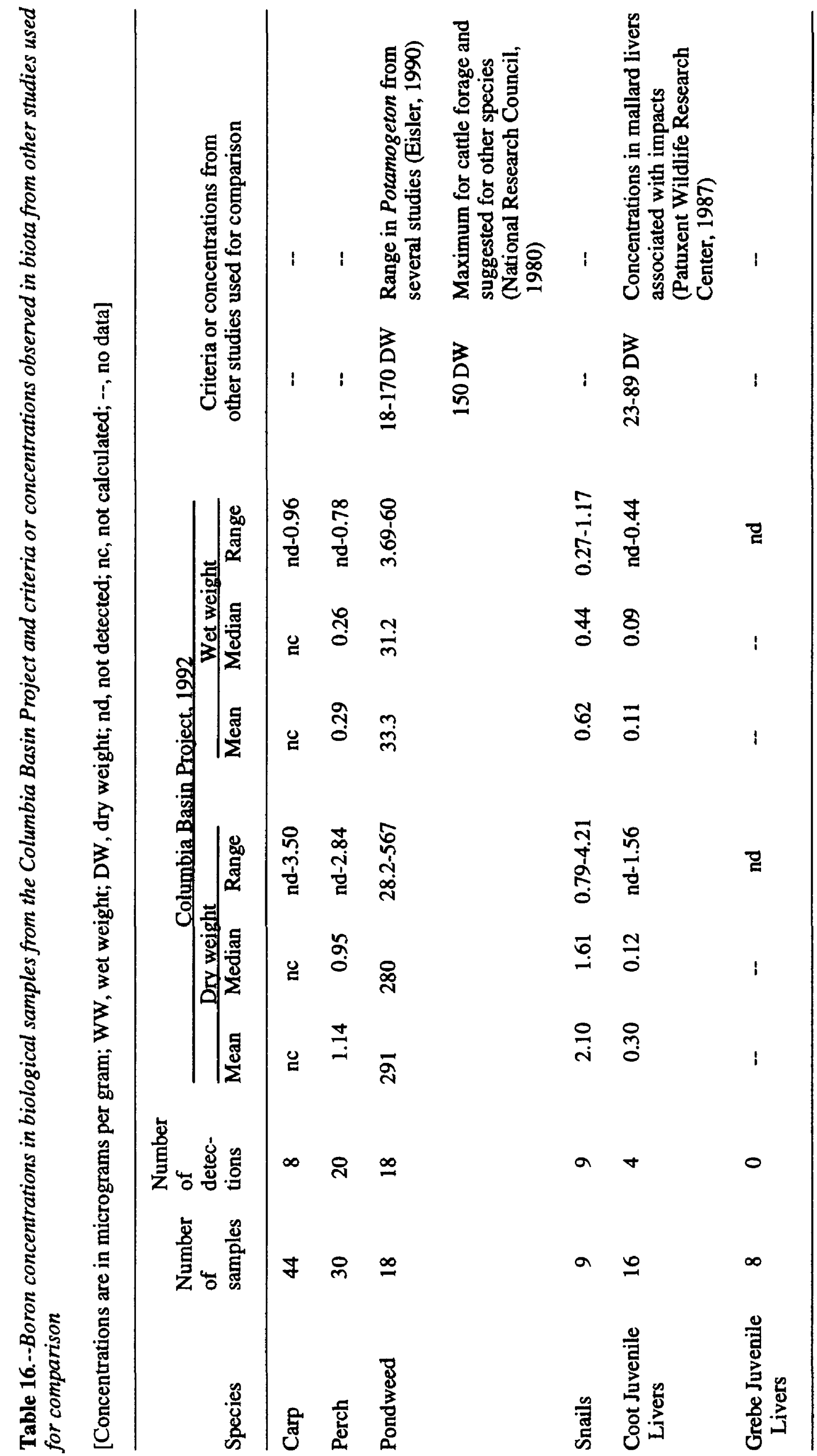




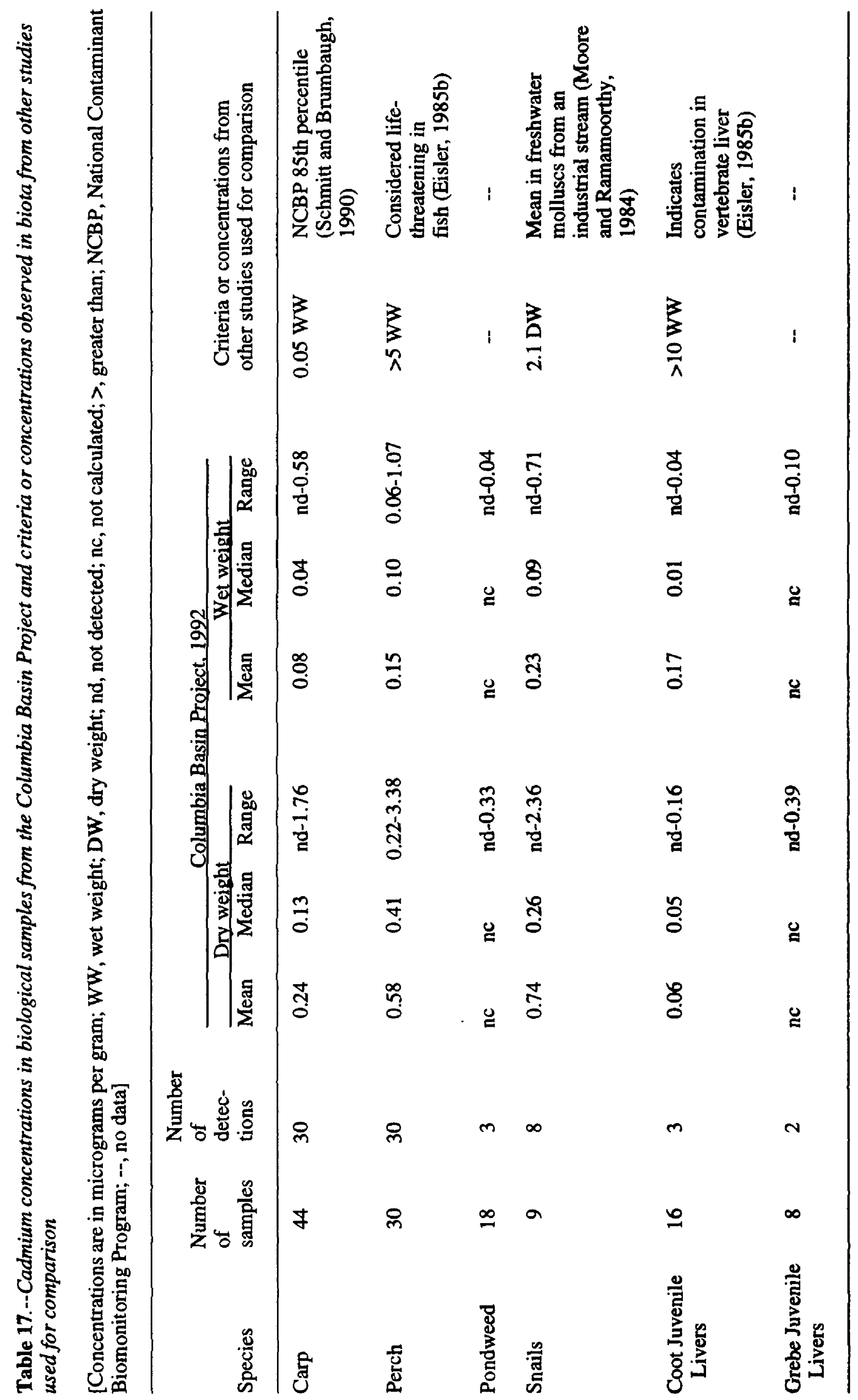




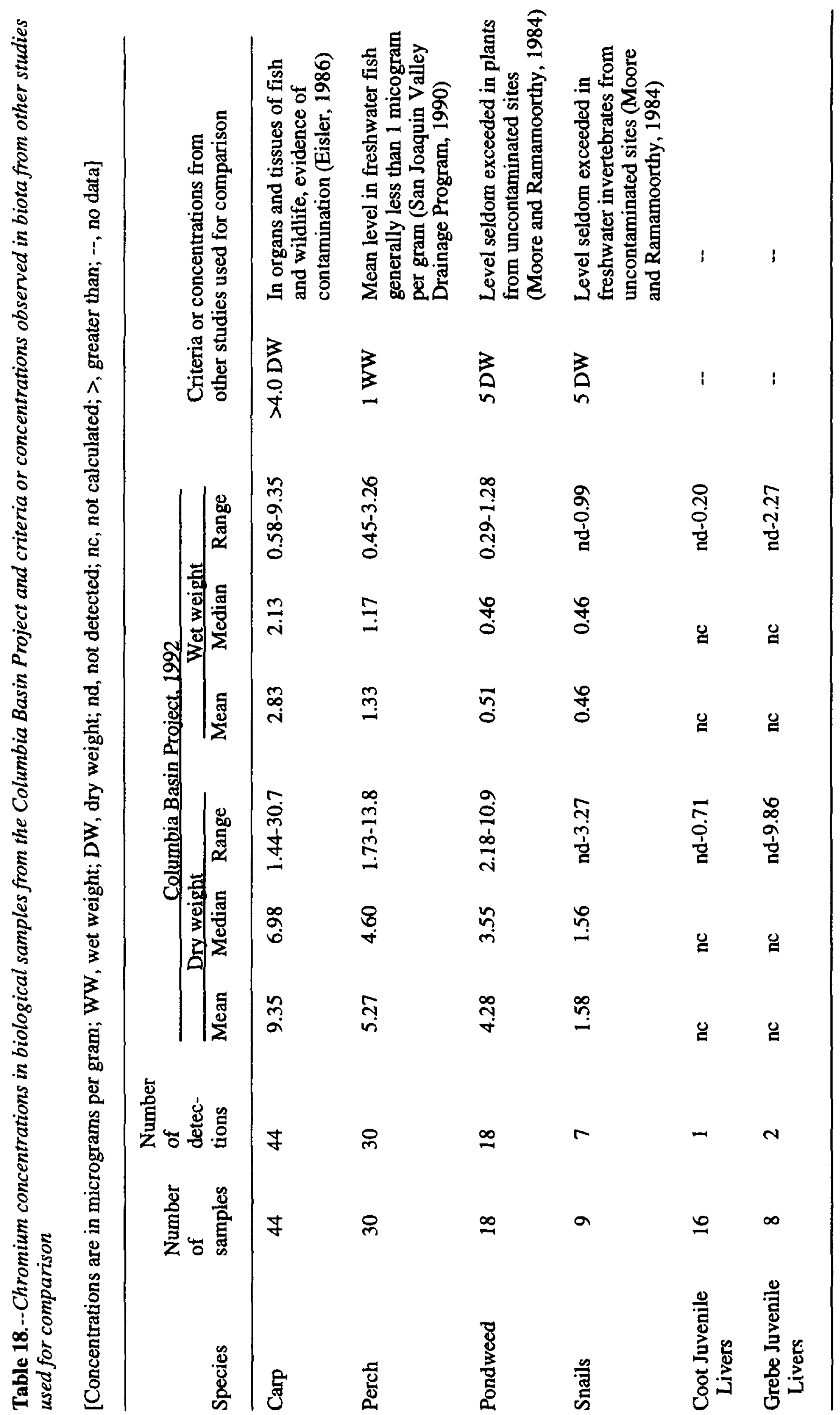




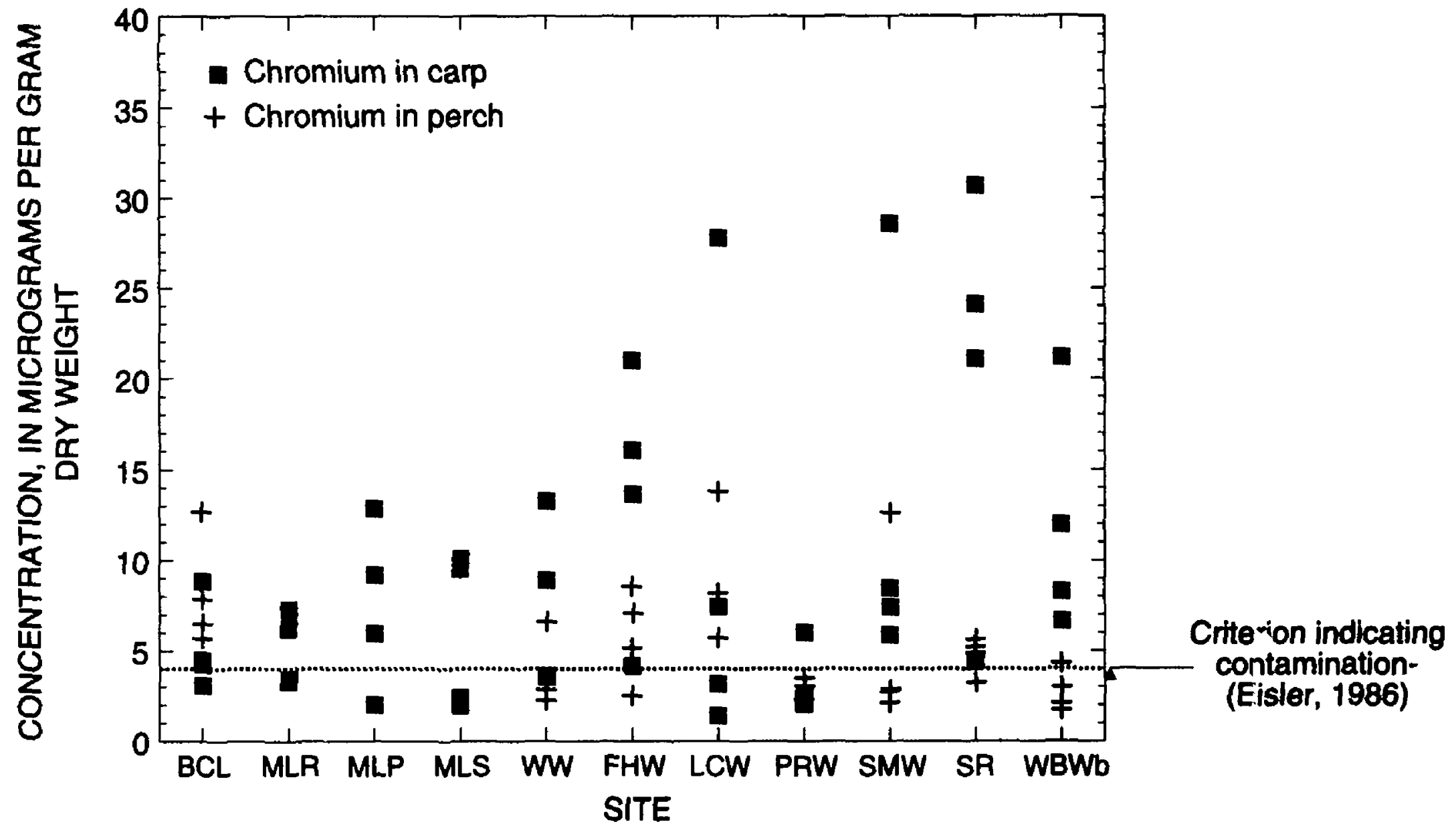

Figure 12.--Concentrations of chromium in fish samples from the Columbia Basin Project. Site abbreviation is map identifier (fig. 9); see text page 22 for explanation of map identifier. 
water (Moore and Ramamoorthy, 1984). Chromium concentrations in the CBP pondweed samples, ranging from 2.18 to $10.9 \mu \mathrm{g} / \mathrm{g}$ dry weight, were also greater than concentrations (1.04 to $1.28 \mu \mathrm{g} / \mathrm{g}$ dry weight) found in samples of two species of Potamogeton from the Kennebec River in northern New England (Friant, 1979).

Unlike concentrations in the fish and pondweed samples, chromium concentrations did not appear to be elevated in the snails from the CBP. In the snails, chromium concentrations were all less than $5 \mu \mathrm{g} / \mathrm{g}$ dry weight, which was typical of chromium concentrations in freshwater invertebrates collected from uncontaminated sites (Moore and Ramamoorthy, 1984).

The reason for the incidence of elevated chromium concentrations in the CBP biota is not known. Although chromium was present in all the bottom-sediment samples, probably from a natural but unknown geologic source, the concentrations were typical of western soils; in water, the concentrations of chromium were generally less than the reporting limit. Chromium is not a major component of the slag discharged into the Columbia River (S.E. Cox, U.S. Geological Survey, written commun., April 1993) and it is not elevated in FDR Lake.

\section{Copper}

Except for pondweed, copper concentrations were elevated in CBP biota. Concentrations in 7 of 30 perch and 42 of 44 carp exceeded the NCBP 85th percentile concentration of $1.0 \mu \mathrm{g} / \mathrm{g}$ wet weight (Schmitt and Brumbaugh, 1990) (fig. 13). Mean copper concentrations in perch $(0.85 \mu \mathrm{g} / \mathrm{g}$ wet weight $)$ and in carp $(1.9 \mu \mathrm{g} / \mathrm{g}$ wet weight) collected during this study (table 19) were larger than $0.060 \mu \mathrm{g} / \mathrm{g}$ wet weight, the mean copper concentration in several species of fish collected from the CBP in 1985 (Block, 1993).

Copper concentrations in snail samples from the CBP, which ranged from 22.8 to $87 \mu \mathrm{g} / \mathrm{g}$ dry weight, also were elevated compared with other studies. Snails (Physa sp.) collected from the Fox River (Illinois and Wisconsin) had a mean copper concentration of $22.01 \mu \mathrm{g} / \mathrm{g}$ dry weight (Anderson, 1977); herbivorous freshwater invertebrates from an industrial-area stream had a mean copper concentration of $13.7 \mu \mathrm{g} / \mathrm{g}$ dry weight; and freshwater clams (Corbicula) from an irrigation canal treated with copper sulfate had a mean concentration of $13 \mu \mathrm{g} / \mathrm{g}$ dry weight (Moore and Ramamoorthy, 1984). Three species of freshwater bivalve molluscs from the Kennebec River in northern New England contained copper ranging from 7.6 to $34.2 \mu \mathrm{g} / \mathrm{g}$ dry weight (Friant, 1979).

Although some copper could enter the CBP with the source water, the primary source of elevated copper concentrations observed in CBP biota is probably from copper sulfate used as an algicide in the crnals. Elevated concentrations in the biota collected from Billy Clapp Lake are probably related to copper sulfate applied to Main Canal upstream of the lake. Of all the sit ss where the biota was collected, Billy Clapp Lake had the largest copper concentrations in perch and coots and the second largest concentration in pondweed; however, these concentrations were not significantly larger than those f-om other sites. In snails collected from Billy Clapp Lake, the mean copper concentration was significantly $(p=0.0013)$ less than in snails from other sites.

\section{Mercury}

Mercury concentrations in CPP biota were considerably less than concentrations repored in a variety of studies (Schmitt and Brumbaugh, 1990: Lowe and others, 1985; Fimreite, 1979; and Heinz, 1979) to be elevated or observed to cause adverse effects (table 20). CBP biota did show some evidence of biomagnification (accumulation of progressively larger concen trations by successive trophic levels of a food chain) of mercury. Mercury was not detected in plants, snails, or in eggs of the omnivorous mallards. However, mercury was detected in at least half of the fish collected as well as in the fish-eating grebes and their eggs. Mercury concentrations in grebe juveniles were almost twice as large as in coot juveniles, which feed on plants and some invertebrates. 1 Aercury concentrations were generally higher in carp than perch. Mercury can be biomagnified in food chains, and th e predatory perch might be expected to contain greater concentrations than the omnivorous carp. Higher concentrations in carp could be due to their greater size and age relative to the perch. Longer-lived individuals would accumulate relatively more mercury over time, and large- size requires the ingestion of more biomass, although, in the case of the carp, the food items would be lower on the food chain. Compared with other sites sampled in this study, large mercury concentrations were observed in carp and perch samples from Lind Coulee Wasteway. The data collected during this study indicated that mercury concentrations in fish have not changed appreciably since 1985 . Although 


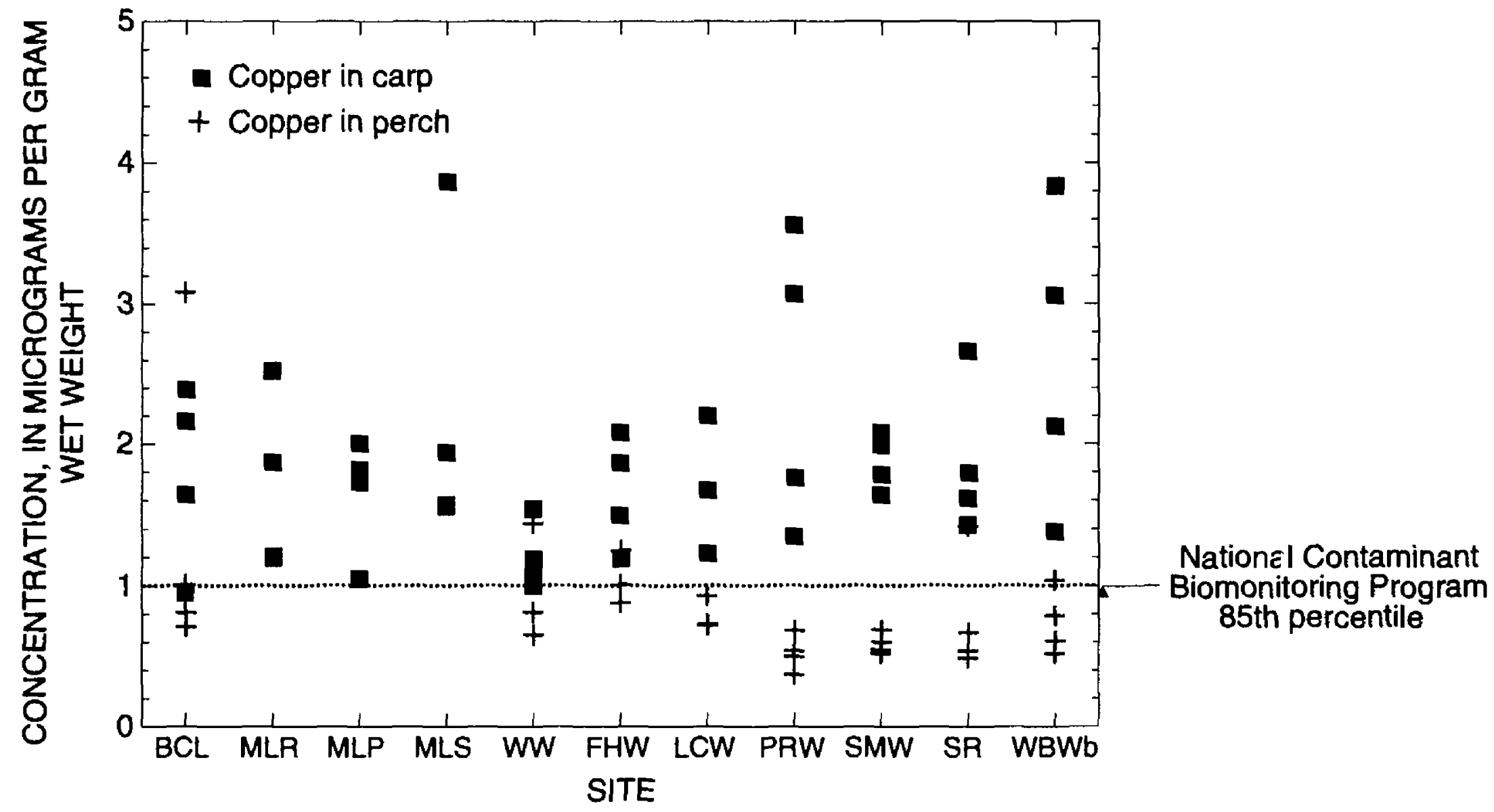

Figure 13.--Concentrations of copper in fish samples from the Columbia Basin Project. Site abbreviation is map identifier (fig. 9); see text page 22 for explanation of map identifers. 


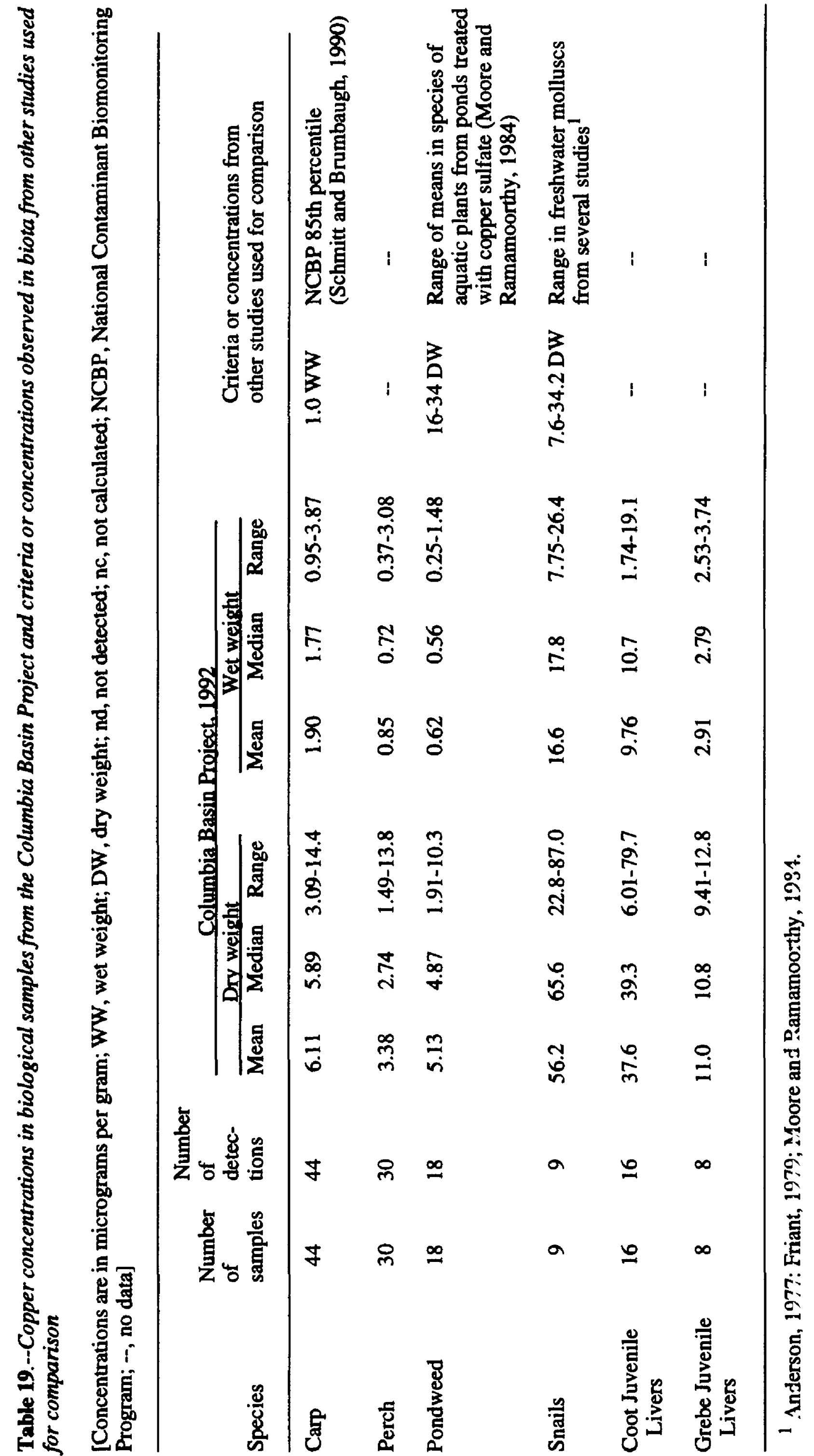




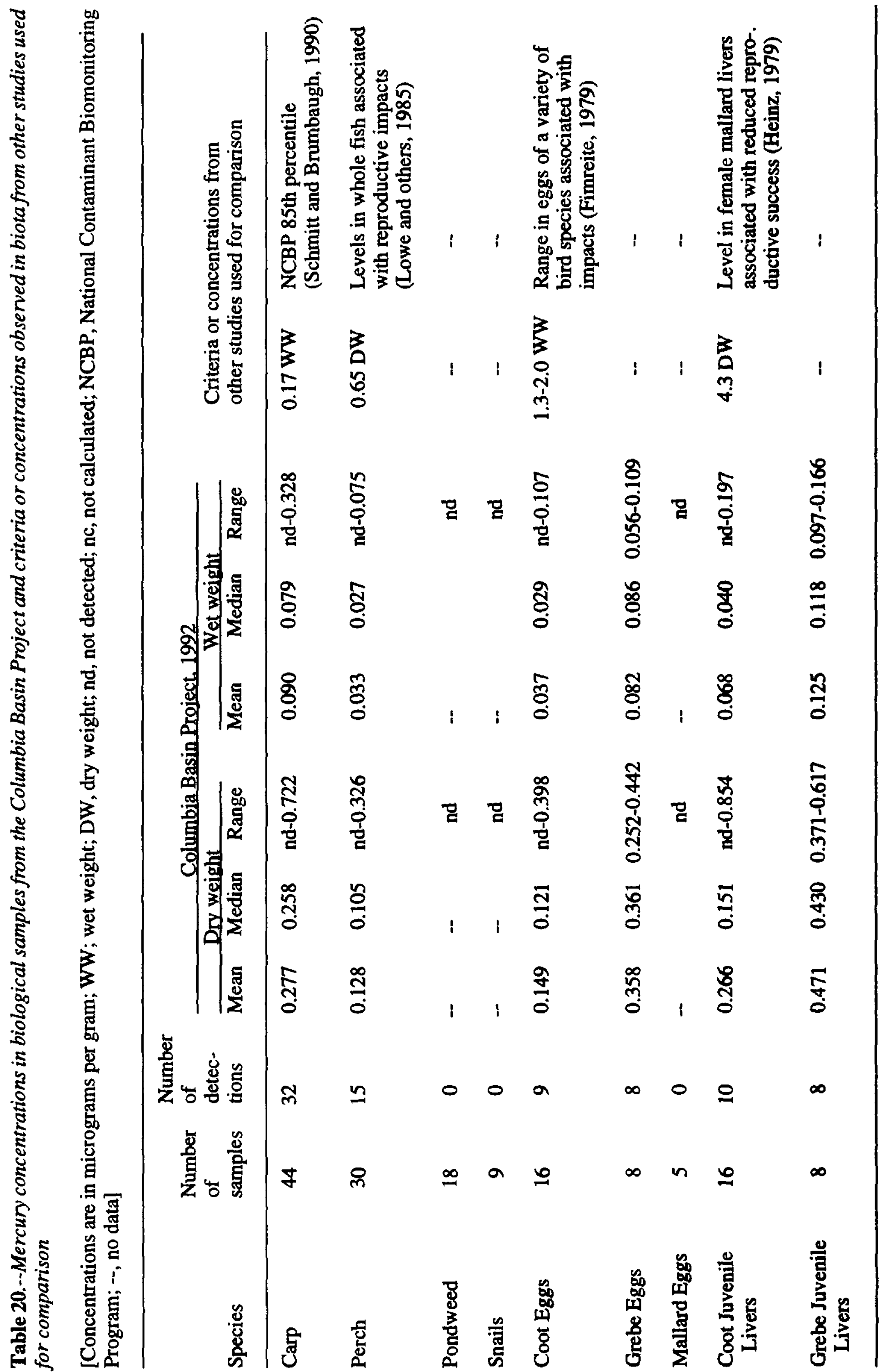


the maximum concentration in $1992(0.328 \mu \mathrm{g} / \mathrm{g}$ wet weight) was considerably larger than in $1985(0.06 \mu \mathrm{g} / \mathrm{g}$ wet weight, Block, 1993), the means were similar.

\section{Selenium}

Selenium was not present in CBP biota in concentrations indicated by other investigators (Schmitt and Brumbaugh, 1990; Sorenson and Schwarzbach, 1991; Skorupa and others, 1991; San Joaquin Valley Drainage Program, 1990; and Eisler, 1985) to be levels of concern (table 21). Also, the data indicated that selenium concentrations in fish collected in 1992, ranging from 0.18 to $1.0 \mu \mathrm{g} / \mathrm{g}$ wet weight, have not changed appreciably since 1985 when the concentrations ranged from 0.19 to $0.87 \mu \mathrm{g} / \mathrm{g}$ wet weight (Block, 1993). In this study, mean selenium concentrations in all biological samples (except pondweed) collected from Wahluke Branch Wasteway Lake and Saddle Mountain Wasteway were approximately 1.5 times larger than concentrations in biota collected from the other sites.

\section{Organic Compounds}

Of the synthetic organic compounds, chemical analysis was limited to the organochlorine pesticides and other selected organochlorine compounds that accumulate in tissues of biota. Concentrations of organochlorine compounds in fish collected in 1992 in the CBP were compared with criteria for concentrations in whole fish established by the NAS/NAE (1973) to protect the health of fish and fish-eating wildlife. Organochlorine-compound concentrations in biological samples other than fish were compared with results from other studies. Because organochlorine compounds in fish from the CBP have been monitored since 1977, concentrations were examined for changes over time. The analytical results for the organochlorine pesticides and other organochlorine compounds (pesticide degradation products and PCBs) are given in units of wet weight and listed in table 33 at the end of the report. In this section, only those compounds that were found in CBP biota in elevated concentrations are discussed.

Organochlorine compounds were detected in most of the biological samples. Of all the pesticides analyzed for, DDT, chlordane, and dieldrin were most frequently detected in the biological samples; endrin, hexachlorobenzene (HCB), benzene hexachloride (BHC), and methoxychlor were occasionally detected. Concentrations of the compounds or pesticides mostly were small except that fish samples collected from some of the sites exceeded
NAS/NAE criteria. Lind Coulee Wasteway and Scooteney Reservoir fish contained the largest mean concentrations of the pesticides commonly observet during the study-total DDT, total chlordane, and dieldrin. Historically, fish from these sites have larger concent ations of organochlorine pesticides than fish from other CBP area sites (Washington State Department of Social and Health Services, 1977, 1978, 1979; Block, 1993). Th a fish collected from Lind Coulee Wasteway and Scooteniy Reservoir also contained a greater variety of organochl orine compounds than the other sites and included pesticides observed less frequently during the study: endrin, $\mathrm{H} C \mathrm{~B}, \mathrm{BHC}$, and methoxychlor. The elevated concentraticns of pesticides at these sites could be due to soil erosion caused by gravity irrigation.

Total DDT is the sum of the $p, p^{\prime}$ and $o, p^{\prime}$ isomers of DDE, DDD, and DDT. Concentrations of total DDT in 6 of 44 carp exceeded the NAS/NAE criterion of $1.0 \mu \mathrm{g} / \mathrm{g}$. Elevated concentrations of as much as $2.49 \mu \mathrm{g} / \mathrm{g}$ total DDT were found in fish collected from Frenchman Hills Wasteway, Lind Coulee Wasteway, Scooteney Reservoir, and Moses Lake-Rocky Ford arm. Except for one perch sample, the proportion of the $o, p^{\prime}$ is omers of DDT were more than 20 percent of the $p, p^{\prime}$ isomers (fig. 14) in fish collected from Saddle Mountain Wasteway. Because the $o, p^{\prime}$ isomers of DDT are much less persistent in the environment than the $p, p^{\prime}$ isomers, Schmitt and others (1990) proposed that the proportion of the isomers in biological samples might indicate release of unnetabolized DDT into the environment subsequent to the 1972 ban on DDT usage. On the basis of results of monitoring programs and the chemical characteristics of DDT, the investigators suggested that a proportion of more thar 20 percent $o, p^{\prime}$ isomers could indicate post-1972 injut of DDT from a variety of possible sources. However, except possibly agricultural soils, which can retain rnmetabolized DDT, no other sources of DDT are known to exist in the Saddle Mountain Wasteway area.

Total chlordane is the sum of the concentrations of cis-chlordane, trans-chlordane, heptachlor, cis-nonachlor, trans-nonachlor and the miscellanecus constituents and degradation-products (Eisler, 1985c). Concentrations of total chlordane in 10 of the 44 carp samples exceeded or equaled the NAS/NAE criterion of $0.1 \mu \mathrm{g} / \mathrm{g}$. In perch, none of the 30 samples exceeded this criterion (table 22). The elevated concentrations of as m" $\mathrm{ch}$ as $0.18 \mu \mathrm{g} / \mathrm{g}$ total chlordane in carp were observed in fish collected from Frenchman Hills Wasteway, Lind Cisulee Wasteway, Potholes Reservoir in west arm, Sccoteney Reservoir downstream from EL68D Wasteway, and Saddle Mountain Wasteway. 


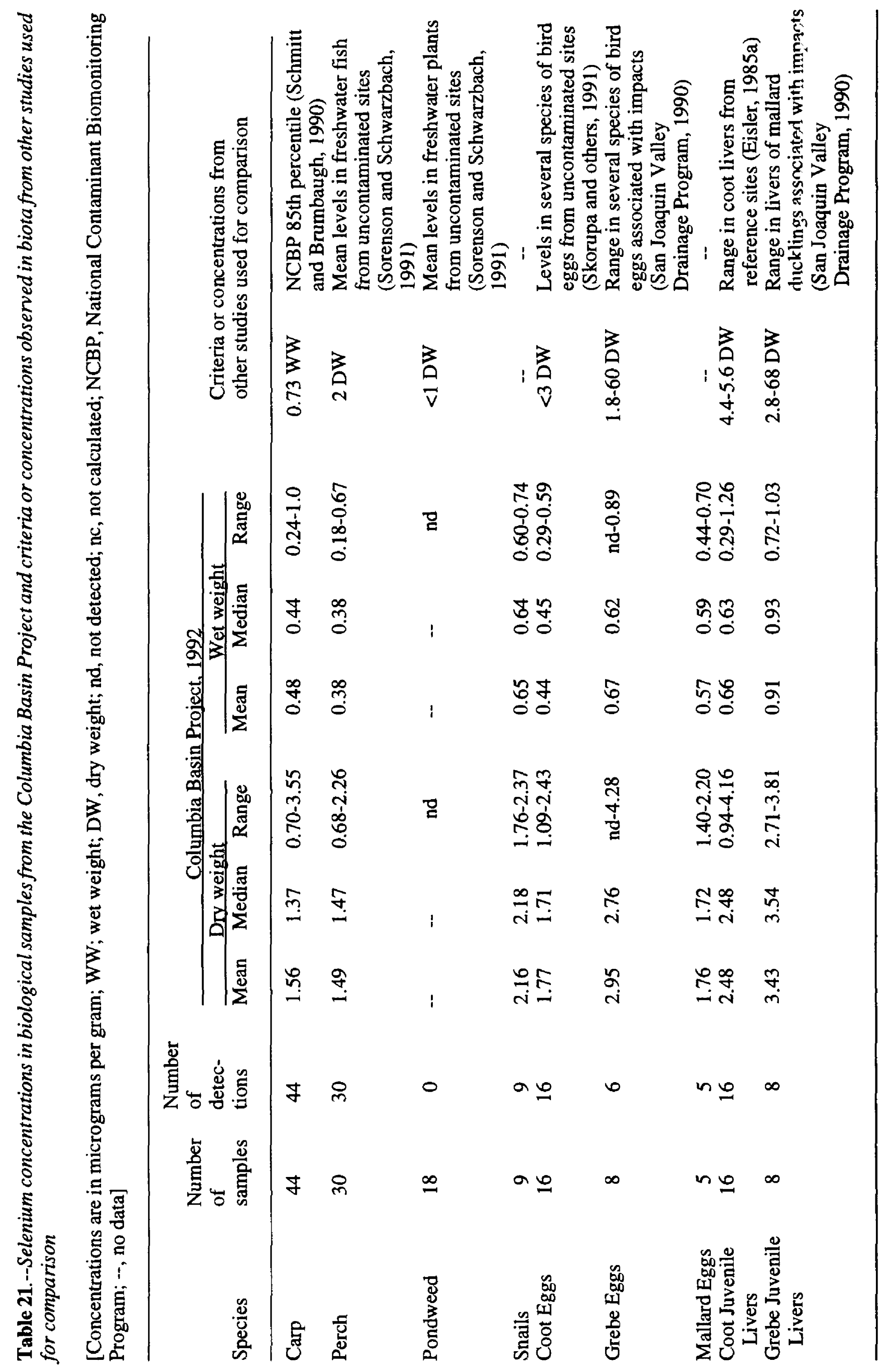




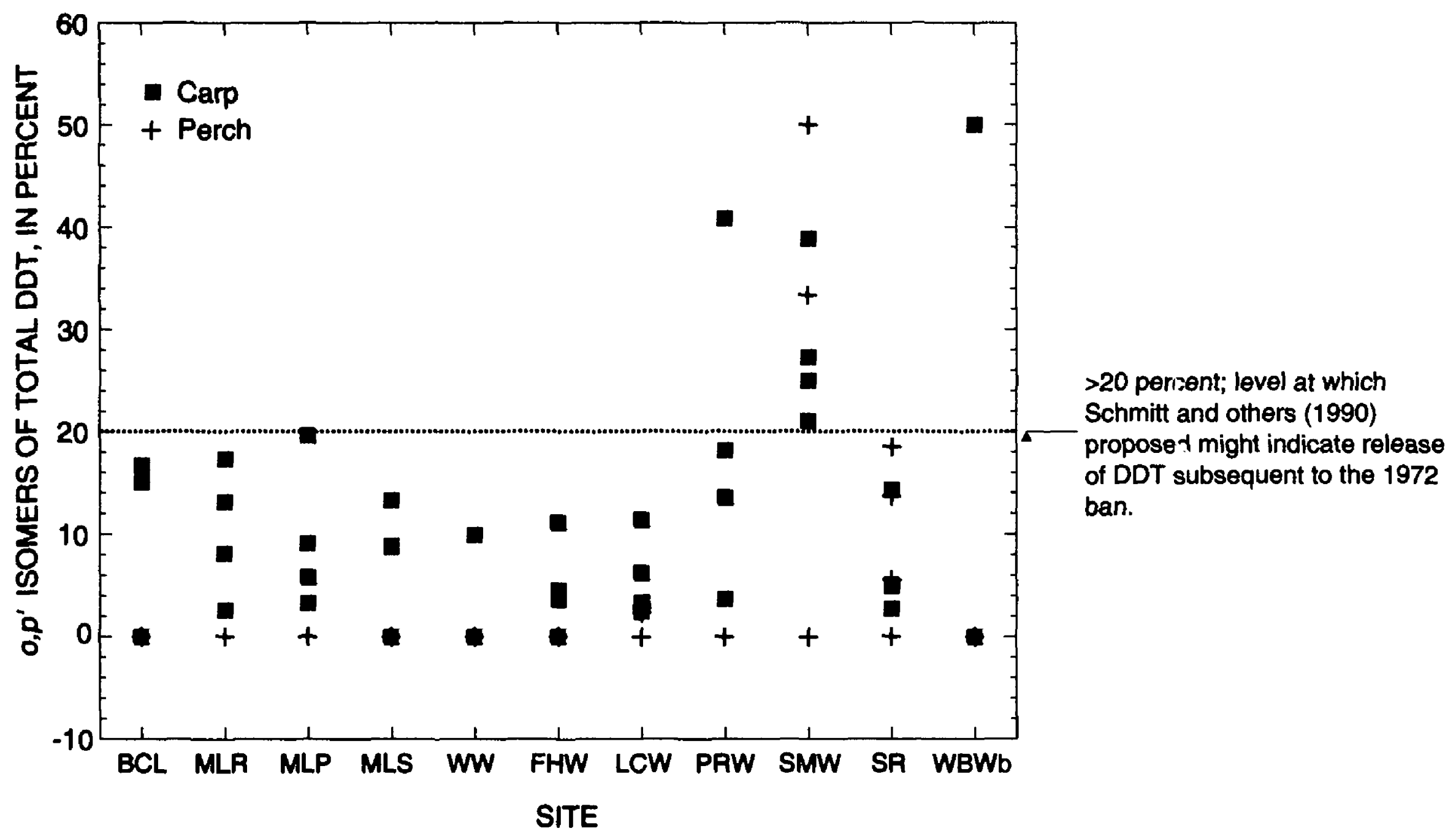

Figure 14.--Proportion of the $0, p^{\prime}$ isomers of total DDT to the $p, p^{\prime}$ isomers of total DDT in carp and perch samples from the Coumbia Basin Project. Site abbreviation is map identifier (fig. 9); see text page 22 for explanation of map identifiers. 


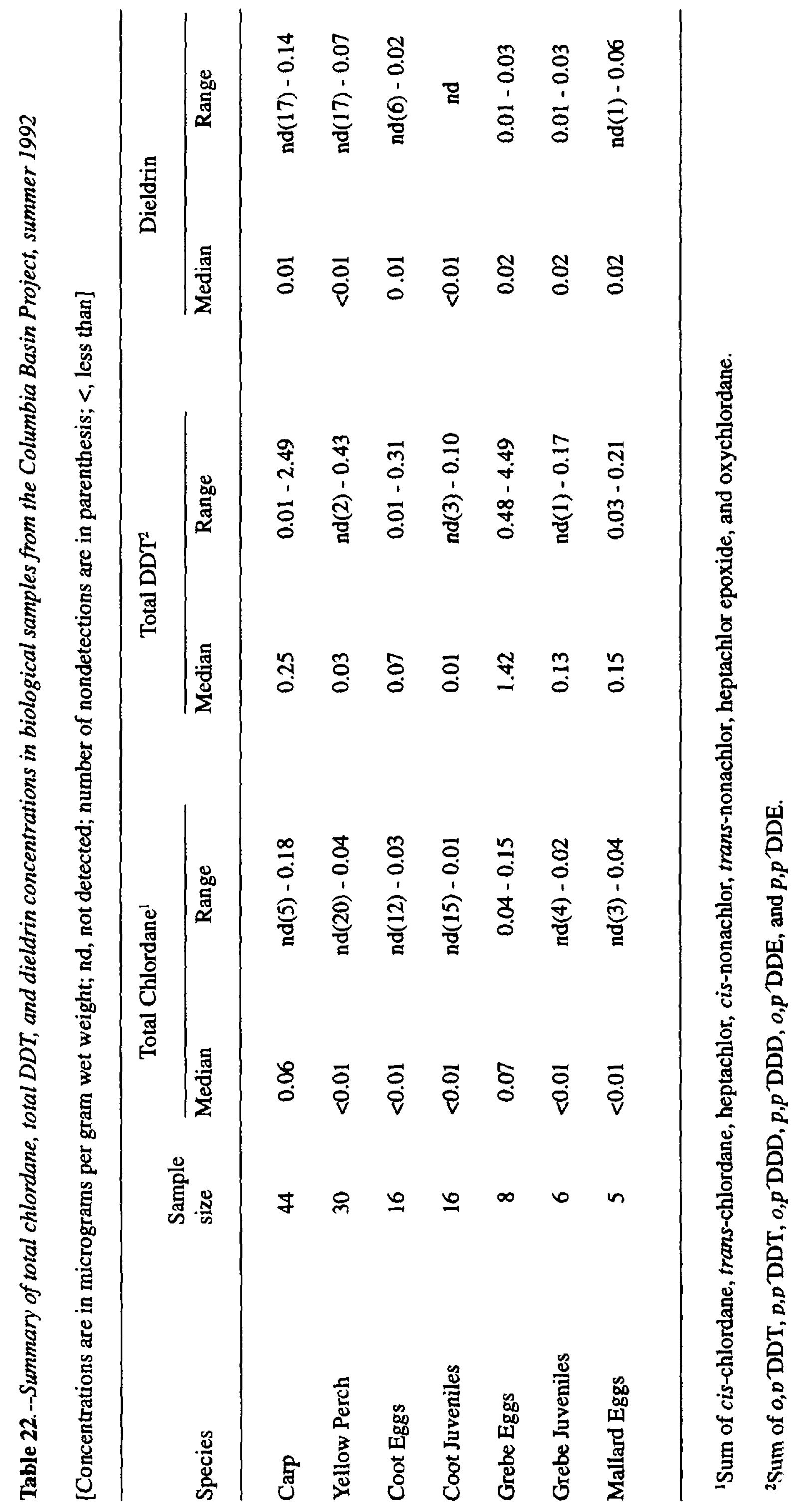


Concentrations of dieldrin in 3 of 44 carp samples exceeded the NAS/NAE criterion of $0.1 \mu \mathrm{g} / \mathrm{g}$ wet weight. Elevated concentrations of as much as $0.14 \mu \mathrm{g} / \mathrm{g}$ wet weight occurred in carp collected from Lind Coulee Wasteway and Frenchman Hills Wasteway. No perch samples contained dieldrin in concentrations that exceeded the NAS/NAE criteria. Dieldrin concentrations in the juvenile western grebes and in the grebe eggs both ranged from 0.01 to $0.03 \mu \mathrm{g} / \mathrm{g}$ wet weight, with a mean of $0.02 \mu \mathrm{g} / \mathrm{g}$ wet weight. Typically, the concentrations of the organochlorine compounds in juvenile birds are less than concentrations in the eggs because the contaminants passed on to the egg from the maternal body burden are diluted by nestling growth, metabolic breakdown, and excretion (Charnetski, 1976; Fimreite and Bjerk, 1983). The reasons are unknown why dieldrin concentrations were the same in the samples of the grebe juveniles and grebe eggs collected in this study.

In concentrations of as much as $0.05 \mu \mathrm{g} / \mathrm{g}$ wet weight, methoxychlor was detected in 14 of 44 carp and in 2 of 30 perch collected in the CBP. Carp collected from Frenchman Hills Wasteway, Moses Lake, Potholes Reservoir, and Saddle Mountain Wasteway contained methoxychlor; both carp and perch collected from Lind Coulee Wasteway and Scooteney Reservoir contained methoxychlor. The concentrations in the carp were elevated and found more frequently than in a nationwide monitoring program (U.S. Environmental Protection Agency, 1992b). One source of the methoxychlor could be mosquito-control spraying.

Concentrations of total PCBs were not detected in the biota collected from the CBP, except in one coot egg and in seven of eight grebe eggs (see table 33). In concentrations ranging from less than 0.05 to $3.4 \mu \mathrm{g} / \mathrm{g}$ wet weight, the PCBs in the grebe eggs were probably from PCBs accumulated in the maternal body burden at the birds' wintering areas away from the CBP area.

\section{Changes in Organochlorine-Pesticide Concentrations Over Time}

Concentrations of organochlorine pesticides in fish from this study were compared with concentrations in carp and perch samples collected and analyzed by the BR in 1977 and 1978 (Washington State Department of Social and Health Services, 1977, 1978, 1979) and the U.S. Fish and Wildlife Service in 1982 and in 1985 (Block, 1993). Only samples collected from Billy Clapp Lake, Lind Coulee Wasteway, Frenchman Hills Wasteway, Winchester Wasteway, Scooteney Reservoir, and Moses Lake were compared. Between-year differencer in concentrations were tested for mean total DDT and dieldrin in carp and perch using the General Linear Models (GLM) procedure, with pairwise comparisons made using Duncan's Multiple Range test (SAS Institute, Inc., 1988). There are limitations to comparing these different sets of data. First, although the water bodies of the 1985 collection are the same as those of the previous collections, the specific locations where individual fish were collected are unknown, and the 1985 data include fish collec ${ }^{4}$ ed from sites other than the six sites listed above. Secord, little or no quality assurance information is available for the data collected during the late 1970's and early 1980's. Third, analytical methods have changed; specifically, capillary column chromatography replaced packed-column gas chromatography.

Concentrations of total DDT (fig. 15) in fish (carp and perch) showed little change over the past 15 years. This lack of change is contrary to the significant decline in concentrations of DDT compounds cbserved between 1976-79 and 1984 in nationwide monitoring programs (Schmitt and others, 1990). Total DDT concentrations in two carp collected during this study in 1992 were among the largest total DDT concentrations recorded for the CBP. The 1992 concentrations of total $\mathrm{DD}^{-m}$ in the carp appeared to be generally elevated throughout the CBP area.

Chlordane was detected infrequently during the earlier studies, so trends over time were examined using the percent of samples that had detectable concentrations of chlordane. In 1992, about 70 percen* of samples had detectable chlordane compared with earlier years with detections ranging from about 0 to 30 percent. The 1992 concentrations of chlordane in fish were increased over previous concentrations as well. Prior to 1992, the largest observed concentration of total chlor lane was $0.07 \mu \mathrm{g} / \mathrm{g}$, whereas in 1992, concentrations in several carp samples were at least twice the historical value.

\section{Dioxins and Furrns}

Dioxins and furans are found ir elevated concentrations in FDR Lake, the source of water for the CBP. The primary compounds detected in FDR Lake sediment and in several species of fish are TCDD and TCDF (Johnson and others, 1991a, b). Four whole-body longnose suckers collected from Billy Clapp Lake wer: analyzed for TCDD and TCDF to determine whether diovins and furans are entering the CBP with the source water. TCDD was not detected in the suckers; but small corcentrations of TCDF, ranging from 2.04 to $2.21 \mathrm{pg} / \mathrm{g}$ (pico?̣rams per gram), 


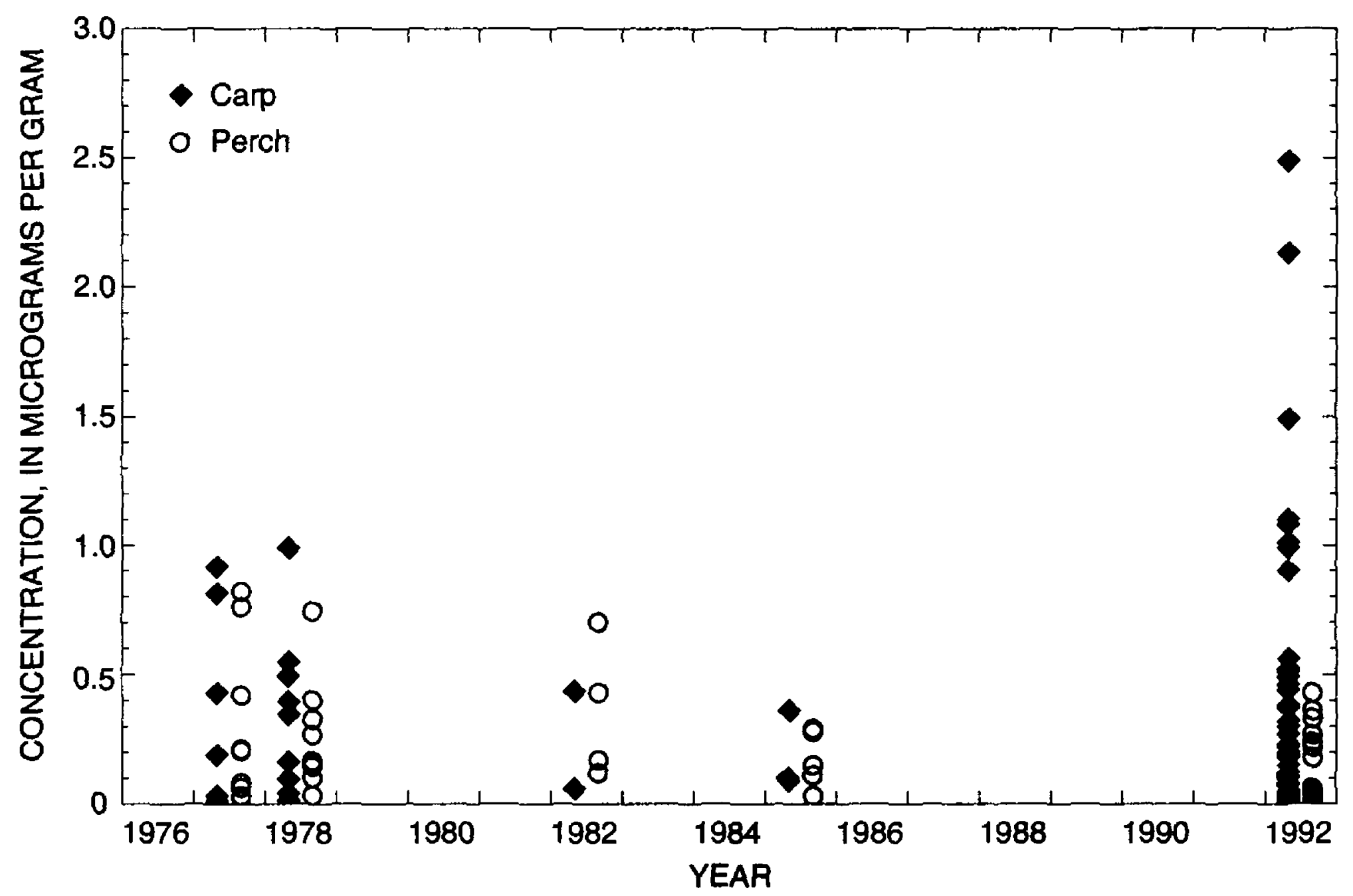

Figure 15.--DDT concentrations in fish samples collected from the Columbia $E$-sin Project during 1977-85 and in 1992. 
were detected (table 23). These concentrations of TCDF are within the range of concentrations (from 0.10 to $13.73 \mathrm{pg} / \mathrm{g}$ ) for 34 reference sites in a nationwide study of dioxins in both whole fish and fillets (U.S. Environmental Protection Agency, 1992b).

The concentrations of dioxin and furan compounds in biological tissues are also expressed in terms of toxicity equivalents (TEQ). The TEQ allows for toxicity of the different dioxin and furan congeners to be expressed in a single toxicity term. The development of the TEQ resulted from several studies (Bellin and Barnes, 1987; Olson and others, 1989; Barnes and others, 1989) that documented relatively consistent toxicities for the different congeners of dioxin and furan. The most toxic congener, TCDD, was assigned a toxicity factor of 1 , and other congeners were assigned toxicity factors of less than 1, based on their reduced toxicity relative to TCDD. To calculate $T E Q$, the concentration of each congener in a sample was multiplied by the toxicity factor, and the products were summed.

For this study, TEQ was calculated as follows. TCDF was the only congener detected, and TCDF concentrations were multiplied by a toxicity factor of 0.1 .

Although TCDD was not detected, concentration was calculated as one-half of the detection limit, and multiplied by a toxicity factor of 1 . The following equation was used to calculate TEQ:
$\mathrm{TEQ}=(\mathrm{TCDF}$ concentration $\times 0.1)+((\mathrm{TCDD}$ detection limit $\times 0.5) \times 1$ )

The TEQs in whole-body suckers from Billy Clapp Lake ranged from 0.38 to $0.54 \mathrm{pg} / \mathrm{g}$, and were considerably less than the preliminary health advisory criterion of $11.4 \mathrm{pg} / \mathrm{g}$ for human consumption of fish fillets established by the British Columbia Ministry of Environment (1990) for the Columbia River.

The data for the suckers indicate that TCDF has entered Billy Clapp Lake; the source of TCDF might be imported water from FDR Lake or atmospheric deposition. It is unknown whether concentrations of TCDF in fish have had or could have harmfil effects, although recent research has documented effects on fish at TEQ concentrations of 1 to $65 \mathrm{pg} / \mathrm{g}$ (Johrson and others, 1991a). The effects range from act "ration of enzymes that metabolize organic compounds in the liver so they can be excreted, to the mortality of fish egrs and fry.

\section{Other Biological Assessmerts}

Measurements of biological effects, other than those inferred by comparing concentraticns of contaminants in the tissues, were also made during this study. Bioassays provide direct, quantifiable measuroments of effects from toxic compounds or conditions in vater or sediment.

Table 23.--Concentrations of dioxins and furans in whole longnose suckers collected from Billy Clapp Lake (site $B C L), 1992$

[Concentrations are in parts per trillion wet weight; nd, not detected; TCDD, 2,3,7,8-tetrachlorodibenzo-p-dioxin; TCDF, 2,3,7,8-tetrachlorodibenzofuran; TEQ, Toxicity equivalent of TCDD: TEQ=(TCDF x 0.1)+((TCDD detection limit $\times 0.5) \times 1)]$

\begin{tabular}{llcccccc}
\hline $\begin{array}{l}\text { Sample number } \\
\text { (figure 9) }\end{array}$ & TCDF & TCDD (detection limit) & TEQ & $\begin{array}{l}\text { Percent } \\
\text { lipid }\end{array}$ & $\begin{array}{l}\text { Fish } \\
\text { weight } \\
\text { (grams) }\end{array}$ & $\begin{array}{l}\text { Fish } \\
\text { length } \\
\text { (centimeters) }\end{array}$ \\
\hline BCLLNC01 & 2.04 & nd & $(0.676)$ & 0.54 & 5.17 & 1,017 & 42.2 \\
BCLLNC02 & 2.06 & nd & $(0.343)$ & 0.38 & 7.56 & 794 & 39.3 \\
BCLLNC03 & 2.14 & nd & $(0.408)$ & 0.42 & 8.29 & 1,200 & 42.1 \\
BCLLNC04 & 2.21 & nd & $(0.314)$ & 0.38 & 6.05 & 581 & 36.6 \\
\hline
\end{tabular}


More subtle impacts can be assessed by examining organisms for deleterious effects or indicators of effects. Most of these methods indicate that ambient conditions are causing impacts, but are not easily quantified and provide little or no information on specific contaminants or waterquality conditions. For example, the frequency of external lesions in fish can provide an index to the health of a population of fish, but the specific cause of the lesions is generally not known. Some indicators are related to specific contaminants. For example eggshell thinning in birds, and resulting reductions in reproductive success, are predominantly related to DDE exposure.

\section{Bioassays}

Two organisms were exposed to surface water to assess toxicity: Daphnia magna and the Microtox bacteria. Bioassays using Daphnia showed no toxicity statistically greater than the control tests for all sites and all sampling periods. Microtox bioassays also showed no toxicity for all sites and all sampling periods.
One organism, the larval midge C.ironomus tentans, was exposed to bottom sediment to assess toxicity. Midge larvae exposed to the bottom sediment from 9 of 21 sites lost a significant amount of body weight compared with the controls indicating a degree of toxicity (table 34). Graphical analysis of the data showed ro relation between the degree of sediment toxicity and concentrations of constituents except for a weak relation betreen toxicity and the concentrations of arsenic and methoxychlor.

\section{Eggshell Thickness}

One of the effects of DDE and a few other organochlorine compounds on birds is eggs hell thinning. In a study of black-crowned night-herons, Finny and others (1984) described eggshell thinning in e rgs containing $1.0 \mu \mathrm{g} / \mathrm{g}$ of DDE. Measurements made in 1992 on the shells of western grebe, mallard, and ccot eggs were compared with measurements of eggshell th icknesses made prior to DDT use (pre-1947) (table 24). Based on the

Table 24.--Eggshell thickness for coot, mallard, and western grebe eggs collected from the Columbia Basin Project in 1992 and thickness of eggs collected before the use of DDT (before about 1940)

[Thickness is in millimeters; --, no data]

Eggshell thickness

\begin{tabular}{|c|c|c|c|c|}
\hline Species & $\begin{array}{l}\text { Number } \\
\text { of samples }\end{array}$ & Range & Mean & $\begin{array}{r}\text { Pre-DD } \\
\text { Mea }\end{array}$ \\
\hline \multicolumn{5}{|l|}{ American Coot } \\
\hline Billy Clapp Lake (BCL) & 8 & $0.296-0.364$ & 0.339 & -. \\
\hline Moses Lake (MLS) & 8 & $0.350-0.394$ & 0.367 & -- \\
\hline Saddle Mountain Wasteway (SMW) & 8 & $0.315-0.362$ & 0.340 & -- \\
\hline Winchester Wasteway (WW) & 8 & $0.313-0.370$ & 0.336 & -- \\
\hline \multicolumn{5}{|l|}{ Western Grebe } \\
\hline Potholes Reservoir, west arm (PRW) & 8 & $0.426-0.528$ & 0.461 & ${ }^{a} 0.385$ \\
\hline Potholes Reservoir, east arm (PRE) & 8 & $0.380-0.481$ & 0.426 & ${ }^{a} 0.385$ \\
\hline \multicolumn{5}{|l|}{ Mallard } \\
\hline Moses Lake (MLS) & 10 & $0.332-0.403$ & 0.359 & $\mathrm{~b}_{0.349}$ \\
\hline
\end{tabular}

\footnotetext{
${ }^{a}$ Mean for western grebe eggs (Boellstorff and others, 1985).

${ }^{b}$ Mean for mallard eggs (Blus and Henny, 1985).
} 
measurements of shells from western grebe and mallard eggs, eggshell thinning does not appear to be a problem in the CBP. The eggshells of the CBP grebes showed no evidence of thinning, although DDE concentrations in the eggs were as much as $4.24 \mu \mathrm{g} / \mathrm{g}$. Thickness means of 0.461 and $0.426 \mathrm{~mm}$ for western grebe eggshells from Potholes Reservoir were greater than the pre-1947 mean eggshell thickness of $0.385 \mathrm{~mm}$ for 24 western grebe eggs collected in Northern California and Oregon (Boellstorff and others, 1985). The eggshells of the CBP mallards also showed no evidence of thinning. The mean eggshell thickness of $0.359 \mathrm{~mm}$ for the mallards was similar to the pre-1947 mean of $0.349 \mathrm{~mm}$ for 14 mallard eggshells reported by Blus and Henny (1985). Pre-1947 data on eggshell thickness for coots were not available for comparison.

\section{Visible Abnormalities in Bird Embryos and Fish}

During the preparation of the eggs collected for subsequent chemical analysis, all embryos were visually examined for gross abnormalities. No abnormalities were observed in the mallard eggs, most of which were well developed. Also, no abnormalities were observed in coot or western grebe eggs; however, many of these eggs were in early stages of development, making it difficult to detect abnormalities. All the captured fish were examined for external lesions. In general, lesions were uncommon (from 0 to 14 percent of the total catch).

\section{SUMMARY}

The reconnaissance study of the irrigation area of the Columbia Basin Project (CBP) was a part of the U.S. Department of Interior's National Irrigation Water Quality Program (NIWQP). Because of concerns expressed by the U.S. Congress, the Department of the Interior initiated the NIWQP in 1985 to identify the nature and extent of any irrigation-induced water-quality problems for which the DOI might have responsibility in the western States. The CBP was selected for a reconnaissance-level study because of concerns that concentrations of constituents associated with irrigation drainage might be adversely affecting biota in the more than 223,400 acres of wildlife areas of the CBP.

The Columbia River is the major source of water for the irrigation of 575,000 to 580,000 acres in the CBP. Water impounded in Franklin D. Roosevelt (FDR) Lake by Grand Coulee Dam is pumped into Banks Lake at an average annual rate of about 3,600 cubic feet per second. For crop irrigation, water is moved from Banks Lake into and through the study area by numerous siphons, tunnels, canals, wasteways, and natural drainage features. Water is usually released for irrigation beginr ing in early March and ending in late October. In addition to irrigation, the imported water is used for recreation, wildlife habitat, and in-stream support of aquatic life. Irr gation has both eliminated and improved wildlife habitat. Vast acreages of shrub-steppe habitat have been eliminated by conversion to agriculture or degraded by grazing. However, increased amounts of surface water have improved the habitat value of some of the remaining shrub-steppe areas, and greatly increased the acreage of wetlands ant the populations of those species associated with wetlan ts.

A total of 24 sampling sites wer located on 21 major surface-water features to assess the cuality of surfacewater, irrigation-return flows, and bcttom sediment with respect to fish and wildlife management areas in the CBP. Billy Clapp Lake, part of the Main C.nal delivery system of irrigation water from the Columbia River, served as the study's reference site. Sampling sites on two perennial streams included one site on Rocky Ford Creek and three sites on Crab Creek--one on Upper Crab Creek before it enters Moses Lake, one downstream from Potholes Reservoir, and one on Crab Creek near Beverly near the confluence with the Columbia River. In addition to Crab Creek, sites were located on Sand Hollow Craek (RB4C Wasteway), which also discharges return $\mathrm{fl}$ : w into the Columbia River. Samples were collected from three sites on Moses Lake--Rocky Ford arm, Parker Horn arm, and in the south end near the gaging station at Moses Lake.

Potholes Reservoir collects and stores surface water, ground water, and return flows from the northern part of the CBP for redistribution into the scuthern part. Samples were collected in the west arm and east arm of Potholes Reservoir and from sites on each of the three major wasteways that empty into the reservoir--W'inchester, Frenchman Hills, and Lind Coulee Wasteways. Downstream from the reservoir, samples were col' 'acted from Soda Lake, which is part of the Potholes Canal system, and from Lower Goose Lake, which coll mts water from the terminus of West Canal.

Sampling sites on the major wasteways in the southern part of the CBP were PE16.4 Wasteway and Esquatzel Coulee Wasteway. Three water feat ures in the southern part of the CBP each had sampling points located in a flowing section of the wasteway and downstream in the quiescent water of a lake that receives the wastewater. Water samples were collected in the flowing sections and bottom sediment and biota were collected in the lakes. 
Saddle Mountain Wasteway was sampled at points on its inflow to a lake and also at points within the lake or along the lakeshore. In the Wahluke Wildlife area, a small lake was sampled for bottom sediment and biota and is referred to as site Wahluke Branch Wasteway Lake in this report.

This lake collects return flows from both Wahluke Branch 10A Wasteway, which was sampled for water, and Wahluke Branch 10 Wasteway. EL68D Wasteway was sampled for water and bottom sediment at its confluence with Potholes Canal, which discharges into Scooteney Reservoir; biota was collected from Scooteney Reservoir near where Potholes Canal discharges into the lake.

Water samples were collected at 15 primary surface-, lake-, and wasteway water features during three periods: November 1991 after-irrigation season; March 1992 before-irrigation season; and July 1992 during-irrigation season. At six secondary water features, water samples were collected only during the irrigation season. Bottomsediment samples were collected from all 21 water features, but only during the irrigation season. Biologicalsample collection began in May 1992 and continued throughout the irrigation season.

Concentrations of dissolved constituents, including nutrients and trace elements, were typically small and, with few exceptions, did not exceed various standards and criteria protecting humans and freshwater life. The concentrations of most of the dissolved constituents varied spatially and seasonally. They generally increased in a downstream direction corresponding to water reuse as the water moves through the irrigation project, and they tended to be large during non-irrigation season when ground water, with a large dissolved constituent load, sustains stream baseflows.

Dissolved-solids concentrations exceeded the irrigation criterion of $500 \mathrm{mg} / \mathrm{L}$ only in water samples collected during non-irrigation season from Wahluke Branch $10 \mathrm{~A}$ Wasteway, Crab Creek near Beverly, and EL68D Wasteway. Nitrate concentrations, like dissolved solids, increased in a downstream direction and exhibited similar seasonal variation. During non-irrigation season, nitrate concentrations at some wasteway sites were larger than during irrigation season. Seasonal variation in nitrate concentrations probably indicates that nitrogen from crop fertilizer has leached from the soils into tile drains and the shallow ground-water system and entered the stream channel as base flows. During irrigation season, nitrate concentrations were small when the large volume of dilute Columbia River water dominated streamflows. The median nitrate concentration of $1.7 \mathrm{mg} / \mathrm{L}$ was more than four times the national baseline value of $0.41 \mathrm{mg} / \mathrm{L}$.
Median trace-element concentrations were small and some were less than analytical reporting limits. Because most of the samples had concentrations that did not exceed various protection criteria for drinking, aquatic life, or irrigation, the trace elements in CBP water generally would not appear to threaten human or wildlife health. Concentrations of cadmium, chromium, lead, rercury, and selenium were less than analytical reporting limits in a majority of 51 samples. Concentrations of boron, molybdenum, uranium, and vanadium were larger in wasteways with large percentages of reused water than in surfacewater features with less extensively reu ed water. The median concentrations were $20 \mu \mathrm{g} / \mathrm{L}$ for boron, $2 \mu \mathrm{g} / \mathrm{L}$ for molybdenum, $2.4 \mu \mathrm{g} / \mathrm{L}$ for uranium, and $12 \mu \mathrm{g} / \mathrm{L}$ for vanadium. Two factors control and minimize trace-element concentrations in the water of the CBP: (1) The CBP is largely a flow-through system with only a few terminus collection ponds or lakes where constitvents can become concentrated through evaporation; and (2) the large quantity of imported Columbia River water dilutes constituent concentrations that typically accumulate in irrigation drainage.

Of the other trace elements determined in water samples, about 10 percent of the arsenic concentrations were less than the reporting limit, and none exceeded USEPA standards or criteria. Chromium was detected in only three samples collected during the study and copper concentrations were equal to or less than the analytical reporting limit of $1 \mu \mathrm{g} / \mathrm{L}$ in 86 percent of the samples. One lead concentration of $29 \mu \mathrm{g} / \mathrm{L}$ and one mercury of $3 \mu \mathrm{g} / \mathrm{L}$ were particularly large, but could be incorrect due to analytical or sampling errors. Only three samples collected during this study had selenium concentrations greater than the analytical reporting limit of $1 \mu \mathrm{g} / \mathrm{L}$; the maximum concentration of $4 \mu \mathrm{g} / \mathrm{L}$ determined in the March sample from EL68D Wasteway is within the range of concentrations that can adversely affect fish. Selenium concentrations in the March samples from PE16.4 Wasteway and Esquatzel Coulee Wasteway were $2 \mu \mathrm{g} / \mathrm{L}$, also within the range of concern. Although numerous sources of zinc exist in the Columbia River watershed, zinc concertrations in CBP water samples were considerably less than the USEPA's freshwater criterion of $110 \mu \mathrm{g} / \mathrm{L}$. They ranged from less than 3 to $13 \mu \mathrm{g} / \mathrm{L}$, with a median of $3.7 \mu \mathrm{g} / \mathrm{L}$.

Most of the different types of pest cides analyzed for in this study were not detected in 51 water samples. Of those detected, there were 18 positive detections of insecticides, such as chlorpyrifos, DDT (and its metabolic product, DDE), dieldrin, disulfoton, lindane, malathion, methyl parathion, and methoxychlor; and there were 31 positive detections of herbicides, such as dicamba, picloram, and 
2,4-D. Most of these detections were observed in samples collected in July during the irrigation season. The single detection of DDT $(0.002 \mu \mathrm{g} / \mathrm{L})$ and of methoxychlor $(0.07 \mu \mathrm{g} / \mathrm{L})$ and the maximum observed concentration of dieldrin $(0.014 \mu \mathrm{g} / \mathrm{L})$ exceeded USEPA chronic criteria for the protection of aquatic life. The herbicide 2,4-D was detected in samples more than any other pesticide; 26 samples, mostly collected during the irrigation season, had 2,4-D in concentrations ranging from 0.01 to $1.0 \mu \mathrm{g} / \mathrm{L}$. In general, pesticides were present in more variety and in more samples of water from EL68D Wasteway than from any of the other sites, however concentrations were small.

In the bottom-sediment samples, many of the trace elements of interest were present only in small concentrations. The median concentrations of most trace elements were within the baseline range of concentrations for soils in the western United States. Of all the trace elements analyzed for, only the maximum observed concentrations of selenium, uranium, and manganese exceeded the upper value of the baseline range. Both the maximum observed selenium and uranium concentrations were in the bottomsediment sample from Rocky Ford Creek.

A variety of organochlorine pesticides and related compounds were present in the bottom-sediment samples and they appear to be widespread throughout the CBP area. In samples from all sites except two, at least one insecticide was detected. More of the organochlorine compounds analyzed for were detected in the bottomsediment samples from Lower Goose Lake, Frenchman Hills Wasteway, Sand Hollow Creek, and EL68D Wasteway than from the other sites. Numerous detections of dieldrin (maximum, $3.6 \mu \mathrm{g} / \mathrm{kg}$ ), DDT (maximum, $4.0 \mu \mathrm{g} / \mathrm{kg}$ ), and DDE (maximum, $7.8 \mu \mathrm{g} / \mathrm{kg}$ ) indicated that these environmentally persistent compounds are still present in much of the CBP. DDE was detected in 18 of 21 samples; dieldrin and DDT were detected in 8 of 21 samples. Methoxychlor was found in samples from nine of the sites in concentrations as large as $2.4 \mu \mathrm{g} / \mathrm{kg}$.

Comparison of the results of trace element concentrations in bird tissues collected during the study with those of dietary exposure studies indicates that arsenic in coot livers and boron in pondweed were present in concentrations that might be harmful to waterfowl. Concentrations of arsenic as large as $9.25 \mu \mathrm{g} / \mathrm{g}$ dry weight in juvenile coot livers were similar to those in the livers of mallard ducklings adversely affected by consuming arsenicsupplemented meal given during laboratory studies. The amount of boron in pondweed (ranging from 216 to $567 \mu \mathrm{g} / \mathrm{g}$ dry weight) was similar to the quantity of boron fed to mallard ducklings exhibiting behavioral and physiological abnormalities. Boron was present at larger concentrations in pondweed from sites receiving irrigation return flow, compared with sites receiving little or no return flow. Cadmium, chromium, and copper were present in some of the biota in elevated concentrations. In a large percentage of fish, concentrations of these elements exceeded criteria used in this study to indicate contamination. The largest and second-largest cadmium concentrations were in carp and perch samples, respectively, collected from Billy Clapp Lake. In atdition to fish samples, some of the snail samples had elevated cadmium and copper concentrations and pondweed samples had elevated chromium concentrations. Mercury and selenium were not elevated in biological tissues although mercury showed a tendency to biomagnify in tl a food chain.

The reasons for elevated cadmium and chromium concentrations in some of the biota samples are unknown. Cadmium was not detected in water or bottom-sediment samples. Although chromium was present in all the bottom-sediment samples, probably from a natural geologic source, the concentrations were typical for soils in the western United States; in water, the concentrations of chromium were generally less than the reporting limit. Chromium also is not a maj rr component of slag metals discharged into the Columbia River nor is it present in FDR Lake in elevated concentrations. The elevated copper concentrations in the biota are probably related to the use of copper sulfate as an algicide in the canals.

Organochlorine pesticides and re'ated compounds were detected in most of the biologica' samples, but usually in small concentrations. In fish samples collected from some of the wasteways, the concentrations of three pesticides (total chlordane, total DDT, and dieldrin) exceeded NAS/NAE (1973) criteria for the protection of fish health and of fish-eating predators. Fish collected from Lind Coulee Wasteway and Scocteney Reservoir contained the largest mean concentrations of these pesticides. Methoxychlor in CBP fish occurred more frequently and at larger concentrations than in a nationwide monitoring study.

Concentrations of total DDT in carp and perch showed little change over the past 15 years. This lack of change is contrary to the significant decline in concentrations of DDT compounds observed in nationwide monitoring programs. Chlordane, detected only infrequently during past years, was detected in abo't 70 percent of the 1992 fish samples. In addition, chlordane concentrations observed in several fish samples were about twice the historical maximum concentration of $0.07 \mu \mathrm{g} / \mathrm{g}$. However, 
changes in laboratory methods and some differences in sample collection sites limit the accuracy in comparing these data sets over time.

Other types of biological assessments used in this study indicated few or no environmental impacts or adverse effects to CBP biota. Surface water was not toxic to Daphnia magna or to the bacteria used in the Microtox toxicity test. Sediment bioassays showed moderate toxicity to Chironomus tentans at 9 of 21 sites. Some of the samples causing toxicity also had some of the largest concentrations of arsenic and methoxychlor in the bottomsediment samples. External lesions in fish were observed only infrequently and mostly in carp and bullhead. No abnormalities in bird embryos were observed and eggshell thicknesses of mallard and grebe eggs were similar to those of the pre-DDT era.

In general, the reconnaissance investigation did not find adverse effects on biota that could be attributed to trace-element concentrations in irrigation drainage. Unlike other NIWQP studies, the hazards to biota in the CBP are reduced by the large volume of imported dilute Columbia River water. However, boron, a trace element commonly elevated in irrigation drainage, was present in aquatic plants at concentrations that might affect waterfowl feeding on these plants. Also, arsenic was present in juvenile coots in concentrations similar to those in mallard ducklings exhibiting abnormalities after being fed an arsenic-supplemented diet during laboratory studies.

\section{SELECTED REFERENCES}

Anderson, R.V., 1977, Concentration of cadmium, copper, lead, and zinc in thirty-five genera of freshwater macroinvertebrates from the Fox River, Illinois and Wisconsin: Bulletin of Environmental Contamination and Toxicolology, v. 18, no. 3, p. 345-349.

Bain, R.C., Jr., 1990, Moses Lake clean lake project irrigation water management, final report: Ellensburg, Washington, Prepared for Moses Lake Irrigation and Rehabilitation District, Washington State Department of Ecology and U.S. Environmental Protection Agency, misc. pag.
Barnes, D.G., Kutz, F.W., and Bottimore, D.P., 1989, Update of toxicity equivalency fretors (TEFs) for estimating risks associated with exposures to mixtures of chlorinated dibenzo-p-dioxins and dibenzofurans (CDDs/CDFs): U.S. Environmental Protection Agency, Risk Assessment Forum, unpaginated.

Bauer, H.H., and Vaccaro, J.J., 1990, Estimates of ground-water recharge to the Co' umbia Plateau Regional Aquifer system, Washiาgton, Oregon, and Idaho, for predevelopment and current land-use conditions: U.S. Geological Survey WaterResources Investigations Report 88-4108, 37 p., 2 plates.

Bauer, H.H., Vaccaro, J.J., and Lane, R.C., 1985, Ground-water levels in the Colunbia River Basalt Group and the overlying materia's, spring 1983, southeastern Washington State: U.S. Geological Survey Water-Resources Investigations Report 84-4360, 4 plates.

Bellin, J.S., and Barnes, D.G., 1987, I 7 terim procedures for estimating risks associated with exposures to mixtures of chlorinated dibenzo-n-dioxins and dibenzofurans (CDDs/CDFs): U.S. Environmental Protection Agency, Risk Assessment Forum, EPA-625/3-87/012, 27 p.

Big Bend Economic Development Co'rncil, 1991, Economic impact and environmental assessment of the decline of fishing, Moses Lake and Potholes Reservoir: Big Bend Economic Development Council, Washington, unpaged.

Block, E.K., 1993, Aquatic biota with in the central Columbia Plateau NAWQA stud' unit--a review of existing information: Moses Lake, Washington, U.S. Fish and Wildlife Service, 92 p.

Blus, L.J., and Henny, C.J., 1985, The effects of heptachlor and lindane on birds, Columbia Basin, Oregon and Washington, 1976-1981: Science of the Total Environment, v. 46, p. $73-\varepsilon 1$. 
Boellstorff, D.E., Ohlendorf, H.M., Anderson, D.W., O'Neill, E.J., Keith, J.O., and Prouty, R.M., 1985, Organochlorine chemical residues in white pelicans and western grebes from the Klamath Basin, California: Archives of Environmental Contamination and Toxicology, v. 14, p. 485-493.

Bortleson, G.C., and Cox, S.E., 1986, Occurrence of dissolved sodium in ground waters in basalts underlying the Columbia Plateau, Washington: U.S. Geological Survey Water-Resources Investigation Report 85-4005, 24 p., 5 plates.

British Columbia Ministry of Environment, 1990, Analyses of preliminary results of dioxin-furan survey of Columbia River fishes: Province of British Columbia, Ministry of Environment, Toxicology Unit, Environmental Protection Division draft no. 3.0, unpaged.

Burton, G.A., Jr., 1992, Assessing contaminated aquatic sediments: ES\&T Series, Environmental Science and Technology, v. 26, no. 10, p. 1,862-1,875.

Caldwell, P.J., and Snart, A.E., 1974, A photographic index for aging mallard embryos: Journal of Wildlife Management, v. 38, no. 2, p. 298-301.

Camardese, M.B., Hoffman, D.J., LeCaptain, L.J., and Pendleton, G.W., 1990, Effects of arsenate on growth and physiology in mallard ducklings: Environmental Toxicology and Chemistry, v. 9, p. 785-795.

Charnetski, W.A., 1976, Organochlorine insecticide residues in ducklings and their dilution by growth: Bulletin of Environmental Contamination and Toxicology, v. 16, p. 138-144.

CRC Press, 1975, Handbook of chemistry and physics, 56 ${ }^{\text {th }}$ Edition, 1975-1976: Cleveland, Ohio, CRC Press, misc. pag.

Davis, D.A., 1993, Washington State pesticide monitoring program--reconnaissance sampling of surface waters (1992): Washington State Department of Ecology, Toxics, Compliance, and Ground-Water Investigations Sections, $38 \mathrm{p}$.
Drost, B.W., Schurr, K.M., Ruppert, G.P., and Cox, S.E., 1989, Well data, surface-water discharges, and nitrate concentrations, February 1986-September 1987, in parts of the Pasco Basin, Washington: U.S. Geological Survey Open-File Report 89-38, 132 p.

Drost, B.W., and Whiteman, K.J., 1986, Surficial geology, structure, and thickness of selected geohydrologic units in the Columbia Plateau, V/ashington: U.S. Geological Survey Water-Resou+ces Investigations Report 84-4326, 11 plates.

Drost, B.W., Whiteman, K.J., and Gonthier, J.B., 1990 , Geologic framework of the Colcmbia Plateau Aquifer System, Washington, Oregon, and Idaho: U.S. Geological Survey Water-Resources Investigations Report $87-4238,10$ p., 10 plates.

Dye, W.B., and O'Hara, J.L., 1959, Molybdosis: Nevada Agricultural Experimental Staticn Bulletin 208, 32 p.

Edwards, T.K., and Glysson, G.D., 1988, Field methods for measurement of fluvial sedinent: U.S. Geological Survey Open-File Report 86-531, 118 p.

Eisler, Ronald, 1985a, Selenium haza-ds to fish, wildlife, and invertebrates--a synoptic review: Washington, D.C., U.S. Fish and Wildlife Service, Biological Report 85(1.5), $57 \mathrm{p}$.

1985b, Cadmium hazards to fish, wildlife, and invertebrates--a synoptic review: Washington, D.C., U.S. Fish and Wildlife Service, F ological Report no. 85 (1.2), 46 p.

1985c, Chlordane hazards to fish, wildlife, and invertebrates--a synoptic review: Washington, D.C., U.S. Fish and Wildlife Service, F ological Report no. 85 (1.21), 49 p.

1986, Chromium hazards to fish, wildlife, and invertebrates--a synoptic review: Washington, D.C., U.S. Fish and Wildlife Service, F ological Report no. 85 (1.6), $60 \mathrm{p}$.

1988, Arsenic hazards to fish, vildlife, and invertebrates--a synoptic review: Washington, D.C., U.S. Fish and Wildlife Service, Piological Report no. 85 (1.12), 92 p. 
1990, Boron hazards to fish, wildlife, and invertebrates--a synoptic review: Washington, D.C., U.S. Fish and Wildlife Service, Biological Report no. 85 (1.20), $32 \mathrm{p}$.

Environment Canada, 1979, Water quality sourcebook--a guide to water quality parameters: Environment Canada, Water-Quality Branch, unpaged.

Feltz, H.R., Engberg, R.A., and Sylvester, M.A., 1990, Investigations of water quality, bottom sediment, and biota associated with irrigation drainage in the western United States, in The Hydrological Basis of Water Resources Management, Proceedings of the Beijing Symposium, October 1990: International Association of Hydrological Sciences Publication no. 197 , p. $119-129$

Fimreite, N., 1979, Accumulation and effects of mercury on birds, in Nriagu, J.O., ed., The biogeochemistry of mercury in the environment: New York, Elsevier/ North Holland Biomedical Press, p. 601-627.

Fimreite, N., and Bjerk, J.E., 1983, Residues of DDE and PCBs in Norwegian seabirds' fledglings, compared to those in their eggs: Astarte, v. 12, p. 49-51.

Fishman, M.J., and Friedman, L.C., 1989, Methods for determination of inorganic substances in water and fluvial sediments: U.S. Geological Survey Techniques of Water-Resources Investigations, Third edition, Book 5, chap. A1, 545 p.

Foster, J.H., Tillett, W.E., Myers, W.L., and Hoag, J.C., 1984, Columbia Basin wildlife/irrigation development study: Denver, Colorado, U.S. Bureau of Reclamation, Engineering and Research Center, $237 \mathrm{p}$.

Friant, S.L., 1979, Trace metal concentrations in selected biological, sediment, and water column samples in a northern New England river: Water, Air, and Soil Pollution, v. 11, p. 455-465.

Gardner, D.R., and Bailey, J.R., 1975, Methoxychlor--its effects on environmental quality: Ottawa, Canada, National Research Council of Canada, Publication no. NRCC 14102, 164 p.
Hearn, P.P., Steinkampf, W.C., Bortles on, G.C., and Drost, B.W., 1985, Geochemical contro's on dissolved sodium in basalt aquifers of the Columbia Plateau, Washington: U.S. Geological Survey WaterResources Investigations Report 84-4304, 38 p., 1 plate.

Heinz, G.H., 1979, Methylmercury--reproductive and behavioral effects on three generations of mallard ducks: Journal of Wildlife Manazement, v. 43, no. 2, p. $394-401$.

Helsel, D.R., and Cohn, T.A., 1988, Estimation of descriptive statistics for multiply censored water quality data: Water Resources Research, v. 24, no. 12 , p. $1,997-2,004$.

Hem, J.D., 1989, Study and interpretation of the chemical characteristics of natural water ( rd ed.): U.S. Geological Survey Water-Supply Paper 2254, 263 p.

Henny, C.J., Blus, L.J., Krynitsky, A.J., and Bunck, C.M., 1984, Current impact of DDE on black-crowned night-herons in the intermountair west: Journal of Wildlife Management, v. 48, no. 1, p. 1-13.

Henry, M.G., and Jaschke, D.P., no date, Bulk sediment Chironomus tentans toxicity test analysis of selected sites within the Columbia Basin Irrigation Project, final report: University of Minnesota, Minnesota Cooperative Fish and Wildlife Research Unit, 12 p.

Hoffman, D.J., Camardese, M.B., LeCaptain, L.J., and Pendleton, G.W., 1990, Effects of boron on growth and physiology in mallard ducklings: Environmental Toxicology and Chemistry, v. 9, p. 335-346.

Hopkins, B.S., Clark, D.K., Schlender, T.W., and Stinson, Margaret, 1985, Basic Water Monitoring Program-fish tissue and sediment sampling for 1984: Olympia, Washington, Washington Department of Ecology, Water Quality Investigations Section, $43 \mathrm{p}$.

Johnson, Arthur, and Norton, Dale, 1930, 1989 Lakes and Reservoir Water Quality Assessnent Program-survey of chemical contaminants in ten Washington lakes: Olympia, Washington, Washington Department of Ecology, Toxics Investigations and Ground Water Monitoring Section, $30 \mathrm{p}$. 
Johnson, Arthur, Norton, Dale, Yake, William, and Twiss, Steven, 1990, Transboundary metal pollution of the Columbia River (Franklin D. Roosevelt Lake): Bulletin of Environmental Contamination and Toxicology, v. 45, p. 703-710.

Johnson, Arthur, Serdar, David, and Magoon, Stuart, 1991b, Polychlorinated dioxins and furans in Lake Roosevelt (Columbia River) sportfish, 1990: Olympia, Washington, Washington Department of Ecology, Toxics Investigations and Ground Water Monitoring Section, Publication No. 91-4, 56 p.

Johnson, Arthur, Serdar, David, and Norton, Dale, 1991a, Spatial trends in TCDD/TCDF concentrations in sediment and bottom fish collected in Lake Roosevelt (Columbia River): Olympia, Washington, Washington Department of Ecology, Toxics Investigations and Ground Water Monitoring Section, Publication No. 91-29, 39 p.

Knapton, J.R., Jones, W.E., and Sutphin, J.W., 1988, Reconnaissance investigation of water quality, bottom sediment, and biota associated with irrigation drainage in the Sun River area, west-central Montana, 1986-87: U.S. Geological Survey Water-Resources Investigations Report 87-4244, $78 \mathrm{p}$.

Lemly, A.D., Finger, S.E., and Nelson, M.K., 1993, Sources and impacts of irrigation drainwater contaminants in arid wetlands: Environmental Toxicology and Chemistry, v. 12, p. 2,265-2,279.

Lemly, A.D., and Smith, G.J., 1987, Aquatic cycling of selenium--implications for fish and wildlife: Washington, D.C., U.S. Fish and Wildlife Service Leaflet no. $12,10 \mathrm{p}$.

Lowe, T.P., May, T.W., Brumbaugh, W.G., and Kane, D.A., 1985, National Contaminant Biomonitoring Program--concentrations of seven elements in freshwater fish, 1978-1981: Archives of Environmental Contamination and Toxicology, v. 14, p. 363-388.

Magna Corporation, 1984, Dissipation of Magnacide H herbicide: Bakersfield, Calif., Magna Corporation, product data bulletin, $1 \mathrm{p}$.
May, T.W., and McKinney, G.L., 1981, Cadmium, lead, mercury, arsenic, and selenium concentrations in freshwater fish, 1976-77--National Pesticide Monitoring Program: Pesticide Monitoring Journal, v. 15 , p. $14-38$.

Microbics Corporation, 1992, Microtox manual--a toxicity testing handbook: Carlsbad, California, Microbics Corporation, misc. pag.

Moore, J.W., and Ramamoorthy, S., 19?.4, Heavy metals in natural waters--applied monitorirg and impact assessment: New York, Springer-Verlag, 168 p.

National Academy of Sciences, 1976, Selenium: Washington, D.C., National Academy of Sciences, $203 \mathrm{p}$.

National Academy of Sciences and National Academy of Engineering, 1973, Water-quality criteria, 1972: Washington, D.C., U.S. Environmental Protection Agency, Ecological Research Series, EPA-R3-73-033-March 1973, 594 p.

National Oceanic and Atmospheric Administration, 1982, Monthly normals of temperature, precipitation, and heating and cooling degree days 1951-80: Ashville, North Carolina, National Oceanic and Atmospheric Administration, Environmental $\mathrm{L}$ ata and Information Service, National Climatic Center, Climatography of the United Stat is no. 81, misc. pag.

National Research Council Subcommittee on Mineral Toxicity in Animals, 1980, Boror, in Nutrient and Toxic Substances in Water for Dcmestic Animals: Washington, D.C., National Academy Press, p. 71-83.

Olson, J.R., Bellin, J.S., and Barnes, D.G., 1989, Reexamination of data used for e tablishing toxicity equivalence factors (TEFs) for chlorinated dibenzo- $p$-dioxins and dibenzofurans (CDDs/CDFs): Chemosphere, v. 18, p. 371-381.

Patuxent Wildlife Research Center, 19?7, Effects of irrigation drain water contaminants on wildlife: Laurel, Maryland, Patuxent Wild ife Research Center, U.S. Fish and Wildlife Service, Annual Report Fiscal Year 1986, 24 p. 
Pritt, Jeffrey, and Jones, B.E., eds., 1989, National water-quality laboratory services catalog: U.S. Geological Survey Open-File Report 89-386, misc. pag.

Rinella, J.F., McKenzie, S.W., and Fuhrer, G.J., 1992, Surface-water-quality assessment of the Yakima River Basin, Washington--analysis of available water-quality data through 1985 water year: U.S. Geological Survey Open-File Report 91-453, 244 p.

San Joaquin Valley Drainage Program, 1990, Fish and wildlife resources and agricultural drainage in the San Joaquin Valley, California: San Joaquin Valley Drainage Program, misc. pag.

SAS Institute, Inc., 1988, SAS/STAT user's guide, release 6.03 edition: Cary, North Carolina, SAS Institute, Inc., $1,028 \mathrm{p}$.

Schmitt, C.J., and Brumbaugh, W.G., 1990, National Contaminant Biomonitoring Program-concentrations of arsenic, cadmium, copper, lead, mercury, selenium, and zinc in U.S. freshwater fish, 1976-1984: Archives of Environmental Contamination and Toxicology, v. 19, p. 731-747.

Schmitt, C.J., Zajicek, J.L., and Peterman, P.H., 1990, National Contaminant Biomonitoring Program-residues of organochlorine chemicals in U.S. freshwater fish, 1976-1984: Archives of Environmental Contamination and Toxicology, v. 19, p. $748-781$.

Schmitt, C.J., Zajicek, J.L., and Ribick, M.A., 1985, National Pesticide Monitoring Program--residues of organochlorine chemicals in freshwater fish, 1980-81: Archives of Environmental Contamination and Toxicology, v. 14, p. 225-260.

Severson, R.C., Wilson, S.A., and McNeal, J.M., 1987, Analyses of bottom sediment collected at nine areas in the Western United States for the Department of Interior irrigation drainage task group: U.S. Geological Survey Open-File Report 87-490, 24 p.

Shacklette, H.T., and Boerngen, J.G., 1984, Element concentrations in soils and other surficial materials of the conterminous United States: U.S. Geological Survey Professional Paper 1270, 105 p.
Skorupa, J.P., and Ohlendorf, H.M. 1991, Contaminants in drainage water and avian risk thresholds, in Dinar, Ariel, and Zilberman, David, eds., The economics and management of water and drainage in agriculture: Boston, Massach isetts, Kluwer Academic Publishers, p. 345-368.

Smith, A.L., 1987, Levels of metals and metallothionein in fish of the Columbia River near the international border: Province of British Columbia, Ministry of Environment, Lands, and Parks, Water Management Branch, 133 p.

Smith, G.J., and Anders, V.P., 1989, Toxic effects of boron on mallard reproduction: Environmental Toxicology and Chemistry, v. 8, p. 943-95?.

Smith, J.A., Witkowski, P.J., and Fr'sillo, T.V., 1988, Manmade organic compounds in the surface waters of the United Sates--a review of current understanding: U.S. Geological Survey Circular $1007,92 \mathrm{p}$.

Sorenson, S.K., and Schwarzbach, S.E., 1991, Reconnaissance investigation of water quality, bottom sediment, and biota associated with irrigation drainage in the Klamath Basin, California and Oregon, 1988-89: U.S. Geolo Țical Survey Water-Resources Investigatiors Report 90-4203, $64 \mathrm{p}$.

Spehar, R.L., Anderson, R.L., and Fiandt, J.T., 1978, Toxicity and bioaccumulation of cadmium and lead in aquatic invertebrates: Environmental Pollution, v. 15, p. $195-208$.

Spehar, R.L., Fiandt, J.T., Anderson, R.L., and DeFoe, D.L., 1980, Comparative toxicity of arsenic compounds and their accumulation in invertebrates and fish: Archives of Environ nental Contamination and Toxicology, v. 9, p. 53-63.

Steinkampf, W.C., 1989, Water-qua'ity characteristics of the Columbia Plateau regional aquifer system in parts of Washington, Oregon, and Idaho: U.S. Geological Survey Water-Resources Investigations Report 87-4242, 37 p. 
Stephens, D.W., Waddell, Bruce, and Miller, J.B., 1988, Reconnaissance investigation of water quality, bottom sediment, and biota associated with irrigation drainage in the middle Green River basin, Utah, 1986-87: U.S. Geological Survey Water-Resources Investigations Report 88-4011, 70 p.

Sylvester, M.A., Deason, J.P., Feltz, H.R., and Engberg, R.A., 1988, Preliminary results of the Department of Interior's irrigation drainage studies, in Proceedings of Planning Now For Irrigation and Drainage, Lincoln, Nebraska, July 1988, Irrigation Division, American Society of Civil Engineers, p. 665-677.

Tanaka, H.H., Hansen, A.J., Jr., and Skrivan, J.A., 1974, Digital model study of ground-water hydrology, Columbia River Basin Irrigation Project area, Washington: Olympia, Washington, Washington Department of Ecology, Water Supply Bulletin 40, $60 \mathrm{p}$.

Toxscan, Inc., 1991, Toxicity testing of fresh water collected for the Columbia Basin Irrigation Project: Watsonville, California, prepared for U.S. Fish and Wildlife Service, Toxscan, Inc., 9 p.

1992a, Toxicity testing of fresh water collected for the Columbia Basin Irrigation Project: Watsonville, California, prepared for U.S. Fish and Wildlife Service, Toxscan, Inc., $11 \mathrm{p}$.

$1992 \mathrm{~b}$, Toxicity testing of fresh water collected for the Columbia Basin Irrigation Project: Watsonville, California, prepared for U.S. Fish and Wildlife Service, Toxscan, Inc., 13 p.

Turney, G.L., 1986, Quality of ground water in the Columbia Basin, Washington, 1983: U.S. Geological Survey Water-Resources Investigations Report 85-4320, 172 p., 5 plates.

U.S. Bureau of Reclamation, 1976, Final environmental impact statement, Columbia Basin Project, Washington: U.S. Bureau of Reclamation, Department of the Interior, INTFES-76-8, v. 1, misc. pag.

1982, Columbia Basin Project water quality: U.S. Bureau of Reclamation, July 1982, 49 p.
1989, Draft environmental impact statement, continued development of the Columbia Basin Project: Boise, Idaho, U.S. Bureau of Reclamation, Pacific Northwest Region, Department of the Interior, DES 89-A, misc. pag.

U.S. Department of Commerce, 1982, 1982 Census of Agriculture: Washington, D.C., E ureau of the Census, v. 1, part 47, Washington State, misc. pag.

U.S. Environmental Protection Agency. 1976, Quality criteria for water: Washington, D.C., U.S. Environmental Protection Agency: 256 p.

1985 , Methods for measuring the acute toxicity of effluents to freshwater and marine organisms: Washington, D.C., U.S. Environmental Protection Agency, EPA/600/4-85/013, 216 p.

1986, Quality criteria for Water - 1986:

Washington, D.C., U.S. Environmental Protection Agency, EPA 440/5-86-001, May 1, 1986, unpaged.

1987, Ambient water quality crit sria for selenium 1987: Washington, D.C., U.S. Environmental Protection Agency, EPA 440/5-87-006, September, 1987, $121 \mathrm{p}$.

1991a, National primary drinking water regulations-synthetic organic chemicals and inorganic chemicals, final rule, Ja uuary 30, 1991: Washington, D.C., Federal Regist $3 x$, v. 56, no. 20, p. 3,526-3,530.

1991b, Radionuclides in drinking water, factsheet; national primary drinking water regulations for radionuclides, proposed rule, June 1991:

Washington, D.C., U.S. Environmental Protection Agency, Office of Ground Water and Drinking Water, $12 \mathrm{p}$.

1992a, Drinking water regulatiors and health advisories, November 1992: Offi :e of Water, Washington, D.C., U.S. Environmental Protection Agency, Office of Water, $11 \mathrm{p}$.

1992b, National study of chemical residues in fish: Washington, D.C., U.S. Environmental Protection Agency, Office of Science and Te'hnology, misc. pag. 
U.S. Fish and Wildlife Service, 1992, 1991 Annual narrative report: Othello, Washington, U.S. Fish and Wildlife Service, Columbia National Wildlife Refuge, misc. pag.

U.S. Food and Drug Administration, 1985, Action levels for poisonous or deleterious substances in human food and animal feed: Washington, D.C., U.S. Food and Drug Administration, Center for Food Safety and Applied Nutrition, Industry Programs Branch, misc. pag.

Walters, K.L., and Grolier, M.J., 1960, Geology and ground-water resources of the Columbia Basin Project area, Washington: Olympia, Washington, Washington Division of Water Resources, Water Supply Bulletin 8, v. 1, 542 p.

Ward, J.R., and Harr, C.A., eds., 1990, Methods for collection and processing of surface-water and bed-material samples for physical and chemical analyses: U.S. Geological Survey Open-File Report 90-140, $71 \mathrm{p}$.

Washington State Department of Social and Health Services, 1974 [1975], Pesticide residues in the Columbia Basin Irrigation Project, January 1 through December 31, 1974: Wenatchee, Washington, Washington State Department of Social and Health Services, Health Services Division, Community Pesticide Study Project, Contract No. 14-06-100-8050, January 28, 1974 [1975], 14 p.

1976, Pesticide monitoring program--1975 annual report, U.S. Bureau of Reclamation Columbia Basin Project: Wenatchee, Washington, Washington State Department of Social and Health Services, Health Services Division, Regional Pesticide and Chemical Laboratory, January 1976, 27 p.
1977, Pesticide monitoring program--1976 annual report, U.S. Bureau of Reclamation Columbia Basin Project: Wenatchee, Washington, Washington State Department of Social and Heal 'h Services, Health Services Division, Regional Pesticide and Chemical Laboratory, February 1977, 28 p.

1978, Pesticide monitoring program--1977 annual report, U.S. Bureau of Reclamation Columbia Basin Project: Wenatchee, Washington, Washington State Department of Social and Heal 'h Services, Health Services Division, Regional Pesticide and Chemical Laboratory, March 1978, 16 p.

1979, Pesticide monitoring program--1978 annual report, U.S. Bureau of Reclametion Columbia Basin Project: Wenatchee, Washington, Washington State Department of Social and Heal $h$ Services, Health Services Division, Regional Pe ticide and Chemical Laboratory, $13 \mathrm{p}$.

Welch, E.B., Jones, C.A., and Barbiero, R.P., 1990, Moses Lake quality--results of dilution, sewage diversion and BMP's--1977 through 1988: University of Washington, Department of Civil Engineering, Water Resources Technical Report 118, July 1989, 65 p.

Wershaw, R.L., Fishman, M.J., Grabלe, R.R., and Lowe, L.E., 1987, Methods for the detrmination of organic substances in water and fluvial sediments: U.S. Geological Survey Techniques of Water-Resources Investigations, Book 5, chap. A3, $80 \mathrm{p}$.

Wier, C.F., and Walter, W.M., 1976, Toxicity of cadmium in the freshwater snail Physa gyrina: Journal of Environmental Quality, v. 5, p. 359-362. 
DATA TABLES 
Table 25.--Field measurements and results of analyses for inorganic constituents in filtered water samples from the Columbia Basin Project, November 1991, March 1992, and July 1992

$\left[\mathrm{mg} / \mathrm{L}\right.$, milligrams per liter; $\mu \mathrm{g} / \mathrm{L}$, micrograms per liter; $\mu \mathrm{S} / \mathrm{cm}$, microsiemens per centimeter at 25 degrees Celsius; CaCO ${ }_{3}$, calcium carbonate; $\mathrm{CO}_{3}$, carbonate; $\mathrm{HCO}_{3}$, bicarbonate; <, less than; --, no data]

\begin{tabular}{|c|c|c|c|c|c|c|c|c|c|c|c|}
\hline $\begin{array}{l}\text { Map } \\
\text { identi- } \\
\text { fier } \\
\text { (fig. 9) }\end{array}$ & Station name & Date & $\begin{array}{l}\text { Dis- } \\
\text { charge } \\
\text { (cubic } \\
\text { feet per } \\
\text { second) }\end{array}$ & $\begin{array}{l}\text { Spe- } \\
\text { cific } \\
\text { con- } \\
\text { duct- } \\
\text { ance } \\
(\mu S / c m)\end{array}$ & $\begin{array}{l}\text { pH } \\
\text { (stand- } \\
\text { ard } \\
\text { units) }\end{array}$ & $\begin{array}{l}\text { Temper- } \\
\text { ature } \\
\text { (degrees } \\
\text { Celsius) }\end{array}$ & $\begin{array}{l}\text { Trans- } \\
\text { parency, } \\
\text { Secchi } \\
\text { disk } \\
\text { (feet) }\end{array}$ & $\begin{array}{l}\text { Baro- } \\
\text { metric } \\
\text { pres- } \\
\text { surc } \\
\text { (milli- } \\
\text { meters, } \\
\text { mercury) }\end{array}$ & $\begin{array}{l}\text { Dis- } \\
\text { solved } \\
\text { oxygen } \\
\text { (mg/L) }\end{array}$ & $\begin{array}{l}\text { Hard- } \\
\text { ness } \\
\text { (mg/L } \\
\text { as } \\
\mathrm{CaCO}_{3} \text { ) }\end{array}$ & $\begin{array}{l}\text { Cal- } \\
\text { cium } \\
(\mathrm{mg} / \mathrm{L})\end{array}$ \\
\hline \multirow[t]{3}{*}{$\mathrm{BCL}$} & \multirow[t]{3}{*}{ Billy Clapp Lake } & $11 / 18 / 91$ & -- & 140 & 7.9 & 9.0 & 10.0 & -- & $9.8-9.8$ & 62 & 18 \\
\hline & & $03 / 02 / 92$ & - & 133 & 8.1 & 4.0 & 23.0 & 731 & ${ }^{\prime \prime} 10.9-11.3$ & 65 & 19 \\
\hline & & $07 / 13 / 92$ & -- & 136 & 8.2 & 15.0 & 18.0 & 720 & $2.2-8.3$ & 66 & 19 \\
\hline \multirow[t]{3}{*}{ RFC } & \multirow[t]{3}{*}{ Rocky Ford Creek } & $11 / 18 / 91$ & 62 & 385 & 7.8 & 8.5 & -- & -- & 7.8 & 140 & 34 \\
\hline & & $03 / 02 / 92$ & 37 & 381 & 8.0 & 10.5 & - & 736 & 8.8 & 140 & 32 \\
\hline & & $07 / 13 / 92$ & 38 & 378 & 8.3 & 23.0 & - & 731 & 13.5 & 140 & 33 \\
\hline $\mathrm{CCU}$ & Upper Crab Creek & $07 / 14 / 92$ & 54 & 485 & 8.3 & 17.5 & - & 736 & 12.5 & 240 & 59 \\
\hline \multirow[t]{3}{*}{ MLR } & \multirow{3}{*}{$\begin{array}{l}\text { Moses Lake, } \\
\text { Rocky Ford arm }\end{array}$} & $11 / 18 / 91$ & $\cdots$ & 312 & 9.0 & 6.0 & 5.0 & -- & $11.3-13.0$ & 120 & 29 \\
\hline & & $03 / 02 / 92$ & -- & 314 & 9.2 & 6.5 & 3.5 & 737 & $10.7-17.9$ & 120 & 25 \\
\hline & & $07 / 14 / 92$ & -- & 241 & 9.0 & 22.5 & 3.5 & 734 & $4.2-9.4$ & 95 & 22 \\
\hline MLP & $\begin{array}{l}\text { Moses Lake, } \\
\text { Parker Hom arm }\end{array}$ & $07 / 14 / 92$ & - & 290 & 8.9 & 22.5 & 4.0 & 734 & $" 10.9-11.4$ & 130 & 30 \\
\hline \multirow[t]{3}{*}{ MLS } & \multirow{3}{*}{$\begin{array}{l}\text { Moses Lake, } \\
\text { south end }\end{array}$} & $11 / 19 / 91$ & -- & 287 & 8.9 & 6.0 & 6.0 & $\cdots$ & $\bullet 11.7-11.8$ & 120 & 29 \\
\hline & & 03/03/92 & - & 363 & 9.0 & 6.5 & 5.0 & 734 & ${ }^{A} 13.8-14.3$ & 140 & 30 \\
\hline & & $07 / 14 / 92$ & -- & 238 & 8.8 & 22.0 & 4.3 & 734 & $1.2-11.9$ & 98 & 24 \\
\hline \multirow[t]{3}{*}{ PRW } & \multirow{3}{*}{$\begin{array}{l}\text { Potholes Reservoir, } \\
\text { west arm }\end{array}$} & $11 / 19 / 91$ & -- & 552 & 8.6 & 5.5 & 7.0 & -- & $13.2-13.3$ & 220 & 42 \\
\hline & & $03 / 03 / 92$ & -- & 383 & 8.6 & 6.5 & 13.0 & -- & $12.6-13.1$ & 150 & 31 \\
\hline & & $07 / 15 / 92$ & - & 599 & 8.2 & 16.0 & 7.0 & 736 & $7.8-12.6$ & 240 & 49 \\
\hline PRE & $\begin{array}{l}\text { Potholes Reservoir, } \\
\text { east arm }\end{array}$ & $07 / 15 / 92$ & - & 294 & 8.8 & 23.0 & 3.0 & 736 & $9.5-11.4$ & 120 & 29 \\
\hline \multirow[t]{3}{*}{ Ww } & Winchester & $11 / 18 / 91$ & 132 & 496 & 8.3 & 5.5 & -- & -. & 12.0 & 190 & 50 \\
\hline & \multirow[t]{2}{*}{ Wasteway } & $03 / 02 / 92$ & 76 & 504 & 8.6 & 7.5 & - & -. & 12.2 & 190 & 47 \\
\hline & & $07 / 15 / 92$ & 108 & 326 & 8.2 & 23.0 & -- & 738 & 8.3 & 140 & 34 \\
\hline \multirow[t]{3}{*}{ FHW } & \multirow{3}{*}{$\begin{array}{l}\text { Frenchman Hills } \\
\text { Wasteway }\end{array}$} & $11 / 21 / 91$ & 278 & 591 & 8.5 & 6.0 & $\cdots$ & -. & 12.6 & 220 & 47 \\
\hline & & $03 / 03 / 92$ & 157 & 656 & 8.7 & 8.5 & -- & -. & 12.8 & 250 & 49 \\
\hline & & $07 / 15 / 92$ & 566 & 347 & 8.2 & 20.0 & -- & 738 & 9.2 & 140 & 34 \\
\hline \multirow[t]{3}{*}{ LCW } & \multirow{3}{*}{$\begin{array}{l}\text { Lind Coulee } \\
\text { Wasteway }\end{array}$} & $11 / 18 / 91$ & 106 & 614 & 8.4 & 9.5 & -- & -- & 13.4 & 200 & 47 \\
\hline & & $03 / 02 / 92$ & 58 & 640 & 8.4 & 10.0 & - & 735 & 11.6 & 200 & 49 \\
\hline & & $07 / 14 / 92$ & 363 & 301 & 8.1 & 20.0 & -- & 733 & 8.3 & 120 & 31 \\
\hline \multirow[t]{3}{*}{ SL } & \multirow[t]{3}{*}{ Soda Lake } & $11 / 20 / 91$ & - & 366 & 8.1 & 8.5 & 11.0 & .. & $7.2-7.4$ & 140 & 30 \\
\hline & & $03 / 04 / 92$ & - & 380 & 8.6 & 5.0 & 6.5 & 739 & $" 12.6-14.8$ & 140 & 31 \\
\hline & & $07 / 17 / 92$ & - & 310 & 8.5 & 15.5 & 8.0 & $734^{2}<$ & $1-10.8$ & 110 & 24 \\
\hline $\mathrm{CCM}$ & $\begin{array}{l}\text { Lower Crab Creek, } \\
\text { McManamon Road }\end{array}$ & $07 / 15 / 92$ & 72 & 271 & 8.7 & 25.0 & -- & 738 & 8.4 & 100 & 25 \\
\hline LGL & Lower Goose Lake & $07 / 17 / 92$ & - & 307 & 8.0 & 12.5 & 6.2 & $738{ }^{a}<$ & $1-12.6$ & 100 & 25 \\
\hline $\mathrm{SHCb}$ & $\begin{array}{l}\text { Sand Hollow Creek } \\
\text { at mouth }\end{array}$ & $11 / 20 / 91$ & 33 & 693 & 8.6 & 11.0 & -- & -. & 10.6 & 300 & 68 \\
\hline \multirow[t]{2}{*}{ SHCa } & Sand Hollow Creek & $03 / 04 / 92$ & 12 & 689 & 8.8 & 11.0 & - & -- & 12.0 & 300 & 65 \\
\hline & at Road S, SW & $07 / 16 / 92$ & 85 & 387 & 8.4 & 18.0 & - & 739 & 9.5 & 170 & 41 \\
\hline \multirow[t]{3}{*}{ CCB } & Crab Creek near & $11 / 21 / 91$ & 266 & 821 & 8.4 & 6.0 & - & -- & 11.2 & 250 & 51 \\
\hline & Beverly & $03 / 05 / 92$ & - & 831 & 8.6 & 8.5 & -- & 749 & 11.3 & 250 & 50 \\
\hline & & $07 / 16 / 92$ & 268 & 540 & 8.6 & 24.5 & - & 748 & 11.4 & 180 & 39 \\
\hline SMW & $\begin{array}{l}\text { Saddle Mountain } \\
\text { Wosteway }\end{array}$ & $07 / 17 / 92$ & 51 & 377 & 8.7 & 23.0 & -- & 746 & 9.5 & 140 & 29 \\
\hline
\end{tabular}


Table 25.--Field measurements and results of analyses for inorganic constituents in filtered water samples from the Columbia Basin Project, November 1991, March 1992, and July 1992--Continued

\begin{tabular}{|c|c|c|c|c|c|c|c|c|c|c|c|}
\hline $\begin{array}{l}\text { Map } \\
\text { identi- } \\
\text { fier } \\
\text { (fig. 9) }\end{array}$ & Station name & Date & $\begin{array}{l}\text { Dis- } \\
\text { charge } \\
\text { (cubic } \\
\text { feet per } \\
\text { second) }\end{array}$ & $\begin{array}{l}\text { Spe- } \\
\text { cific } \\
\text { con- } \\
\text { duct- } \\
\text { ance } \\
\text { ( } \mu \mathrm{S} / \mathrm{cm})\end{array}$ & $\begin{array}{l}\text { pH } \\
\text { (stand- } \\
\text { and } \\
\text { units) }\end{array}$ & $\begin{array}{l}\text { Temper- } \\
\text { eture } \\
\text { (degrees } \\
\text { Celsius) }\end{array}$ & $\begin{array}{l}\text { Trans- } \\
\text { parency, } \\
\text { Secchi } \\
\text { disk } \\
\text { (feet) }\end{array}$ & $\begin{array}{l}\text { Baro- } \\
\text { metric } \\
\text { pres- } \\
\text { sure } \\
\text { (milli- } \\
\text { meters, } \\
\text { mercury) }\end{array}$ & $\begin{array}{l}\text { Dis- } \\
\text { solved } \\
\text { oxygen } \\
\text { (mg/L) }\end{array}$ & $\begin{array}{l}\text { Hand- } \\
\text { ness } \\
(\mathrm{mg} / \mathrm{L} \\
\left.\mathrm{CaCO}_{3}\right)\end{array}$ & $\begin{array}{l}\text { Cal- } \\
\text { cium } \\
(\mathrm{mg} / \mathrm{L})\end{array}$ \\
\hline \multirow[t]{3}{*}{ ELW } & EL68D Wasteway & $11 / 19 / 91$ & 47 & 733 & 8.6 & 7.5 & - & - & 10.8 & 240 & 43 \\
\hline & & $03 / 04 / 92$ & 13 & 947 & 8.7 & 9.5 & - & 751 & 11.3 & 340 & 81 \\
\hline & & $07 / 14 / 92$ & 230 & 325 & 8.1 & 21.5 & - & 734 & 8.2 & 130 & 27 \\
\hline \multirow[t]{3}{*}{ WBWa } & Wahluke Branch & $11 / 19 / 91$ & 4.4 & 959 & 8.3 & 8.0 & - & -- & 10.8 & 320 & 67 \\
\hline & 10A Wasteway & $03 / 04 / 92$ & 2.5 & 982 & 8.4 & 10.5 & - & - & 10.7 & 320 & 64 \\
\hline & & $07 / 17 / 92$ & 17 & 509 & 8.4 & 23.0 & - & 746 & 8.6 & 180 & 38 \\
\hline \multirow[t]{3}{*}{ PEW } & PE16.4 Wasteway & $11 / 20 / 91$ & 142 & 573 & 8.6 & 7.5 & - & - & 12.9 & 210 & 45 \\
\hline & & $03 / 03 / 92$ & 26 & 776 & 8.5 & 8.0 & - & - & 11.9 & 260 & 45 \\
\hline & & $07 / 16 / 92$ & 91 & 487 & 8.6 & 24.0 & - & 748 & 8.7 & 180 & 39 \\
\hline \multirow[t]{4}{*}{ ECW } & Esquatzel Coulee & $11 / 20 / 91$ & 102 & 599 & 8.4 & 9.0 & - & - & 11.7 & 220 & 50 \\
\hline & Wasteway & 03/03/92 & 27 & 765 & 8.4 & 9.5 & - & 746 & 11.3 & 280 & 64 \\
\hline & & $07 / 16 / 92$ & 100 & 420 & 8.2 & 19.5 & - & 750 & 9.0 & 160 & 36 \\
\hline & \multicolumn{11}{|c|}{ Duplicate Samolea } \\
\hline $\mathrm{SHCb}$ & $\begin{array}{l}\text { Sand Hollow Creek } \\
\text { at mouth }\end{array}$ & $11 / 20191$ & 37 & 693 & 8.6 & 11.0 & - & - & 10.6 & 300 & 67 \\
\hline PRW & $\begin{array}{l}\text { Potholes Reservoir, } \\
\text { west arm }\end{array}$ & $03 / 03 / 92$ & -- & 383 & 8.6 & 6.5 & - & - & $12.6-13.1$ & 150 & 31 \\
\hline PRE & $\begin{array}{l}\text { Potholes Reservoir, } \\
\text { east arm }\end{array}$ & $07 / 15 / 92$ & -- & 294 & 8.9 & 23.0 & - & 736 & $9.5-11.4$ & 120 & 30 \\
\hline WW & $\begin{array}{l}\text { Winchester } \\
\text { Wasteway }\end{array}$ & $07 / 15 / 92$ & 108 & 326 & 8.4 & 24.5 & - & 738 & 8.4 & 140 & 34 \\
\hline
\end{tabular}


Table 25.--Field measurements and results of analyses for inorganic constituents in filtered water simples from the Columbia Basin Project, November 1991, March 1992, and July 1992--Continued

\begin{tabular}{|c|c|c|c|c|c|c|c|c|c|c|c|c|}
\hline $\begin{array}{l}\text { Map } \\
\text { identi- } \\
\text { fier } \\
\text { (fig. 9) }\end{array}$ & Station name & Date & $\begin{array}{l}\text { Mag- } \\
\text { nesium } \\
\text { (mg/L) }\end{array}$ & $\begin{array}{l}\text { Sodium } \\
\text { (mg/L) }\end{array}$ & $\begin{array}{l}\text { Per- } \\
\text { cent } \\
\text { sod- } \\
\text { ium }\end{array}$ & $\begin{array}{l}\text { Sodium } \\
\text { ad- } \\
\text { sorp- } \\
\text { tion } \\
\text { ratio }\end{array}$ & $\begin{array}{l}\text { Potas- } \\
\text { sium } \\
\text { (mg/L) }\end{array}$ & $\begin{array}{l}\text { Bicar- } \\
\text { bonate } \\
(\mathrm{mg} / \mathrm{L} \\
\mathrm{as} \\
\left.\mathrm{HCO}_{3}\right)\end{array}$ & $\begin{array}{l}\text { Car- } \\
\text { bonate } \\
\text { (mg/L } \\
28 \\
\left.\mathrm{CO}_{3}\right)\end{array}$ & $\begin{array}{l}\text { Alka- } \\
\text { linity } \\
\text { (mg/L } \\
\text { as } \\
\mathrm{CaCO}_{3} \text { ) }\end{array}$ & $\begin{array}{l}\text { Sul- } \\
\text { fote } \\
\text { (mg/L) }\end{array}$ & $\begin{array}{l}\text { Chlo- } \\
\text { ride } \\
\text { (mg/L) }\end{array}$ \\
\hline \multirow[t]{3}{*}{$\mathrm{BCL}$} & Billy Clapp Lake & $11 / 18 / 91$ & 4.1 & 2.2 & 7 & 0.1 & 0.80 & 73 & 0 & 62 & 8.6 & 1.6 \\
\hline & & $03 / 02 / 92$ & 4.3 & 2.3 & 7 & 0.1 & 0.80 & 69 & 0 & 58 & 9.8 & 1.5 \\
\hline & & $07 / 13 / 92$ & 4.4 & 2.2 & 7 & 0.1 & 0.70 & 76 & 0 & 62 & 9.9 & 1.0 \\
\hline \multirow[t]{3}{*}{ RFC } & Rocky Ford Creek & $11 / 18 / 91$ & 14 & 22 & 24 & 0.8 & 7.5 & 200 & 0 & 166 & 25 & 6.0 \\
\hline & & $03 / 02 / 92$ & & 23 & 25 & 0.9 & 7.9 & 195 & 0 & 158 & 23 & 6.3 \\
\hline & & $07 / 13 / 92$ & 14 & 25 & 27 & 0.9 & 7.7 & 192 & 5 & 165 & 27 & 5.0 \\
\hline $\mathrm{CCU}$ & Upper Crab Creek & $07 / 14 / 92$ & 23 & 18 & 14 & 0.5 & 4.2 & 303 & 0 & 248 & 16 & 1.2 \\
\hline \multirow[t]{3}{*}{ MLR } & Moses Lake, & $11 / 18 / 91$ & 12 & 19 & 25 & 0.7 & 4.1 & 146 & 12 & 139 & 20 & 4.4 \\
\hline & Rocky Ford arm & $03 / 02 / 92$ & 15 & 23 & 28 & 0.9 & 5.6 & 143 & 15 & 145 & 21 & 7.2 \\
\hline & & $07 / 14 / 92$ & 9.7 & 12 & 21 & 0.5 & 3.1 & 112 & 10 & 109 & 18 & 2.7 \\
\hline MLP & $\begin{array}{l}\text { Moses Lake, } \\
\text { Parker Horn arm }\end{array}$ & $07 / 14 / 92$ & 14 & 14 & 18 & 0.5 & 3.7 & 155 & 13 & 147 & 20 & 3.2 \\
\hline \multirow[t]{3}{*}{ MLS } & Moses Lake, & $11 / 19 / 91$ & 11 & 15 & 21 & 0.6 & 3.3 & 143 & 9 & 129 & 17 & 4.2 \\
\hline & south end & $03 / 03 / 92$ & 16 & 23 & 25 & 0.8 & 4.5 & 178 & 10 & 163 & 22 & 8.0 \\
\hline & & $07 / 14 / 92$ & 9.3 & 11 & 19 & 0.5 & 2.9 & 123 & 4 & 105 & 17 & 2.6 \\
\hline \multirow[t]{3}{*}{ PRW } & Potholes Reservoir, & $11 / 19 / 91$ & 29 & 37 & 25 & 1 & 13 & 274 & 12 & 243 & 41 & 9.6 \\
\hline & west arm & $03 / 03 / 92$ & 17 & 23 & 25 & 0.8 & 5.0 & 182 & 7 & 158 & 30 & 9.3 \\
\hline & & $07 / 15 / 92$ & 28 & 38 & 25 & 1 & 11 & 344 & 0 & 277 & 35 & 12 \\
\hline PRE & $\begin{array}{l}\text { Potholes Reservoir, } \\
\text { east arm }\end{array}$ & $07 / 15 / 92$ & 12 & 15 & 20 & 0.6 & 4.5 & 139 & 13 & 135 & 13 & 5.6 \\
\hline \multirow[t]{3}{*}{ Ww } & Winchester & $11 / 18 / 91$ & 16 & 30 & 25 & 0.9 & 6.1 & 257 & 0 & 211 & 35 & 12 \\
\hline & Wasteway & $03 / 02 / 92$ & 18 & 30 & 25 & 0.9 & 6,2 & 231 & 11 & 206 & 38 & 13 \\
\hline & & $07 / 15 / 92$ & 13 & 17 & 21 & 0.6 & 3.9 & 172 & 0 & 141 & 23 & 6.4 \\
\hline \multirow[t]{3}{*}{ FHW } & Frenchman Hills & $11 / 21 / 91$ & 26 & 33 & 24 & 1 & 6.1 & 240 & 7 & 209 & 59 & 18 \\
\hline & Wasteway & $03 / 03 / 92$ & 30 & 40 & 25 & 1 & 7.2 & 254 & 8 & 222 & 72 & 22 \\
\hline & & $07 / 15 / 92$ & 14 & 18 & 21 & 0.7 & 3.0 & 160 & 0 & 130 & 27 & 9.8 \\
\hline \multirow[t]{3}{*}{ LCW } & Lind Coulce & $11 / 18 / 91$ & 19 & 52 & 36 & 2 & 6.4 & 240 & 8 & 209 & 75 & 18 \\
\hline & Wasteway & $03 / 02 / 92$ & 20 & 52 & 35 & 2 & 6.6 & 242 & 7 & 208 & 76 & 21 \\
\hline & & $07 / 14 / 92$ & 10 & 17 & 23 & 0.7 & $\mathbf{3 . 0}$ & 144 & 0 & 116 & 25 & 6.8 \\
\hline \multirow[t]{3}{*}{ SL } & Soda Lake & $11 / 20 / 91$ & 15 & 22 & 25 & 0.8 & 4.3 & 197 & 0 & 160 & 28 & 8.2 \\
\hline & & $03 / 04 / 92$ & 16 & 23 & 25 & 0.8 & 5.5 & 179 & 6 & 157 & 27 & 9.1 \\
\hline & & $07 / 17 / 92$ & 13 & 19 & 26 & 0.8 & 3.9 & 140 & 7 & 126 & 24 & 8.9 \\
\hline $\mathrm{CCM}$ & $\begin{array}{l}\text { Lower Crab Creek, } \\
\text { McManamon Road }\end{array}$ & $07 / 15 / 92$ & 9.5 & 18 & 27 & 0.8 & 3.7 & 123 & 7 & 112 & 20 & 6.9 \\
\hline LGL & Lower Goose Lake & $07 / 17 / 92$ & 9.8 & 22 & 31 & 0.9 & 3.2 & 142 & 0 & 115 & 28 & 11 \\
\hline SHCb & $\begin{array}{l}\text { Sand Hollow Creek } \\
\text { at mouth }\end{array}$ & $11 / 20 / 91$ & 32 & 29 & 17 & 0.7 & 2.6 & 262 & 13 & 235 & 72 & 26 \\
\hline \multirow[t]{2}{*}{ SHCa } & Sand Hollow Creek, & $03 / 04 / 92$ & 34 & 35 & 20 & 0.9 & 1.7 & 269 & 17 & 249 & 71 & 26 \\
\hline & at Road S, SW & $07 / 16 / 92$ & 17 & 15 & 16 & 0.5 & 1.5 & 169 & 5 & 146 & 26 & 8.7 \\
\hline \multirow[t]{3}{*}{$\mathrm{CCB}$} & Crab Creek near & $11 / 21 / 91$ & 29 & 79 & 40 & 2 & 11 & 343 & 15 & 301 & 77 & 25 \\
\hline & Beverly & $03 / 05 / 92$ & 31 & 84 & 41 & 2 & 9.7 & 334 & 16 & 298 & 99 & 32 \\
\hline & & $07 / 16 / 92$ & 21 & 46 & 34 & 1 & 6.8 & 238 & 10 & 211 & S5 & 17 \\
\hline SMW & $\begin{array}{l}\text { Saddle Mountain } \\
\text { Wasteway }\end{array}$ & $07 / 17 / 92$ & 16 & 26 & 28 & 1 & 3.5 & 146 & 10 & 136 & 39 & 13 \\
\hline
\end{tabular}


Table 25.--Field measurements and results of analyses for inorganic constituents in filtered water samples from the Columbia Basin Project, November 1991, March 1992, and July 1992--Continued

\begin{tabular}{|c|c|c|c|c|c|c|c|c|c|c|c|c|}
\hline $\begin{array}{l}\text { Map } \\
\text { identi- } \\
\text { fier } \\
\text { (fig. 9) }\end{array}$ & Station name & Date & $\begin{array}{l}\text { Mag- } \\
\text { nesium } \\
\text { (mg/L) }\end{array}$ & $\begin{array}{l}\text { Sodium } \\
\text { (mg/L) }\end{array}$ & $\begin{array}{l}\text { Per- } \\
\text { cent } \\
\text { sod- } \\
\text { ium }\end{array}$ & $\begin{array}{l}\text { Sodium } \\
\text { ad- } \\
\text { sorp- } \\
\text { tion } \\
\text { ratio }\end{array}$ & $\begin{array}{l}\text { Potas- } \\
\text { sium } \\
\text { (mg/L) }\end{array}$ & $\begin{array}{l}\text { Bicar- } \\
\text { bonate } \\
(\mathrm{mg} / \mathrm{L} \\
\text { as } \\
\left.\mathrm{HCO}_{3}\right)\end{array}$ & $\begin{array}{l}\text { Car- } \\
\text { bonate } \\
(\mathrm{mg} / \mathrm{L} \\
\text { as } \\
\left.\mathrm{CO}_{3}\right)\end{array}$ & $\begin{array}{l}\text { Alka- } \\
\text { linity } \\
\text { (mg/L } \\
\text { as } \\
\mathrm{CaCO}_{3} \text { ) }\end{array}$ & $\begin{array}{l}\text { Sul- } \\
\text { fate } \\
\text { (mg/L) }\end{array}$ & $\begin{array}{l}\text { Chlo- } \\
\text { ride } \\
(\mathrm{mg} / \mathrm{L})\end{array}$ \\
\hline \multirow[t]{3}{*}{ ELW } & EL68D Wasteway & $11 / 19 / 91$ & 32 & 64 & 36 & 2 & 3.3 & 316 & 12 & 277 & 71 & 21 \\
\hline & & $03 / 04 / 92$ & 33 & 72 & 31 & 2 & 5.8 & 298 & 17 & 270 & 130 & 41 \\
\hline & & $07 / 14 / 92$ & 14 & 19 & 25 & 0.7 & 1.8 & 146 & 0 & 121 & 27 & 5.2 \\
\hline \multirow[t]{3}{*}{ WBWa } & Wahluke Branch & $11 / 19 / 91$ & 36 & 87 & 37 & 2 & 5.3 & 439 & 1 & 359 & 100 & 30 \\
\hline & 10A Wasteway & $03 / 04 / 92$ & 38 & 95 & 39 & 2 & 6.4 & 415 & 5 & 347 & 100 & 34 \\
\hline & & $07 / 17 / 92$ & 21 & 40 & 32 & 1 & 4.0 & 226 & 7 & 196 & 45 & 17 \\
\hline \multirow[t]{3}{*}{ PEW } & PE16.4 Wasteway & $11 / 20 / 91$ & 23 & 41 & 30 & 1 & 4.3 & 243 & 7 & 211 & 63 & 18 \\
\hline & & $03 / 03 / 92$ & 36 & 70 & 37 & 2 & 2.8 & 339 & 6 & 286 & 70 & 23 \\
\hline & & $07 / 16 / 92$ & 20 & 35 & 29 & 1 & 4.9 & 199 & 14 & 187 & 51 & 15 \\
\hline \multirow[t]{4}{*}{ ECW } & Esquatzel Coulee & $11 / 20 / 91$ & 22 & 43 & 30 & 1 & 4.5 & 261 & 1 & 215 & 66 & 20 \\
\hline & Wasteway & $03 / 03 / 92$ & 28 & 56 & 30 & 1 & 5.2 & 284 & 4 & 239 & 90 & 31 \\
\hline & & $07 / 16 / 92$ & 16 & 28 & 28 & 1 & 3.5 & 185 & 0 & 151 & 41 & 14 \\
\hline & \multicolumn{12}{|c|}{ Duplicate Samples } \\
\hline $\mathrm{SHCb}$ & $\begin{array}{l}\text { Sand Hollow Creek } \\
\text { at mouth }\end{array}$ & $11 / 20 / 91$ & 31 & 29 & 17 & 0.7 & 2.6 & 257 & 14 & 231 & 71 & 26 \\
\hline PRW & $\begin{array}{l}\text { Potholes Reservoir, } \\
\text { west arm }\end{array}$ & $03 / 03 / 92$ & 17 & 23 & 25 & 0.8 & 4.8 & 180 & 6 & 158 & 30 & 9.3 \\
\hline PRE & $\begin{array}{l}\text { Potholes Reservoir, } \\
\text { east arm }\end{array}$ & $07 / 15 / 92$ & 12 & 15 & 20 & 0.6 & 4.3 & 140 & 13 & 136 & 13 & 5.6 \\
\hline Ww & $\begin{array}{l}\text { Winchester } \\
\text { Wasteway }\end{array}$ & $07 / 15 / 92$ & 13 & 17 & 20 & 0.6 & 4.0 & 171 & 0 & 139 & 23 & 7.7 \\
\hline
\end{tabular}


Table 25. --Field measurements and results of analyses for inorganic constituents in filtered water samples from the Columbia Basin Project, November 1991, March 1992, and July 1992--Continued

\begin{tabular}{|c|c|c|c|c|c|c|c|c|c|c|c|}
\hline $\begin{array}{l}\text { Map } \\
\text { identi- } \\
\text { fier } \\
\text { (fig. 9) }\end{array}$ & Station name & Date & $\begin{array}{l}\text { Fluo- } \\
\text { ride } \\
(\mathrm{mg} / \mathrm{L})\end{array}$ & $\begin{array}{l}\text { Dis- } \\
\text { solved } \\
\text { solids, } \\
\text { residue } \\
\text { at } 180 \\
\text { degrees } \\
\text { Celsius } \\
\text { (mg/L) }\end{array}$ & $\begin{array}{l}\text { Dis- } \\
\text { solved } \\
\text { solids } \\
\text { (tons } \\
\text { per day) }\end{array}$ & $\begin{array}{l}\text { Nit- } \\
\text { rite + } \\
\text { nitrate } \\
\text { nitro- } \\
\text { gen } \\
\text { (mg/L) }\end{array}$ & $\begin{array}{l}\text { Ammonia } \\
\text { nitrogen } \\
(\mathrm{mg} / \mathrm{L})\end{array}$ & $\begin{array}{l}\text { Ortho } \\
\text { phos- } \\
\text { phorus } \\
\text { (mg/L) }\end{array}$ & $\begin{array}{l}\text { Arsenic } \\
(\mu g / L)\end{array}$ & $\begin{array}{l}\text { Boron } \\
(\mu g / L)\end{array}$ & $\begin{array}{l}\text { Cad- } \\
\text { mium } \\
(\mu g / L)\end{array}$ \\
\hline \multirow[t]{3}{*}{$\mathrm{BCL}$} & Billy Clapp Lake & $11 / 18 / 91$ & 0.20 & 88 & - & $<0.050$ & 0.020 & 0.010 & $<1$ & $<10$ & $<1.0$ \\
\hline & & 03/02/92 & 0.10 & 91 & -- & $<0.050$ & $<0.010$ & $<0.010$ & $<1$ & 30 & $<1.0$ \\
\hline & & $07 / 13 / 92$ & 0.10 & 82 & -- & $<0.050$ & 0.030 & $<0.010$ & $<1$ & $<10$ & $<1.0$ \\
\hline \multirow[t]{3}{*}{ RFC } & Rocky Ford Creek & $11 / 18 / 91$ & 0.40 & 252 & 42.4 & 1.70 & 0.200 & 0.200 & 2 & 20 & $<1.0$ \\
\hline & & $03 / 02 / 92$ & 0.50 & 247 & 24.9 & 1.50 & 0.190 & 0.210 & 2 & 20 & $<1.0$ \\
\hline & & $07 / 13 / 92$ & 0.40 & 241 & 24.9 & 0.190 & 0.030 & 0.140 & 2 & $<10$ & $<1.0$ \\
\hline $\mathrm{CCU}$ & Upper Crab Creek & $07 / 14 / 92$ & 0.40 & 275 & 40.3 & 0.890 & 0.030 & 0.010 & 2 & 20 & $<1.0$ \\
\hline \multirow[t]{3}{*}{ MLR } & Moses Lake, & $11 / 18 / 91$ & 0.20 & 182 & -- & 0.290 & 0.010 & 0.010 & 3 & 10 & $<1.0$ \\
\hline & Rocky Ford arm & $03 / 02 / 92$ & 0.40 & 201 & - & 0.320 & 0.010 & $<0.010$ & 3 & 40 & $<1.0$ \\
\hline & & $07 / 14 / 92$ & 0.20 & 135 & - & $<0.050$ & 0.030 & $<0.010$ & 2 & 10 & $<1.0$ \\
\hline MLP & $\begin{array}{l}\text { Moses Lake, } \\
\text { Parker Horn arm }\end{array}$ & $07 / 14 / 92$ & 0.30 & 174 & - & 0.170 & 0.030 & $<0.010$ & 2 & $<10$ & $<1.0$ \\
\hline \multirow[t]{3}{*}{ MLS } & Moses Lake, & $11 / 19 / 91$ & 0.20 & 182 & - & 0.200 & 0.020 & $<0.010$ & 2 & 10 & $<1.0$ \\
\hline & south end & $03 / 03 / 92$ & 0.30 & 210 & -- & 0.330 & $<0.010$ & $<0.010$ & 2 & 10 & $<1.0$ \\
\hline & & $07 / 14 / 92$ & 0.30 & 129 & - & $<0.050$ & 0.020 & $<0.010$ & 2 & $<10$ & $<1.0$ \\
\hline \multirow[t]{3}{*}{ PRW } & Potholes Reservoir, & $11 / 19 / 91$ & 0.30 & 338 & - & 0.920 & 0.010 & $<0.010$ & 3 & 30 & $<1.0$ \\
\hline & west arm & $03 / 03 / 92$ & 0.40 & 216 & - & 0.300 & $<0.010$ & $<0.010$ & 3 & 20 & $<1.0$ \\
\hline & & $07 / 15 / 92$ & 0.40 & 349 & - & $<0.050$ & $<0.010$ & $<0.010$ & 2 & 30 & $<1.0$ \\
\hline PRE & $\begin{array}{l}\text { Potholes Reservoir, } \\
\text { cast arm }\end{array}$ & $07 / 15 / 92$ & 0.30 & 161 & - & $<0.050$ & $<0.010$ & $<0.010$ & 3 & $<10$ & $<1.0$ \\
\hline \multirow[t]{3}{*}{ WW } & Winchester & $11 / 18 / 91$ & 0.30 & 314 & 112 & 2.00 & 0.010 & $<0.010$ & $<1$ & 20 & $<1.0$ \\
\hline & Wasteway & $03 / 02 / 92$ & 0.40 & 323 & 66.0 & 1.90 & 0.040 & $<0.010$ & 8 & 20 & $<1.0$ \\
\hline & & $07 / 15 / 92$ & 0.30 & 216 & 63.0 & 0.350 & $<0.010$ & $<0.010$ & 4 & 10 & $<1.0$ \\
\hline \multirow[t]{3}{*}{ FHW } & Frenchman Hills & $11 / 21 / 91$ & 0.50 & 376 & 282 & 5.40 & 0.020 & 0.180 & 7 & 20 & $<1.0$ \\
\hline & Wasteway & $03 / 03 / 92$ & 0.60 & 415 & 176 & 6.00 & $<0.010$ & 0.420 & 9 & 150 & $<1.0$ \\
\hline & & $07 / 15 / 92$ & 0.30 & 201 & 307 & 2.10 & $<0.010$ & 0.050 & 4 & 20 & $<1.0$ \\
\hline \multirow[t]{3}{*}{ LCW } & Lind Coulee & $11 / 18 / 91$ & 0.70 & 398 & 114 & 4.30 & 0.020 & 0.060 & 7 & 30 & $<1.0$ \\
\hline & Wasteway & $03 / 02 / 92$ & 0.70 & 403 & 63.4 & 4.70 & 0.020 & 0.050 & 12 & 10 & $<1.0$ \\
\hline & & $07 / 14 / 92$ & 0.30 & 177 & 173 & 1.70 & 0.040 & 0.040 & 4 & $<10$ & $<1.0$ \\
\hline \multirow[t]{3}{*}{ SL } & Soda Lake & $11 / 20 / 91$ & 0.30 & 215 & -- & 0.560 & 0.620 & 0.080 & 3 & 20 & $<1.0$ \\
\hline & & $03 / 04 / 92$ & 0.40 & 217 & - & 0.660 & 0.550 & 0.050 & 4 & 20 & $<1.0$ \\
\hline & & $07 / 17 / 92$ & 0.30 & 168 & -- & 0.270 & 0.240 & 0.040 & 4 & 10 & $<1.0$ \\
\hline $\mathrm{CCM}$ & $\begin{array}{l}\text { Lower Crab Creek, } \\
\text { McManamon Road }\end{array}$ & $07 / 15 / 92$ & 0.30 & 156 & 28.6 & $<0.050$ & 0.020 & 0.010 & 2 & $<10$ & $<1.0$ \\
\hline LGL & Lower Goose Lake & $07 / 17 / 92$ & 0.20 & 168 & -- & 0.110 & 0.260 & 0.030 & 2 & 10 & $<1.0$ \\
\hline SHCb & $\begin{array}{l}\text { Sand Hollow Creek } \\
\text { at mouth }\end{array}$ & $11 / 20 / 91$ & 0.50 & 452 & 40.2 & 10.0 & 0.010 & 0.020 & 3 & 30 & $<1.0$ \\
\hline \multirow[t]{2}{*}{ SHCa } & Sand Hollow Creek & $03 / 04 / 92$ & 0.50 & 447 & 14.0 & 12.0 & 0.020 & $<0.010$ & $<1$ & 30 & $<1.0$ \\
\hline & at Raad S, SW & $07 / 16 / 92$ & 0.40 & 243 & - & 5.50 & 0.060 & 0.020 & 2 & 30 & $<1.0$ \\
\hline \multirow[t]{3}{*}{ CCB } & Crab Creek near & $11 / 21 / 91$ & 0.50 & 516 & 371 & 2.90 & 0.020 & 0.050 & 6 & 40 & $<1.0$ \\
\hline & Beverly & $03 / 05 / 92$ & 0.70 & 520 & - & 2.70 & 0.020 & 0.020 & 8 & 20 & $<1.0$ \\
\hline & & $07 / 16 / 92$ & 0.50 & 320 & 232 & 1.10 & 0.020 & $<0.010$ & 5 & 30 & $<1.0$ \\
\hline SMW & $\begin{array}{l}\text { Saddle Mountain } \\
\text { Wasteway }\end{array}$ & $07 / 17 / 92$ & 0.40 & 214 & 29.3 & 1.30 & 0.030 & $<0.010$ & 4 & 20 & $<1.0$ \\
\hline
\end{tabular}


Table 25.--Field measurements and results of analyses for inorganic constituents in filtered water samples from the Columbia Basin Project, November 1991, March 1992, and July 1992--Continued

\begin{tabular}{|c|c|c|c|c|c|c|c|c|c|c|c|}
\hline $\begin{array}{l}\text { Map } \\
\text { identi- } \\
\text { fier } \\
\text { (fig. 9) }\end{array}$ & Station name & Date & $\begin{array}{l}\text { Fluo- } \\
\text { ride } \\
\text { (mg/L) }\end{array}$ & $\begin{array}{l}\text { Dis- } \\
\text { solved } \\
\text { solids, } \\
\text { residue } \\
\text { at } 180 \\
\text { degrees } \\
\text { Celsius } \\
\text { (mg/L) }\end{array}$ & $\begin{array}{l}\text { Dis- } \\
\text { solved } \\
\text { solids } \\
\text { (tons } \\
\text { per day) }\end{array}$ & $\begin{array}{l}\text { Nit- } \\
\text { rite + } \\
\text { nitrate } \\
\text { nitro- } \\
\text { gen } \\
(\mathrm{mg} / \mathrm{L})\end{array}$ & $\begin{array}{l}\text { Ammonia } \\
\text { nitrogen } \\
\text { (mg/L) }\end{array}$ & $\begin{array}{l}\text { Ortho } \\
\text { phos- } \\
\text { phorus } \\
\text { (mg/L) }\end{array}$ & $\begin{array}{l}\text { Arsenic } \\
(\mu / /))\end{array}$ & $\begin{array}{l}\text { Boron } \\
(\mu g / L)\end{array}$ & $\begin{array}{l}\text { Cad- } \\
\text { mium } \\
(\mu g / L)\end{array}$ \\
\hline \multirow[t]{3}{*}{$\mathbf{E} \mathbf{W}$} & BL68D Wasteway & $11 / 19491$ & 0.60 & 475 & 60.3 & 7.70 & 0.020 & 0.020 & 7 & 60 & $<1.0$ \\
\hline & & $03 / 04 / 92$ & 0.30 & 584 & 19.9 & 7.60 & 0.020 & $<0.010$ & 6 & 40 & $<1.0$ \\
\hline & & $07 / 14 / 92$ & 0.30 & 194 & 120 & 3.80 & 0.280 & 0.040 & 2 & 20 & $<1.0$ \\
\hline \multirow[t]{3}{*}{ WBWa } & Wahluke Branch & $11 / 19 / 91$ & 0.70 & 608 & 7.21 & 8.40 & 0.030 & 0.020 & 6 & 100 & $<1.0$ \\
\hline & 10A Wasteway & 0310492 & 0.70 & 615 & 4.08 & 9.70 & 0.020 & $<0.010$ & 6 & 80 & $<1.0$ \\
\hline & & $07 / 17 / 92$ & 0.40 & 312 & 14.1 & 3.10 & 0.040 & $<0.010$ & 5 & 40 & $<1.0$ \\
\hline \multirow[t]{3}{*}{ PEW } & PE16.4 Wasteway & $11 / 2091$ & 0.40 & 358 & 137 & 3.40 & 0.030 & $<0.010$ & 3 & 40 & $<1.0$ \\
\hline & & $03 / 03 / 92$ & 0.60 & 452 & 31.2 & 7.90 & $<0.010$ & $<0.010$ & 8 & 50 & $<1.0$ \\
\hline & & $07 / 1692$ & 0.40 & 290 & 71.6 & 2.00 & 0.030 & $<0.010$ & 5 & 30 & $<1.0$ \\
\hline \multirow[t]{4}{*}{ ECW } & Esquatrel Coulee & $11 / 20 / 91$ & 0.40 & 373 & 103 & 4.50 & 0.030 & 0.010 & 4 & 40 & $<1.0$ \\
\hline & Wasteway & $03 / 03 / 92$ & 0.50 & 478 & 34.5 & 6.80 & $<0.010$ & 0.010 & 7 & 30 & $<1.0$ \\
\hline & & $07 / 16 \times 92$ & 0.30 & 249 & 67.2 & 2.40 & 0.050 & 0.010 & 4 & 30 & $<1.0$ \\
\hline & \multicolumn{11}{|c|}{ Duplicate Samoles } \\
\hline SHCb & $\begin{array}{l}\text { Sand Hollow Creek } \\
\text { mouth }\end{array}$ & $11 / 20 / 91$ & 0.50 & 452 & 45.4 & 1.0 & $<0.010$ & 0.010 & 3 & 30 & $<1.0$ \\
\hline PRW & $\begin{array}{l}\text { Potholes Reservoir, } \\
\text { west arm }\end{array}$ & $03 / 03 / 92$ & 0.40 & 216 & - & 0.300 & $<0.010$ & $<0.010$ & 3 & 10 & $<1.0$ \\
\hline PRE & $\begin{array}{l}\text { Potholes Reservoir, } \\
\text { east arm }\end{array}$ & $07 / 15 / 92$ & 0.30 & 156 & - & $<0.050$ & $<0.010$ & $<0.010$ & 2 & 10 & $<1.0$ \\
\hline WW & $\begin{array}{l}\text { Winchester } \\
\text { Wasteway }\end{array}$ & $07 / 15 / 92$ & 0.30 & 187 & 54.5 & 0.350 & 0.010 & $<0.010$ & 6 & 20 & $<1.0$ \\
\hline
\end{tabular}


Table 25.--Field measurements and results of analyses for inorganic constituents in filtered water samples from the Columbia Basin Project, November 1991, March 1992, and July 1992--Continued

\begin{tabular}{|c|c|c|c|c|c|c|c|c|c|c|c|}
\hline $\begin{array}{l}\text { Map } \\
\text { identi- } \\
\text { fier } \\
\text { (fig. 9) }\end{array}$ & Station name & Dare & $\begin{array}{l}\text { Chro- } \\
\text { minu } \\
(\mu / /)\end{array}$ & $\begin{array}{l}\text { Copper } \\
(\mu \circ / L)\end{array}$ & $\begin{array}{l}\text { Lead } \\
(\mu \sigma / L)\end{array}$ & $\begin{array}{l}\text { Mencury } \\
(\mu \circ / L)\end{array}$ & $\begin{array}{l}\text { Molyb- } \\
\text { denum } \\
\text { (no/L) }\end{array}$ & $\begin{array}{l}\text { Sele- } \\
\text { nium } \\
(\mu \rho / \Omega)\end{array}$ & $\begin{array}{l}\text { Vana- } \\
\text { dium } \\
(\mu g / L)\end{array}$ & $\begin{array}{l}\text { Zinc } \\
(\mu g / L)\end{array}$ & $\begin{array}{l}\text { Total } \\
\text { natural } \\
\text { uranium } \\
(\mu g / L)\end{array}$ \\
\hline \multirow[t]{3}{*}{$\mathrm{BCl}$} & Billy Clapp Lake & $11 / 18 / 91$ & $<1$ & 1 & $<1$ & $<0.1$ & $<1$ & $<1$ & 1 & $<3$ & -- \\
\hline & & $03 / 02 / 92$ & $<1$ & 4 & $<1$ & $<0.1$ & $<1$ & $<1$ & 1 & 5 & - \\
\hline & & $07 / 13 / 92$ & $<1$ & 1 & $<1$ & $<0.1$ & $<1$ & $<1$ & 1 & $<3$ & 1.4 \\
\hline \multirow[t]{3}{*}{ RFC } & Rocky Ford Creek & $11 / 18 / 91$ & $<1$ & $<1$ & $<1$ & $<0.1$ & 1 & 1 & 11 & 5 & -- \\
\hline & & $03 / 02 / 92$ & $<1$ & $<1$ & $<1$ & 0.2 & 1 & $<1$ & 12 & $<3$ & - \\
\hline & & $07 / 13 / 92$ & $<1$ & $<1$ & $<1$ & $<0.1$ & 1 & $<1$ & 19 & $<3$ & 1.9 \\
\hline $\mathrm{CCU}$ & Upper Crab Creek & $07 / 14 / 92$ & $<1$ & $<1$ & $<1$ & $<0.1$ & $<1$ & $<1$ & 13 & $<$ & 3.3 \\
\hline \multirow[t]{3}{*}{ MLR } & Moses Lake, & $11 / 18 / 91$ & $<1$ & $<1$ & $<1$ & $<0.1$ & $<1$ & $<1$ & 15 & 4 & -- \\
\hline & Rocky Ford arm & $03 / 02 / 92$ & $<1$ & 2 & $<1$ & $<0.1$ & 1 & $<1$ & 17 & $<3$ & - \\
\hline & & $07 / 14 / 92$ & $<1$ & $<1$ & $<1$ & $<0.1$ & $<1$ & $<1$ & 8 & $<$ & 1.6 \\
\hline MLP & $\begin{array}{l}\text { Moses Lake, } \\
\text { Parker Horn arm }\end{array}$ & $07 / 14 / 92$ & $<1$ & 1 & $<1$ & $<0.1$ & 1 & $<1$ & 12 & $<3$ & 2.3 \\
\hline \multirow[t]{3}{*}{ MLS } & Moses Lake, & $11 / 19 / 91$ & $<1$ & 1 & 3 & $<0.1$ & 1 & $<1$ & 11 & 6 & - \\
\hline & south end & $03 / 03 / 92$ & $<1$ & $<1$ & $<1$ & $<0.1$ & 1 & $<1$ & 14 & $<3$ & -- \\
\hline & & $07 / 14 / 92$ & $<1$ & $<1$ & $<1$ & $<0.1$ & $<1$ & $<1$ & 7 & $<$ & 1.2 \\
\hline \multirow[t]{3}{*}{ PRW } & Potholes Reservoir, & $11 / 19 / 91$ & $<1$ & $<1$ & $<1$ & $<0.1$ & 2 & $<1$ & 12 & 7 & -- \\
\hline & west arm & $03 / 03 / 92$ & $<1$ & 1 & $<1$ & $<0.1$ & 1 & $<1$ & 10 & $<3$ & -- \\
\hline & & $07 / 15 / 92$ & $<1$ & $<1$ & $<1$ & $<0.1$ & $<1$ & $<1$ & 3 & $<3$ & 2.7 \\
\hline PRE & $\begin{array}{l}\text { Potholes Reservoir, } \\
\text { east arm }\end{array}$ & $07 / 15 / 92$ & $<1$ & $<1$ & $<1$ & $<0.1$ & $<1$ & $<1$ & 8 & $<3$ & 1.2 \\
\hline \multirow[t]{3}{*}{ ww } & Winchester & $11 / 18 / 91$ & $<1$ & $<1$ & $<1$ & 0.2 & 5 & $<1$ & 20 & $<3$ & - \\
\hline & Wasteway & $03 / 02 / 92$ & $<1$ & $<1$ & $<1$ & $<0.1$ & 3 & $<1$ & 29 & $<3$ & -- \\
\hline & & $07 / 15 / 92$ & $<1$ & $<1$ & $<1$ & $<0.1$ & 1 & $<1$ & 25 & 4 & 1.9 \\
\hline \multirow[t]{3}{*}{ FHW } & Frenchman Hills & $11 / 21 / 91$ & $<1$ & $<1$ & $<1$ & $<0.1$ & 4 & $<1$ & 31 & 8 & - \\
\hline & Wasteway & $03 / 03 / 92$ & $<1$ & 1 & $<1$ & $<0.1$ & 4 & $<1$ & 37 & 7 & - \\
\hline & & $07 / 15 / 92$ & $<1$ & 1 & $<1$ & $<0.1$ & 1 & $<1$ & 16 & $<3$ & 2.4 \\
\hline \multirow[t]{3}{*}{ LCW } & Lind Coulee & $11 / 18 / 91$ & $<1$ & $<1$ & $<1$ & $<0.1$ & 1 & $<1$ & 30 & 3 & -- \\
\hline & Wasteway & $03 / 02 / 92$ & $<1$ & $<1$ & $<1$ & $<0.1$ & 6 & $<1$ & 33 & $<3$ & - \\
\hline & & $07 / 14 / 92$ & $<1$ & 2 & $<1$ & $<0.1$ & 2 & $<1$ & 13 & $<$ & 2.4 \\
\hline \multirow[t]{3}{*}{ SL } & Soda Lake & $11 / 20 / 91$ & $<1$ & 1 & $<1$ & $<0.1$ & 2 & $<1$ & 11 & 5 & 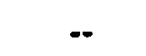 \\
\hline & & $03 / 04 / 92$ & $<1$ & $<1$ & $<1$ & $<0.1$ & 1 & $<1$ & 9 & $<3$ & -- \\
\hline & & $07 / 17 / 92$ & $<1$ & 1 & $<1$ & $<0.1$ & 2 & $<1$ & 10 & 4 & 2.6 \\
\hline $\mathrm{CCM}$ & $\begin{array}{l}\text { Lower Crab Creek, } \\
\text { McManamon Road }\end{array}$ & $07 / 15 / 92$ & $<1$ & 2 & $<1$ & $<0.1$ & 1 & $<1$ & 5 & $<$ & 1.3 \\
\hline LGL & Lower Goose Lake & $07 / 17 / 92$ & $<1$ & 1 & $<1$ & $<0.1$ & 1 & $<1$ & 4 & $<3$ & 1.7 \\
\hline SHCb & $\begin{array}{l}\text { Sand Hollow Creek } \\
\text { at mouth }\end{array}$ & $11 / 20 / 91$ & $<1$ & $<1$ & $<1$ & $<0.1$ & 3 & $<1$ & 17 & $<3$ & - \\
\hline \multirow[t]{2}{*}{ SHCa } & Sand Hollow Creek & $03 / 04 / 92$ & $<1$ & $<1$ & $<1$ & $<0.1$ & 2 & $<1$ & 17 & $<3$ & -- \\
\hline & at Road S, SW & $07 / 16 / 92$ & $<1$ & 2 & $<1$ & $<0.1$ & 1 & $<1$ & 8 & $<3$ & 3.8 \\
\hline \multirow[t]{3}{*}{$\mathrm{CCB}$} & Crab Creek near & $11 / 21 / 91$ & 10 & 5 & 29 & $<0.1$ & 5 & $<1$ & 16 & 13 & -- \\
\hline & Beverly & $03 / 05 / 92$ & 1 & $<1$ & $<1$ & $<0.1$ & 5 & $<1$ & 17 & $<3$ & - \\
\hline & & $07 / 16 / 92$ & $<1$ & 1 & $<1$ & $<0.1$ & 3 & $<1$ & 13 & $<3$ & 4.7 \\
\hline SMW & $\begin{array}{l}\text { Saddle Mountain } \\
\text { Wasteway }\end{array}$ & $07 / 17 / 92$ & $<1$ & 1 & $<1$ & $<0.1$ & 2 & $<1$ & 12 & $<3$ & 4.3 \\
\hline
\end{tabular}


Table 25.--Field measurements and results of analyses for inorganic constituents in filtered water samples from the Columbia Basin Project, November 1991, March 1992, and July 1992--Continued

\begin{tabular}{|c|c|c|c|c|c|c|c|c|c|c|c|}
\hline $\begin{array}{l}\text { Map } \\
\text { identi- } \\
\text { fier } \\
\text { (fig .9) }\end{array}$ & Station name & Date & $\begin{array}{l}\text { Chro- } \\
\text { mium } \\
(\mu / L)\end{array}$ & $\begin{array}{l}\text { Copper } \\
(\mu g / L)\end{array}$ & $\begin{array}{l}\text { Lead } \\
(\mu g / L)\end{array}$ & $\begin{array}{l}\text { Mercury } \\
(\mu g / L)\end{array}$ & $\begin{array}{l}\text { Molyb- } \\
\text { denum } \\
(\mu g / L)\end{array}$ & $\begin{array}{l}\text { Sele- } \\
\text { nium } \\
(\mu / L)\end{array}$ & $\begin{array}{l}\text { Vana- } \\
\text { dium } \\
(\mu g / L)\end{array}$ & $\begin{array}{l}\text { Zinc } \\
(\mu g / L)\end{array}$ & $\begin{array}{l}\text { Total } \\
\text { natural } \\
\text { uranium } \\
(\mu g / L)\end{array}$ \\
\hline \multirow[t]{3}{*}{ ELW } & EL68D Wasteway & $11 / 19 / 91$ & $<1$ & $<1$ & $<1$ & $<0.1$ & 3 & $<1$ & 32 & 5 & -- \\
\hline & & 03/04/92 & $<1$ & $<1$ & $<1$ & 3.0 & 2 & 4 & 13 & $<$ & -. \\
\hline & & $07 / 14 / 92$ & $<1$ & 2 & $<1$ & $<0.1$ & 1 & $<1$ & 12 & $<3$ & 3.1 \\
\hline \multirow[t]{3}{*}{ WBWa } & Wahluke Branch & $11 / 19 / 91$ & $<1$ & 1 & $<1$ & $<0.1$ & 6 & $<1$ & 11 & 8 & - \\
\hline & 10A Wasteway & $03 / 04 / 92$ & 1 & 1 & $<1$ & $<0.1$ & 7 & $<1$ & 11 & $<3$ & - \\
\hline & & 07/17/92 & $<1$ & 1 & $<1$ & 0.1 & 2 & $<1$ & 11 & $<$ & 5.9 \\
\hline \multirow[t]{3}{*}{ PEW } & PE16.4 Wasteway & $11 / 20 / 91$ & $<1$ & $<1$ & $<1$ & $<0.1$ & 2 & $<1$ & 12 & 4 & -- \\
\hline & & 03/03/92 & $<1$ & $<1$ & $<1$ & $<0.1$ & 3 & 2 & 31 & $<3$ & -- \\
\hline & & $07 / 16 / 92$ & $<1$ & 1 & $<1$ & $<0.1$ & 2 & 1 & 13 & $<3$ & 4.5 \\
\hline \multirow[t]{4}{*}{ ECW } & Esquatzel Coulee & $11 / 20 / 91$ & $<1$ & $<1$ & $<1$ & 0.6 & 3 & $<1$ & 14 & 4 & -- \\
\hline & Wasteway & 03/03/92 & $<1$ & $<1$ & $<1$ & 0.4 & 3 & 2 & 19 & 13 & -- \\
\hline & & $07 / 16 / 92$ & $<1$ & 1 & $<1$ & $<0.1$ & 2 & $<1$ & 11 & $<$ & 4.4 \\
\hline & \multicolumn{11}{|c|}{ Duplicate Samples } \\
\hline $\mathrm{SHCb}$ & $\begin{array}{l}\text { Sand Hollow Creck } \\
\text { at mouth }\end{array}$ & $11 / 20 / 91$ & $<1$ & $<1$ & $<1$ & $<0.1$ & 3 & $<1$ & 16 & $<3$ & -- \\
\hline PRW & $\begin{array}{l}\text { Potholes Reservoir, } \\
\text { west arm }\end{array}$ & $03 / 03 / 92$ & $<1$ & 1 & $<1$ & $<0.1$ & 1 & $<1$ & 10 & $<3$ & - \\
\hline PRE & $\begin{array}{l}\text { Potholes Reservoir, } \\
\text { east arm }\end{array}$ & 07/15/92 & $<1$ & $<1$ & $<1$ & $<0.1$ & 1 & $<1$ & 8 & $<3$ & 1.4 \\
\hline ww & Winchester & $07 / 15 / 92$ & $<1$ & $<1$ & $<1$ & $<0.1$ & $<1$ & $<1$ & 26 & $<$ & 2.4 \\
\hline \multicolumn{12}{|c|}{ Wasteway } \\
\hline
\end{tabular}

${ }^{a}$ Minimum and maximum dissolved oxygen in lake water column. 
Table 26.--Results of analyses for insecticides, herbicides, and other organic compounds in whole water samples from the Columbia Basin Project, November 1991, March 1992, and July 1992

$[\mu \mathrm{g} / \mathrm{L}$, micrograms per liter; <, less than; --, no data]

\begin{tabular}{|c|c|c|c|c|c|c|c|c|c|c|c|}
\hline $\begin{array}{l}\text { Map } \\
\text { identi- } \\
\text { fier } \\
\text { (fig. 9) }\end{array}$ & Station name & Date & $\begin{array}{l}\text { Aldrin } \\
(\mu g / L)\end{array}$ & $\begin{array}{l}\text { Chlor- } \\
\text { dane } \\
(\mu g / L)\end{array}$ & $\begin{array}{l}\text { Chlor- } \\
\text { pyri- } \\
\text { fos } \\
(\mu g / L)\end{array}$ & $\begin{array}{c}\text { DDD } \\
(\mu g / L)\end{array}$ & $\begin{array}{c}\text { DDE } \\
(\mu g / L)\end{array}$ & $\begin{array}{c}\text { DDT } \\
(\mu g / L)\end{array}$ & $\begin{array}{l}\text { Di- } \\
\text { azinon } \\
(\mu g / L)\end{array}$ & $\begin{array}{l}\text { Diel- } \\
\text { drin } \\
(\mu g / L)\end{array}$ & $\begin{array}{l}\text { Disul- } \\
\text { foton } \\
(\mu g / L)\end{array}$ \\
\hline \multirow[t]{3}{*}{$\mathrm{BCL}$} & Billy Clapp Lake & $11 / 18 / 91$ & $<0.001$ & $<0.1$ & $<0.01$ & $<0.001$ & $<0.001$ & $<0.001$ & $<0.01$ & $<0.001$ & $<0.01$ \\
\hline & & $03 / 02 / 92$ & $<0.001$ & $<0.1$ & $<0.01$ & $<0.001$ & $<0.001$ & $<0.001$ & $<0.01$ & $<0.001$ & $<0.01$ \\
\hline & & $07 / 13 / 92$ & $<0.001$ & $<0.1$ & $<0.01$ & $<0.001$ & $<0.001$ & $<0.002$ & $<0.01$ & $<0.001$ & $<0.01$ \\
\hline \multirow[t]{3}{*}{ RFC } & Rocky Ford Creek & $11 / 18 / 91$ & $<0.001$ & $<0.1$ & $<0.01$ & $<0.001$ & $<0.001$ & $<0.001$ & $<0.01$ & $<0.001$ & $<0.01$ \\
\hline & & $03 / 02 / 92$ & $<0.001$ & $<0.1$ & $<0.01$ & $<0.001$ & $<0.001$ & $<0.001$ & $<0.01$ & $<0.001$ & $<0.01$ \\
\hline & & $07 / 13 / 92$ & $<0.001$ & $<0.1$ & $<0.01$ & $<0.001$ & $<0.001$ & $<0.001$ & $<0.01$ & $<0,001$ & $<0.01$ \\
\hline $\mathrm{CCU}$ & Upper Crab Creek & $07 / 14 / 92$ & $<0.001$ & $<0.1$ & $<0.01$ & $<0.001$ & $<0.001$ & $<0.001$ & $<0.01$ & $<0.001$ & $<0.01$ \\
\hline \multirow[t]{3}{*}{ MLR } & Moses Lake, & $11 / 18 / 91$ & $<0.001$ & $<0.1$ & $<0.01$ & $<0.001$ & $<0.001$ & $<0.001$ & $<0.01$ & $<0.001$ & $<0.01$ \\
\hline & Rocky Ford arm & $03 / 02 / 92$ & $<0.001$ & $<0.1$ & $<0.01$ & $<0.001$ & $<0.001$ & $<0.001$ & $<0.01$ & $<0.001$ & $<0.01$ \\
\hline & & $07 / 14 / 92$ & $<0.001$ & $<0.1$ & $<0.01$ & $<0.001$ & $<0.001$ & $<0.001$ & $<0.01$ & $<0.001$ & $<0.01$ \\
\hline MLP & $\begin{array}{l}\text { Moses Lake, } \\
\text { Parker Horn arm }\end{array}$ & $07 / 14 / 92$ & $<0.001$ & $<0.1$ & $<0.01$ & $<0.001$ & $<0.001$ & $<0.001$ & $<0.01$ & $<0.001$ & $<0.01$ \\
\hline \multirow[t]{3}{*}{ MLS } & Moses Lake, & $11 / 19 / 91$ & $<0.001$ & $<0.1$ & $<0.01$ & $<0.001$ & $<0.001$ & $<0.001$ & $<0.01$ & $<0.001$ & $<0.01$ \\
\hline & south end & $03 / 03 / 92$ & $<0.001$ & $<0.1$ & $<0.01$ & $<0.001$ & $<0.001$ & $<0.001$ & $<0.01$ & $<0.001$ & $<0.01$ \\
\hline & & $07 / 14 / 92$ & $<0.001$ & $<0.1$ & $<0.01$ & $<0.001$ & $<0.001$ & $<0.001$ & $<0.01$ & $<0.001$ & $<0.01$ \\
\hline \multirow[t]{3}{*}{ PRW } & Potholes Reservoir, & $11 / 19 / 91$ & $<0.001$ & $<0.1$ & $<0.01$ & $<0.001$ & $<0.001$ & $<0.001$ & $<0.01$ & $<0.001$ & $<0.01$ \\
\hline & west arm & $03 / 03 / 92$ & $<0.001$ & $<0.1$ & $<0.01$ & $<0.001$ & $<0.001$ & $<0.001$ & $<0.01$ & $<0.001$ & $<0.01$ \\
\hline & & $07 / 15 / 92$ & $<0.001$ & $<0.1$ & $<0.01$ & $<0.001$ & $<0.001$ & $<0.001$ & $<0.01$ & $<0.001$ & $<0.01$ \\
\hline PRE & $\begin{array}{l}\text { Potholes Reservoir, } \\
\text { cast arm }\end{array}$ & $07 / 15 / 92$ & $<0.001$ & $<0.1$ & $<0.01$ & $<0.001$ & $<0.001$ & $<0.001$ & $<0.01$ & 0.001 & $<0.01$ \\
\hline \multirow[t]{3}{*}{ WW } & Winchester & $11 / 18 / 91$ & $<0.001$ & $<0.1$ & $<0.01$ & $<0.001$ & $<0.001$ & $<0.001$ & $<0.01$ & $<0.001$ & $<0.01$ \\
\hline & Wasteway & $03 / 02 / 92$ & $<0.001$ & $<0.1$ & $<0.01$ & $<0.001$ & $<0.001$ & $<0.001$ & $<0.01$ & $<0.001$ & $<0.01$ \\
\hline & & $07 / 15 / 92$ & $<0.001$ & $<0.1$ & $<0.01$ & $<0.001$ & $<0.001$ & $<0.001$ & $<0.01$ & $<0.001$ & $<0.01$ \\
\hline \multirow[t]{3}{*}{ FHW } & Frenchman Hills & $11 / 21 / 91$ & $<0.001$ & $<0.1$ & $<0.01$ & $<0.001$ & $<0.001$ & $<0.001$ & $<0.01$ & $<0.001$ & $<0.01$ \\
\hline & Wasteway & $03 / 03 / 92$ & $<0.001$ & $<0.1$ & $<0.01$ & $<0.001$ & $<0.001$ & $<0.001$ & $<0.01$ & $<0.001$ & $<0.01$ \\
\hline & & $07 / 15 / 92$ & $<0.001$ & $<0.1$ & $<0.01$ & $<0.001$ & $<0.001$ & $<0.001$ & $<0.01$ & $<0.001$ & $<0.01$ \\
\hline \multirow[t]{3}{*}{ LCW } & Lind Coulee & $11 / 18 / 91$ & $<0.001$ & $<0.1$ & $<0.01$ & $<0.001$ & $<0.001$ & $<0.001$ & $<0.01$ & $<0.001$ & $<0.01$ \\
\hline & Wasteway & $03 / 02 / 92$ & $<0.001$ & $<0.1$ & $<0.01$ & $<0.001$ & $<0.001$ & $<0.001$ & $<0.01$ & $<0.001$ & $<0.01$ \\
\hline & & $07 / 14 / 92$ & $<0.001$ & $<0.1$ & $<0.01$ & $<0.002$ & $<0.001$ & $<0.001$ & $<0.01$ & $<0.001$ & $<0.01$ \\
\hline \multirow[t]{3}{*}{ SL } & Soda Lake & $11 / 20 / 91$ & $<0.001$ & $<0.1$ & $<0.01$ & $<0.001$ & $<0.001$ & $<0.001$ & $<0.01$ & $<0.001$ & $<0.01$ \\
\hline & & $03 / 04 / 92$ & $<0.001$ & $<0.1$ & $<0.01$ & $<0.001$ & $<0.001$ & $<0.001$ & $<0.01$ & $<0.001$ & $<0.01$ \\
\hline & & $07 / 17 / 92$ & $<0.001$ & $<0.1$ & $<0.01$ & $<0.001$ & $<0.001$ & $<0.001$ & $<0.01$ & $<0.001$ & $<0.01$ \\
\hline $\mathrm{CCM}$ & $\begin{array}{l}\text { Lower Crab Creek, } \\
\text { McManamon Road }\end{array}$ & $07 / 15 / 92$ & $<0.001$ & $<0.1$ & $<0.01$ & $<0.001$ & $<0.001$ & $<0.001$ & $<0.01$ & 0.002 & $<0.01$ \\
\hline LGL & Lower Goose Lake & $07 / 17 / 92$ & $<0.001$ & $<0.1$ & $<0.01$ & $<0.001$ & $<0.001$ & $<0.001$ & $<0.01$ & 0.001 & $<0.01$ \\
\hline SHCb & $\begin{array}{l}\text { Sand Hollow Creek } \\
\text { at inouth }\end{array}$ & $11 / 20 / 91$ & $<0.001$ & $<0.1$ & $<0.01$ & $<0.001$ & $<0.001$ & $<0.001$ & $<0.01$ & $<0.001$ & $<0.01$ \\
\hline \multirow[t]{2}{*}{$\mathrm{SHCa}$} & Sand Hollow Creek & 03/04/92 & $<0.001$ & $<0.1$ & $<0.01$ & $<0.001$ & $<0.001$ & $<0.001$ & $<0.01$ & $<0.001$ & $<0.01$ \\
\hline & at Road S, SW & $07 / 16 / 92$ & $<0.001$ & $<0.1$ & $<0.01$ & $<0.001$ & $<0.001$ & $<0.001$ & $<0.01$ & $<0.001$ & $<0.01$ \\
\hline \multirow[t]{3}{*}{$\mathrm{CCB}$} & Crab Creek near & $11 / 21 / 91$ & $<0.001$ & $<0.1$ & $<0.01$ & $<0.001$ & $<0.001$ & $<0.001$ & $<0.01$ & $<0.001$ & $<0.01$ \\
\hline & Beverly & $03 / 05 / 92$ & $<0.001$ & $<0.1$ & $<0.01$ & $<0.001$ & $<0.001$ & $<0.001$ & $<0.01$ & $<0.001$ & $<0.01$ \\
\hline & & $07 / 16 / 92$ & $<0.001$ & $<0.1$ & $<0.01$ & $<0.001$ & $<0.001$ & $<0.001$ & $<0.01$ & $<0.001$ & $<0.01$ \\
\hline SMW & Saddle Mountain & $07 / 17 / 92$ & $<0.001$ & $<0.1$ & $<0.01$ & $<0.001$ & $<0.001$ & $<0.001$ & $<0.01$ & $<0.001$ & $<0.01$ \\
\hline
\end{tabular}


Table 26.--Results of analyses for insecticides, herbicides, and other organic compounds in whole wcter samples from the Columbia Basin Project, November 1991, March 1992, and July 1992--Continued

\begin{tabular}{|c|c|c|c|c|c|c|c|c|c|c|c|}
\hline $\begin{array}{l}\text { Map } \\
\text { identi- } \\
\text { fier } \\
\text { (fig. 9) }\end{array}$ & Station name & Date & $\begin{array}{l}\text { Aldrin } \\
(\mu g / L)\end{array}$ & $\begin{array}{l}\text { Chlor- } \\
\text { dane } \\
(\mu g / L)\end{array}$ & $\begin{array}{l}\text { Chlor- } \\
\text { pyri- } \\
\text { fos } \\
(\mu g / L)\end{array}$ & $\begin{array}{l}\text { DDD } \\
(\mu g / L)\end{array}$ & $\begin{array}{c}\text { DDE } \\
(\mu g / L)\end{array}$ & $\begin{array}{c}\mathrm{DDT} \\
(\mu \mathrm{g} / \mathrm{L})\end{array}$ & $\begin{array}{l}\text { Di- } \\
\text { azinon } \\
(\mu \mathrm{g} / \mathrm{L})\end{array}$ & $\begin{array}{l}\text { Diel- } \\
\text { drin } \\
(\mu g / L)\end{array}$ & $\begin{array}{l}\text { Disul- } \\
\text { foton } \\
(\mu \mathrm{g} / \mathrm{L})\end{array}$ \\
\hline \multirow[t]{3}{*}{ ELW } & EL68D Wasteway & $11 / 19 / 91$ & $<0.001$ & $<0.1$ & $<0.01$ & $<0.001$ & $<0.001$ & $<0.001$ & $<0.01$ & $<0.001$ & $<0.01$ \\
\hline & & 03/04/92 & $<0.001$ & $<0.1$ & $<0.01$ & $<0.001$ & $<0.001$ & $<0.001$ & $<0.01$ & $<0.001$ & $<0.01$ \\
\hline & & $07 / 14 / 92$ & $<0.001$ & $<0.1$ & 0.03 & $<0.001$ & 0.003 & 0.002 & $<0.01$ & 0.014 & 0.01 \\
\hline \multirow[t]{3}{*}{ WBWa } & Wahluke Branch & $11 / 19 / 91$ & $<0.001$ & $<0.1$ & $<0.01$ & $<0.001$ & $<0.001$ & $<0.001$ & $<0.01$ & $<0.001$ & $<0.01$ \\
\hline & 10A Wasteway & $03 / 04 / 92$ & $<0.001$ & $<0.1$ & $<0.01$ & $<0.001$ & $<0.001$ & $<0.001$ & $<0.01$ & $<0.001$ & $<0.01$ \\
\hline & & $07 / 17 / 92$ & $<0.001$ & $<0.1$ & $<0.01$ & $<0.001$ & $<0.001$ & $<0.001$ & $<0.01$ & $<0.001$ & $<0.01$ \\
\hline \multirow[t]{3}{*}{ PEW } & PE16.4 Wasteway & $11 / 20 / 91$ & $<0.001$ & $<0.1$ & $<0.01$ & $<0.001$ & $<0.001$ & $<0.001$ & $<0.01$ & $<0.001$ & $<0.01$ \\
\hline & & $03 / 03 / 92$ & $<0.001$ & $<0.1$ & $<0.01$ & $<0.001$ & $<0.001$ & $<0.001$ & $<0.01$ & $<0.001$ & $<0.01$ \\
\hline & & $07 / 16 / 92$ & $<0.001$ & $<0.1$ & 0.01 & $<0.001$ & $<0.001$ & $<0.001$ & $<0.01$ & 0.001 & $<0.01$ \\
\hline \multirow[t]{4}{*}{ ECW } & Esquatzel Coulce & $11 / 20 / 91$ & $<0.001$ & $<0.1$ & $<0.01$ & $<0.001$ & $<0.001$ & $<0.001$ & $<0.01$ & $<0.001$ & $<0.01$ \\
\hline & Wasteway & $03 / 03 / 92$ & $<0.001$ & $<0.1$ & $<0.01$ & $<0.001$ & $<0.001$ & $<0.001$ & $<0.01$ & $<0.001$ & $<0.01$ \\
\hline & & $07 / 16 / 92$ & $<0.001$ & $<0.1$ & 0.01 & $<0.001$ & $<0.001$ & $<0.001$ & $<0.01$ & 0.001 & $<0.01$ \\
\hline & \multicolumn{11}{|c|}{ Duplicate Samples } \\
\hline SHCb & $\begin{array}{l}\text { Sand Hollow Creek } \\
\text { at mouth }\end{array}$ & $11 / 20 / 91$ & $<0.001$ & $<0.1$ & $<0.01$ & $<0.001$ & $<0.001$ & $<0.001$ & $<0.01$ & $<0.001$ & $<0.01$ \\
\hline PRW & $\begin{array}{l}\text { Potholes Reservoir, } \\
\text { west arm }\end{array}$ & $03 / 03 / 92$ & $<0.001$ & $<0.1$ & $<0.01$ & $<0.001$ & $<0.001$ & $<0.001$ & $<0.01$ & $<0.001$ & $<0.01$ \\
\hline PRE & $\begin{array}{l}\text { Potholes Reservoir, } \\
\text { cast arm }\end{array}$ & $07 / 15 / 92$ & $<0.001$ & $<0.1$ & $<0.01$ & $<0.001$ & $<0.001$ & $<0.001$ & $<0.01$ & $<0.001$ & $<0.01$ \\
\hline ww & $\begin{array}{l}\text { Winchester } \\
\text { Wasteway }\end{array}$ & $07 / 15 / 92$ & $<0.001$ & $<0.1$ & $<0.01$ & $<0.001$ & $<0.001$ & $<0.001$ & $<0.01$ & $<0.001$ & $<0.01$ \\
\hline
\end{tabular}


Table 26.--Results of analyses for insecticides, herbicides, and other organic compounds in whole wator samples from the Columbia Basin Project, November 1991, March 1992, and July 1992--Continued

\begin{tabular}{|c|c|c|c|c|c|c|c|c|c|c|c|}
\hline $\begin{array}{l}\text { Map } \\
\text { identi- } \\
\text { fier } \\
\text { (fig. 9) }\end{array}$ & Station name & Date & $\begin{array}{l}\text { Endo- } \\
\text { sulfan } \\
(\mu \mathrm{g} / \mathrm{L})\end{array}$ & $\begin{array}{l}\text { Endrin } \\
(\mu g / L)\end{array}$ & $\begin{array}{l}\text { Ethion } \\
(\mu g / L)\end{array}$ & $\begin{array}{l}\text { Ethylan } \\
\text { (Per- } \\
\text { thane) } \\
(\mu \mathrm{g} / \mathrm{L})\end{array}$ & $\begin{array}{l}\text { Fono- } \\
\text { fos } \\
(\mu g / L)\end{array}$ & $\begin{array}{l}\text { Hepta- } \\
\text { chlor } \\
(\mu \mathrm{g} / \mathrm{L})\end{array}$ & $\begin{array}{l}\text { Hepta- } \\
\text { chlor } \\
\text { epo- } \\
\text { xide } \\
(\mu g / L)\end{array}$ & $\begin{array}{l}\text { Lindane } \\
(\mu \mathrm{g} / \mathrm{L})\end{array}$ & $\begin{array}{l}\text { Mala- } \\
\text { thion } \\
(\mu \mathrm{g} / \mathrm{L})\end{array}$ \\
\hline \multirow[t]{3}{*}{ BCL } & Billy Clapp Lake & $11 / 18 / 91$ & $<0.001$ & $<0.001$ & $<0.01$ & $<0.1$ & $<0.01$ & $<0.001$ & $<0.001$ & $<0.001$ & $<0.01$ \\
\hline & & $03 / 02 / 92$ & $<0.001$ & $<0.001$ & $<0.01$ & $<0.1$ & $<0.01$ & $<0.001$ & $<0.001$ & $<0.001$ & $<0.01$ \\
\hline & & $07 / 13 / 92$ & $<0.001$ & $<0.001$ & $<0.01$ & $<0.1$ & $<0.01$ & $<0.001$ & $<0.001$ & $<0.001$ & $<0.01$ \\
\hline \multirow[t]{3}{*}{ RFC } & Rocky Ford Creek & $11 / 18 / 91$ & $<0.001$ & $<0.001$ & $<0.01$ & $<0.1$ & $<0.01$ & $<0.001$ & $<0.001$ & $<0.001$ & $<0.01$ \\
\hline & & $03 / 02 / 92$ & $<0.001$ & $<0.001$ & $<0.01$ & $<0.1$ & $<0.01$ & $<0.001$ & $<0.001$ & $<0.001$ & $<0.01$ \\
\hline & & $07 / 13 / 92$ & $<0.001$ & $<0.003$ & $<0.01$ & $<0.1$ & $<0.01$ & $<0.001$ & $<0.001$ & $<0.001$ & $<0.01$ \\
\hline $\mathrm{CCU}$ & Upper Crab Creek & $07 / 14 / 92$ & $<0.001$ & $<0.001$ & $<0.01$ & $<0.1$ & $<0.01$ & $<0.001$ & $<0.001$ & $<0.001$ & $<0.01$ \\
\hline \multirow[t]{3}{*}{ MLR } & Moses Lake, & $11 / 18 / 91$ & $<0.001$ & $<0.001$ & $<0.01$ & $<0.1$ & $<0.01$ & $<0.001$ & $<0.001$ & $<0.001$ & $<0.01$ \\
\hline & Rocky Ford arm & $03 / 02 / 92$ & $<0.001$ & $<0.001$ & $<0.01$ & $<0.1$ & $<0.01$ & $<0.001$ & $<0.001$ & $<0.001$ & $<0.01$ \\
\hline & & $07 / 14 / 92$ & $<0.001$ & $<0.001$ & $<0.01$ & $<0.1$ & $<0.01$ & $<0.001$ & $<0.001$ & $<0.001$ & $<0.01$ \\
\hline MLP & $\begin{array}{l}\text { Moses Lake, } \\
\text { Parker Hom arm }\end{array}$ & $07 / 14 / 92$ & $<0.001$ & $<0.001$ & $<0.01$ & $<0.1$ & $<0.01$ & $<0.001$ & $<0.001$ & $<0.001$ & $<0.01$ \\
\hline \multirow[t]{3}{*}{ MLS } & Moses Lake, & $11 / 19 / 91$ & $<0.001$ & $<0.001$ & $<0.01$ & $<0.1$ & $<0.01$ & $<0.001$ & $<0.001$ & $<0.001$ & $<0.01$ \\
\hline & south end & $03 / 03 / 92$ & $<0.001$ & $<0.001$ & $<0.01$ & $<0.1$ & $<0.01$ & $<0.001$ & $<0.001$ & $<0.001$ & $<0.01$ \\
\hline & & $07 / 14 / 92$ & $<0.001$ & $<0.001$ & $<0.01$ & $<0.1$ & $<0.01$ & $<0.001$ & $<0.001$ & $<0.001$ & $<0.01$ \\
\hline \multirow[t]{3}{*}{ PRW } & Potholes Reservoir, & $11 / 19 / 91$ & $<0.001$ & $<0.001$ & $<0.01$ & $<0.1$ & $<0.01$ & $<0.001$ & $<0.001$ & $<0.001$ & $<0.01$ \\
\hline & west arm & $0.3 / 0.3 / 92$ & $<0.001$ & $<0.001$ & $<0.01$ & $<0.1$ & $<0.01$ & $<0.001$ & $<0.001$ & $<0.001$ & $<0.01$ \\
\hline & & $07 / 15 / 92$ & $<0.001$ & $<0.001$ & $<0.01$ & $<0.1$ & $<0.01$ & $<0.001$ & $<0.001$ & $<0.001$ & $<0.01$ \\
\hline PRE & $\begin{array}{l}\text { Potholes Reservoir, } \\
\text { east arm }\end{array}$ & $07 / 15 / 92$ & $<0.001$ & $<0.001$ & $<0.01$ & $<0.1$ & $<0.01$ & $<0.001$ & $<0.001$ & $<0.001$ & $<0.01$ \\
\hline \multirow[t]{3}{*}{ WW } & Winchester & $11 / 18 / 91$ & $<0.001$ & $<0.001$ & $<0.01$ & $<0.1$ & $<0.01$ & $<0.001$ & $<0.001$ & $<0.001$ & $<0.01$ \\
\hline & Wasteway & $03 / 02 / 92$ & $<0.001$ & $<0.001$ & $<0.01$ & $<0.1$ & $<0.01$ & $<0.001$ & $<0.001$ & $<0.001$ & $<0.01$ \\
\hline & & $07 / 15 / 92$ & $<0.001$ & $<0.001$ & $<0,01$ & $<0.1$ & $<0.01$ & $<0.001$ & $<0.001$ & $<0.001$ & $<0.01$ \\
\hline \multirow[t]{3}{*}{ FHW } & Frenchman Hills & $11 / 21 / 91$ & $<0.001$ & $<0.001$ & $<0.01$ & $<0.1$ & $<0.01$ & $<0.001$ & $<0.001$ & $<0.001$ & $<0.01$ \\
\hline & Wasteway & $03 / 03 / 92$ & $<0.001$ & $<0.001$ & $<0.01$ & $<0.1$ & $<0.01$ & $<0.001$ & $<0.001$ & $<0.001$ & $<0.01$ \\
\hline & & $07 / 15 / 92$ & $<0.001$ & $<0.001$ & $<0.01$ & $<0.1$ & $<0.01$ & $<0.001$ & $<0.001$ & $<0.001$ & $<0.01$ \\
\hline \multirow[t]{3}{*}{$\mathbf{L C W}$} & Lind Coulee & $11 / 18 / 91$ & $<0.001$ & $<0.001$ & $<0.01$ & $<0.1$ & $<0.01$ & $<0.001$ & $<0.001$ & $<0.001$ & $<0.01$ \\
\hline & Wasteway & $03 / 02 / 92$ & $<0.001$ & $<0.001$ & $<0.01$ & $<0.1$ & $<0.01$ & $<0.001$ & $<0.001$ & $<0.001$ & $<0.01$ \\
\hline & & $07 / 14 / 92$ & $<0.001$ & $<0.001$ & $<0.01$ & $<0.1$ & $<0.01$ & $<0.001$ & $<0.001$ & $<0.001$ & $<0.01$ \\
\hline \multirow[t]{3}{*}{ SL } & Soda Lake & $11 / 20 / 91$ & $<0.001$ & $<0.001$ & $<0.01$ & $<0.1$ & $<0.01$ & $<0.001$ & $<0.001$ & $<0.001$ & $<0.01$ \\
\hline & & $03 / 04 / 92$ & $<0.001$ & $<0.001$ & $<0.01$ & $<0.1$ & $<0.01$ & $<0.001$ & $<0.001$ & $<0.001$ & $<0.01$ \\
\hline & & $07 / 17 / 92$ & $<0.001$ & $<0.001$ & $<0.01$ & $<0.1$ & $<0.01$ & $<0.001$ & $<0.001$ & $<0.001$ & $<0.01$ \\
\hline $\mathrm{CCM}$ & $\begin{array}{l}\text { Lower Crab Creek, } \\
\text { McManamon Road }\end{array}$ & $07 / 15 / 92$ & $<0.001$ & $<0.001$ & $<0.01$ & $<0.1$ & $<0.01$ & $<0.001$ & $<0.001$ & $<0.001$ & 0.03 \\
\hline LGL & Lower Goose Lake & $07 / 17 / 92$ & $<0.001$ & $<0.001$ & $<0.01$ & $<0.1$ & $<0.01$ & $<0.001$ & $<0.001$ & $<0.001$ & $<0.01$ \\
\hline $\mathrm{SHCb}$ & $\begin{array}{l}\text { Sand Hollow Creek } \\
\text { at mouth }\end{array}$ & $11 / 20 / 91$ & $<0.001$ & $<0.001$ & $<0.01$ & $<0.1$ & $<0.01$ & $<0.001$ & $<0.001$ & $<0.001$ & $<0.01$ \\
\hline \multirow[t]{2}{*}{$\mathrm{SHCa}$} & Sand Hollow Creek & $03 / 04 / 92$ & $<0.001$ & $<0.001$ & $<0.01$ & $<0.1$ & $<0.01$ & $<0.001$ & $<0.001$ & $<0.001$ & $<0.01$ \\
\hline & at Road S, SW & $07 / 16 / 92$ & $<0.001$ & $<0.001$ & $<0.01$ & $<0.1$ & $<0.01$ & $<0.001$ & $<0.001$ & $<0.001$ & $<0.01$ \\
\hline \multirow[t]{3}{*}{$\mathrm{CCB}$} & Crab Creek near & $11 / 21 / 91$ & $<0.001$ & $<0.001$ & $<0.01$ & $<0.1$ & $<0.01$ & $<0.001$ & $<0.001$ & $<0.001$ & $<0.01$ \\
\hline & Beverly & $03 / 05 / 92$ & $<0.001$ & $<0.001$ & $<0.01$ & $<0.1$ & $<0.01$ & $<0.001$ & $<0.001$ & $<0.001$ & $<0.01$ \\
\hline & & $07 / 16 / 92$ & $<0.001$ & $<0.001$ & $<0.01$ & $<0.1$ & $<0.01$ & $<0.001$ & $<0.001$ & $<0.001$ & $<0.01$ \\
\hline SMW & $\begin{array}{l}\text { Saddle Mountain } \\
\text { Wasteway }\end{array}$ & $07 / 17 / 92$ & $<0.001$ & $<0.001$ & $<0.01$ & $<0.1$ & $<0.01$ & $<0.001$ & $<0.001$ & $<0.001$ & $<0.01$ \\
\hline
\end{tabular}


Table 26.--Results of analyses for insecticides, herbicides, and other organic compounds in whole wcter samples from the Columbia Basin Project. November 1991, March 1992, and July 1992--Continued

\begin{tabular}{|c|c|c|c|c|c|c|c|c|c|c|c|}
\hline $\begin{array}{l}\text { Map } \\
\text { identi- } \\
\text { fier } \\
\text { (fig. 9) }\end{array}$ & Station name & Date & $\begin{array}{l}\text { Endo- } \\
\text { sulfan } \\
(\mu \mathrm{g} / \mathrm{L})\end{array}$ & $\begin{array}{l}\text { Endrin } \\
(\mu g / L)\end{array}$ & $\begin{array}{l}\text { Ethion } \\
(\mu \mathrm{g} / \mathrm{L})\end{array}$ & $\begin{array}{l}\text { Ethylan } \\
\text { (Per- } \\
\text { thane) } \\
(\mu \mathrm{g} / \mathrm{L})\end{array}$ & $\begin{array}{l}\text { Fono- } \\
\text { fos } \\
(\mu g / L)\end{array}$ & $\begin{array}{l}\text { Hepta- } \\
\text { chlor } \\
(\mu \mathrm{g} / \mathrm{L})\end{array}$ & $\begin{array}{l}\text { Hepta- } \\
\text { chlor } \\
\text { epo- } \\
\text { xide } \\
(\mu g / L)\end{array}$ & $\begin{array}{l}\text { Lindane } \\
(\mu \mathrm{g} / \mathrm{L})\end{array}$ & $\begin{array}{l}\text { Mala- } \\
\text { thion } \\
(\mu \mathrm{g} / \mathrm{L})\end{array}$ \\
\hline \multirow[t]{3}{*}{ ELW } & EL68D Wasteway & $11 / 19 / 91$ & $<0.001$ & $<0.001$ & $<0.01$ & $<0.1$ & $<0.01$ & $<0.001$ & $<0.001$ & $<0.001$ & $<0.01$ \\
\hline & & $03 / 04 / 92$ & $<0.001$ & $<0.001$ & $<0.01$ & $<0.1$ & $<0.01$ & $<0.001$ & $<0.001$ & $<0.001$ & $<0.01$ \\
\hline & & $07 / 14 / 92$ & $<0.001$ & $<0.001$ & $<0.01$ & $<0.1$ & $<0.01$ & $<0.001$ & $<0.001$ & 0.001 & $<0.01$ \\
\hline \multirow[t]{3}{*}{ WBWa } & Wahluke Branch & $11 / 19 / 91$ & $<0.001$ & $<0.001$ & $<0.01$ & $<0.1$ & $<0.01$ & $<0.001$ & $<0.001$ & $<0.001$ & $<0.01$ \\
\hline & 10A Wasteway & $03 / 04 / 92$ & $<0.001$ & $<0.001$ & $<0.01$ & $<0.1$ & $<0.01$ & $<0.001$ & $<0.001$ & $<0.001$ & $<0.01$ \\
\hline & & $07 / 17 / 92$ & $<0.001$ & $<0.001$ & $<0.01$ & $<0.1$ & $<0.01$ & $<0.001$ & $<0.001$ & $<0.001$ & $<0.01$ \\
\hline \multirow[t]{3}{*}{ PEW } & PE16.4 Wasteway & $11 / 20 / 91$ & $<0.001$ & $<0.001$ & $<0.01$ & $<0.1$ & $<0.01$ & $<0.001$ & $<0.001$ & $<0.001$ & $<0.01$ \\
\hline & & $03 / 03 / 92$ & $<0.001$ & $<0.001$ & $<0.01$ & $<0.1$ & $<0.01$ & $<0.001$ & $<0.001$ & $<0.001$ & $<0.01$ \\
\hline & & $07 / 16 / 92$ & $<0.001$ & $<0.001$ & $<0.01$ & $<0.1$ & $<0.01$ & $<0.001$ & $<0.001$ & $<0.001$ & $<0.01$ \\
\hline \multirow[t]{4}{*}{$\mathrm{ECW}$} & Esquatzel Coulee & $11 / 20 / 91$ & $<0.001$ & $<0.001$ & $<0.01$ & $<0.1$ & $<0.01$ & $<0.001$ & $<0.001$ & $<0.001$ & $<0.01$ \\
\hline & Wasteway & $03 / 03 / 92$ & $<0.001$ & $<0.001$ & $<0.01$ & $<0.1$ & $<0.01$ & $<0.001$ & $<0.001$ & $<0.001$ & $<0.01$ \\
\hline & & $07 / 16 / 92$ & $<0.001$ & $<0.001$ & $<0.01$ & $<0.1$ & $<0.01$ & $<0.001$ & $<0.001$ & $<0.001$ & $<0.01$ \\
\hline & \multicolumn{11}{|c|}{ Duplicate Samples } \\
\hline $\mathrm{SHCb}$ & $\begin{array}{l}\text { Sand Hollow Creek } \\
\text { at mouth }\end{array}$ & $11 / 20 / 91$ & $<0.001$ & $<0.001$ & $<0.01$ & $<0.1$ & $<0.01$ & $<0.001$ & $<0.001$ & $<0.001$ & $<0.01$ \\
\hline PRW & $\begin{array}{l}\text { Potholes Reservoir, } \\
\text { west arm }\end{array}$ & $03 / 03 / 92$ & $<0.001$ & $<0.001$ & $<0.01$ & $<0.1$ & $<0.01$ & $<0.001$ & $<0.001$ & $<0.001$ & $<0.01$ \\
\hline PRE & $\begin{array}{l}\text { Potholes Reservoir, } \\
\text { east arm }\end{array}$ & $07 / 15 / 92$ & $<0.001$ & $<0.001$ & $<0.01$ & $<0.1$ & $<0.01$ & $<0.001$ & $<0.001$ & $<0.001$ & $<0.01$ \\
\hline WW & $\begin{array}{l}\text { Winchester } \\
\text { Wasteway }\end{array}$ & $07 / 15 / 92$ & $<0.001$ & $<0.001$ & $<0.01$ & $<0.1$ & $<0.01$ & $<0.001$ & $<0.001$ & $<0.001$ & $<0.01$ \\
\hline
\end{tabular}


Table 26.--Results of analyses for insecticides, herbicides, and other organic compounds in whole water samples from the Columbia Basin Project, November 1991, March 1992, and July 1992--Continued

\begin{tabular}{|c|c|c|c|c|c|c|c|c|c|c|c|}
\hline $\begin{array}{l}\text { Map } \\
\text { identi- } \\
\text { fier } \\
\text { (fig. 9) }\end{array}$ & Station name & Date & $\begin{array}{l}\text { Meth- } \\
\text { oxy- } \\
\text { chlor } \\
(\mu g / L)\end{array}$ & $\begin{array}{l}\text { Methyl } \\
\text { para- } \\
\text { thion } \\
(\mu g / L)\end{array}$ & $\begin{array}{l}\text { Mirex } \\
(\mu g / L)\end{array}$ & $\begin{array}{l}\text { Para- } \\
\text { thion } \\
(\mu g / L)\end{array}$ & $\begin{array}{l}\text { Pho- } \\
\text { rate } \\
(\mu g / L)\end{array}$ & $\begin{array}{l}\text { Toxa- } \\
\text { phene } \\
(\mu g / L)\end{array}$ & $\begin{array}{l}\text { Tri- } \\
\text { thion } \\
(\mu g / L)\end{array}$ & $\begin{array}{l}2,4-D \\
(\mu g / L)\end{array}$ & $\begin{array}{l}2,4,5-T \\
(\mu g / L)\end{array}$ \\
\hline \multirow[t]{3}{*}{$\mathrm{BCl}$} & \multirow[t]{3}{*}{ Billy Clapp Lake } & $11 / 18 / 91$ & $<0.01$ & $<0.01$ & $<0.01$ & $<0.01$ & $<0.01$ & $<1$ & $<0.01$ & $<0.01$ & $<0.01$ \\
\hline & & 03/02/92 & $<0.01$ & $<0.01$ & $<0.01$ & $<0.01$ & $<0.01$ & $<1$ & $<0.01$ & $<0.01$ & $<0.01$ \\
\hline & & $07 / 13 / 92$ & $<0.01$ & $<0.01$ & $<0.01$ & $<0.01$ & $<0.01$ & $<1$ & $<0.01$ & 0.02 & $<0.01$ \\
\hline \multirow[t]{3}{*}{ RFC } & \multirow[t]{3}{*}{ Rocky Ford Creek } & $11 / 18 / 91$ & $<0.01$ & $<0.01$ & $<0.01$ & $<0.01$ & $<0.01$ & $<1$ & $<0.01$ & 0.03 & $<0.01$ \\
\hline & & 03/02/92 & $<0.01$ & $<0.01$ & $<0.01$ & $<0.01$ & $<0.01$ & $<1$ & $<0.01$ & $<0.01$ & $<0.01$ \\
\hline & & $07 / 13 / 92$ & $<0.01$ & $<0.01$ & $<0.01$ & $<0.01$ & $<0.01$ & $<1$ & $<0.01$ & $<0.01$ & $<0.01$ \\
\hline $\mathrm{CCU}$ & Upper Crab Creek & $07 / 14 / 92$ & $<0.01$ & $<0.01$ & $<0.01$ & $<0.01$ & $<0.01$ & $<1$ & $<0.01$ & $<0.01$ & $<0.01$ \\
\hline \multirow[t]{3}{*}{ MLR } & \multirow{3}{*}{$\begin{array}{l}\text { Moses Lake, } \\
\text { Rocky Ford arm }\end{array}$} & $11 / 18 / 91$ & $<0.01$ & $<0.01$ & $<0.01$ & $<0.01$ & $<0.01$ & $<1$ & $<0.01$ & $<0.01$ & $<0.01$ \\
\hline & & $03 / 02 / 92$ & $<0.01$ & $<0.01$ & $<0.01$ & $<0.01$ & $<0.01$ & $<1$ & $<0.01$ & $<0.01$ & $<0.01$ \\
\hline & & $07 / 14 / 92$ & $<0.01$ & $<0.01$ & $<0.01$ & $<0.01$ & $<0.01$ & $<1$ & $<0.01$ & 0.04 & $<0.01$ \\
\hline MLP & $\begin{array}{l}\text { Moses Lake, } \\
\text { Parker Horn arm }\end{array}$ & $07 / 14 / 92$ & $<0.01$ & $<0.01$ & $<0.01$ & $<0.01$ & $<0.01$ & $<1$ & $<0.01$ & 0.11 & $<0.01$ \\
\hline \multirow[t]{3}{*}{ MLS } & Moses Lake, & $11 / 19 / 91$ & $<0.01$ & $<0.01$ & $<0.01$ & $<0.01$ & $<0.01$ & $<1$ & $<0.01$ & $<0.01$ & $<0.01$ \\
\hline & \multirow[t]{2}{*}{ south end } & $03 / 03 / 92$ & $<0.01$ & $<0.01$ & $<0.01$ & $<0.01$ & $<0.01$ & $<1$ & $<0.01$ & $<0.01$ & $<0.01$ \\
\hline & & $07 / 14 / 92$ & $<0.01$ & $<0.01$ & $<0.01$ & $<0.01$ & $<0.01$ & $<1$ & $<0.01$ & - & -- \\
\hline \multirow[t]{3}{*}{ PRW } & \multirow{3}{*}{$\begin{array}{l}\text { Potholes Reservoir, } \\
\text { west arm }\end{array}$} & $|1 / 19 / 9|$ & $<0.01$ & $<0.01$ & $<0.01$ & $<0.01$ & $<0.01$ & $<1$ & $<0.01$ & $<0.01$ & $<0.01$ \\
\hline & & $03 / 03 / 92$ & $<0.01$ & $<0.01$ & $<0.01$ & $<0.01$ & $<0.01$ & $<1$ & $<0.01$ & $<0.01$ & $<0.01$ \\
\hline & & $07 / 15 / 92$ & $<0.01$ & $<0.01$ & $<0.01$ & $<0.01$ & $<0.01$ & $<1$ & $<0.01$ & 0.04 & $<0.01$ \\
\hline PRE & $\begin{array}{l}\text { Potholes Reservoir, } \\
\text { east arm }\end{array}$ & $07 / 15 / 92$ & $<0.01$ & 0.01 & $<0.01$ & $<0.01$ & $<0.01$ & $<1$ & $<0.01$ & 0.04 & $<0.01$ \\
\hline \multirow[t]{3}{*}{ Ww } & Winchester & $11 / 18 / 91$ & $<0.01$ & $<0.01$ & $<0.01$ & $<0.01$ & $<0.01$ & $<1$ & $<0.01$ & 0.01 & $<0.01$ \\
\hline & Wasteway & $03 / 02 / 92$ & $<0.01$ & $<0.01$ & $<0.01$ & $<0.01$ & $<0.01$ & $<1$ & $<0.01$ & $<0.01$ & $<0.01$ \\
\hline & & $07 / 15 / 92$ & $<0.01$ & $<0.01$ & $<0.01$ & $<0.01$ & $<0.01$ & $<1$ & $<0.01$ & $<0.01$ & $<0.01$ \\
\hline \multirow[t]{3}{*}{ FHW } & Frenchman Hills & $11 / 21 / 91$ & $<0.01$ & $<0.01$ & $<0.01$ & $<0.01$ & $<0.01$ & $<1$ & $<0.01$ & 0.05 & $<0.01$ \\
\hline & Wasteway & $03 / 03 / 92$ & $<0.01$ & $<0.01$ & $<0.01$ & $<0.01$ & $<0.01$ & $<1$ & $<0.01$ & $<0.01$ & $<0.01$ \\
\hline & & $07 / 15 / 92$ & $<0.01$ & $<0.01$ & $<0.01$ & $<0.01$ & $<0.01$ & $<1$ & $<0.01$ & 0.04 & $<0.01$ \\
\hline \multirow[t]{3}{*}{ LCW } & Lind Coulee & $11 / 18 / 91$ & $<0.01$ & $<0.01$ & $<0.01$ & $<0.01$ & $<0.01$ & $<1$ & $<0.01$ & 0.11 & $<0.01$ \\
\hline & Wasteway & $03 / 02 / 92$ & $<0.01$ & $<0.01$ & $<0.01$ & $<0.01$ & $<0.01$ & $<1$ & $<0.01$ & $<0.01$ & $<0.01$ \\
\hline & & $07 / 14 / 92$ & $<0.01$ & $<0.01$ & $<0.01$ & $<0.01$ & $<0.01$ & $<1$ & $<0.01$ & 0.04 & $<0.01$ \\
\hline \multirow[t]{3}{*}{ SL } & Soda Lake & $11 / 20 / 91$ & $<0.01$ & $<0.01$ & $<0.01$ & $<0.01$ & $<0.01$ & $<1$ & $<0.01$ & 0.07 & $<0.01$ \\
\hline & & $03 / 04 / 92$ & $<0.01$ & $<0.01$ & $<0.01$ & $<0.01$ & $<0.01$ & $<1$ & $<0.01$ & $<0.01$ & $<0.01$ \\
\hline & & $07 / 17 / 92$ & $<0.01$ & $<0.01$ & $<0.01$ & $<0.01$ & $<0.01$ & $<1$ & $<0.01$ & 0.03 & $<0.01$ \\
\hline $\mathrm{CCM}$ & $\begin{array}{l}\text { Lower Crab Creek, } \\
\text { McManamon Road }\end{array}$ & $07 / 15 / 92$ & 0.07 & $<0.01$ & $<0.01$ & $<0.01$ & $<0.01$ & $<1$ & $<0.01$ & 0.06 & $<0.01$ \\
\hline LGL & Lower Goose Lake & $07 / 17 / 92$ & $<0.01$ & 0.01 & $<0.01$ & $<0.01$ & $<0.01$ & $<1$ & $<0.01$ & 0.04 & $<0.01$ \\
\hline $\mathrm{SHCb}$ & $\begin{array}{l}\text { Sand Hollow Creek } \\
\text { at mouth }\end{array}$ & $11 / 20 / 91$ & $<0.01$ & $<0.01$ & $<0.01$ & $<0.01$ & $<0.01$ & $<1$ & $<0.01$ & $<0.01$ & $<0.01$ \\
\hline \multirow[t]{2}{*}{$\mathrm{SHCa}$} & Sand Hollow Creek & $03 / 04 / 92$ & $<0.01$ & $<0.01$ & $<0.01$ & $<0.01$ & $<0.01$ & $<1$ & $<0.01$ & $<0.01$ & $<0.01$ \\
\hline & at Road S, SW & $07 / 16 / 92$ & $<0.01$ & $<0.01$ & $<0.01$ & $<0.01$ & $<0.01$ & $<1$ & $<0.01$ & 0.08 & $<0.01$ \\
\hline \multirow[t]{3}{*}{ CCB } & Crab Creek near & $11 / 21 / 91$ & $<0.01$ & $<0.01$ & $<0.01$ & $<0.01$ & $<0.01$ & $<1$ & $<0.01$ & 0.02 & $<0.01$ \\
\hline & Beverly & $03 / 05 / 92$ & $<0.01$ & $<0.01$ & $<0.01$ & $<0.01$ & $<0.01$ & $<1$ & $<0.01$ & $<0.01$ & $<0.01$ \\
\hline & & $07 / 16 / 92$ & $<0.01$ & $<0.01$ & $<0.01$ & $<0.01$ & $<0.01$ & $<1$ & $<0.01$ & 0.10 & $<0.01$ \\
\hline SMW & $\begin{array}{l}\text { Saddle Mountain } \\
\text { Wasteway }\end{array}$ & $07 / 17 / 92$ & $<0.01$ & $<0.01$ & $<0.01$ & $<0.01$ & $<0.01$ & $<1$ & $<0.01$ & 0.16 & $<0.01$ \\
\hline
\end{tabular}


Table 26. --Results of analyses for insecticides, herbicides, and other organic compounds in whole water samples from the Columbia Basin Project, November 1991, March 1992, and July 1992--Continued

\begin{tabular}{|c|c|c|c|c|c|c|c|c|c|c|c|}
\hline $\begin{array}{l}\text { Map } \\
\text { identi- } \\
\text { fier } \\
\text { (fig. 9) }\end{array}$ & Station name & Date & $\begin{array}{l}\text { Meth- } \\
\text { oxy- } \\
\text { chlor } \\
(\mu g / L)\end{array}$ & $\begin{array}{l}\text { Methyl } \\
\text { para- } \\
\text { thion } \\
(\mu g / L)\end{array}$ & $\begin{array}{l}\text { Mirex } \\
(\mu g / L)\end{array}$ & $\begin{array}{l}\text { Para- } \\
\text { thion } \\
(\mu g / L)\end{array}$ & $\begin{array}{l}\text { Pho- } \\
\text { rate } \\
(\mu g / L)\end{array}$ & $\begin{array}{l}\text { Toxa- } \\
\text { phene } \\
(\mu g / L)\end{array}$ & $\begin{array}{l}\text { Tri- } \\
\text { thion } \\
(\mu g / L)\end{array}$ & $\begin{array}{l}2,4-D \\
(\mu g / L)\end{array}$ & $\begin{array}{l}2,4,5-T \\
(\mu g / L)\end{array}$ \\
\hline \multirow[t]{3}{*}{ ELW } & EL68D Wasteway & $11 / 19 / 91$ & $<0.01$ & $<0.01$ & $<0.01$ & $<0.01$ & $<0.01$ & $<1$ & $<0.01$ & 0.17 & $<0.01$ \\
\hline & & $03 / 04 / 92$ & $<0.01$ & $<0.01$ & $<0.01$ & $<0.01$ & $<0.01$ & $<1$ & $<0.01$ & $<0.01$ & $<0.01$ \\
\hline & & $07 / 14 / 92$ & $<0.01$ & 0.01 & $<0.01$ & $<0.01$ & $<0.01$ & $<1$ & $<0.01$ & 0.16 & $<0.01$ \\
\hline \multirow[t]{3}{*}{ WBWa } & Wahluke Branch & $11 / 19 / 91$ & $<0.01$ & $<0.01$ & $<0.01$ & $<0.01$ & $<0.01$ & $<1$ & $<0.01$ & $<0.01$ & $<0.01$ \\
\hline & 10A Wasteway & $03 / 04 / 92$ & $<0.01$ & $<0.01$ & $<0.01$ & $<0.01$ & $<0.01$ & $<1$ & $<0.01$ & $<0.01$ & $<0.01$ \\
\hline & & $07 / 17 / 92$ & $<0.01$ & $<0.01$ & $<0.01$ & $<0.01$ & $<0.01$ & $<1$ & $<0.01$ & 0.22 & $<0.01$ \\
\hline \multirow[t]{3}{*}{ PEW } & PE16.4 Wasteway & $11 / 20 / 91$ & $<0.01$ & $<0.01$ & $<0.01$ & $<0.01$ & $<0.01$ & $<1$ & $<0.01$ & 1.0 & $<0.01$ \\
\hline & & $03 / 03 / 92$ & $<0.01$ & $<0.01$ & $<0.01$ & $<0.01$ & $<0.01$ & $<1$ & $<0.01$ & $<0.01$ & $<0.01$ \\
\hline & & $07 / 16 / 92$ & $<0.01$ & $<0.01$ & $<0.01$ & $<0.01$ & $<0.01$ & $<1$ & $<0.01$ & 0.07 & $<0.01$ \\
\hline \multirow[t]{4}{*}{$\mathrm{ECW}$} & Esquatzel Coulee & $11 / 20 / 91$ & $<0.01$ & $<0.01$ & $<0.01$ & $<0.01$ & $<0.01$ & $<1$ & $<0.01$ & 0.50 & $<0.01$ \\
\hline & Wasteway & $03 / 03 / 92$ & $<0.01$ & $<0.01$ & $<0.01$ & $<0.01$ & $<0.01$ & $<1$ & $<0.01$ & $<0.01$ & $<0.01$ \\
\hline & & $07 / 16 / 92$ & $<0.01$ & $<0.01$ & $<0.01$ & $<0.01$ & $<0.01$ & $<1$ & $<0.01$ & 0.04 & $<0.01$ \\
\hline & \multicolumn{11}{|c|}{ Duplicate Samples } \\
\hline $\mathrm{SHCb}$ & $\begin{array}{l}\text { Sand Hollow Creek } \\
\text { at mouth }\end{array}$ & $11 / 20 / 91$ & $<0.01$ & $<0.01$ & $<0.01$ & $<0.01$ & $<0.01$ & $<1$ & $<0.01$ & 0.05 & $<0.01$ \\
\hline PRW & $\begin{array}{l}\text { Potholes Reservoir, } \\
\text { west arm }\end{array}$ & $03 / 03 / 92$ & $<0.01$ & $<0.01$ & $<0.01$ & $<0.01$ & $<0.01$ & $<1$ & $<0.01$ & $<0.01$ & $<0.01$ \\
\hline PRE & $\begin{array}{l}\text { Potholes Reservoir, } \\
\text { east arm }\end{array}$ & $07 / 15 / 92$ & $<0.01$ & $<0.01$ & $<0.01$ & $<0.01$ & $<0.01$ & $<1$ & $<0.01$ & 0.04 & $<0.01$ \\
\hline WW & $\begin{array}{l}\text { Winchester } \\
\text { Wasteway }\end{array}$ & $07 / 15 / 92$ & $<0.01$ & $<0.01$ & $<0.01$ & $<0.01$ & $<0.01$ & $<1$ & $<0.01$ & 0.01 & $<0.01$ \\
\hline
\end{tabular}


Table 26.--Results of analyses for insecticides, herbicides, and other organic compounds in whole water samples from the Columbia Basin Project, November 1991, March 1992, and July 1992--Continued

\begin{tabular}{|c|c|c|c|c|c|c|c|c|c|}
\hline $\begin{array}{l}\text { Map } \\
\text { identi- } \\
\text { fier } \\
\text { (fig. 9) }\end{array}$ & Station name & Date & $\begin{array}{l}\text { 2,4-DP } \\
(\mu g / L)\end{array}$ & $\begin{array}{l}\text { Dicamba } \\
(\mu g / L)\end{array}$ & $\begin{array}{l}\text { Piclo- } \\
\text { ram } \\
(\mu \mathrm{g} / \mathrm{L})\end{array}$ & $\begin{array}{l}\mathrm{DEF} \\
(\mu g / L)\end{array}$ & $\begin{array}{l}\text { Silvex } \\
(\mu g / L)\end{array}$ & $\begin{array}{l}\text { PCB } \\
(\mu g L)\end{array}$ & $\begin{array}{l}\text { PCN } \\
(\mu g / L)\end{array}$ \\
\hline \multirow[t]{3}{*}{ BCL } & \multirow[t]{3}{*}{ Billy Clapp Lake } & $11 / 18 / 91$ & $<0.01$ & $<0.01$ & $<0.01$ & $<0.01$ & $<0.01$ & $<01$ & $<0.10$ \\
\hline & & $03 / 02 / 92$ & $<0.01$ & $<0.01$ & $<0.01$ & $<0.01$ & $<0.01$ & $<01$ & $<0.10$ \\
\hline & & $07 / 13 / 92$ & $<0.01$ & $<0.01$ & $<0.01$ & $<0.01$ & $<0.01$ & $<01$ & $<0.10$ \\
\hline \multirow[t]{3}{*}{ RFC } & \multirow[t]{3}{*}{ Rocky Ford Creek } & $11 / 18 / 91$ & $<0.01$ & $<0.01$ & $<0.01$ & $<0.01$ & $<0.01$ & $<01$ & $<0.10$ \\
\hline & & $03 / 02 / 92$ & $<0.01$ & $<0.01$ & $<0.01$ & $<0.01$ & $<0.01$ & $<01$ & $<0.10$ \\
\hline & & $07 / 13 / 92$ & $<0.01$ & $<0.01$ & $<0.01$ & $<0.01$ & $<0.01$ & $<01$ & $<0.10$ \\
\hline $\mathrm{CCU}$ & Upper Crab Creek & $07 / 14 / 92$ & $<0.01$ & $<0.01$ & $<0.01$ & $<0.01$ & $<0.01$ & $<01$ & $<0.10$ \\
\hline \multirow[t]{3}{*}{ MLR } & \multirow{3}{*}{$\begin{array}{l}\text { Moses Lake, } \\
\text { Rocky Ford arm }\end{array}$} & $11 / 18 / 91$ & $<0.01$ & $<0.01$ & $<0.01$ & $<0.01$ & $<0.01$ & $<01$ & $<0.10$ \\
\hline & & $03 / 02 / 92$ & $<0.01$ & $<0.01$ & $<0.01$ & $<0.01$ & $<0.01$ & $<01$ & $<0.10$ \\
\hline & & $07 / 14 / 92$ & $<0.01$ & $<0.01$ & $<0.01$ & $<0.01$ & $<0.01$ & $<01$ & $<0.10$ \\
\hline MLP & $\begin{array}{l}\text { Moses Lake, } \\
\text { Parker Horn arm }\end{array}$ & $07 / 14 / 92$ & $<0.01$ & 0.02 & $<0.01$ & $<0.01$ & $<0.01$ & $<0.1$ & $<0.10$ \\
\hline \multirow[t]{3}{*}{ MLS } & \multirow{3}{*}{$\begin{array}{l}\text { Moses Lake, } \\
\text { south end }\end{array}$} & $11 / 19 / 91$ & $<0.01$ & $<0.01$ & $<0.01$ & $<0.01$ & $<0.01$ & $<0.1$ & $<0.10$ \\
\hline & & $03 / 03 / 92$ & $<0.01$ & $<0.01$ & $<0.01$ & $<0.01$ & $<0.01$ & $<0.1$ & $<0.10$ \\
\hline & & $07 / 14 / 92$ & -- & -- & -. & $<0.01$ & $\ldots$ & $<0.1$ & $<0.10$ \\
\hline \multirow[t]{3}{*}{ PRW } & \multirow{3}{*}{$\begin{array}{l}\text { Potholes Reservoir, } \\
\text { west arm }\end{array}$} & $11 / 19 / 91$ & $<0.01$ & $<0.01$ & $<0.01$ & $<0.01$ & $<0.01$ & $<0.1$ & $<0.10$ \\
\hline & & $03 / 03 / 92$ & $<0.01$ & $<0.01$ & $<0.01$ & $<0.01$ & $<0.01$ & $<0.1$ & $<0.10$ \\
\hline & & $07 / 15 / 92$ & $<0.01$ & $<0.01$ & $<0.01$ & $<0.01$ & $<0.01$ & $<0.1$ & $<0.10$ \\
\hline PRE & $\begin{array}{l}\text { Potholes Reservoir, } \\
\text { east arm }\end{array}$ & $07 / 15 / 92$ & $<0.01$ & $<0.01$ & $<0.01$ & $<0.01$ & $<0.01$ & $<0.1$ & $<0.10$ \\
\hline \multirow[t]{3}{*}{ Ww } & Winchester & $11 / 18 / 91$ & $<0.01$ & $<0.01$ & $<0.01$ & $<0.01$ & $<0.01$ & $<0.1$ & $<0.10$ \\
\hline & Wasteway & $03 / 02 / 92$ & $<0.01$ & $<0.01$ & 0.02 & $<0.01$ & $<0.01$ & $<0.1$ & $<0.10$ \\
\hline & & $07 / 15 / 92$ & $<0.01$ & $<0.01$ & $<0.01$ & $<0.01$ & $<0.01$ & $<0.1$ & $<0.10$ \\
\hline \multirow[t]{3}{*}{ FHW } & Prenchman Hills & $11 / 21 / 91$ & $<0.01$ & $<0.01$ & $<0.01$ & $<0.01$ & $<0.01$ & $<0.1$ & $<0.10$ \\
\hline & Wasteway & $03 / 03 / 92$ & $<0.01$ & $<0.01$ & $<0.01$ & $<0.01$ & $<0.01$ & $<0.1$ & $<0.10$ \\
\hline & & $07 / 15 / 92$ & $<0.01$ & $<0.01$ & $<0.01$ & $<0.01$ & $<0.01$ & $<0.1$ & $<0.10$ \\
\hline \multirow[t]{3}{*}{ LCW } & Lind Coulee & $11 / 18 / 91$ & $<0.01$ & $<0.01$ & $<0.01$ & $<0.01$ & $<0.01$ & $<0.1$ & $<0.10$ \\
\hline & Wasteway & $03 / 02 / 92$ & $<0.01$ & $<0.01$ & $<0.01$ & $<0.01$ & $<0.01$ & $<0.1$ & $<0.10$ \\
\hline & & $07 / 14 / 92$ & $<0.01$ & $<0.01$ & $<0.01$ & $<0.01$ & $<0.01$ & $<0.1$ & $<0.10$ \\
\hline \multirow[t]{3}{*}{ SL } & Soda Lake & $11 / 20 / 91$ & $<0.01$ & $<0.01$ & $<0.01$ & $<0.01$ & $<0.01$ & $<0.1$ & $<0.10$ \\
\hline & & $03 / 04 / 92$ & $<0.01$ & $<0.01$ & $<0.01$ & $<0.01$ & $<0.01$ & $<0.1$ & $<0.10$ \\
\hline & & $07 / 17 / 92$ & $<0.01$ & $<0.01$ & $<0.01$ & $<0.01$ & $<0.01$ & $<0.1$ & $<0.10$ \\
\hline $\mathrm{CCM}$ & $\begin{array}{l}\text { Lower Crab Creek, } \\
\text { McManamon Road }\end{array}$ & $07 / 15 / 92$ & $<0.01$ & $<0.01$ & $<0.01$ & $<0.01$ & $<0.01$ & $<0.1$ & $<0.10$ \\
\hline LGL & Lower Goose Lake & $07 / 17 / 92$ & $<0.01$ & $<0.01$ & $<0.01$ & $<0.01$ & $<0.01$ & $<0.1$ & $<0.10$ \\
\hline SHCb & $\begin{array}{l}\text { Sand Hollow Creek } \\
\text { at mouth }\end{array}$ & $11 / 20 / 91$ & $<0.01$ & $<0.01$ & $<0.01$ & $<0.01$ & $<0.01$ & $<0.1$ & $<0.10$ \\
\hline \multirow[t]{2}{*}{ SHCa } & Sand Hollow Creek & $03 / 04 / 92$ & $<0.01$ & $<0.01$ & $<0.01$ & $<0.01$ & $<0.01$ & $<0.1$ & $<0.10$ \\
\hline & at Road S, SW & $07 / 16 / 92$ & $<0.01$ & $<0.01$ & $<0.01$ & $<0.01$ & $<0.01$ & $<0.1$ & $<0.10$ \\
\hline \multirow[t]{3}{*}{$\mathrm{CCB}$} & Crab Creek near & $11 / 21 / 91$ & $<0.01$ & $<0.01$ & $<0.01$ & $<0.01$ & $<0.01$ & $<0.1$ & $<0.10$ \\
\hline & Beverly & $03 / 05 / 92$ & $<0.01$ & $<0.01$ & $<0.01$ & $<0.01$ & $<0.01$ & $<0.1$ & $<0.10$ \\
\hline & & $07 / 16 / 92$ & $<0.01$ & $<0.01$ & $<0.01$ & $<0.01$ & $<0.01$ & $<0.1$ & $<0.10$ \\
\hline SMW & $\begin{array}{l}\text { Saddle Mountain } \\
\text { Wasteway }\end{array}$ & $07 / 17 / 92$ & $<0.01$ & 1.0 & $<0.01$ & $<0.01$ & $<0.01$ & $<0.1$ & $<0.10$ \\
\hline
\end{tabular}


Table 26.--Results of analyses for insecticides, herbicides, and other organic compounds in whole water samples from the Columbia Basin Project, November 1991, March 1992, and July 1992--Continued

\begin{tabular}{|c|c|c|c|c|c|c|c|c|c|}
\hline $\begin{array}{l}\text { Map } \\
\text { identi- } \\
\text { fier } \\
\text { (fig. 9) }\end{array}$ & Station name & Date & $\begin{array}{l}2,4-D P \\
(\mu g / L)\end{array}$ & $\begin{array}{l}\text { Dicamba } \\
(\mu g / L)\end{array}$ & $\begin{array}{l}\text { Piclo- } \\
\text { ram } \\
(\mu g / L)\end{array}$ & $\begin{array}{l}\text { DEF } \\
(\mu g / L)\end{array}$ & $\begin{array}{l}\text { Silvex } \\
(\mu g / L)\end{array}$ & $\begin{array}{l}\text { PCB } \\
(' \mathrm{H} / \mathrm{L})\end{array}$ & $\begin{array}{l}\text { PCN } \\
(\mu \mathrm{g} / \mathrm{L})\end{array}$ \\
\hline \multirow[t]{3}{*}{ ELW } & EL68D Wasteway & $11 / 19 / 91$ & $<0.01$ & $<0.01$ & $<0.01$ & $<0.01$ & $<0.01$ & $<0.1$ & $<0.10$ \\
\hline & & $03 / 04 / 92$ & $<0.01$ & $<0.01$ & $<0.01$ & $<0.01$ & $<0.01$ & $<0.1$ & $<0.10$ \\
\hline & & $07 / 14 / 92$ & $<0.01$ & $<0.01$ & $<0.01$ & $<0.01$ & $<0.01$ & $<0.1$ & $<0.10$ \\
\hline \multirow[t]{3}{*}{ WBWa } & Wahluke Branch & $11 / 19 / 91$ & $<0.01$ & $<0.01$ & $<0.01$ & $<0.01$ & $<0.01$ & $<0.1$ & $<0.10$ \\
\hline & 10A Wasteway & $03 / 04 / 92$ & $<0.01$ & 0.01 & $<0.01$ & $<0.01$ & $<0.01$ & $<0.1$ & $<0.10$ \\
\hline & & $07 / 17 / 92$ & $<0.01$ & 0.01 & $<0.01$ & $<0.01$ & $<0.01$ & $<0.1$ & $<0.10$ \\
\hline \multirow[t]{3}{*}{ PEW } & PE16.4 Wasteway & $11 / 20 / 91$ & $<0.01$ & $<0.01$ & $<0.01$ & $<0.01$ & $<0.01$ & $<0.1$ & $<0.10$ \\
\hline & & $03 / 03 / 92$ & $<0.01$ & $<0.01$ & $<0.01$ & $<0.01$ & $<0.01$ & $<0.1$ & $<0.10$ \\
\hline & & $07 / 16 / 92$ & $<0.01$ & $<0.01$ & $<0.01$ & $<0.01$ & $<0.01$ & $<0.1$ & $<0.10$ \\
\hline \multirow[t]{4}{*}{$\mathrm{ECW}$} & Esquatzel Coulee & $11 / 20 / 91$ & $<0.01$ & $<0.01$ & $<0.01$ & $<0.01$ & $<0.01$ & $<0.1$ & $<0.10$ \\
\hline & Wasteway & $03 / 03 / 92$ & $<0.01$ & $<0.01$ & $<0.01$ & $<0.01$ & $<0.01$ & $<0.1$ & $<0.10$ \\
\hline & & $07 / 16 / 92$ & $<0,01$ & $<0.01$ & $<0.01$ & $<0.01$ & $<0.01$ & $<0.1$ & $<0.10$ \\
\hline & \multicolumn{9}{|c|}{ Duplicate Samples } \\
\hline $\mathrm{SHCb}$ & $\begin{array}{l}\text { Sand Hollow Creek } \\
\text { at mouth }\end{array}$ & $11 / 20 / 91$ & $<0.01$ & $<0.01$ & $<0.01$ & $<0.01$ & $<0.01$ & $<0.1$ & $<0.10$ \\
\hline PRW & $\begin{array}{l}\text { Potholes Reservoir, } \\
\text { west arm }\end{array}$ & 03/03/92 & $<0.01$ & $<0.01$ & $<0.01$ & $<0.01$ & $<0.01$ & $<0.1$ & $<0.10$ \\
\hline PRE & $\begin{array}{l}\text { Potholes Reservoir, } \\
\text { east arm }\end{array}$ & 07/15/92 & $<0.01$ & $<0.01$ & $<0.01$ & $<0.01$ & $<0.01$ & $<0.1$ & $<0.10$ \\
\hline Ww & $\begin{array}{l}\text { Winchester } \\
\text { Wasteway }\end{array}$ & 07/15/92 & $<0.01$ & $<0.01$ & $<0.01$ & $<0.01$ & $<0.01$ & $<0.1$ & $<0.10$ \\
\hline
\end{tabular}


Table 27. --Results of analyses for total trace elements and carbon in the less-than-2-millimeter size fraction of bottomsediment samples from the Columbia Basin Project, July 1992

[\%-Wt = percent by weight; $\mu \mathrm{g} / \mathrm{g}=$ micrograms per gram; <, less than $]$

\begin{tabular}{|c|c|c|c|c|c|c|c|c|c|c|}
\hline $\begin{array}{l}\text { Map } \\
\text { identi- } \\
\text { fier } \\
\text { (fig. 9) }\end{array}$ & Station name & Date & $\begin{array}{l}\text { Alum- } \\
\text { inum } \\
(\%-W t)\end{array}$ & $\begin{array}{l}\text { Arsenic } \\
(\mu g / g)\end{array}$ & $\begin{array}{l}\text { Barium } \\
(\mu g / g)\end{array}$ & $\begin{array}{l}\text { Beryllium } \\
(\mu g / g)\end{array}$ & $\begin{array}{l}\text { Bismuth } \\
(\mu g / g)\end{array}$ & $\begin{array}{l}\text { Boron } \\
(\mu g / g)\end{array}$ & $\begin{array}{l}\text { Cal- } \\
\text { cium } \\
(\%-W t)\end{array}$ & $\begin{array}{l}\text { Cad- } \\
\text { mium } \\
(\mu g / g)\end{array}$ \\
\hline BCL & Billy Clapp Lake & $07 / 13 / 92$ & 6.8 & 6.7 & 720 & 2 & $<10$ & 0.3 & 2.3 & $<2$ \\
\hline RFC & Rocky Ford Creek & $07 / 13 / 92$ & 2.3 & 5.2 & 190 & $<1$ & $<10$ & 1.0 & 2.2 & $<2$ \\
\hline $\mathrm{CCU}$ & Upper Crab Creek & $07 / 14 / 92$ & 3.3 & 3.6 & 310 & $<1$ & $<10$ & 0.9 & 15.0 & $<2$ \\
\hline MLR & $\begin{array}{l}\text { Moses Lake, } \\
\text { Rocky Ford arm }\end{array}$ & $07 / 14 / 92$ & 7.0 & 3.1 & 510 & 1 & $<10$ & 0.5 & 4.6 & $<$ \\
\hline MLP & $\begin{array}{l}\text { Moses Lake, } \\
\text { Parker Horn arm }\end{array}$ & $07 / 14 / 92$ & 6.3 & 3.6 & 460 & 1 & $<10$ & 0.5 & 8.5 & $<2$ \\
\hline MLS & $\begin{array}{l}\text { Moses Lake, } \\
\text { south end }\end{array}$ & $07 / 14 / 92$ & 5.7 & 4.1 & 380 & 1 & $<10$ & 0.4 & 8.1 & $<2$ \\
\hline PRW & $\begin{array}{l}\text { Potholes Reservoir, } \\
\text { west arm }\end{array}$ & $07 / 15 / 92$ & 6.2 & 4.5 & 550 & 1 & $<10$ & 0.3 & 6.4 & $<2$ \\
\hline PRE & $\begin{array}{l}\text { Potholes Reservoir, } \\
\text { east arm }\end{array}$ & $07 / 16 / 92$ & 6.5 & 3.0 & 570 & 2 & $<10$ & 0.3 & 4.0 & 2 \\
\hline WW & $\begin{array}{l}\text { Winchester } \\
\text { Wasteway }\end{array}$ & $07 / 15 / 92$ & 4.6 & 11 & 420 & 1 & $<10$ & 0.6 & 11.0 & $<2$ \\
\hline FHW & $\begin{array}{l}\text { Frenchman Hills } \\
\text { Wasteway }\end{array}$ & $07 / 15 / 92$ & 6.6 & 8.5 & 560 & 2 & $<10$ & 0.3 & 4.3 & $<2$ \\
\hline $\mathrm{LCW}$ & Lind Coulee Wasteway & $07 / 14 / 92$ & 7.4 & 9.4 & 600 & 2 & $<10$ & 0.4 & 2.9 & $<2$ \\
\hline SL & Soda Lake & $07 / 17 / 92$ & 7.4 & 4.9 & 530 & 2 & $<10$ & 0.3 & 3.4 & $<2$ \\
\hline $\mathrm{CCM}$ & $\begin{array}{l}\text { Lower Crab Creek, } \\
\text { McManamon Road }\end{array}$ & $07 / 15 / 92$ & 5.8 & 8.1 & 530 & 2 & $<10$ & 0.9 & 3.9 & $<2$ \\
\hline LGL & Lower Goose Lake & $07 / 17 / 92$ & 7.1 & 4.0 & 600 & 2 & $<10$ & $<0.2$ & 2.4 & $<2$ \\
\hline $\mathrm{SHCb}$ & $\begin{array}{l}\text { Sand Hollow Creek } \\
\text { at mouth }\end{array}$ & $07 / 16 / 92$ & 6.9 & 4.1 & 620 & 2 & $<10$ & 0.5 & 3.5 & $<2$ \\
\hline CCB & $\begin{array}{l}\text { Crab Creek near } \\
\text { Beverly }\end{array}$ & $07 / 16 / 92$ & 5.7 & 4.8 & 630 & 1 & $<10$ & 0.6 & 6.9 & $<2$ \\
\hline SMW & $\begin{array}{l}\text { Saddle Mountain } \\
\text { Wasteway }\end{array}$ & $07 / 17 / 92$ & 6.9 & 3.4 & 760 & 2 & $<10$ & 0.2 & 2.8 & $<2$ \\
\hline ELW & EL68D Wasteway & $07 / 15 / 92$ & 7.1 & 3.8 & 630 & 2 & $<10$ & 0.4 & 2.1 & $<2$ \\
\hline WBWb & $\begin{array}{l}\text { Wahluke Branch } \\
\text { Wasteway Lake }\end{array}$ & $07 / 17 / 92$ & 6.3 & 6.4 & 590 & 2 & $<10$ & 0.5 & 5.3 & $<2$ \\
\hline PEW & PE16.4 Wasteway & $07 / 16 / 92$ & 6.9 & 4.6 & 710 & 2 & $<10$ & 0.2 & 3.1 & $<2$ \\
\hline ECW & $\begin{array}{l}\text { Esquatzel Coulee } \\
\text { Wasteway }\end{array}$ & $07 / 16 / 92$ & 6.7 & 5.5 & 610 & 2 & $<10$ & 0.3 & 2.9 & $<$ \\
\hline \multicolumn{11}{|c|}{ Duplicate Sample } \\
\hline PRW & $\begin{array}{l}\text { Potholes Reservoir, } \\
\text { west arm }\end{array}$ & $07 / 15 / 92$ & 5.6 & 3.8 & 450 & 1 & $<10$ & 0.5 & 7.7 & $<2$ \\
\hline
\end{tabular}


Table 27.--Results of analyses for total trace elements and carbon in the less-than-2-millimeter size frcrtion of bottomsediment samples from the Columbia Basin Project, July 1992--Continued

\begin{tabular}{|c|c|c|c|c|c|c|c|c|c|c|}
\hline $\begin{array}{l}\text { Map } \\
\text { identi- } \\
\text { fier } \\
\text { (fig. 9) }\end{array}$ & Station name & Date & $\begin{array}{l}\text { Cerium } \\
(\mu g / g)\end{array}$ & $\begin{array}{l}\text { Chro- } \\
\text { mium } \\
(\mu g / g)\end{array}$ & $\begin{array}{l}\text { Cobalt } \\
(\mu g / g)\end{array}$ & $\begin{array}{l}\text { Copper } \\
(\mu g / g)\end{array}$ & $\begin{array}{l}\text { Euro- } \\
\text { pium } \\
(\mu g / g)\end{array}$ & $\begin{array}{l}\text { Gal- } \\
\text { lium } \\
(\mu g / g)\end{array}$ & $\begin{array}{l}\text { Grold } \\
(\mid \mathrm{Lg} / \mathrm{g})\end{array}$ & $\begin{array}{l}\text { Iron } \\
(\%-W t)\end{array}$ \\
\hline $\mathrm{BCL}$ & Billy Clapp Lake & $07 / 13 / 92$ & 66 & 30 & 15 & 15 & 2 & 17 & $<8$ & 4.0 \\
\hline RFC & Rocky Ford Creek & $07 / 13 / 92$ & 13 & 11 & 3.0 & 21 & 2 & 5.0 & $<8$ & 0.95 \\
\hline $\mathrm{CCU}$ & Upper Crab Creek & $07 / 1492$ & 16 & 12 & 7.0 & 19 & $<2$ & 8.0 & $<8$ & 1.6 \\
\hline MLR & $\begin{array}{l}\text { Moses Lake, } \\
\text { Rocky Ford arm }\end{array}$ & $07 / 14992$ & 39 & 30 & 15 & 20 & $<$ & 16 & $<8$ & 3.8 \\
\hline MLP & $\begin{array}{l}\text { Moses Lake, } \\
\text { Parker Horn arm }\end{array}$ & $07 / 1492$ & 34 & 22 & 13 & 32 & $<2$ & 14 & $<8$ & 2.9 \\
\hline MLS & $\begin{array}{l}\text { Moses Lake, } \\
\text { south end }\end{array}$ & $07 / 1492$ & 28 & 19 & 9.0 & 32 & $<$ & 13 & $<8$ & 2.6 \\
\hline PRW & $\begin{array}{l}\text { Potholes Reservoir, } \\
\text { west arm }\end{array}$ & $07 / 15 / 92$ & 36 & 23 & 19 & 19 & $<2$ & 16 & $<8$ & 4.7 \\
\hline PRE & $\begin{array}{l}\text { Potholes Reservoir, } \\
\text { east arm }\end{array}$ & $07 / 16 / 92$ & 44 & 23 & 17 & 19 & 2 & 16 & $<8$ & 4.6 \\
\hline ww & $\begin{array}{l}\text { Winchester } \\
\text { Wasteway }\end{array}$ & $07 / 15 / 92$ & 30 & 19 & 12 & 22 & $<2$ & 11 & $<8$ & 3.0 \\
\hline FHW & $\begin{array}{l}\text { Frenchman Hills } \\
\text { Wasteway }\end{array}$ & $07 / 15 / 92$ & 45 & 34 & 20 & 26 & 2 & 17 & $<8$ & 5.0 \\
\hline LCW & Lind Coulee Wasteway & $07 / 14 / 92$ & 54 & 41 & 19 & 43 & 2 & 19 & $<8$ & 4.7 \\
\hline SL & Soda Lake & $07 / 17 / 92$ & 48 & 35 & 21 & 24 & $<$ & 19 & $<8$ & 4.8 \\
\hline CCM & $\begin{array}{l}\text { Lower Crab Creck, } \\
\text { McManamon Road }\end{array}$ & $07 / 15 / 92$ & 46 & 34 & 19 & 20 & 2 & 18 & $<8$ & 4.9 \\
\hline LGL & Lower Goose Lake & $07 / 17 / 92$ & $\$ 9$ & 38 & 16 & 20 & 2 & 16 & $<8$ & 3.8 \\
\hline $\mathrm{SHCb}$ & $\begin{array}{l}\text { Sand Hollow Creek } \\
\text { at mouth }\end{array}$ & $07 / 16 / 92$ & 57 & 47 & 17 & 29 & 2 & 16 & $<8$ & 3.9 \\
\hline CCB & $\begin{array}{l}\text { Crab Creek near } \\
\text { Beverly }\end{array}$ & $07 / 16 \times 92$ & 41 & 36 & 13 & 21 & 2 & 15 & $<8$ & 3.0 \\
\hline SMW & $\begin{array}{l}\text { Saddle Mountain } \\
\text { Wasteway }\end{array}$ & $07 / 17 / 92$ & $\mathbf{s 2}$ & 45 & 13 & 12 & 2 & 14 & $<8$ & 3.2 \\
\hline ELW & El68D Wasteway & $07 / 15 / 92$ & 57 & 48 & 15 & 28 & 2 & 16 & $<8$ & 3.8 \\
\hline WBWb & $\begin{array}{l}\text { Wahluke Branch } \\
\text { Wasteway Lake }\end{array}$ & $07 / 17 / 92$ & 44 & 36 & 16 & 16 & $<2$ & 16 & $<8$ & 4.0 \\
\hline PEW & PE16.4 Wasteway & $07 / 16 \times 92$ & 58 & 46 & 15 & 16 & 2 & 16 & $<8$ & 4.0 \\
\hline ECW & $\begin{array}{l}\text { Esquatzel Coulec } \\
\text { Wasteway }\end{array}$ & $07 / 16 / 92$ & 58 & 42 & 16 & 18 & $<$ & 16 & $<8$ & 4.2 \\
\hline
\end{tabular}

\section{Duplicente Somple}

$\begin{array}{llllllllll}\text { PRW Potholes Reservoir, } & 07 / 15 / 92 & 32 & 20 & 15 & 22 & < & 14 & <8\end{array}$


Table 27.--Results of analyses for total trace elements and carbon in the less-than-2-millimeter size fraition of bottomsediment samples from the Columbia Basin Project, July 1992.-Continued

\begin{tabular}{|c|c|c|c|c|c|c|c|c|c|c|}
\hline $\begin{array}{l}\text { Map } \\
\text { identi- } \\
\text { fier } \\
\text { (fig. 9) }\end{array}$ & Station name & Date & $\begin{array}{l}\text { Lanth- } \\
\text { anum } \\
(\mu g / g)\end{array}$ & $\begin{array}{l}\text { Lead } \\
(\mu g / g)\end{array}$ & $\begin{array}{l}\text { Lithium } \\
(\mu g / 8)\end{array}$ & $\begin{array}{l}\text { Magne- } \\
\text { sium } \\
(\$-W t)\end{array}$ & $\begin{array}{l}\text { Manga- } \\
\text { nese } \\
(\mu g / g)\end{array}$ & $\begin{array}{l}\text { Mercury } \\
(\mu g / g)\end{array}$ & $\begin{array}{l}\text { Molyb- } \\
\text { denum } \\
\text { (y } / 8 \text { ) }\end{array}$ & $\begin{array}{l}\text { Neody- } \\
\text { mium } \\
(\mu g / g)\end{array}$ \\
\hline BCL & Billy Clapp Lake & $07 / 13 / 92$ & 34 & 15 & 25 & 1.3 & 710 & $<0.02$ & $\alpha$ & 32 \\
\hline RFC & Rocky Ford Croek & $07 / 13 / 92$ & 7.0 & 6 & 7.0 & 0.50 & 150 & $<0.02$ & 3 & 7.0 \\
\hline $\mathrm{CCU}$ & Upper Crab Creek & $07 / 14 / 92$ & 9.0 & $\mathbf{5}$ & 12 & 0.92 & 530 & $<0.02$ & $\alpha$ & 11 \\
\hline MLR & $\begin{array}{l}\text { Moses Lake, } \\
\text { Rocky Ford arm }\end{array}$ & $07 / 14 / 92$ & 22 & 10 & 21 & 1.4 & 560 & 0.02 & 2 & 23 \\
\hline MLP & $\begin{array}{l}\text { Moses Lake, } \\
\text { Parker Horn arm }\end{array}$ & $07 / 14 / 92$ & 18 & 11 & 20 & 1.2 & 430 & 0.03 & 2 & 18 \\
\hline MLS & $\begin{array}{l}\text { Moses Lake, } \\
\text { south end }\end{array}$ & $07 / 14 / 92$ & 15 & 12 & 25 & 0.96 & 520 & 0.03 & $\alpha$ & 16 \\
\hline PRW & $\begin{array}{l}\text { Potholes Reservoir, } \\
\text { west arm }\end{array}$ & $07 / 15 / 92$ & 20 & 7 & 15 & 1.4 & 850 & $<0.02$ & 2 & 22 \\
\hline PRE & $\begin{array}{l}\text { Potholes Reservoir, } \\
\text { east arm }\end{array}$ & $07 / 16 / 92$ & 23 & 10 & 18 & 1.3 & 790 & $<0.02$ & 2 & 25 \\
\hline WW & $\begin{array}{l}\text { Winchester } \\
\text { Wasteway }\end{array}$ & $07 / 15 / 92$ & 16 & 10 & 16 & 1.1 & 550 & $<0.02$ & $\Omega$ & 19 \\
\hline FHW & $\begin{array}{l}\text { Frenchman Hills } \\
\text { Wasteway }\end{array}$ & $07 / 15 / 92$ & 24 & 13 & 21 & 1.4 & 820 & 0.03 & 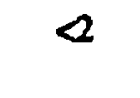 & 25 \\
\hline LCW & Lind Coulee Wasteway & $07 / 14 / 92$ & 28 & 18 & 34 & 1.3 & 780 & 0.02 & $\alpha$ & 28 \\
\hline SL & Soda Lake & $07 / 17 / 92$ & 25 & 10 & 23 & 1.4 & 730 & 0.02 & 2 & 24 \\
\hline $\mathrm{CCM}$ & $\begin{array}{l}\text { Lower Crab Creek, } \\
\text { McManamon Road }\end{array}$ & $07 / 15 / 92$ & 24 & 9 & 20 & 1.5 & 2,800 & 0.02 & 2 & 24 \\
\hline LGL & Lower Goose Lake & $07 / 17 / 92$ & 30 & 12 & 22 & 1.1 & 580 & 0.02 & $\Omega$ & 29 \\
\hline $\mathrm{SHCb}$ & $\begin{array}{l}\text { Sand Hollow Creek } \\
\text { at mouth }\end{array}$ & $07 / 16 / 92$ & 31 & 14 & 23 & 1.3 & 600 & 0.02 & $\alpha$ & 28 \\
\hline $\mathrm{CCB}$ & $\begin{array}{l}\text { Crab Creek near } \\
\text { Beverly }\end{array}$ & $07 / 16 / 92$ & 23 & 10 & 23 & 2.0 & 750 & 0.02 & $\alpha$ & 23 \\
\hline SMW & $\begin{array}{l}\text { Saddle Mountain } \\
\text { Wasteway }\end{array}$ & $07 / 17 / 92$ & 28 & 14 & 20 & 1.1 & 490 & $<0.02$ & $\Omega$ & 23 \\
\hline ELW & EL68D Wasteway & $07 / 15 / 92$ & 31 & 17 & 28 & 1.2 & 530 & $<0.02$ & $\Omega$ & 29 \\
\hline WBWb & $\begin{array}{l}\text { Wahluke Branch } \\
\text { Wasteway Lake }\end{array}$ & $07 / 17 / 92$ & 23 & 11 & 19 & 1.2 & 790 & $<0.02$ & $\alpha$ & 24 \\
\hline PEW & PE16.4 Wasteway & $07 / 16 / 92$ & 31 & 14 & 22 & 1.3 & 660 & $<0.02$ & $\alpha$ & 28 \\
\hline $\mathrm{ECW}$ & $\begin{array}{l}\text { Esquatzel Coulee } \\
\text { Wasteway }\end{array}$ & $07 / 16 / 92$ & 30 & 14 & 23 & 1.3 & 660 & $<0.02$ & $<$ & 30 \\
\hline \multicolumn{11}{|c|}{ Durilicete Samole } \\
\hline PRW & $\begin{array}{l}\text { Potholes Reservoir, } \\
\text { west arm }\end{array}$ & $07 / 15 / 92$ & 17 & 7 & 14 & 1.2 & 690 & $<0.02$ & $a$ & 19 \\
\hline
\end{tabular}


Table 27.--Results of analyses for total trace elements and carbon in the less-than-2-millimeter size fraction of bottomsediment samples from the Columbia Basin Project, July 1992--Continued

\begin{tabular}{|c|c|c|c|c|c|c|c|c|c|c|}
\hline $\begin{array}{l}\text { Map } \\
\text { identi- } \\
\text { fier } \\
\text { (fig. 9) }\end{array}$ & Station name & Date & $\begin{array}{l}\text { Nickel } \\
(\mu g / g)\end{array}$ & $\begin{array}{l}\text { Niobium } \\
(\mu g / g)\end{array}$ & $\begin{array}{l}\text { Phos- } \\
\text { phorus } \\
(\%-W t)\end{array}$ & $\begin{array}{l}\text { Potas- } \\
\text { sium } \\
\left(q_{0}-W t\right)\end{array}$ & $\begin{array}{l}\text { Scan- } \\
\text { dium } \\
(\mu g / g)\end{array}$ & $\begin{array}{l}\text { Sele- } \\
\text { nium } \\
(\mu g / g)\end{array}$ & $\begin{array}{l}\text { Silver } \\
(\mu g / g)\end{array}$ & $\begin{array}{l}\text { Sodium } \\
\left(\left(\phi_{0}-W t\right)\right.\end{array}$ \\
\hline BCL & Billy Clapp Lake & $07 / 13 / 92$ & 14 & 5.0 & 0.09 & 2.3 & 15 & $<0.1$ & $<$ & 1.6 \\
\hline RFC & Rocky Ford Crcek & $07 / 13 / 92$ & 6 & $<4$ & 0.12 & 0.45 & 3.0 & 4.1 & $<$ & 0.80 \\
\hline $\mathrm{CCU}$ & Upper Crab Creek & $07 / 14 / 92$ & 8 & $<4$ & 0.17 & 0.71 & 6.0 & 0.3 & $<2$ & 1.0 \\
\hline MLR & $\begin{array}{l}\text { Moses Lake, } \\
\text { Rocky Ford arm }\end{array}$ & $07 / 14 / 92$ & 12 & 8.0 & 0.12 & 1.5 & 14 & 0.5 & $<$ & 2.1 \\
\hline MLP & $\begin{array}{l}\text { Moses Lake, } \\
\text { Parker Horn arm }\end{array}$ & $07 / 14 / 92$ & 12 & 5.0 & 0.11 & 1.2 & 10 & 0.4 & $<$ & 2.0 \\
\hline MLS & $\begin{array}{l}\text { Moses Lake, } \\
\text { south end }\end{array}$ & $07 / 14 / 92$ & 12 & 5.0 & 0.10 & 1.1 & 9.0 & 0.4 & $<$ & 1.6 \\
\hline PRW & $\begin{array}{l}\text { Potholes Reservoir, } \\
\text { west arm }\end{array}$ & $07 / 15 / 92$ & 11 & $<4$ & 0.10 & 1.4 & 17 & 0.7 & $<$ & 1.9 \\
\hline PRE & $\begin{array}{l}\text { Potholes Reservoir, } \\
\text { east arm }\end{array}$ & $07 / 16 / 92$ & 10 & 4.0 & 0.10 & 1.6 & 17 & 0.2 & $<$ & 1.9 \\
\hline WW & $\begin{array}{l}\text { Winchester } \\
\text { Wasteway }\end{array}$ & $07 / 15 / 92$ & 10 & 6.0 & 0.13 & 1.1 & 10 & 1.1 & $<2$ & 1.3 \\
\hline FHW & $\begin{array}{l}\text { Frenchman Hills } \\
\text { Wasteway }\end{array}$ & $07 / 15 / 92$ & 16 & 6.0 & 0.11 & 1.5 & 17 & 0.5 & $<2$ & 1.8 \\
\hline $\mathrm{LCW}$ & Lind Coulee Wasteway & $07 / 14 / 92$ & 22 & 9.0 & 0.13 & 1.8 & 15 & 0.3 & $<$ & 1.6 \\
\hline SL & Soda Lake & $07 / 17 / 92$ & 17 & 8.0 & 0.11 & 1.5 & 16 & 0.3 & $<2$ & 2.1 \\
\hline $\mathrm{CCM}$ & $\begin{array}{l}\text { Lower Crab Creek, } \\
\text { McManamon Road }\end{array}$ & $07 / 15 / 92$ & 15 & 4.0 & 0.12 & 1.4 & 14 & 0.5 & $<2$ & 1.5 \\
\hline LGL & Lower Goose Lake & $07 / 17 / 92$ & 18 & 6.0 & 0.09 & 1.7 & 14 & $<0.1$ & $<2$ & 2.0 \\
\hline $\mathrm{SHCb}$ & $\begin{array}{l}\text { Sand Hollow Creek } \\
\text { at mouth }\end{array}$ & $07 / 16 / 92$ & 22 & 10 & 0.11 & 1.6 & 14 & 0.3 & $<2$ & 1.8 \\
\hline $\mathrm{CCB}$ & $\begin{array}{l}\text { Crab Creek near } \\
\text { Beverly }\end{array}$ & $07 / 16 / 92$ & 17 & 7.0 & 0.12 & 1.5 & 10 & 0.5 & $<$ & 1.6 \\
\hline SMW & $\begin{array}{l}\text { Saddle Mountain } \\
\text { Wasteway }\end{array}$ & $07 / 17 / 92$ & 17 & 5.0 & 0.07 & 2.0 & 11 & 0.1 & $<$ & 2.1 \\
\hline ELW & EL68D Wasteway & $07 / 15 / 92$ & 23 & 11 & 0.09 & 1.8 & 13 & 0.2 & $<2$ & 1.6 \\
\hline WBWb & $\begin{array}{l}\text { Wahluke Branch } \\
\text { Wasteway Lake }\end{array}$ & $07 / 17 / 92$ & 17 & $<4$ & 0.08 & 1.6 & 14 & 0.4 & $<2$ & 1.7 \\
\hline PEW & PE16.4 Wasteway & $07 / 16 / 92$ & 18 & 4.0 & 0.08 & 1.9 & 14 & 0.2 & $<2$ & 2.0 \\
\hline $\mathrm{ECW}$ & $\begin{array}{l}\text { Esquatzel Coulec } \\
\text { Wasteway }\end{array}$ & $07 / 16 / 92$ & 18 & 6.0 & 0.10 & 1.8 & 14 & 0.1 & $<2$ & 1.7 \\
\hline \multicolumn{11}{|c|}{ Duplicate Sample } \\
\hline PRW & $\begin{array}{l}\text { Potholes Reservoir, } \\
\text { west arm }\end{array}$ & $07 / 15 / 92$ & 9.0 & $<4$ & 0.13 & 1.2 & 13 & 1.1 & $<$ & 1.8 \\
\hline
\end{tabular}


Table 27.--Results of analyses for total trace elements and carbon in the less-than-2-millimeter size fraction of bottomsediment samples from the Columbia Basin Project, July 1992--Continued

\begin{tabular}{|c|c|c|c|c|c|c|c|c|c|c|}
\hline $\begin{array}{l}\text { Map } \\
\text { identi- } \\
\text { fier } \\
\text { (fig. 9) }\end{array}$ & Station name & Date & $\begin{array}{l}\text { Stron- } \\
\text { tium } \\
(\mu g / g)\end{array}$ & $\begin{array}{l}\text { Tant- } \\
\text { alum } \\
(\mu g / g)\end{array}$ & $\begin{array}{l}\text { Thor- } \\
\text { ium } \\
(\mu \mathrm{g} / \mathrm{g})\end{array}$ & $\begin{array}{l}\text { Tin } \\
(\mu g / g)\end{array}$ & $\begin{array}{l}\text { Tita- } \\
\text { nium } \\
(\%-W t)\end{array}$ & $\begin{array}{l}\text { Ura- } \\
\text { nium } \\
(\mu g / g)\end{array}$ & $\begin{array}{l}\text { Vana- } \\
\text { dium } \\
(\mu \mathrm{g} / \mathrm{g})\end{array}$ & $\begin{array}{l}\text { Ytter- } \\
\text { bium } \\
(\mu \mathrm{g} / \mathrm{g})\end{array}$ \\
\hline $\mathrm{BCL}$ & Billy Clapp Lake & $07 / 13 / 92$ & 310 & $<40$ & 8.3 & $<5$ & 0.51 & 2.4 & 130 & 2.0 \\
\hline RFC & Rocky Ford Creek & $07 / 13 / 92$ & 180 & $<40$ & $<6$ & $<5$ & 0.13 & 8.0 & 120 & $<1$ \\
\hline $\mathrm{CCU}$ & Upper Crab Creek & $07 / 14 / 92$ & 590 & $<40$ & $<3$ & $<5$ & 0.20 & 1.8 & 52 & $<1$ \\
\hline MLR & $\begin{array}{l}\text { Moses Lake, } \\
\text { Rocky Ford arm }\end{array}$ & $07 / 14 / 92$ & 410 & $<40$ & 5.2 & $<5$ & 0.58 & 2.1 & 130 & 2.0 \\
\hline MLP & $\begin{array}{l}\text { Moses Lake, } \\
\text { Parker Horn arm }\end{array}$ & $07 / 14 / 92$ & 500 & $<40$ & 3.6 & $<5$ & 0.39 & 1.9 & 89 & 2.0 \\
\hline MLS & $\begin{array}{l}\text { Moses Lake, } \\
\text { south end }\end{array}$ & $07 / 14 / 92$ & 340 & $<40$ & 4.4 & $<5$ & 0.28 & 2.3 & 74 & 2.0 \\
\hline PRW & $\begin{array}{l}\text { Potholes Reservoir, } \\
\text { west arm }\end{array}$ & $07 / 15 / 92$ & 410 & $<40$ & 4.0 & $\boldsymbol{\sigma}$ & 0.55 & 1.9 & 180 & 2.0 \\
\hline PRE & $\begin{array}{l}\text { Potholes Reservoir, } \\
\text { east arm }\end{array}$ & $07 / 16 / 92$ & 340 & $<40$ & 5.3 & $<5$ & 0.57 & 1.8 & 160 & 3.0 \\
\hline wW & $\begin{array}{l}\text { Winchester } \\
\text { Wasteway }\end{array}$ & $07 / 15 / 92$ & 440 & $<40$ & 3.4 & $\infty$ & 0.38 & 2.2 & 110 & 1.0 \\
\hline FHW & $\begin{array}{l}\text { Frenchman Hills } \\
\text { Wasteway }\end{array}$ & $07 / 15 / 92$ & 350 & $<40$ & 7.4 & $\boldsymbol{5}$ & 0.61 & 2.4 & 160 & 2.0 \\
\hline $\mathrm{LCW}$ & Lind Coulee Wasteway & $07 / 14 / 92$ & 250 & $<40$ & 7.0 & $\infty$ & 0.56 & 2.5 & 120 & 2.0 \\
\hline SL & Soda Lake & $07 / 17 / 92$ & 410 & $<40$ & 6.8 & $<5$ & 0.67 & 2.7 & 170 & 2.0 \\
\hline $\mathrm{CCM}$ & $\begin{array}{l}\text { Lower Crab Creek, } \\
\text { McManamon Road }\end{array}$ & $07 / 15 / 92$ & 330 & $<40$ & 7.2 & $<5$ & 0.58 & 2.3 & 140 & 2.0 \\
\hline LGL & Lower Goose Lake & $07 / 17 / 92$ & 370 & $<40$ & 7.1 & $<5$ & 0.50 & 2.3 & 110 & 2.0 \\
\hline $\mathrm{SHCb}$ & $\begin{array}{l}\text { Sand Hollow Creek } \\
\text { at mouth }\end{array}$ & $07 / 16 / 92$ & 380 & $<40$ & 9.8 & $\infty$ & 0.50 & 2.6 & 120 & 2.0 \\
\hline CCB & $\begin{array}{l}\text { Crab Creek near } \\
\text { Beverly }\end{array}$ & $07 / 16 / 92$ & 520 & $<40$ & 6.6 & $<5$ & 0.37 & 2.1 & 87 & 1.0 \\
\hline SMW & $\begin{array}{l}\text { Saddle Mountain } \\
\text { Wasteway }\end{array}$ & $07 / 17 / 92$ & 450 & $<40$ & 7.2 & $<5$ & 0.40 & 2.5 & 100 & 2.0 \\
\hline ELW & EL68D Wasteway & $07 / 15 / 92$ & 320 & $<40$ & 10 & $<5$ & 0.47 & 3.2 & 110 & 2.0 \\
\hline WBWb & $\begin{array}{l}\text { Wahluke Branch } \\
\text { Wasteway Lake }\end{array}$ & $07 / 17 / 92$ & 420 & $<40$ & 7.2 & $\infty$ & 0.50 & 2.6 & 130 & 2.0 \\
\hline PEW & PE16.4 Wasteway & $07 / 16 / 92$ & 410 & $<40$ & 9.4 & $<5$ & 0.51 & 2.5 & 130 & 2.0 \\
\hline ECW & $\begin{array}{l}\text { Esquatzel Coulee } \\
\text { Wasteway }\end{array}$ & $07 / 16 / 92$ & 340 & $<40$ & 8.6 & $<$ & 0.57 & 2.7 & 130 & 2.0 \\
\hline \multicolumn{11}{|c|}{ Duplicate Samote } \\
\hline PRW & $\begin{array}{l}\text { Potholes Reservoir, } \\
\text { west arm }\end{array}$ & $07 / 15 / 92$ & 420 & $<40$ & $<$ & $<5$ & 0.49 & 2.1 & 140 & 2.0 \\
\hline
\end{tabular}


Table 27.--Results of analyses for total trace elements and carbon in the less-than-2-millimeter size fraction of bottomsediment samples from the Columbia Basin Project, July 1992--Continued

\begin{tabular}{|c|c|c|c|c|c|c|}
\hline $\begin{array}{l}\text { Map } \\
\text { identi- } \\
\text { fier } \\
\text { (fig. 9) }\end{array}$ & Station name & Date & $\begin{array}{l}\text { Ytt- } \\
\text { rium } \\
(\mu g / g)\end{array}$ & $\begin{array}{l}\text { Zinc } \\
(\mu g / g)\end{array}$ & $\begin{array}{l}\text { Total } \\
\text { Corbon } \\
(g, W t)\end{array}$ & $\begin{array}{l}\text { Organic } \\
\text { Carbon } \\
(\%-W t)\end{array}$ \\
\hline $\mathrm{BCL}$ & Billy Clapp Lake & $07 / 13 / 92$ & 19 & 65 & 0.13 & 0.05 \\
\hline RFC & Rocky Ford Creek & $07 / 13 / 92$ & 5.0 & 35 & 16 & 16 \\
\hline $\mathrm{CCU}$ & Upper Crab Creek & $07 / 14192$ & 7.0 & 32 & 8.3 & 4.4 \\
\hline MLR & $\begin{array}{l}\text { Moses Lake, } \\
\text { Rocky Ford arm }\end{array}$ & $07 / 14 / 92$ & 16 & 66 & 2.5 & 2.0 \\
\hline MLP & $\begin{array}{l}\text { Moses Lake, } \\
\text { Parker Hom arm }\end{array}$ & $07 / 14 / 92$ & 14 & 62 & 4.1 & 2.2 \\
\hline MLS & $\begin{array}{l}\text { Moses Lake, } \\
\text { south end }\end{array}$ & $07 / 14 / 92$ & 13 & 57 & 4.3 & 2.4 \\
\hline PRW & $\begin{array}{l}\text { Potholes Reservoir, } \\
\text { west arm }\end{array}$ & $07 / 15 / 92$ & 19 & 65 & 2.4 & 1.4 \\
\hline PRE & $\begin{array}{l}\text { Potholes Reservoir, } \\
\text { cast arm }\end{array}$ & $07 / 16 / 92$ & 20 & 67 & 1.6 & 1.2 \\
\hline Ww & $\begin{array}{l}\text { Winchester } \\
\text { Wasteway }\end{array}$ & $07 / 15 / 92$ & 12 & 52 & 6.6 & 3.9 \\
\hline FHW & $\begin{array}{l}\text { Prenchman Hills } \\
\text { Wasteway }\end{array}$ & $07 / 15 / 92$ & 20 & 79 & 2.0 & 1.5 \\
\hline LCW & Lind Coulee Wasteway & $07 / 1492$ & 21 & 96 & 1.4 & 1.1 \\
\hline SL & Soda Lake & $07 / 17 / 92$ & 17 & 74 & 0.93 & 0.83 \\
\hline$C \mathrm{CM}$ & $\begin{array}{l}\text { Lower Crab Creek, } \\
\text { McManamon Road }\end{array}$ & $07 / 15 / 92$ & 17 & 72 & 3.6 & 3.2 \\
\hline LGL & Lower Goose Lake & $07 / 17 / 92$ & 18 & 66 & 0.37 & 0.35 \\
\hline SHCb & $\begin{array}{l}\text { Sand Hollow Creek } \\
\text { at mouth }\end{array}$ & $07 / 16 / 92$ & 18 & 76 & 1.7 & 1.3 \\
\hline $\mathrm{CCB}$ & $\begin{array}{l}\text { Crab Creek near } \\
\text { Beverly }\end{array}$ & $07 / 16 / 92$ & 14 & 61 & 4.0 & 2.4 \\
\hline SMW & $\begin{array}{l}\text { Saddle Monntain } \\
\text { Wasteway }\end{array}$ & $07 / 17 / 92$ & 15 & 54 & 0.71 & 0.49 \\
\hline ELW & EL68D Wasteway & $07 / 15 / 92$ & 19 & 80 & 1.5 & 1.4 \\
\hline WBWb & $\begin{array}{l}\text { Wahluke Branch } \\
\text { Wasteway Lake }\end{array}$ & $07 / 17 / 92$ & 16 & 64 & 2.4 & 1.5 \\
\hline PEW & PE16.4 Wasteway & $07 / 16 / 92$ & 18 & 67 & 0.48 & 0.23 \\
\hline $\mathrm{ECW}$ & $\begin{array}{l}\text { Esquatzel Coulee } \\
\text { Wasteway }\end{array}$ & $07 / 16992$ & 18 & 71 & 0.82 & 0.63 \\
\hline \multicolumn{7}{|c|}{ Duplicate Samole } \\
\hline PRW & $\begin{array}{l}\text { Potholes Reservoir, } \\
\text { west arm }\end{array}$ & $07 / 15 / 92$ & 15 & $\mathbf{5 2}$ & 3.6 & 2.1 \\
\hline
\end{tabular}


Table 28.--Results of analyses for pesticides and other organic compounds in the less-than-2-millimeter size fraction of bottom-sediment samples from the Columbia Basin Project, July 1992

[ $\mu \mathrm{g} / \mathrm{kg}$, micrograms per kilogram; <, less than]

\begin{tabular}{|c|c|c|c|c|c|c|c|c|c|c|c|}
\hline $\begin{array}{l}\text { Map } \\
\text { identi- } \\
\text { fier } \\
\text { (fig. 9) }\end{array}$ & Station name & Date & $\begin{array}{l}\text { Aldrin, } \\
\text { total }\end{array}$ & $\begin{array}{l}\text { Chlor- } \\
\text { dane, } \\
\text { total }\end{array}$ & $\begin{array}{l}\text { DDD, } \\
\text { total }\end{array}$ & $\begin{array}{l}\text { DDE. } \\
\text { total }\end{array}$ & $\begin{array}{l}\text { DDT, } \\
\text { total }\end{array}$ & $\begin{array}{l}\text { Diel- } \\
\text { drin } \\
\text { total }\end{array}$ & $\begin{array}{l}\text { Eado- } \\
\text { sulfan, } \\
\text { total }\end{array}$ & $\begin{array}{l}\text { Endrin, } \\
\text { total }\end{array}$ & $\begin{array}{l}\text { Ethylan } \\
\text { (Perth ^ne) }\end{array}$ \\
\hline BCL & Billy Clapp Lake & $07 / 13 / 92$ & $<0.1$ & $<1$ & $<0.1$ & $<0.1$ & $<0.1$ & $<0.1$ & $<0.1$ & $<0.1$ & $<1$ \\
\hline RFC & Rocky Ford Creek & $07 / 13 / 92$ & $<0.5$ & $<$ & 1.6 & 4.4 & 0.2 & $<0.2$ & $<0.5$ & $<0.2$ & $<$ \\
\hline $\mathrm{CCU}$ & Upper Crab Creek & $07 / 14 / 92$ & 0.4 & $<1$ & $<0.1$ & 6.0 & $<0.1$ & 3.6 & $<0.2$ & $<0.1$ & $<1$ \\
\hline MLR & $\begin{array}{l}\text { Moses Lake, } \\
\text { Rocky Ford arm }\end{array}$ & $07 / 14 / 92$ & $<0.1$ & $<1$ & 1.6 & 1.2 & $<0.1$ & $<0.1$ & $<0.1$ & $<0.1$ & $<1$ \\
\hline MLP & $\begin{array}{l}\text { Moses Lake, } \\
\text { Parker Hom arm }\end{array}$ & $07 / 14 / 92$ & $<0.1$ & $<1$ & 1.1 & 0.9 & 0.4 & $<0.1$ & $<0.1$ & $<0.1$ & $<1$ \\
\hline MLS & $\begin{array}{l}\text { Moses Lake, } \\
\text { south end }\end{array}$ & $07 / 14 / 92$ & $<0.5$ & $<1$ & 1.3 & 2.0 & $<0.5$ & $<0.1$ & $<0.1$ & $<0.5$ & $<1$ \\
\hline PRW & $\begin{array}{l}\text { Potholes Reservoir, } \\
\text { west arm }\end{array}$ & $07 / 15 / 92$ & $<0.1$ & $<1$ & $<0.1$ & 0.3 & 0.1 & $<0.1$ & $<0.1$ & $<0.1$ & $<1$ \\
\hline PRE & $\begin{array}{l}\text { Potholes Reservoir, } \\
\text { east arm }\end{array}$ & $07 / 16 / 92$ & $<0.1$ & $<1$ & $<0.1$ & $<0.1$ & $<0.1$ & $<0.1$ & $<0.1$ & $<0.1$ & $<1$ \\
\hline ww & Winchester Wasteway & $07 / 15 / 92$ & $<0.2$ & $<1$ & $<.2$ & $<0.2$ & $<0.2$ & 0.2 & $<0.2$ & $<0.2$ & $<$ \\
\hline FHW & $\begin{array}{l}\text { Frenchman Hills } \\
\text { Wasteway }\end{array}$ & $07 / 15 / 92$ & 0.7 & $<1$ & 0.7 & 2.0 & $<0.1$ & 0.7 & $<0.1$ & 0.1 & $<1$ \\
\hline LCW & Lind Coulee Wasteway & $07 / 14 / 92$ & -- & $<2$ & 1.2 & 0.8 & 4.0 & $<0.2$ & $<0.2$ & $<0.2$ & -- \\
\hline SL & Soda Lake & $07 / 17 / 92$ & $<0.1$ & $<1$ & 0.1 & 0.7 & 0.3 & $<0.1$ & $<0.1$ & $<0.1$ & $<1$ \\
\hline CCM & $\begin{array}{l}\text { Lower Crab Creek, } \\
\text { McManamon Road }\end{array}$ & $07 / 15 / 92$ & $<0.1$ & $<1$ & $<0.1$ & 0.3 & $<0.1$ & $<0.1$ & 0.1 & $<0.1$ & $<1$ \\
\hline LGL & Lower Goose Lake & $07 / 17 / 92$ & 0.1 & $<1$ & 0.7 & 3.7 & 0.4 & 1.4 & 0.3 & $<0.1$ & $<1$ \\
\hline $\mathrm{SHCb}$ & $\begin{array}{l}\text { Sand Hollow Creek } \\
\text { at mouth }\end{array}$ & $07 / 15 / 92$ & $<0.1$ & $<1$ & 0.2 & 1.0 & 0.2 & 0.7 & 0.1 & $<0.1$ & $<1$ \\
\hline CCB & $\begin{array}{l}\text { Crab Creek near } \\
\text { Beverly }\end{array}$ & $07 / 16 / 92$ & $<0.1$ & $<1$ & 0.2 & 0.2 & $<0.1$ & $<0.1$ & $<0.1$ & $<0.1$ & $<1$ \\
\hline SMW & $\begin{array}{l}\text { Saddle Mountain } \\
\text { Wasteway }\end{array}$ & 07/17/92 & 0.1 & $<1$ & 0.1 & 0.1 & $<0.1$ & $<0.1$ & 0.2 & $<0.1$ & $<1$ \\
\hline ELW & EL68D Wasteway & $07 / 15 / 92$ & 0.3 & $<1$ & 2.7 & 7.8 & 0.3 & 1.3 & $<0.1$ & $<0.1$ & $<1$ \\
\hline WBWb & $\begin{array}{l}\text { Wahluke Branch } \\
\text { Wasteway Lake }\end{array}$ & $07 / 17 / 92$ & $<0.1$ & $<1$ & $<0.1$ & 0.1 & $<0.1$ & $<0.1$ & $<0.1$ & $<0.1$ & $<1$ \\
\hline PEW & PE16.4 Wasteway & $07 / 16 / 92$ & $<0.1$ & $<1$ & $<0.1$ & 0.1 & $<0.1$ & 0.1 & $<0.1$ & $<0.1$ & $<1$ \\
\hline ECW & $\begin{array}{l}\text { Esquatzel Coulee } \\
\text { Wasteway }\end{array}$ & $07 / 16 / 92$ & $<0.1$ & $<1$ & $<0.1$ & 0.5 & $<0.1$ & 0.2 & $<0.1$ & $<0.1$ & $<1$ \\
\hline
\end{tabular}

\section{Duplicate Sample}

$\begin{array}{llllllllllll}\text { PRW Potholes Reservoir, } & 07 / 15 / 92 & <0.4 & <1 & <0.4 & 0.2 & <0.4 & <0.1 & <0.4 & <.1 & <1\end{array}$ west arm 
Table 28. --Results of analyses for pesticides and other organic compounds in the less-than-2-millimeter size fraction of bottom-sediment samples from the Columbia Basin Project, July 1992--Continued

\begin{tabular}{|c|c|c|c|c|c|c|c|c|c|c|}
\hline $\begin{array}{l}\text { Map } \\
\text { identi- } \\
\text { fier } \\
\text { (fig. 9) }\end{array}$ & Station name & Date & $\begin{array}{l}\text { Hepta- } \\
\text { chlor, } \\
\text { total }\end{array}$ & $\begin{array}{l}\text { Hepta- } \\
\text { chlor } \\
\text { epoxide } \\
\text { total }\end{array}$ & $\begin{array}{l}\text { Lin- } \\
\text { dane, } \\
\text { total }\end{array}$ & $\begin{array}{l}\text { Meth- } \\
\text { oxy- } \\
\text { chlor, } \\
\text { total }\end{array}$ & $\begin{array}{l}\text { Mirex, } \\
\text { total }\end{array}$ & $\begin{array}{l}\text { Toxa- } \\
\text { phene, } \\
\text { total }\end{array}$ & $\begin{array}{l}\text { PCB, } \\
\text { total }\end{array}$ & $\begin{array}{l}\text { PCN, } \\
\text { total }\end{array}$ \\
\hline $\mathrm{BCL}$ & Billy Clapp Lake & $07 / 13 / 92$ & $<0.1$ & $<0.1$ & $<0.1$ & $<0.1$ & $<0.2$ & $<10$ & $<1$ & $<1$ \\
\hline RFC & Rocky Ford Creek & $07 / 13 / 92$ & $<0.2$ & $<0.2$ & $<0.2$ & 1.4 & $<0.2$ & $<20$ & 2 & $<$ \\
\hline $\mathrm{CCU}$ & Upper Crab Creek & $07 / 14 / 92$ & $<0.1$ & $<0.1$ & $<0.1$ & $<1$ & $<0.1$ & $<10$ & $<1$ & $<1$ \\
\hline MLR & $\begin{array}{l}\text { Moses Lake, } \\
\text { Rocky Ford arm }\end{array}$ & $07 / 14 / 92$ & $<0.2$ & $<0.1$ & $<0.1$ & $<\mathrm{l}$ & $<0.1$ & $<10$ & $<1$ & $<1$ \\
\hline MLP & $\begin{array}{l}\text { Moses Lake, } \\
\text { Parker Horn arm }\end{array}$ & $07 / 14 / 92$ & $<0.1$ & 0.8 & $<0.1$ & 0.4 & $<0.1$ & $<10$ & $<1$ & $<1$ \\
\hline MLS & $\begin{array}{l}\text { Moses Lake, } \\
\text { south end }\end{array}$ & $07 / 14 / 92$ & $<0.1$ & $<0.1$ & $<0.1$ & $<1$ & $<0.4$ & $<10$ & $<1$ & $<1$ \\
\hline PRW & $\begin{array}{l}\text { Potholes Reservoir, } \\
\text { west arm }\end{array}$ & $07 / 15 / 92$ & $<0.1$ & $<0.1$ & $<0.2$ & $<1$ & 0.2 & $<10$ & $<1$ & $<1$ \\
\hline PRE & $\begin{array}{l}\text { Potholes Reservoir, } \\
\text { east arm }\end{array}$ & $07 / 16 / 92$ & $<0.1$ & $<0.1$ & $<0.1$ & $<0.1$ & $<0.1$ & $<10$ & $<1$ & $<1$ \\
\hline WW & Winchester Wasteway & $07 / 15 / 92$ & $<0.2$ & 1.0 & $<0.2$ & 0.4 & $<0.2$ & $<20$ & $\alpha$ & $\alpha$ \\
\hline FHW & $\begin{array}{l}\text { Frenchman Hills } \\
\text { Wasteway }\end{array}$ & $07 / 15 / 92$ & $<0.1$ & $<0.1$ & $<0.1$ & $<.1$ & $<0.1$ & $<10$ & $<1$ & $<1$ \\
\hline LCW & Lind Coulce Wasteway & $07 / 14 / 92$ & $<0.2$ & 1.0 & - & 2.4 & $<0.2$ & $<20$ & $<2$ & $<2$ \\
\hline SL & Soda Lake & $07 / 17 / 92$ & $<0.1$ & $<0.1$ & $<0.1$ & $<0.1$ & $<0.1$ & $<10$ & $<1$ & $<1$ \\
\hline $\mathbf{C C M}$ & $\begin{array}{l}\text { Lower Crab Creek, } \\
\text { McManamon Road }\end{array}$ & $07 / 15 / 92$ & $<0.1$ & 0.4 & $<0.1$ & 0.5 & $<0.1$ & $<10$ & $<1$ & $<1$ \\
\hline LGL & Lower Goose Lake & $07 / 17 / 92$ & $<0.1$ & $<0.1$ & $<0.1$ & 0.2 & $<0.1$ & $<10$ & $<1$ & $<1$ \\
\hline $\mathrm{SHCb}$ & $\begin{array}{l}\text { Sand Hollow Creek } \\
\text { at mouth }\end{array}$ & $07 / 16 / 92$ & $<0.1$ & $<0.1$ & $<0.1$ & 0.1 & $<0.1$ & $<10$ & $<1$ & $<1$ \\
\hline $\mathrm{CCB}$ & $\begin{array}{l}\text { Crab Creek near } \\
\text { Beverly }\end{array}$ & $07 / 16 / 92$ & $<0.1$ & $<0.1$ & $<0.1$ & 0.6 & $<0.1$ & $<10$ & $<1$ & $<1$ \\
\hline SMW & $\begin{array}{l}\text { Saddle Mountain } \\
\text { Wasteway }\end{array}$ & $07 / 17 / 92$ & $<0.1$ & $<0.1$ & $<0.1$ & $<0.1$ & $<0.1$ & $<10$ & $<1$ & $<1$ \\
\hline ELW & EL68D Wasteway & $07 / 15 / 92$ & $<0.1$ & $<0.1$ & $<0.1$ & $<0.1$ & $<0.1$ & $<10$ & $<1$ & $<1$ \\
\hline WBWb & $\begin{array}{l}\text { Wahluke Branch } \\
\text { Wasteway Lake }\end{array}$ & $07 / 17 / 92$ & $<0.1$ & $<0.1$ & $<0.1$ & $<0.1$ & $<0.5$ & $<10$ & $<1$ & $<1$ \\
\hline PEW & PE16.4 Wasteway & $07 / 16 / 92$ & $<0.1$ & $<0.1$ & $<0.1$ & $<0.1$ & $<0.1$ & $<10$ & $<1$ & $<1$ \\
\hline $\mathrm{ECW}$ & $\begin{array}{l}\text { Esquatzel Coulce } \\
\text { Wasteway }\end{array}$ & $07 / 16 / 92$ & $<0.1$ & $<0.1$ & $<0.1$ & 0.1 & $<0.1$ & $<10$ & $<1$ & $<1$ \\
\hline
\end{tabular}

Duplicate.Sample

$\begin{array}{lllllllllll}\text { PRW Potholes Reservoir, } & 07 / 15 / 92 & <0.4 & <0.4 & <0.4 & <1 & <0.1 & <10 & <1\end{array}$ west arm 
Table 29.--Measurements of mallard, western grebe, and American coot eggs collected from the Co'umbia Basin Project in 1992

\begin{tabular}{|c|c|c|c|c|c|c|c|c|c|c|}
\hline $\begin{array}{l}\text { Species, } \\
\text { site, map } \\
\text { identifier, } \\
\text { and sample } \\
\text { number } \\
\text { (fig. 9) }\end{array}$ & $\begin{array}{l}\text { Date } \\
\text { coll- } \\
\text { ected }\end{array}$ & $\begin{array}{l}\text { Date } \\
\text { harv- } \\
\text { ested }\end{array}$ & Age' & $\begin{array}{l}\text { Whole } \\
\text { egg } \\
\text { weight } \\
\text { (grams) }\end{array}$ & $\begin{array}{l}\text { Egg } \\
\text { length } \\
\text { (milli- } \\
\text { meters) }\end{array}$ & $\begin{array}{c}\text { Egg } \\
\text { width } \\
\text { (milli- } \\
\text { meters) }\end{array}$ & $\begin{array}{c}\text { Egg } \\
\text { volume } \\
\text { (milli- } \\
\text { liters) }\end{array}$ & $\begin{array}{c}\text { Egg } \\
\text { weight } \\
\text { (grams) }\end{array}$ & $\begin{array}{c}\text { Sh:ll } \\
\text { weight } \\
\text { (graๆs) }\end{array}$ & $\begin{array}{l}\text { Shell } \\
\text { thick- } \\
\text { ness } \\
\text { (milli- } \\
\text { meters) }\end{array}$ \\
\hline
\end{tabular}

Mallard eggs, Moses Lake (MLS)

$\begin{array}{lllrlllllll}\text { MLSMEM01 } & 5 / 2 & 5 / 4 & 5 & 50.0 & 57.56 & 42.52 & 54.1 & 45.1 & 5.6 & 0.403 \\ \text { MLSMEC01 } & 5 / 2 & 5 / 4 & 23 & 44.7 & 56.24 & 40.50 & 47.1 & 40.8 & 4.2 & 0.363 \\ \text { MLSMEC02 } & 5 / 2 & 5 / 4 & 19 & 50.6 & 57.38 & 42.16 & 41.7 & 45.5 & 4.7 & 0.362 \\ \text { MLSMEM02 } & 5 / 2 & 5 / 4 & 15 & 50.0 & 54.40 & 42.56 & 50.2 & 45.1 & 4.4 & 0.337 \\ \text { MLSMEC03 } & 5 / 2 & 5 / 4 & 21 & 46.9 & 57.28 & 41.34 & 50.1 & 42.3 & 4.1 & 0.341 \\ \text { MLSMEM03 } & 5 / 2 & 5 / 4 & 19 & 46.5 & 57.56 & 41.76 & 51.5 & 42.1 & 3.9 & 0.332 \\ \text { MLSMEC04 } & 5 / 2 & 5 / 4 & 20 & 46.2 & 54.10 & 41.18 & 47.3 & 41.4 & 4.3 & 0.388 \\ \text { MLSMEM04 } & 5 / 2 & 5 / 4 & 22 & 41.6 & 54.48 & 40.42 & 45.2 & 37.0 & 4.2 & 0.362 \\ \text { MLSMEC05 } & 5 / 2 & 5 / 4 & 8 & 44.5 & 55.90 & 40.36 & 46.4 & 40.3 & 3.6 & 0.346 \\ \text { MLSMEM05 } & 5 / 2 & 5 / 4 & 14 & 47.3 & 58.20 & 40.02 & 47.3 & 42.6 & 4.3 & 0.355\end{array}$

Western grebe eggs, Potholes Reservoir, east arm (PRE)

$\begin{array}{lllllllllll}\text { PREGEM01 } & 5 / 14 & 5 / 14 & 1 & 47.7 & 57.60 & 39.26 & 45.3 & 42.3 & 4.5 & 0.426 \\ \text { PREGEC01 } & 5 / 14 & 5 / 14 & 4 & 42.9 & 58.94 & 38.78 & 44.0 & 38.4 & 4.0 & 0.381 \\ \text { PREGEC02 } & 5 / 14 & 5 / 14 & 2 & 45.8 & 58.64 & 38.54 & 43.8 & 40.5 & 4.3 & 0.399 \\ \text { PREGEM02 } & 5 / 14 & 5 / 14 & 3 & 51.6 & 61.58 & 39.92 & 50.8 & 45.9 & 5.1 & 0.432 \\ \text { PREGEC03 } & 5 / 14 & 5 / 14 & 4 & 45.2 & 56.92 & 39.74 & 44.9 & 40.0 & 4.5 & 0.433 \\ \text { PREGEM03 } & 5 / 14 & 5 / 14 & 3 & 41.0 & 53.16 & 38.82 & 39.5 & 35.6 & 4.4 & 0.472 \\ \text { PREGEC04 } & 5 / 14 & 5 / 14 & 1 & 44.7 & 59.42 & 38.68 & 45.6 & 39.1 & 4.5 & 0.380 \\ \text { PREGEM04 } & 5 / 14 & 5 / 14 & 1 & 47.2 & 57.44 & 38.62 & 43.7 & 40.6 & 5.1 & 0.481\end{array}$

Western grebe eggs, Potholes Reservoir, west arm (PRW)

$\begin{array}{lllllllllll}\text { PRWGEC01 } & 5 / 11 & 5 / 12 & 1 & 53.6 & 62.34 & 39.82 & 50.0 & 46.5 & 5.3 & 0.477 \\ \text { PRWGEM01 } & 5 / 11 & 5 / 12 & 1 & 46.4 & 60.14 & 37.78 & 43.0 & 39.6 & 4.7 & 0.428 \\ \text { PRWGEC02 } & 5 / 11 & 5 / 12 & 1 & 48.1 & 57.66 & 39.02 & 44.4 & 39.7 & 5.6 & 0.528 \\ \text { PRWGEM02 } & 5 / 11 & 5 / 12 & 1 & 50.7 & 57.42 & 40.18 & 47.0 & 43.8 & 5.0 & 0.457 \\ \text { PRWGEC03 } & 5 / 11 & 5 / 12 & 2 & 52.2 & 60.50 & 40.18 & 50.3 & 46.8 & 4.9 & 0.426 \\ \text { PRWGEM03 } & 5 / 11 & 5 / 12 & 4 & 46.7 & 58.50 & 39.64 & 45.9 & 40.8 & 5.3 & 0.466 \\ \text { PRWGEC04 } & 5 / 11 & 5 / 12 & 1 & 43.1 & 58.04 & 36.88 & 40.0 & 38.1 & 4.0 & 0.452 \\ \text { PRWGEM04 } & 5 / 11 & 5 / 12 & 1 & 48.9 & 58.74 & 39.52 & 45.9 & 42.7 & 4.6 & 0.454\end{array}$

American coot eggs, Billy Clapp Lake (BCL)

$\begin{array}{lllllllllll}\text { BCLCEC01 } & 5 / 7 & 5 / 11 & 2 & 30.0 & 50.10 & 34.24 & 28.9 & 26.6 & 2.9 & 0.342 \\ \text { BCLCEM01 } & 5 / 7 & 5 / 11 & 3 & 28.7 & 48.44 & 33.74 & 27.8 & 25.5 & 2.7 & 0.316 \\ \text { BCLCEC02 } & 5 / 7 & 5 / 11 & 1 & 30.1 & 50.54 & 33.64 & 28.4 & 26.5 & 2.7 & 0.296 \\ \text { BCLCEM02 } & 5 / 7 & 5 / 11 & 1 & 26.3 & 46.88 & 32.32 & 24.4 & 22.7 & 2.6 & 0.364 \\ \text { BCLCEC03 } & 5 / 7 & 5 / 11 & 1 & 30.8 & 49.02 & 34.32 & 29.2 & 27.2 & 3.0 & 0.342 \\ \text { BCLCEM03 } & 5 / 7 & 5 / 11 & 2 & 30.5 & 50.38 & 33.90 & 29.1 & 27.2 & 3.0 & 0.345 \\ \text { BCLCEC04 } & 5 / 7 & 5 / 11 & 1 & 31.1 & 49.18 & 34.32 & 29.1 & 26.4 & 3.0 & 0.350 \\ \text { BCLCEM04 } & 5 / 7 & 5 / 11 & 1 & 32.1 & 49.74 & 35.12 & 30.0 & 28.0 & 3.0 & 0.357\end{array}$


Table 29.--Measurements of mallard, western grebe, and American coot eggs collected from the Columbia Basin Project in 1992--Continued

Species, site, map identifier, and sample number (fig. 9)
Date Date coll- harvected ested

\section{weight (milli-}

Egg
length
(milli-
meters)

Egg width (milli- volume meters) liters)
Shell

thick-

ness weight wei ̧̧ht (milli(grams) (grans) meters)

American coot eggs, Moses Lake (MLS)

$\begin{array}{lllllllllll}\text { MLSCEM01 } & 5 / 20 & 5 / 21 & 1 & 29.3 & 46.36 & 34.22 & 27.4 & 25.5 & 2.9 & 0.375 \\ \text { MLSCEC01 } & 5 / 20 & 5 / 21 & 1 & 28.4 & 46.98 & 34.20 & 26.8 & 24.9 & 2.7 & 0.358 \\ \text { MLSCEM02 } & 5 / 20 & 5 / 21 & 2 & 33.1 & 51.44 & 35.28 & 31.8 & 29.5 & 3.1 & 0.394 \\ \text { MLSCEC02 } & 5 / 20 & 5 / 21 & 1 & 31.5 & 48.32 & 35.08 & 27.8 & 27.5 & 2.8 & 0.359 \\ \text { MLSCEM03 } & 5 / 20 & 5 / 21 & 1 & 29.0 & 46.56 & 33.88 & 27.0 & 24.5 & 2.8 & 0.350 \\ \text { MLSCEC03 } & 5 / 20 & 5 / 21 & 1 & 31.0 & 51.58 & 33.68 & 29.0 & 26.9 & 2.9 & 0.355 \\ \text { MLSCEM04 } & 5 / 29 & 5 / 29 & 3 & 30.0 & 50.92 & 33.82 & 29.0 & 26.6 & 2.9 & 0.361 \\ \text { MLSCEC04 } & 5 / 29 & 5 / 29 & 1 & 27.1 & 46.48 & 32.90 & 25.4 & 23.6 & 2.6 & 0.382\end{array}$

American coot eggs, Winchester Wasteway (WW)

$\begin{array}{lllllllllll}\text { WCWCEC01 } & 5 / 26 & 5 / 28 & 1 & 28.3 & 47.94 & 34.42 & 26.4 & 24.7 & 2.7 & 0.338 \\ \text { WCWCEC02 } & 5 / 26 & 5 / 28 & 1 & 26.6 & 41.14 & 32.46 & 24.9 & 23.4 & 2.5 & 0.333 \\ \text { WCWCEC03 } & 5 / 26 & 5 / 28 & 1 & 35.2 & 53.14 & 35.06 & 32.6 & 30.4 & 3.4 & 0.370 \\ \text { WCWCEC04 } & 5 / 26 & 5 / 28 & 1 & 26.8 & 45.10 & 37.86 & 24.5 & 22.7 & 2.4 & 0.313 \\ \text { WCWCEM02 } & 5 / 26 & 5 / 28 & 1 & 27.4 & 48.14 & 32.60 & 25.3 & 23.8 & 2.6 & 0.326 \\ \text { WCWCEM03 } & 5 / 26 & 5 / 28 & 1 & 28.2 & 47.12 & 33.54 & 26.9 & 24.9 & 2.7 & 0.335 \\ \text { WCWCEM04 } & 5 / 26 & 5 / 28 & 1 & 35.1 & 53.44 & 35.30 & 32.4 & 30.8 & 3.2 & 0.357 \\ \text { WCWCEM01 } & 5 / 19 & 5 / 21 & 1 & 23.6 & 46.08 & 30.52 & 22.2 & 20.0 & 2.1 & 0.319\end{array}$

American coot eggs, Saddle Mountain Wasteway (SMW)

\begin{tabular}{lllllllllll} 
SMWCEM01 & $5 / 27$ & $5 / 29$ & 1 & 32.0 & 54.00 & 33.98 & 29.6 & 27.3 & 2.9 & 0.333 \\
SMWCEC01 & $5 / 27$ & $5 / 29$ & 1 & 32.0 & 53.74 & 33.82 & 29.4 & 28.0 & 3.0 & 0.362 \\
SMWCEM02 & $5 / 27$ & $5 / 29$ & 1 & 28.8 & 47.16 & 33.64 & 26.8 & 23.5 & 2.8 & 0.355 \\
SMWCEC02 & $5 / 27$ & $5 / 29$ & 1 & 28.4 & 47.40 & 33.28 & 26.6 & 22.9 & 2.9 & 0.352 \\
SMWCEC03 & $5 / 27$ & $5 / 29$ & 1 & 33.7 & 53.08 & 34.52 & 31.4 & 29.4 & 3.2 & 0.343 \\
SMWCEM04 & $5 / 27$ & $5 / 29$ & 1 & 28.9 & 48.50 & 33.74 & 27.2 & 25.0 & 2.7 & 0.335 \\
SMWCEM03 & $5 / 27$ & $5 / 29$ & 1 & 31.4 & 51.78 & 33.34 & 29.3 & 27.2 & 2.8 & 0.315 \\
SMWCEC04 & $5 / 27$ & $5 / 29$ & 1 & 28.7 & 48.66 & 33.34 & 26.5 & 24.8 & 2.7 & 0.322 \\
\hline
\end{tabular}

${ }^{1}$ For mallards, age is reported in days; for coots and grebes, age categories are (1) freshly laid, no limb buds; (2) limb buds but no feather tracts; ( 3 ) feather tracts but no feathers; (4) feathers. 


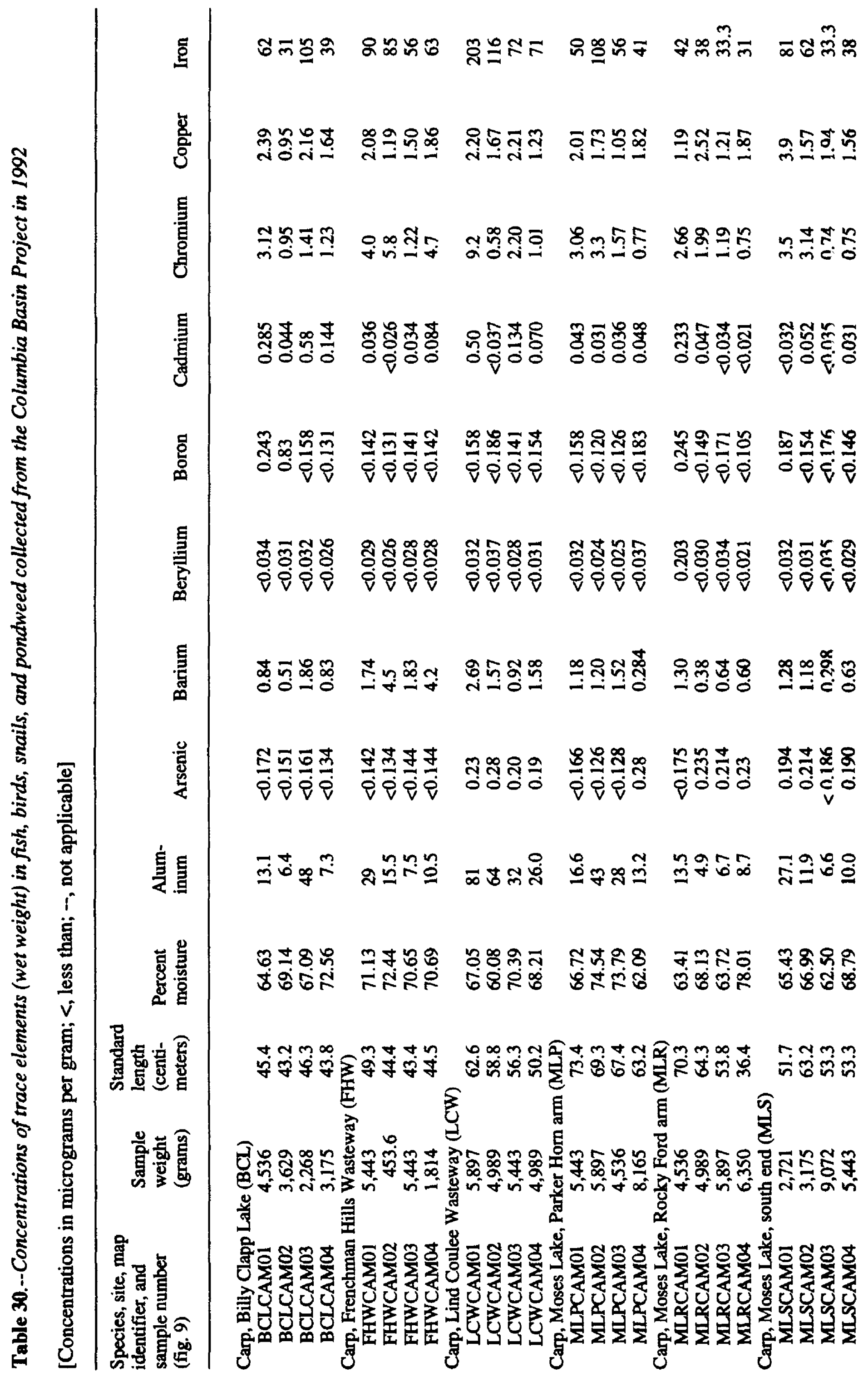




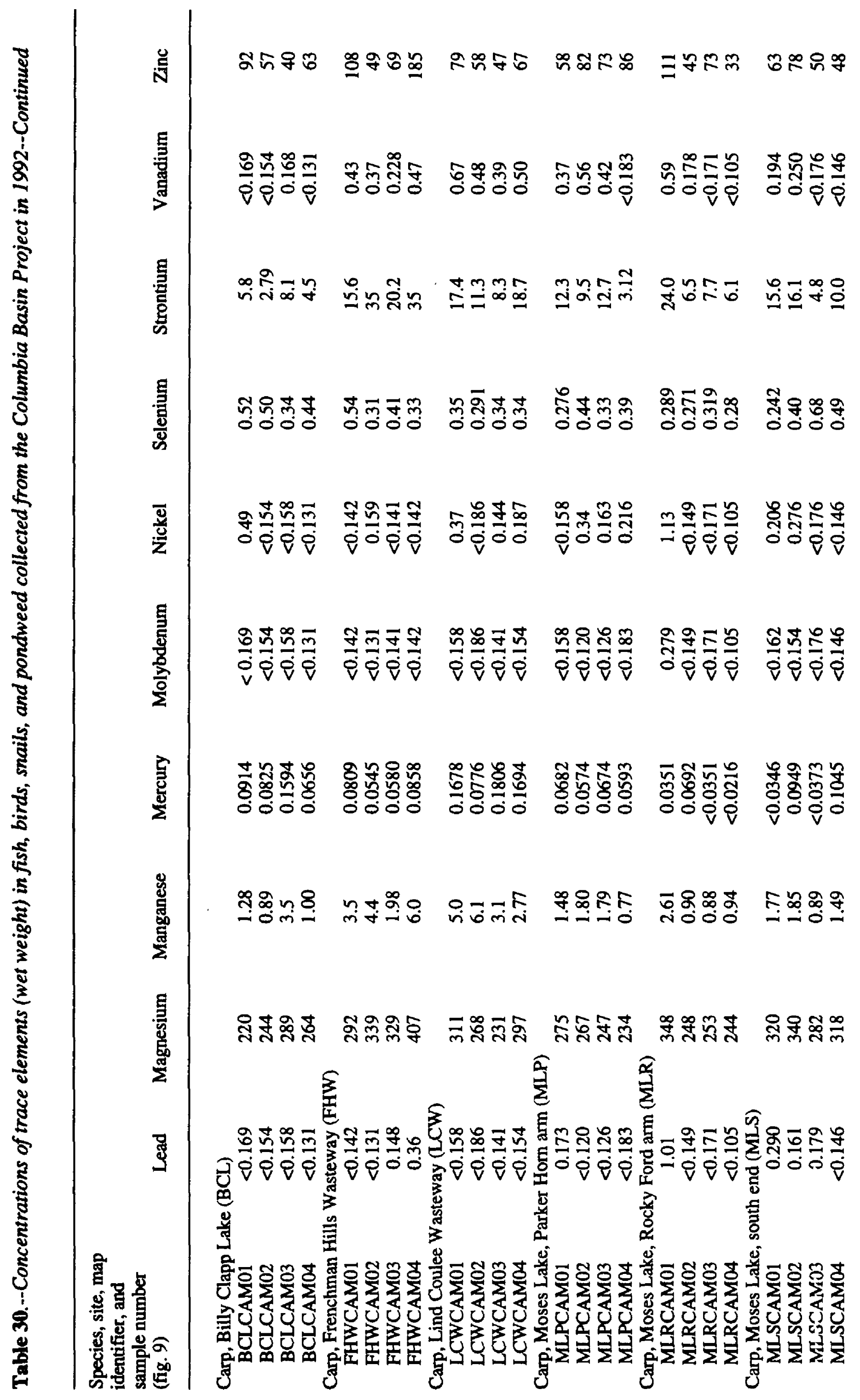




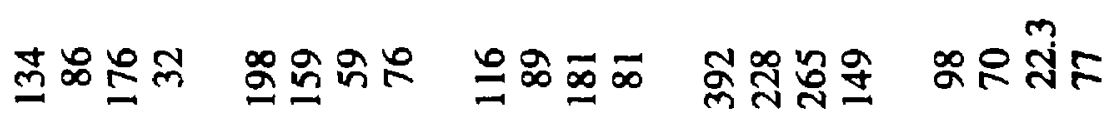

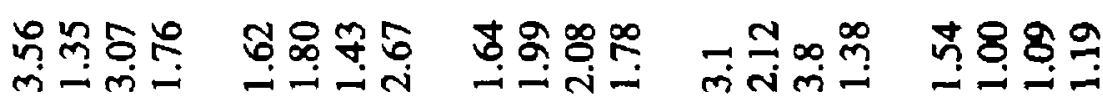

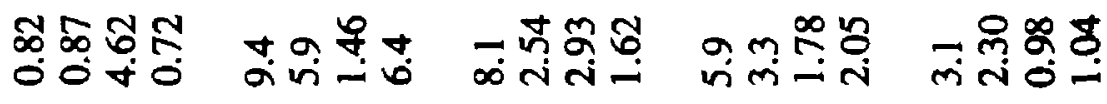

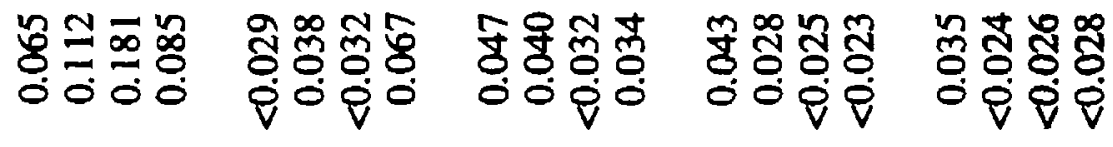

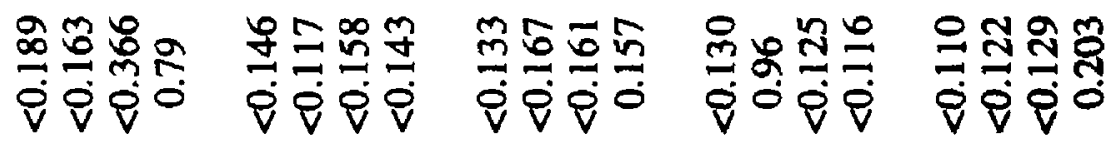

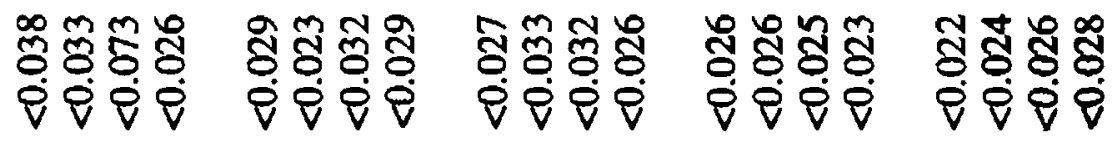

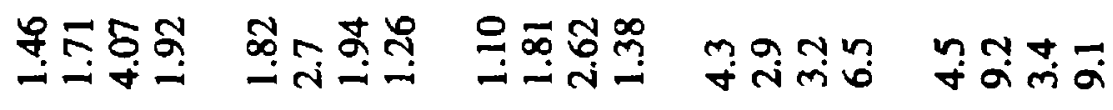

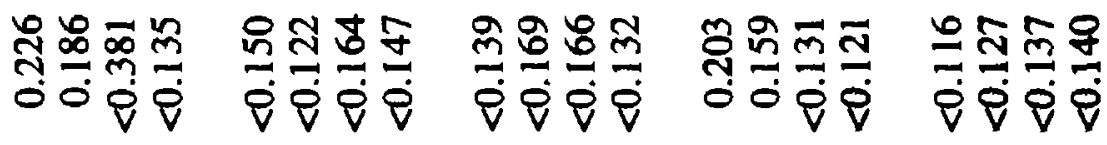

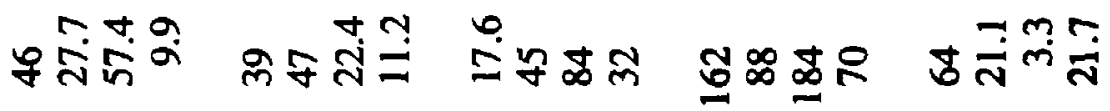

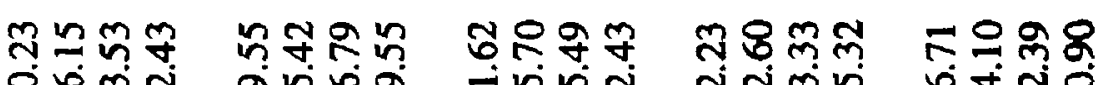

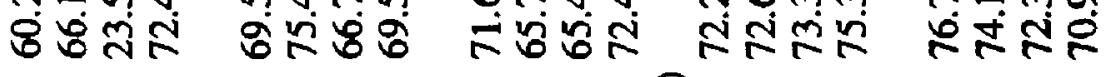

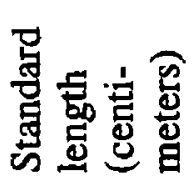

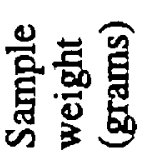

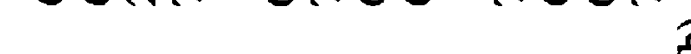
今े

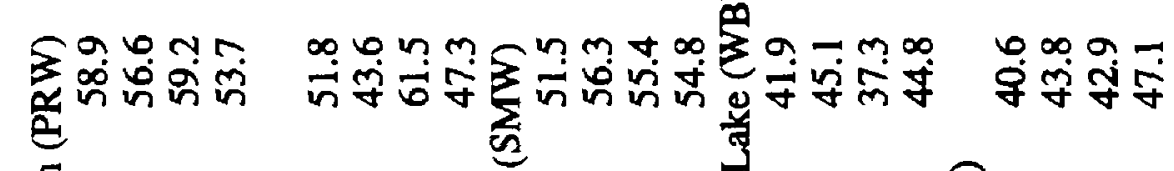

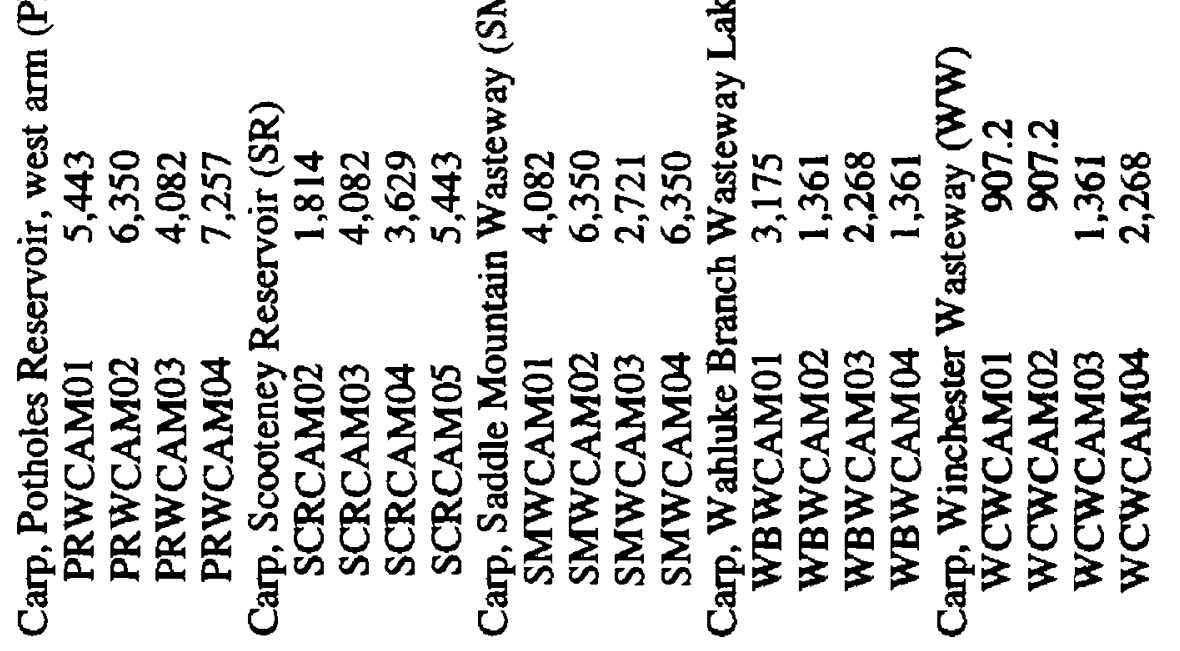




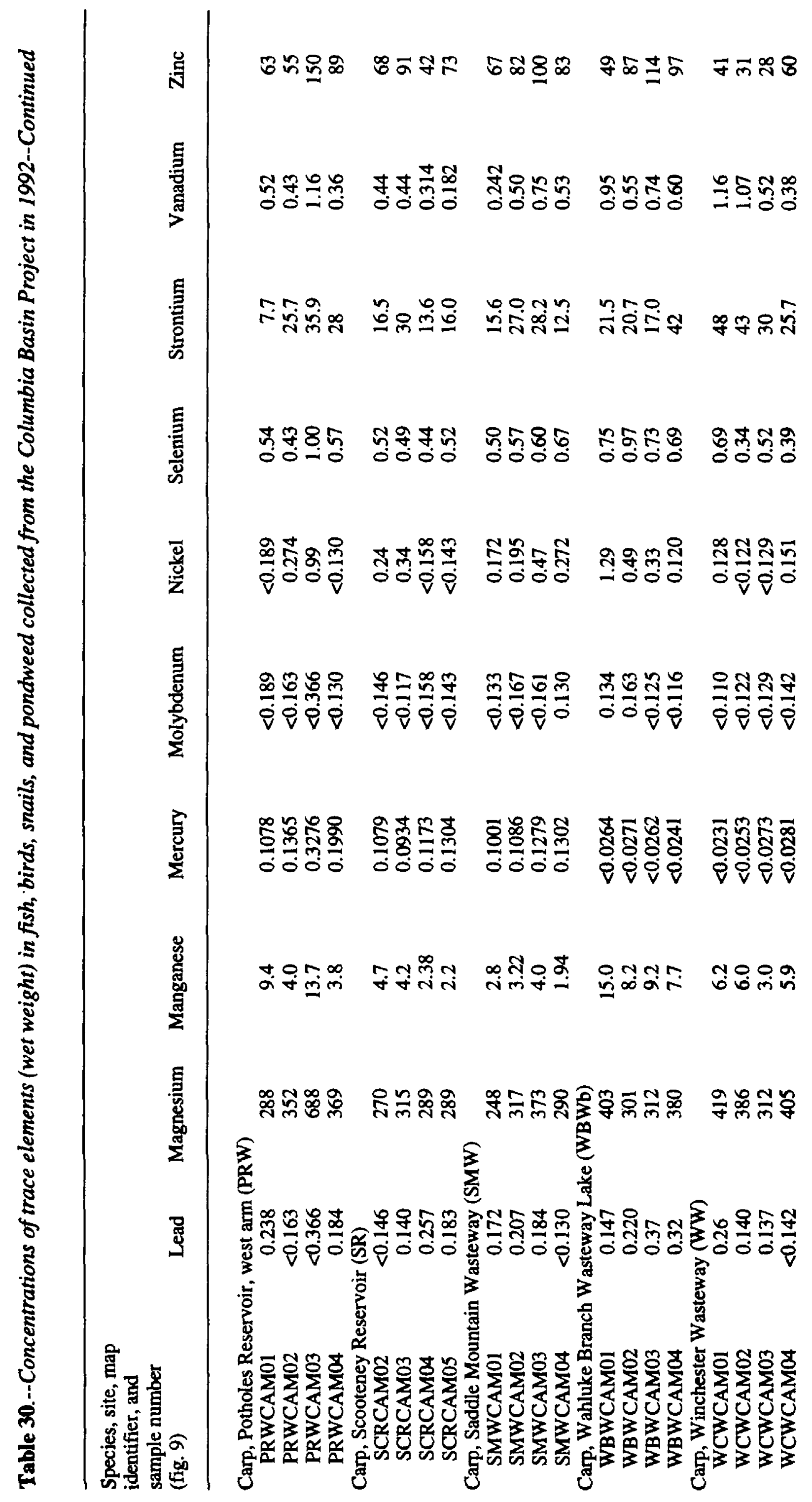




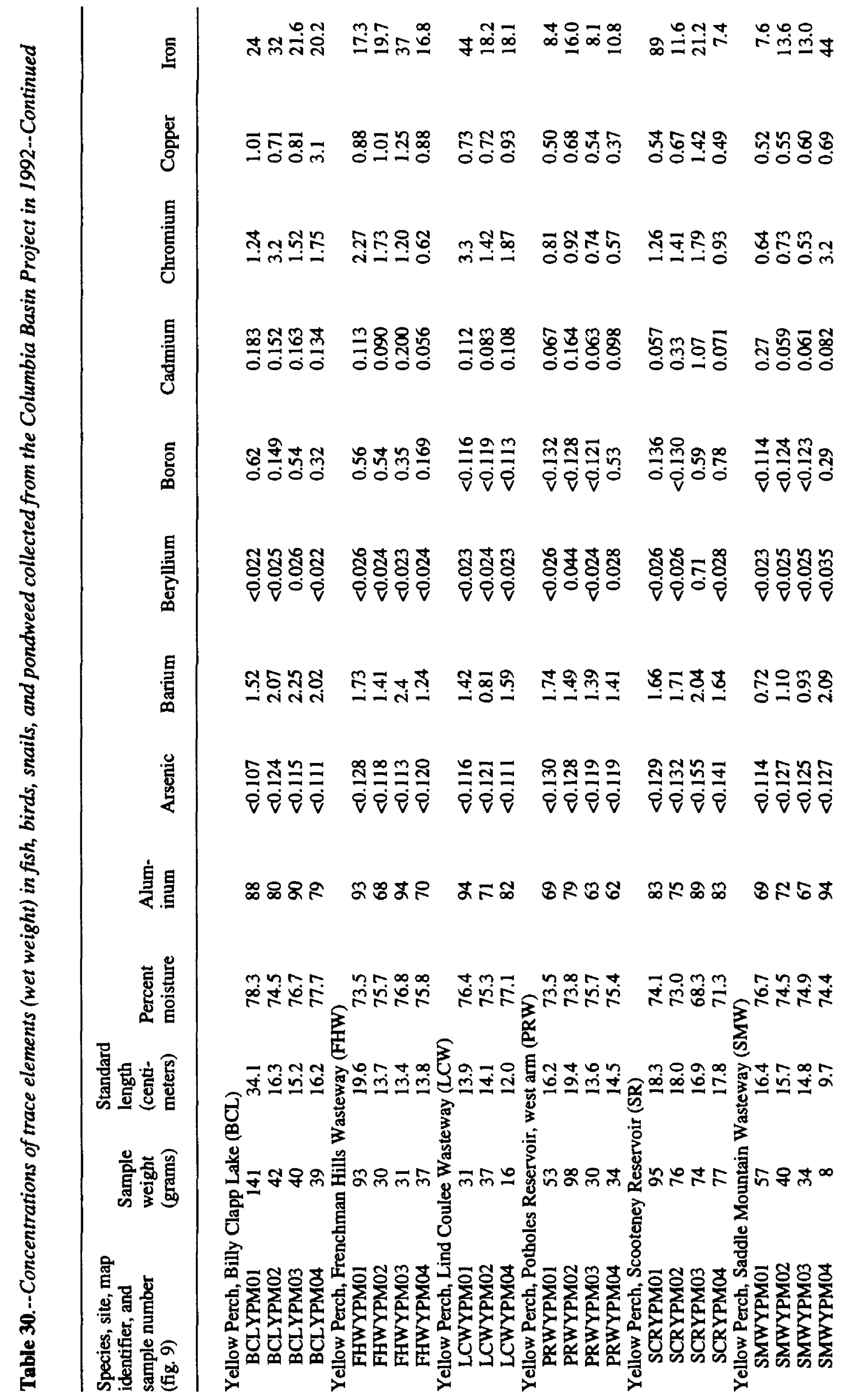




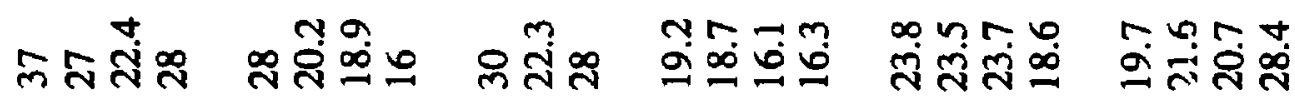

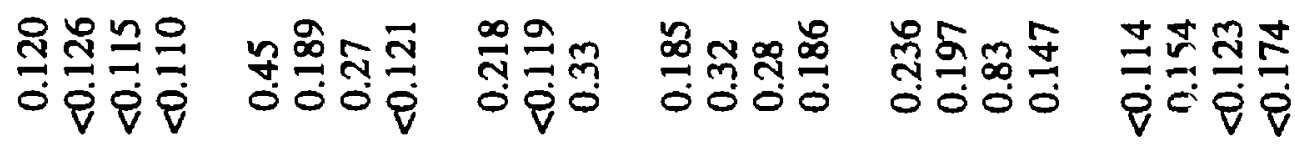

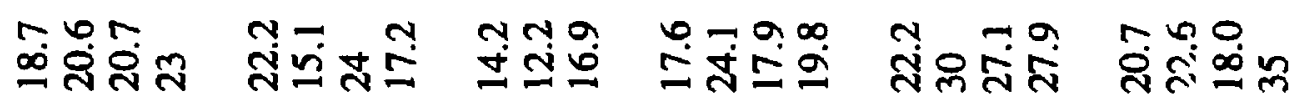

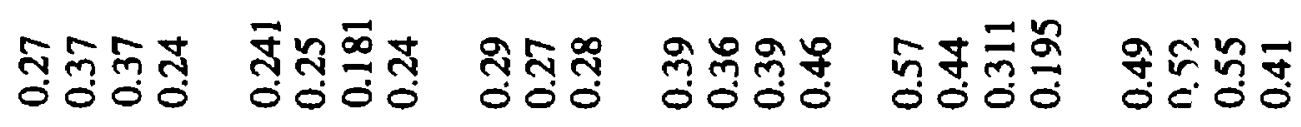

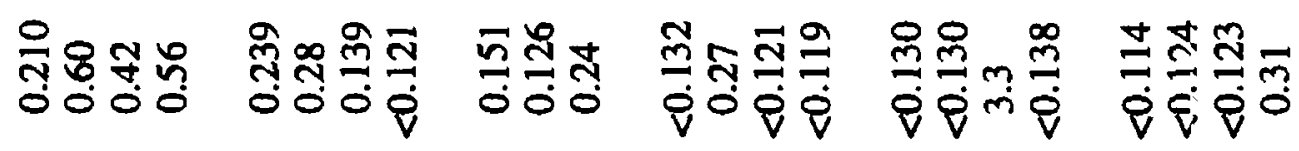

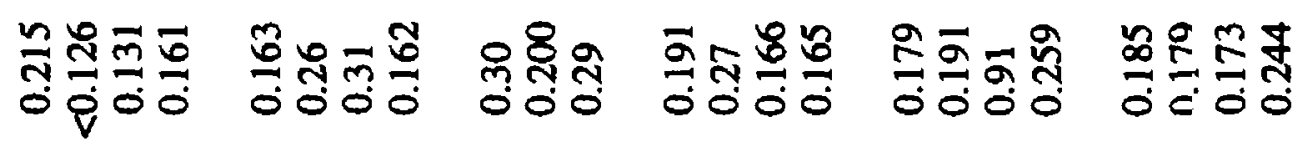

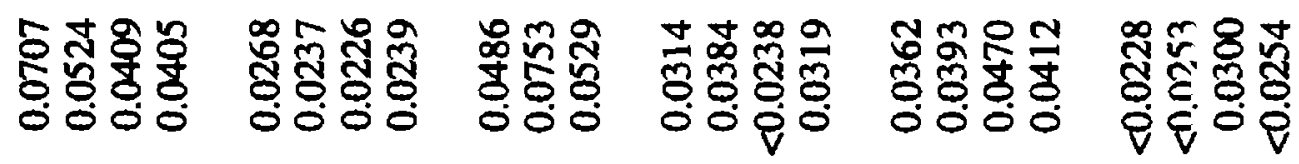

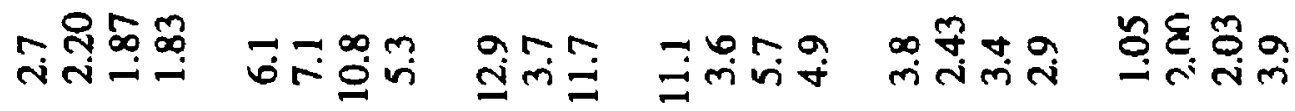

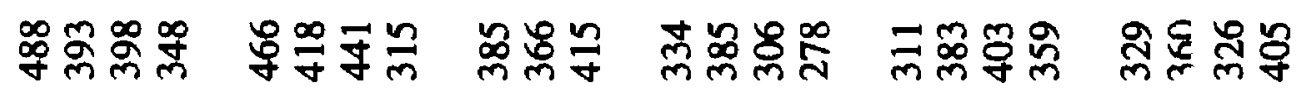

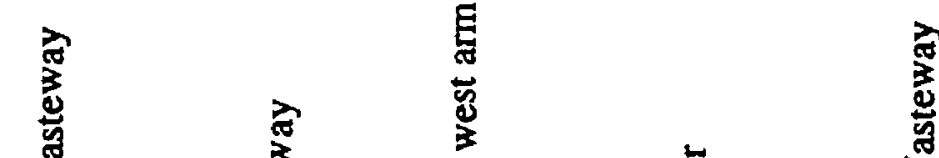

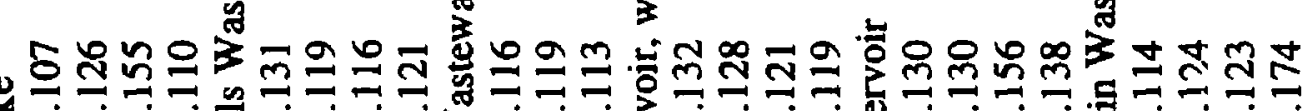

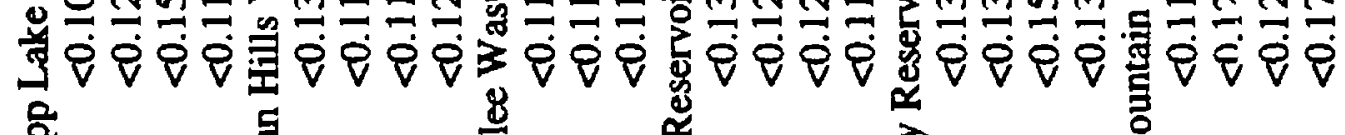

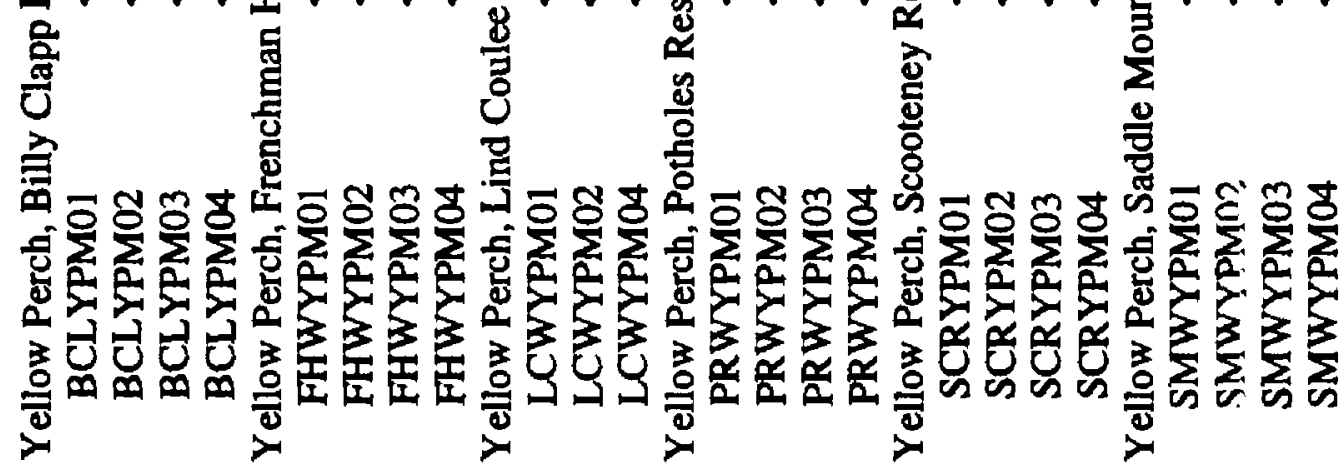




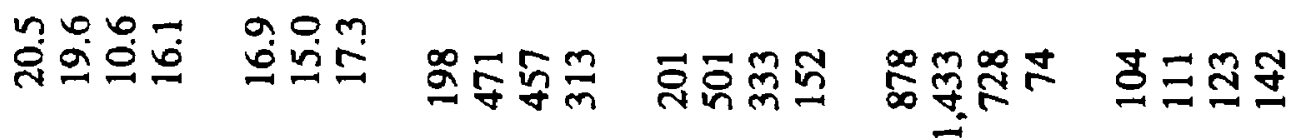

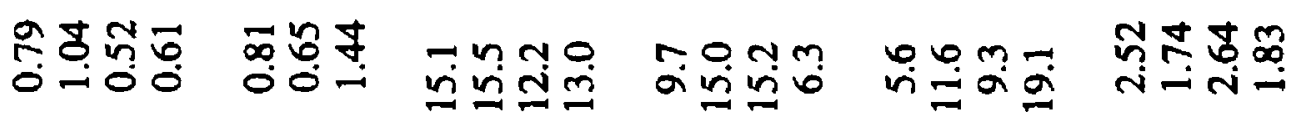

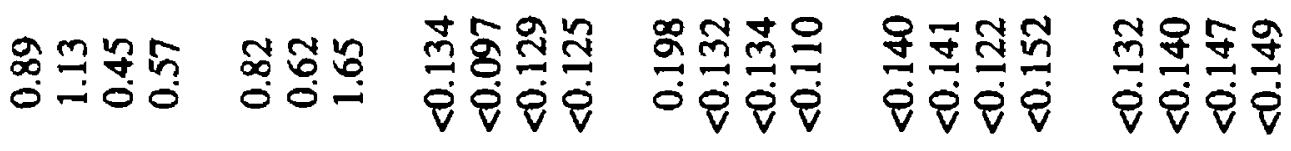

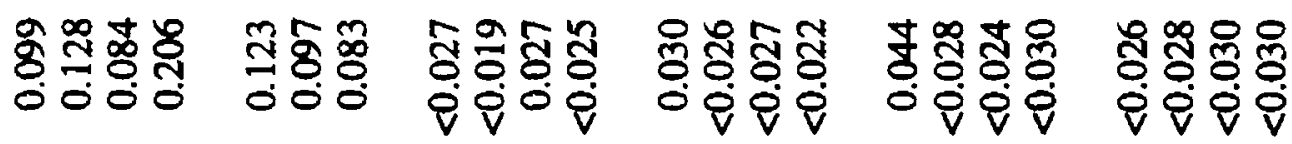

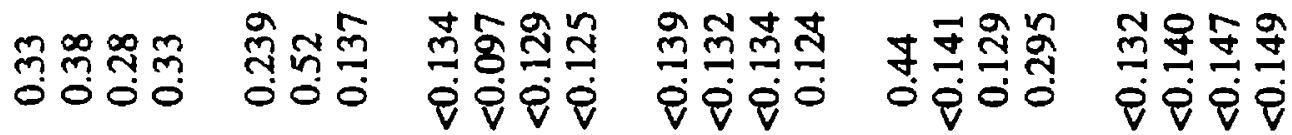

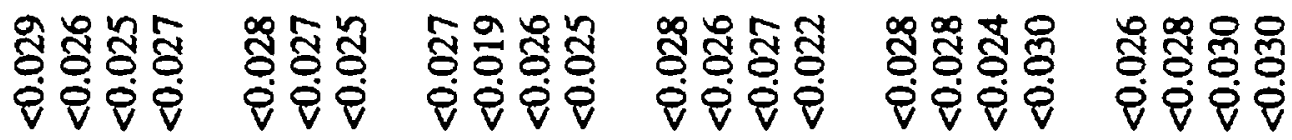

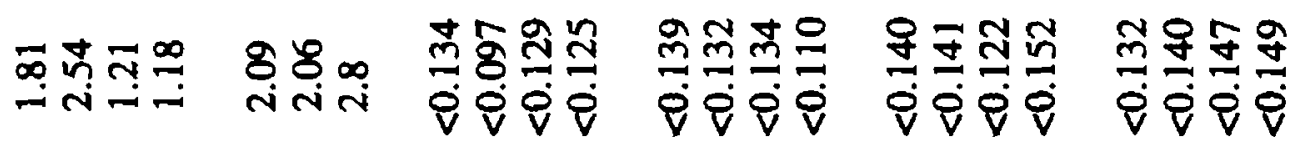

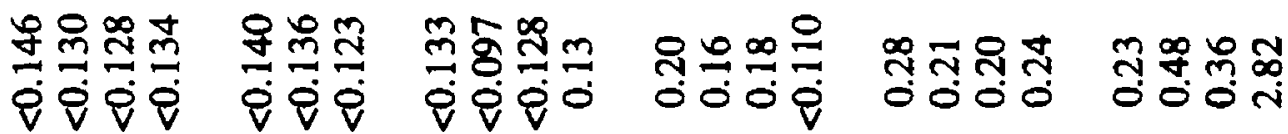

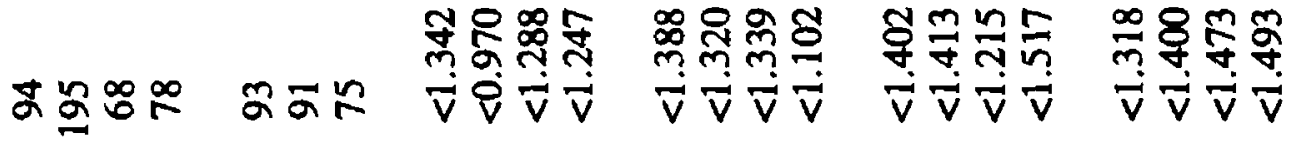

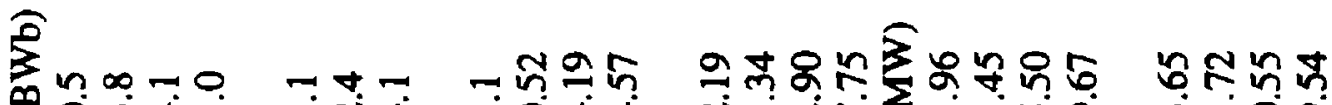

泀参

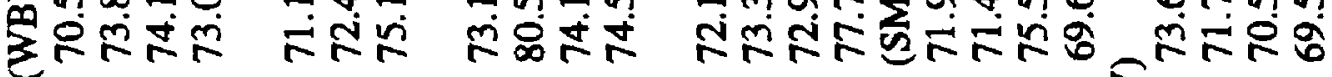

葛点至焉 要

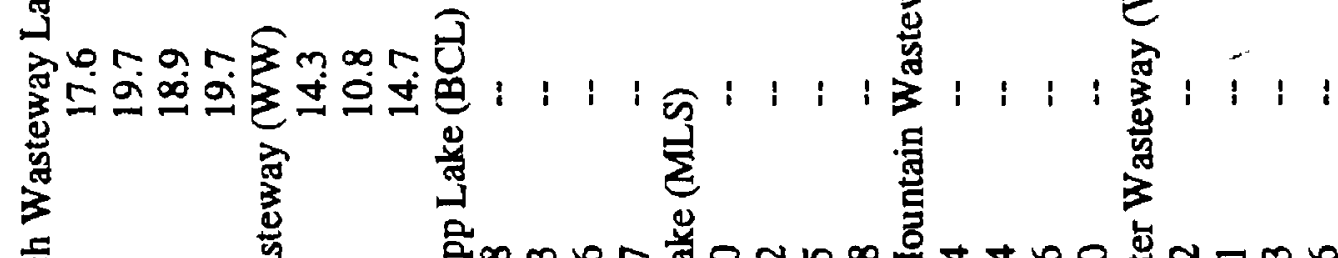

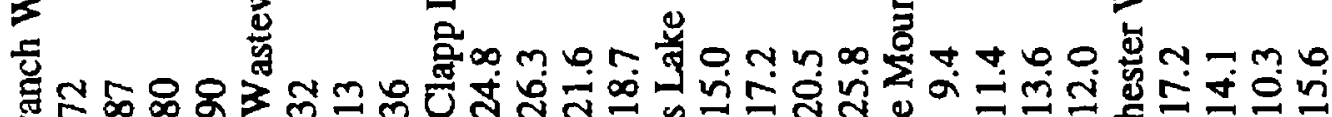

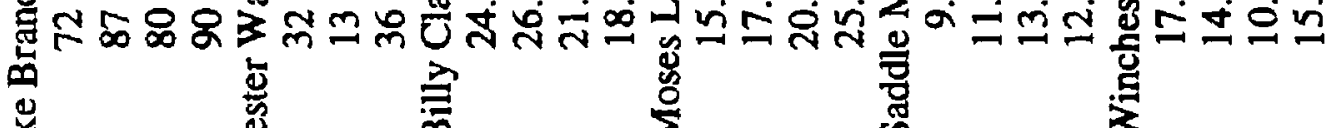
莺

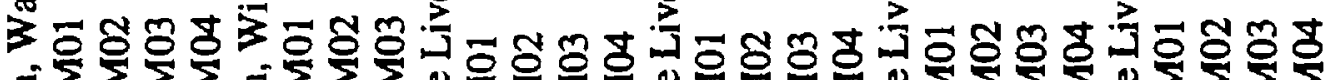

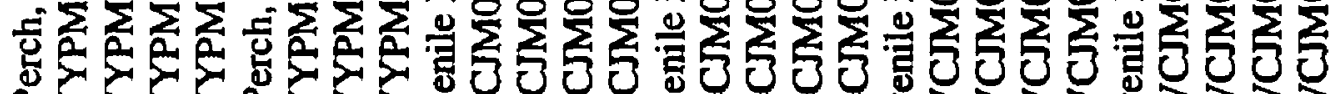

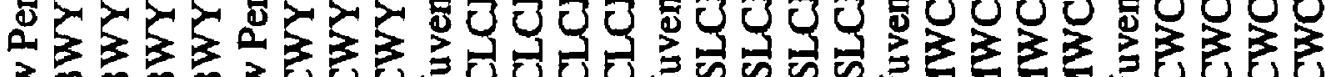

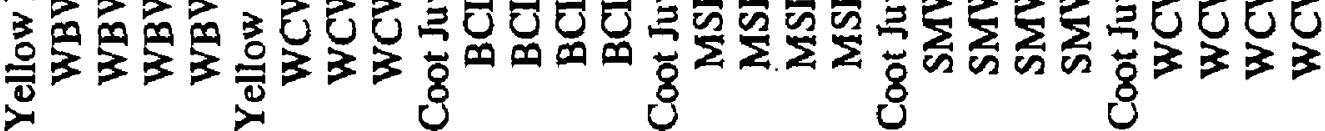




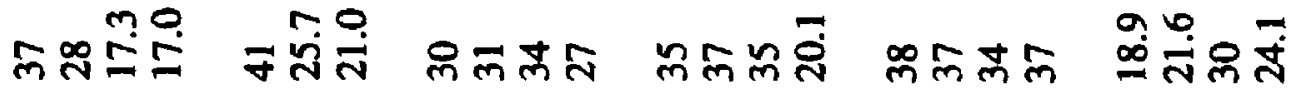

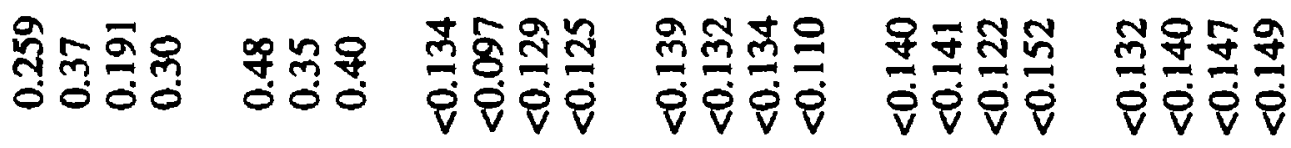

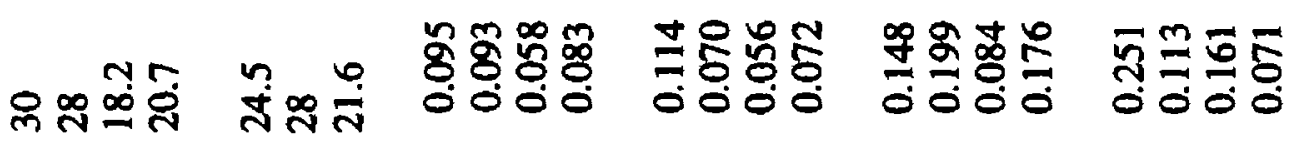

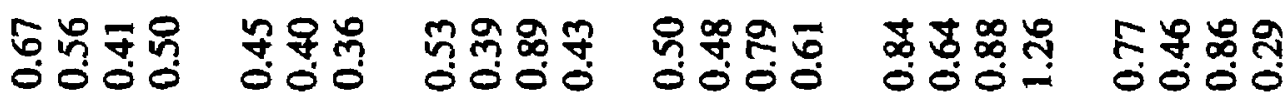

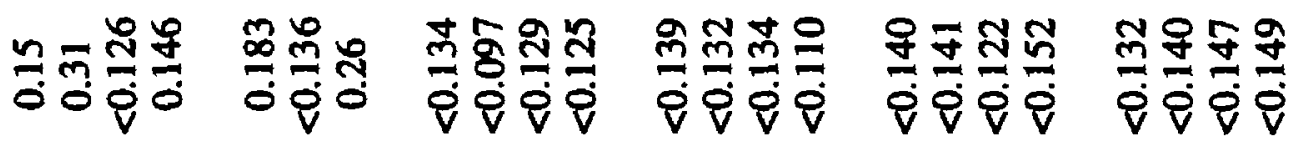

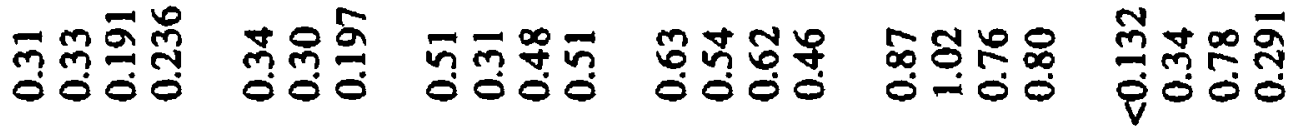

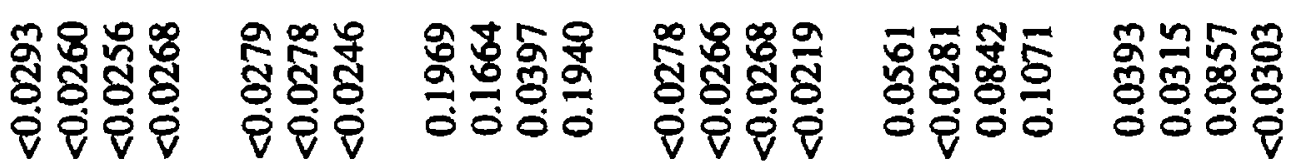

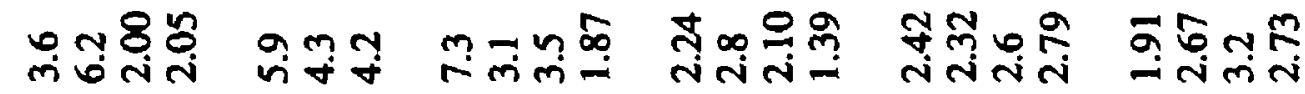

兽

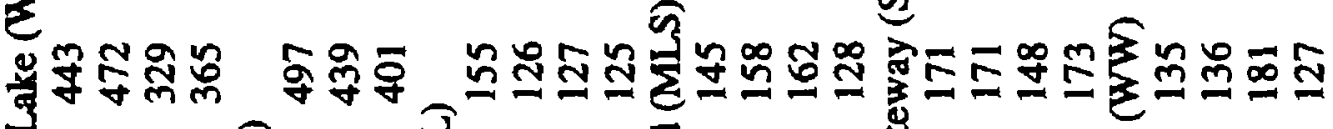
等 


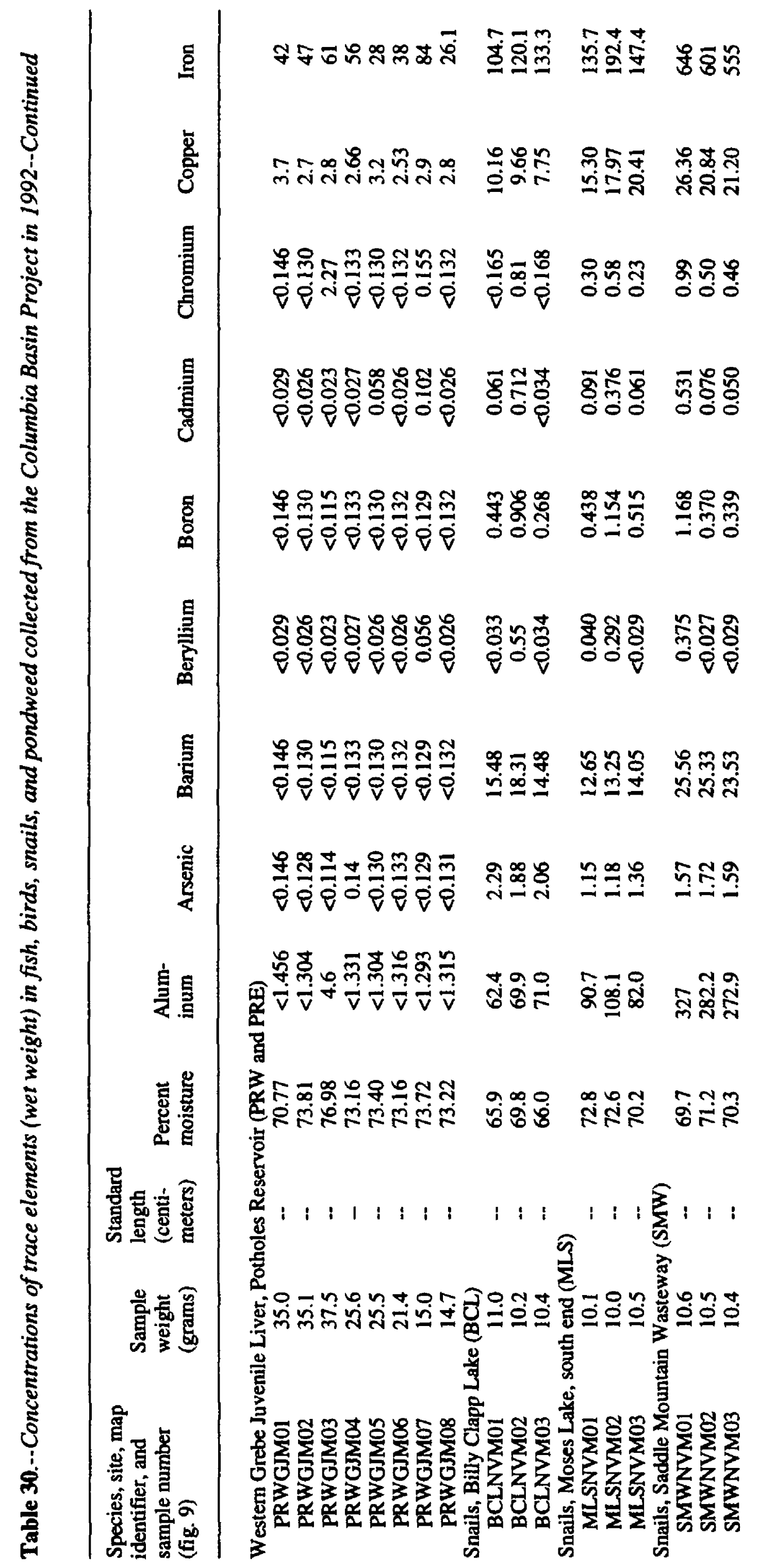




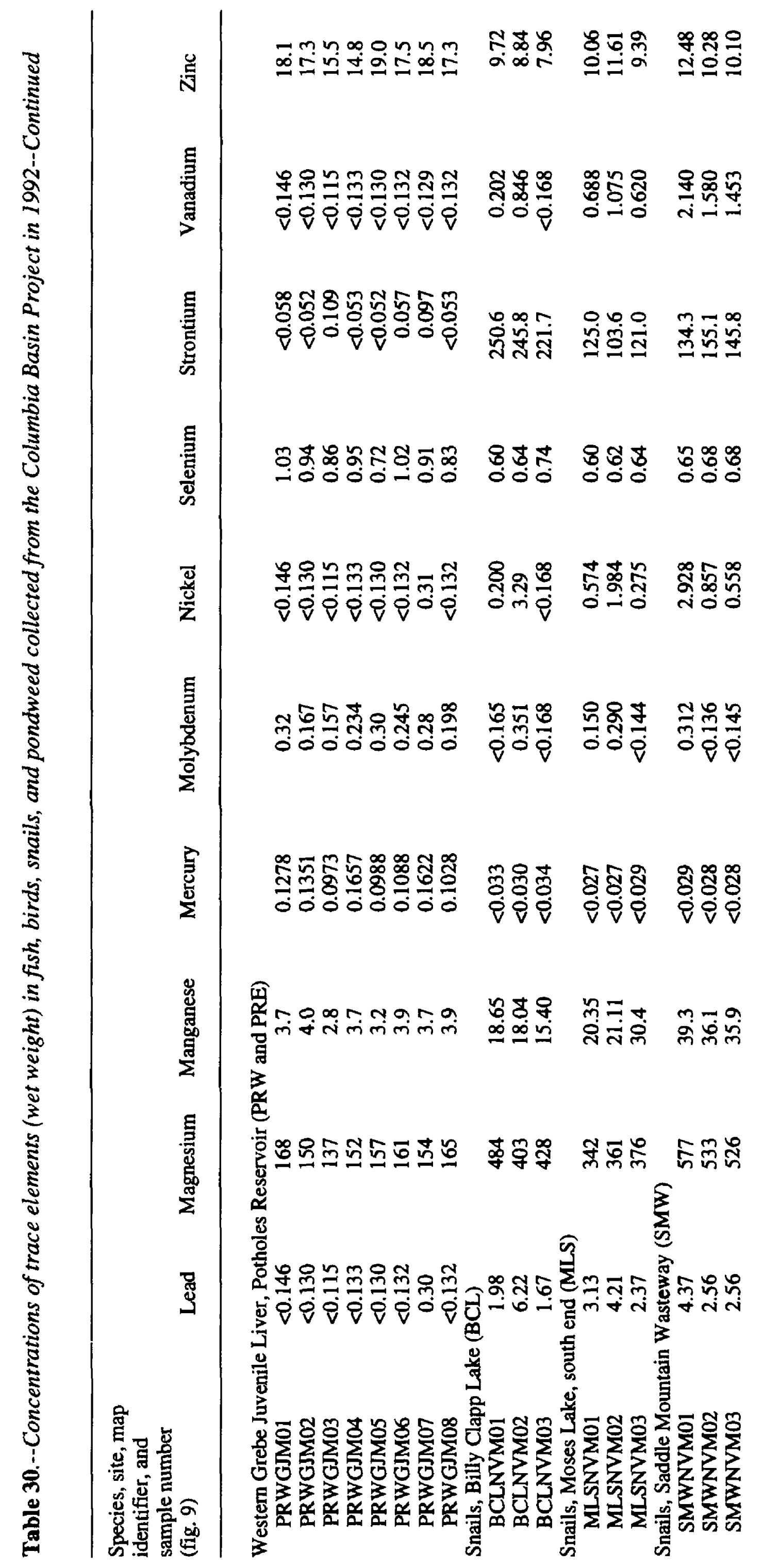




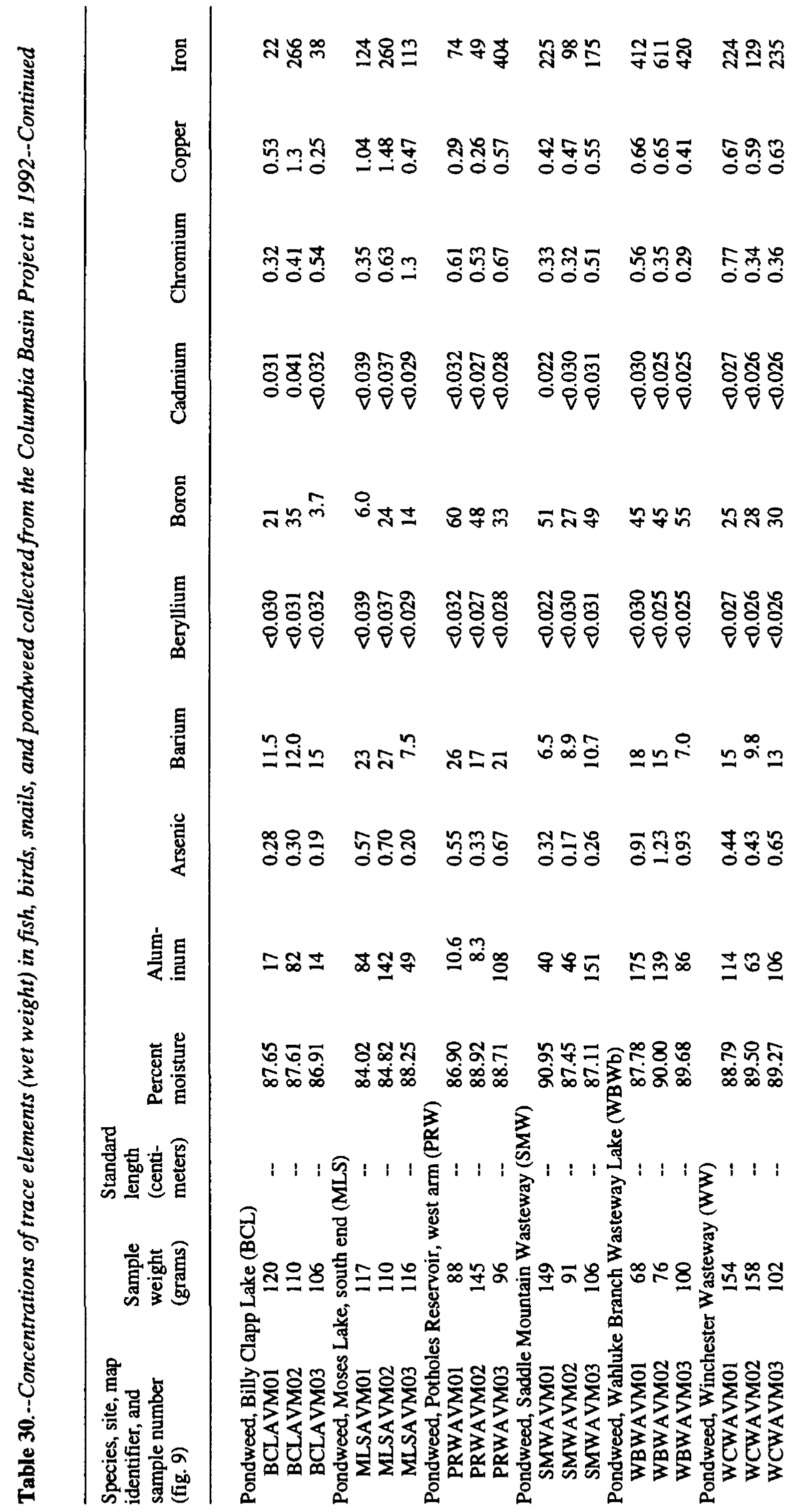




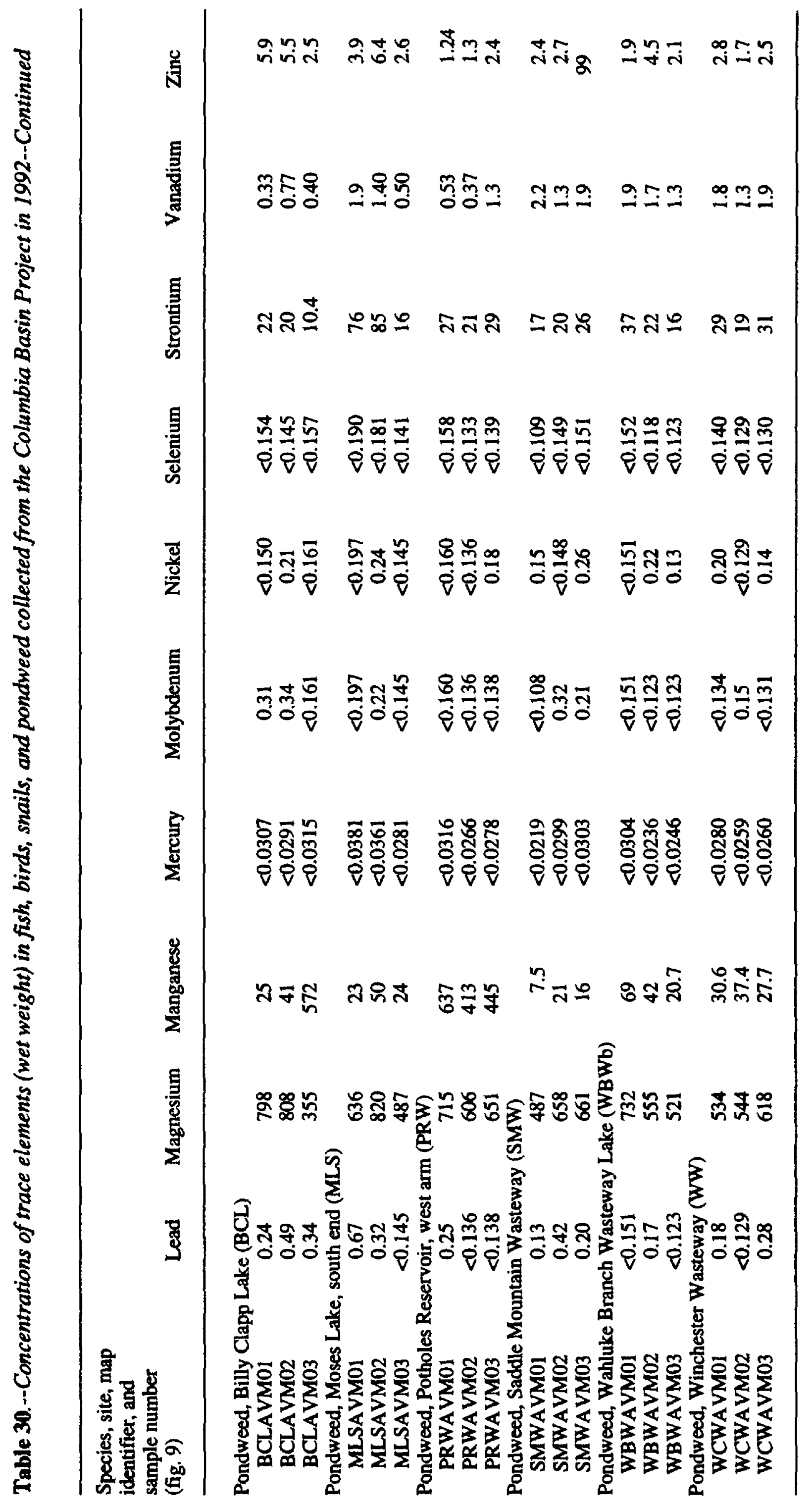




\begin{tabular}{|c|c|c|c|c|c|c|c|}
\hline & 菓 & $\cong \Xi \frac{\infty}{m} \mathcal{I}$ & 공요 & 응호궟 & จิ & 을 & 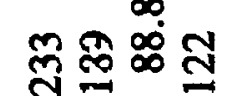 \\
\hline & 这 & 웅 & त̄ & $\begin{array}{l}\infty \\
0 \\
0 \\
0\end{array}$ & 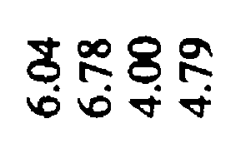 & 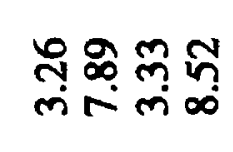 & 꾸워 \\
\hline 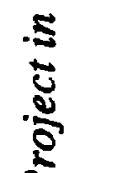 & $\begin{array}{l}\text { 录 } \\
\text { 题 } \\
\end{array}$ & $\begin{array}{l}+ \\
\infty \\
\infty \\
\infty\end{array}$ & 붕 & 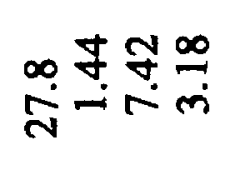 & 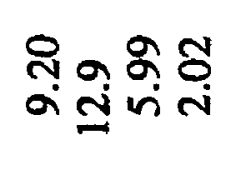 & 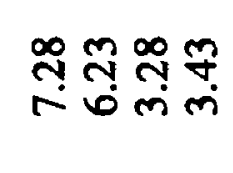 & 꾸ำ \\
\hline $\begin{array}{l}3 \\
0 \\
0 \\
0 \\
0 \\
0\end{array}$ & 覞 & 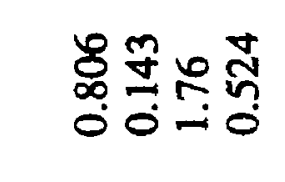 & 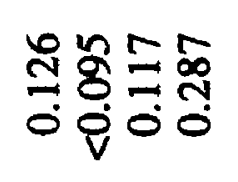 & 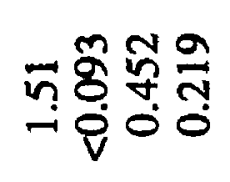 & 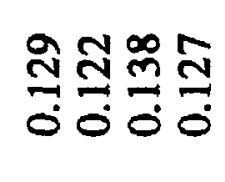 & 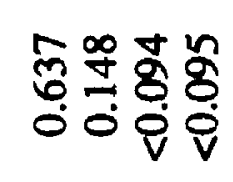 & 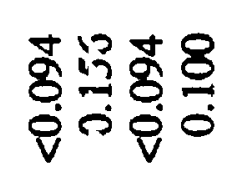 \\
\hline ฐ & 宫 & $\begin{array}{l}\infty \\
0 \\
0 \\
0\end{array}$ & 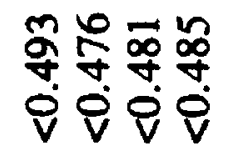 & 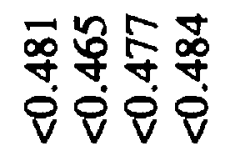 & 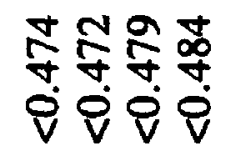 & 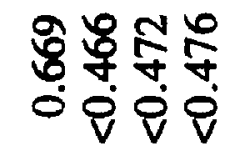 & 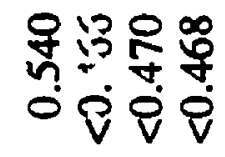 \\
\hline 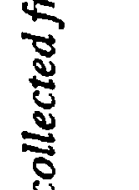 & 具 & 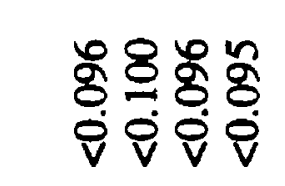 & 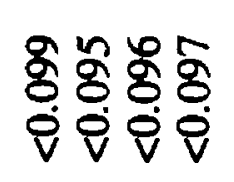 & 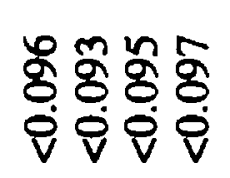 & 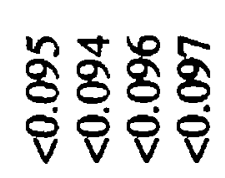 & 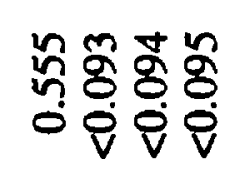 & 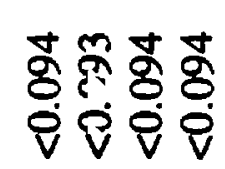 \\
\hline$\frac{5}{8}$ & 昜 & 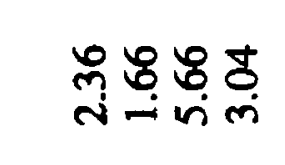 & 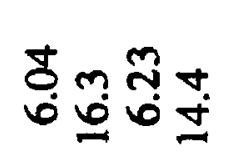 & 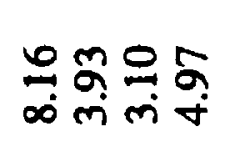 & 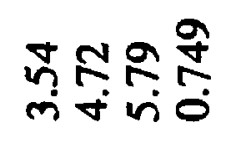 & 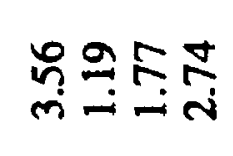 & 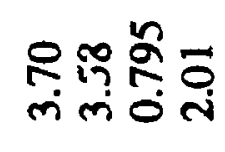 \\
\hline$\frac{5}{\xi}$ & 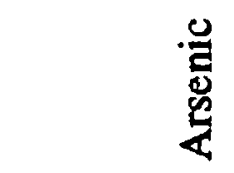 & 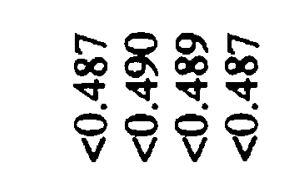 & 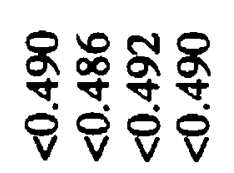 & 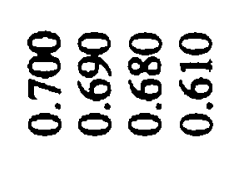 & 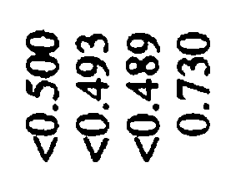 & 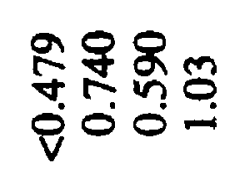 & 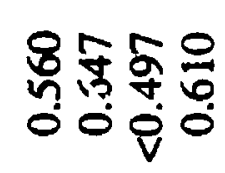 \\
\hline 点 & 总罡 & 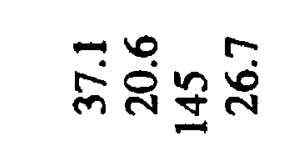 & 으ำทั่ & 원응 $\frac{9}{\infty}$ & 용요 & 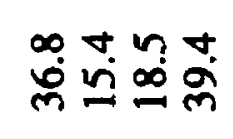 & mân \\
\hline 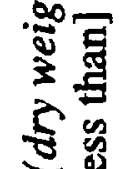 & 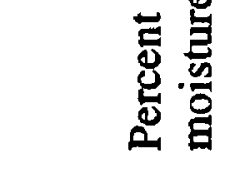 & 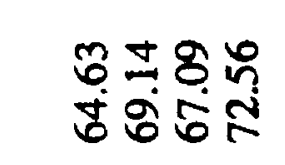 & 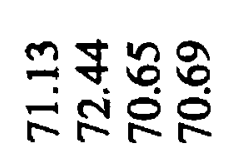 & 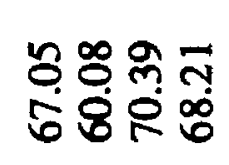 & 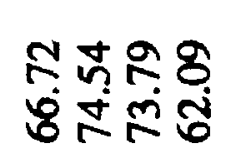 & 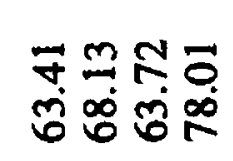 & 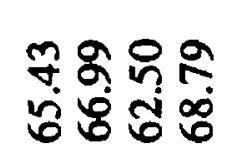 \\
\hline 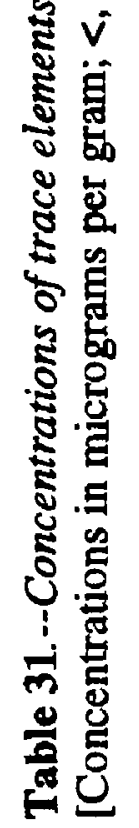 & 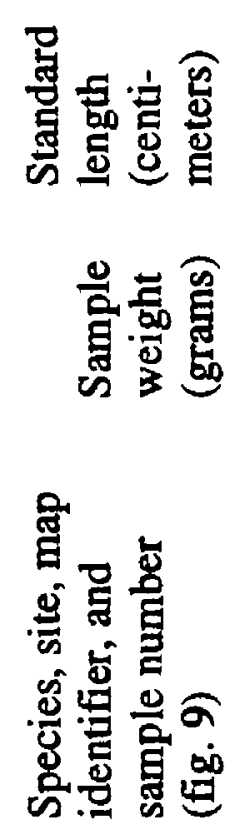 & 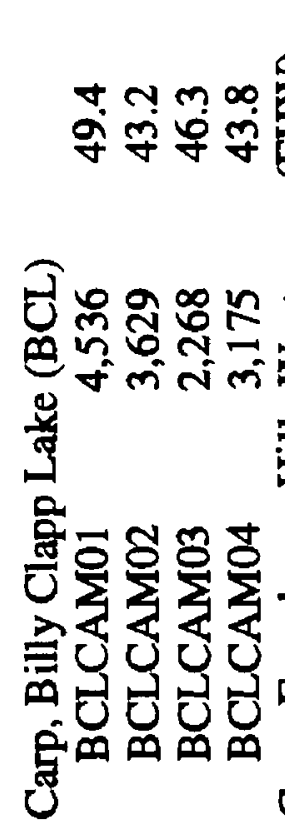 & 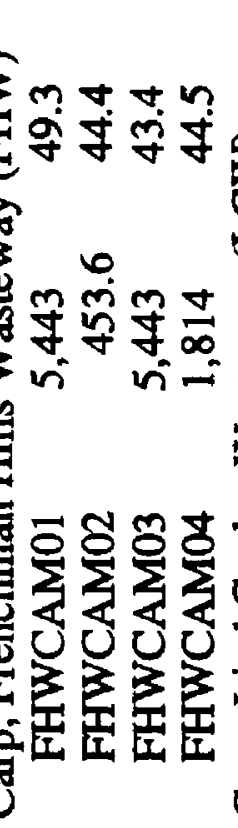 & 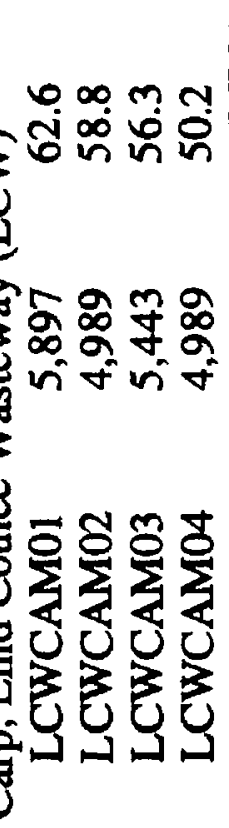 & 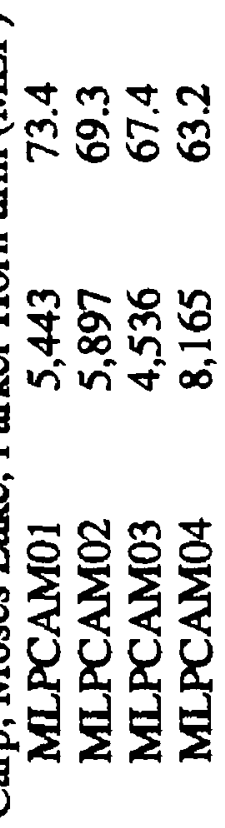 & 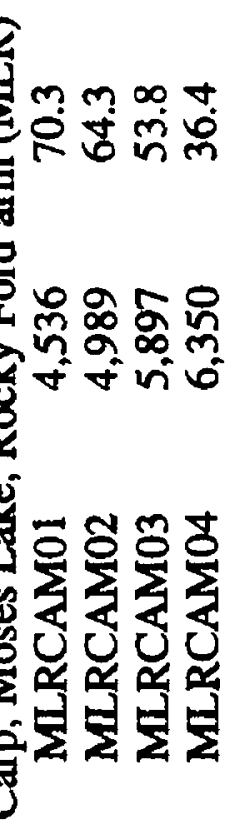 & 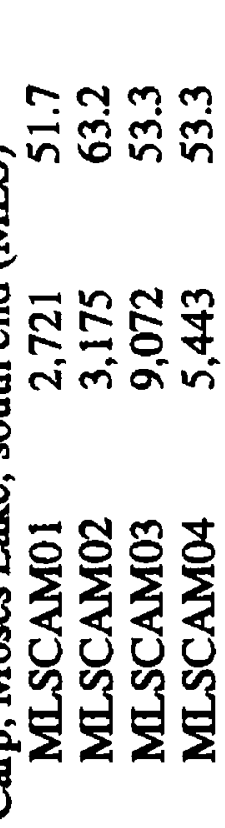 \\
\hline
\end{tabular}




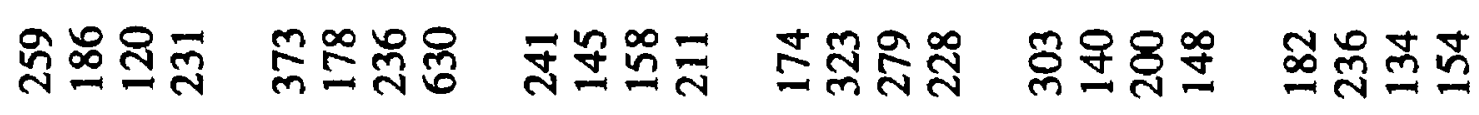

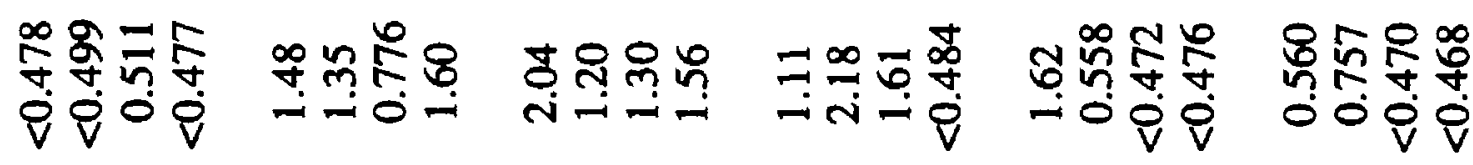

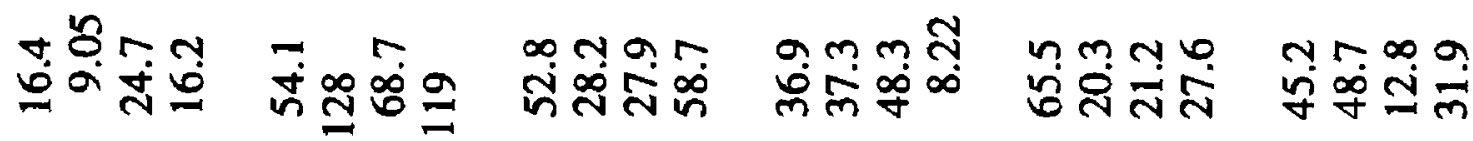

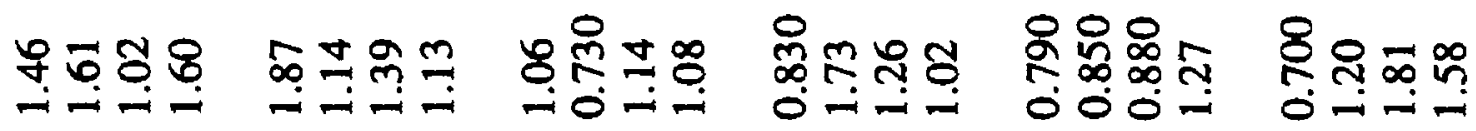

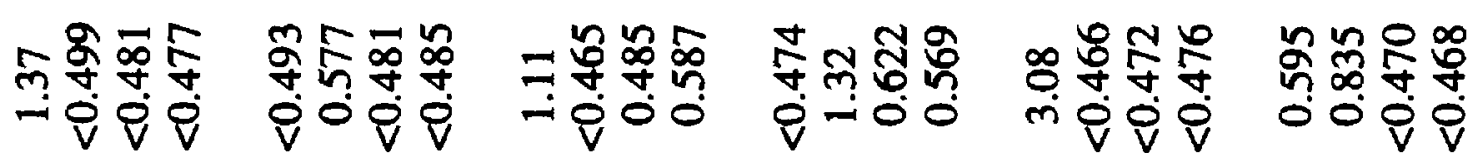

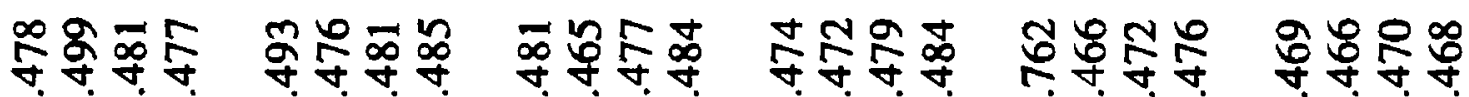
割守

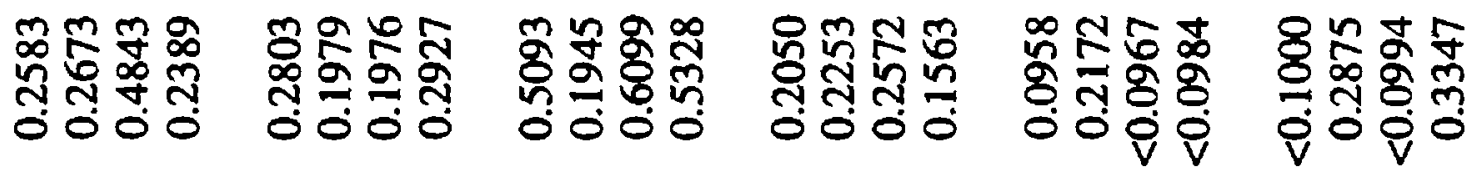

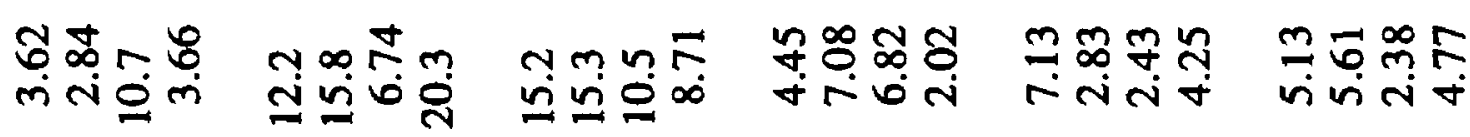

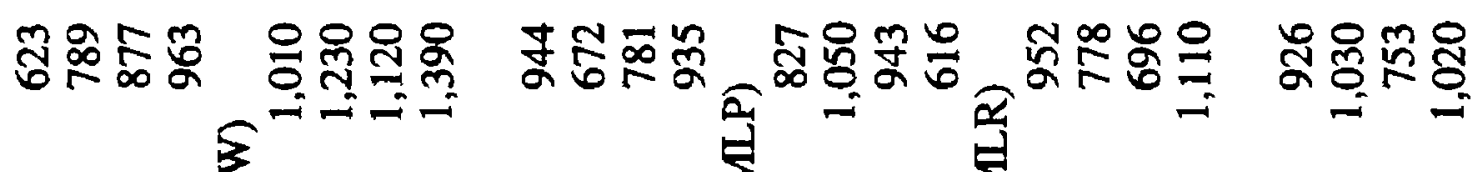
密

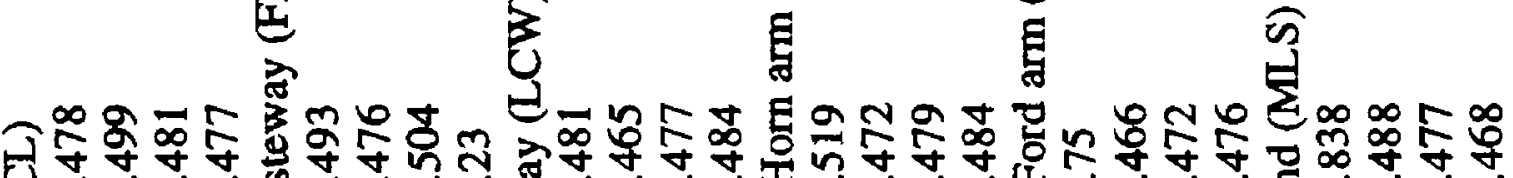
êvं

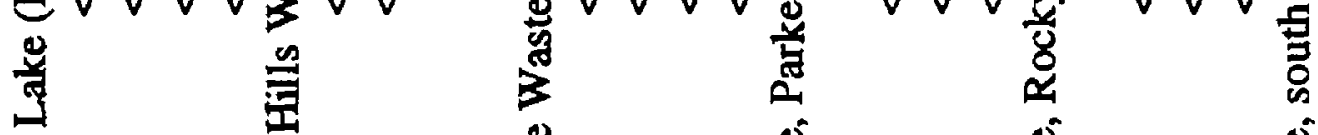

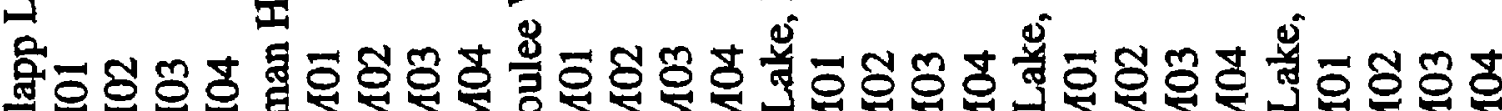

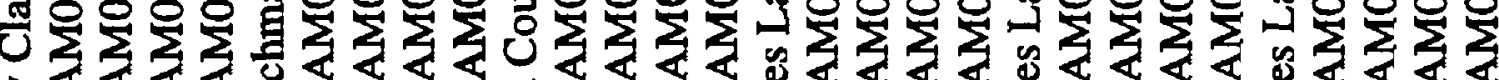
ฉ<์ 望U U

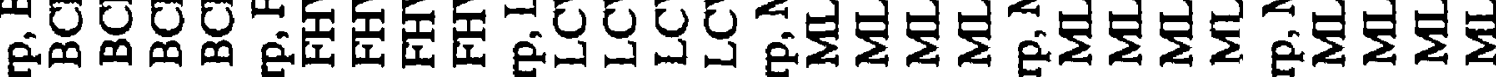
ฮั

(1)

蹇 


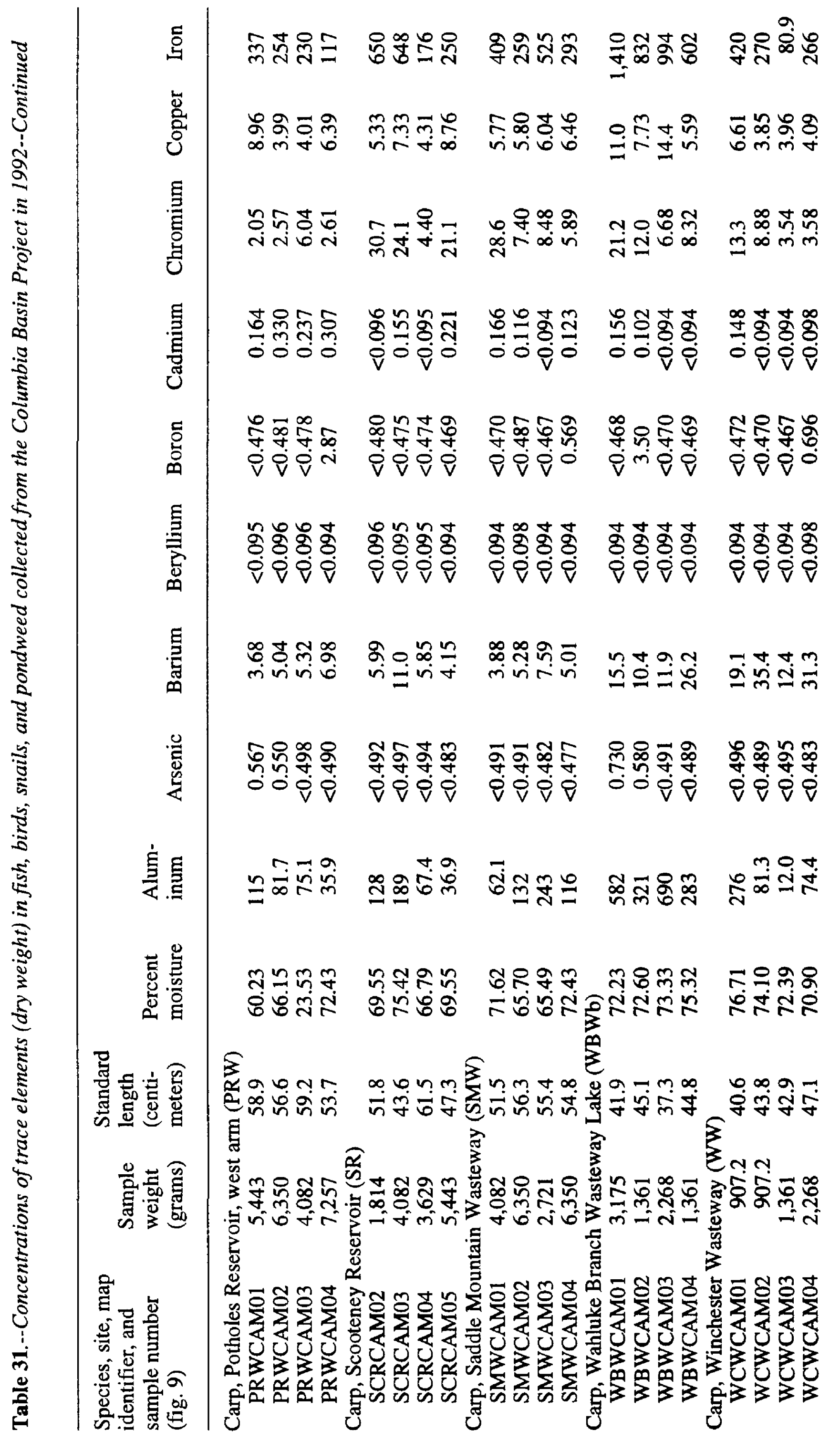




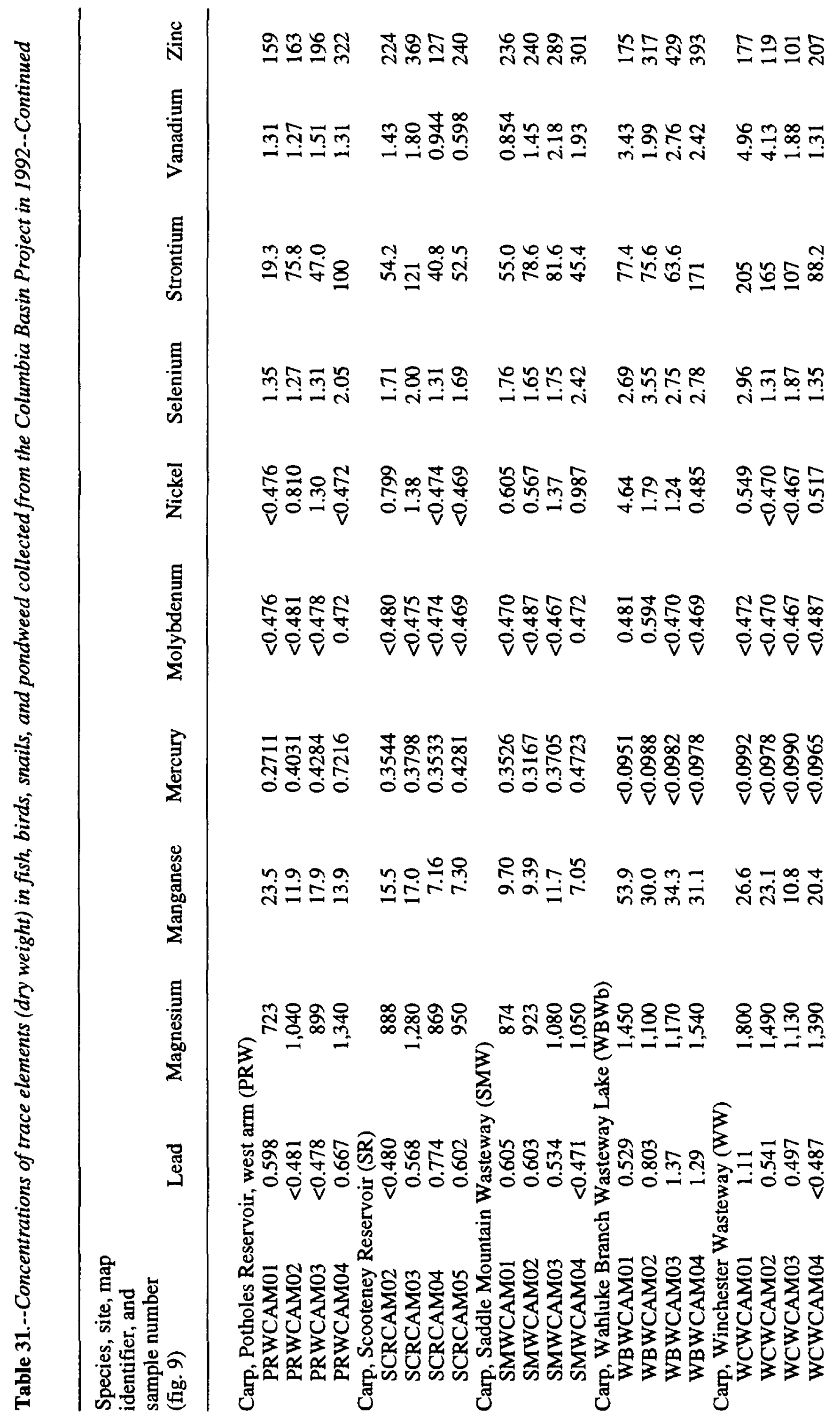




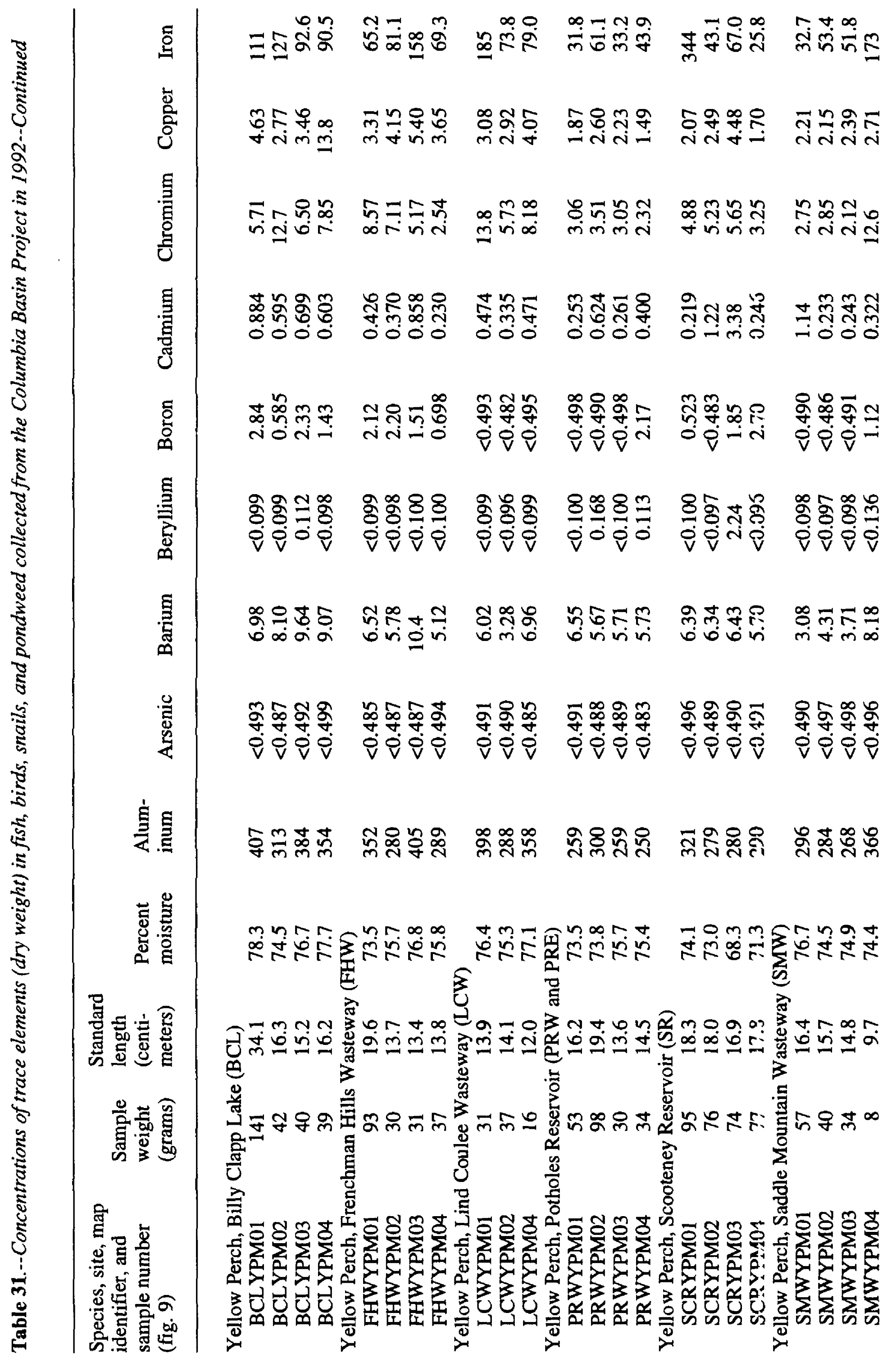




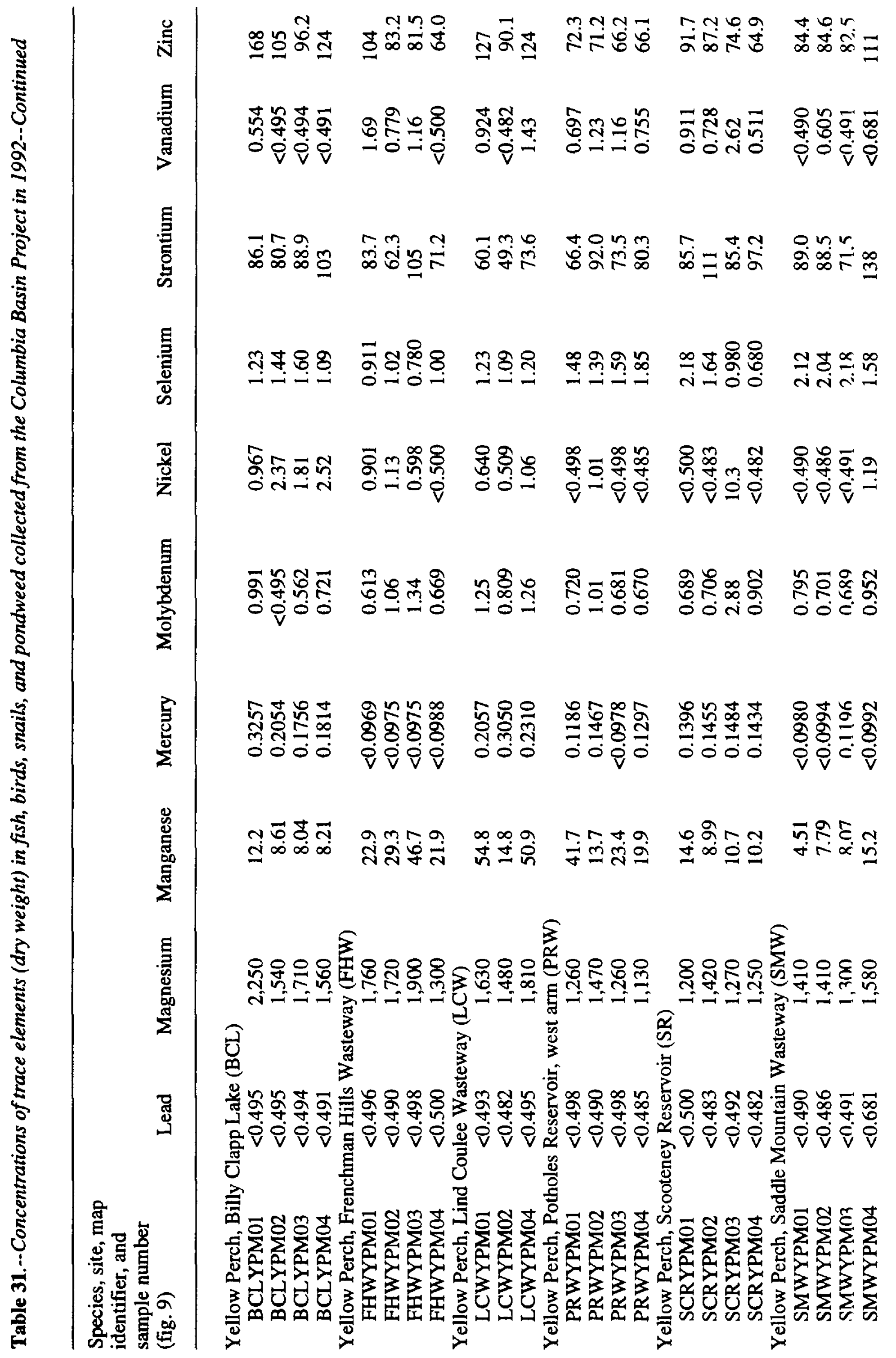




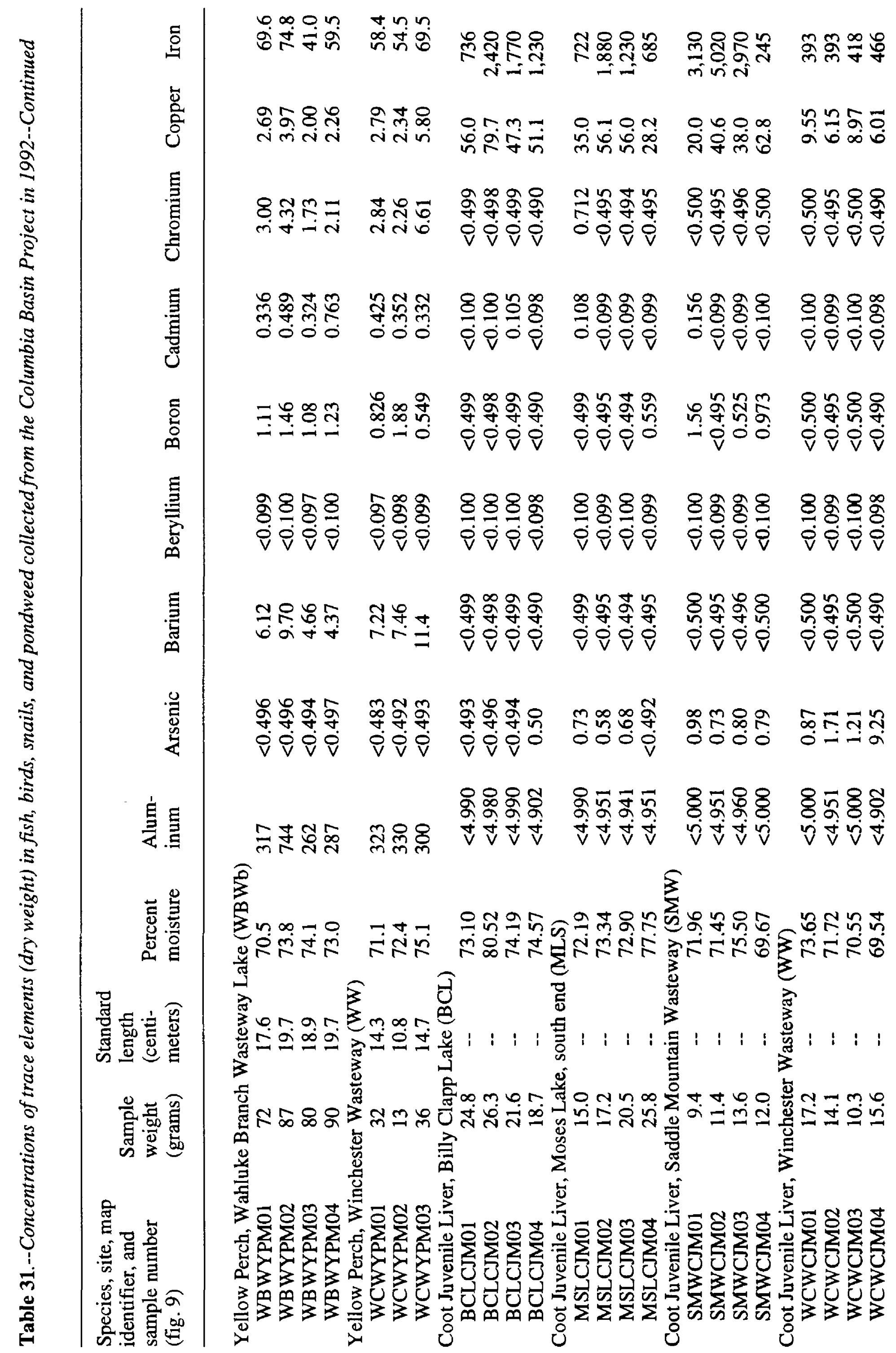




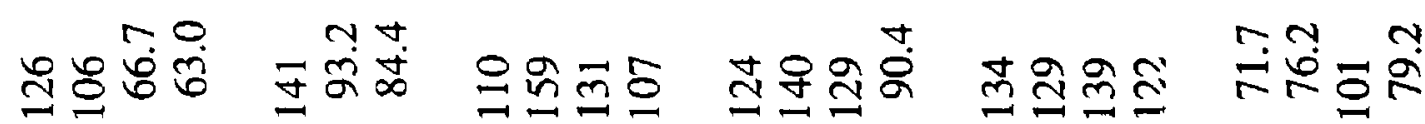

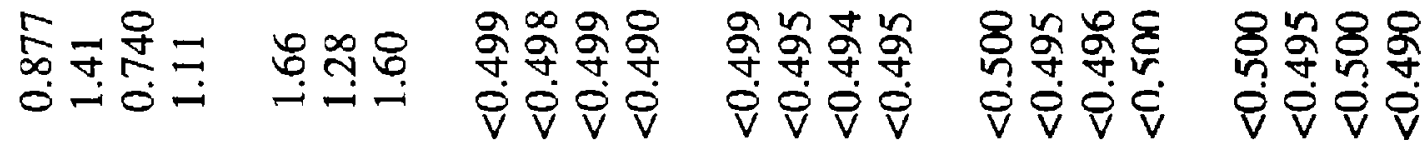

营

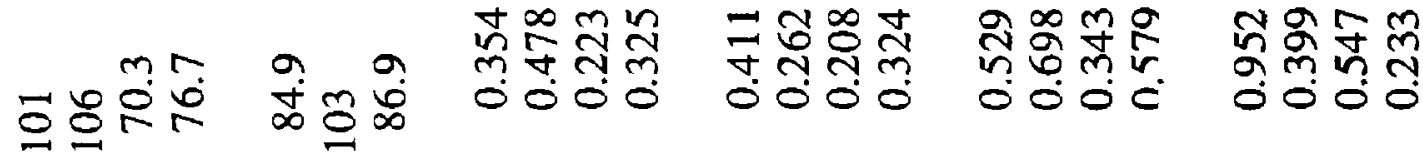

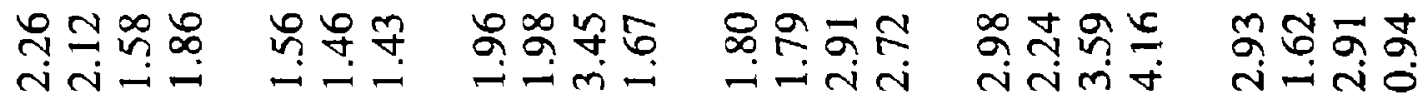

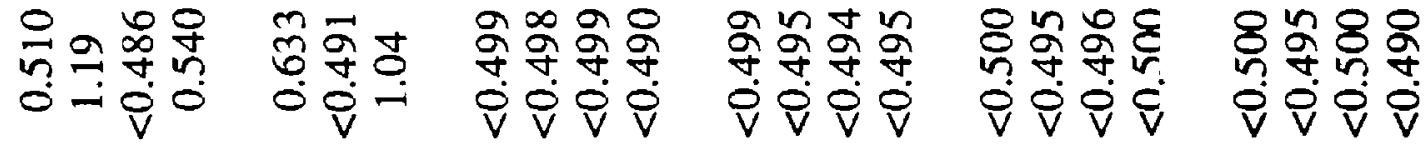

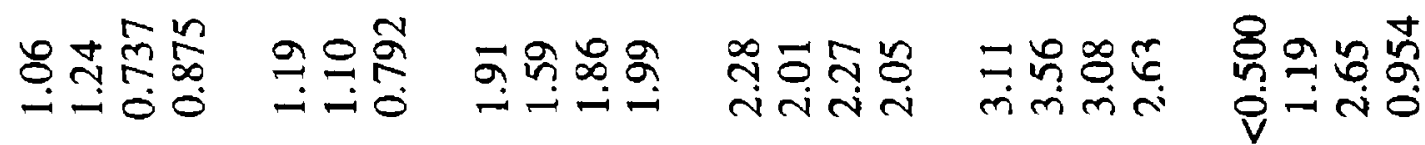

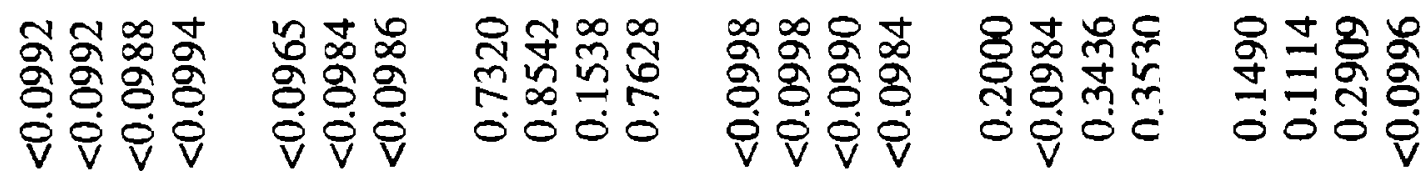

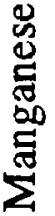

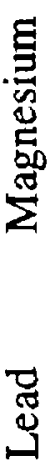

$v \nabla$

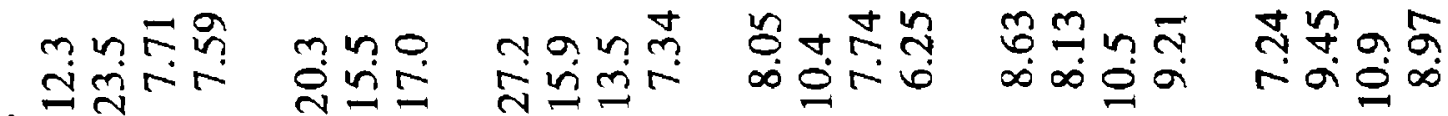
$\sum_{3}^{\infty}$

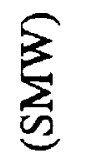

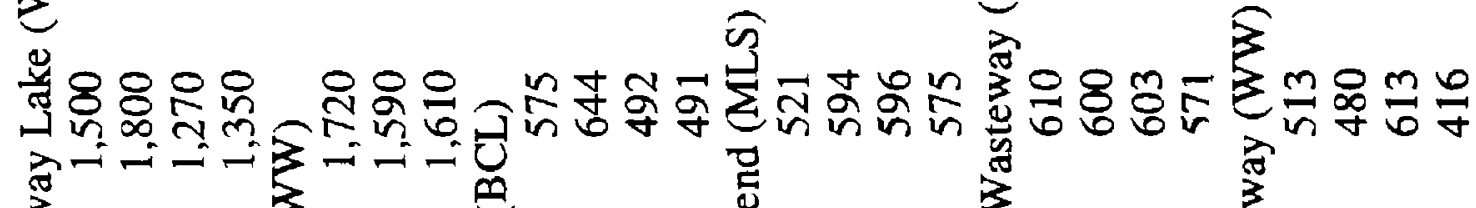
要 


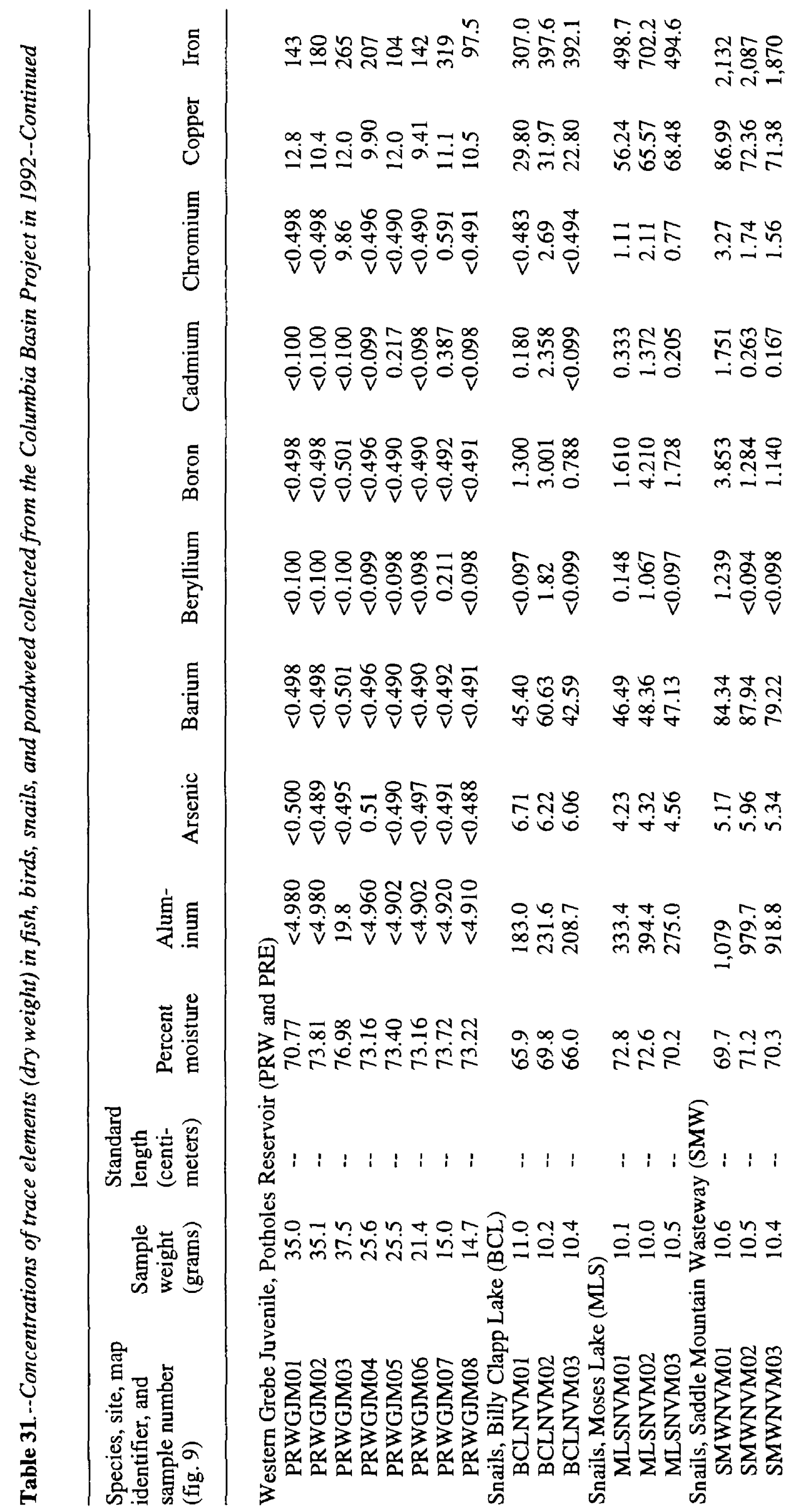




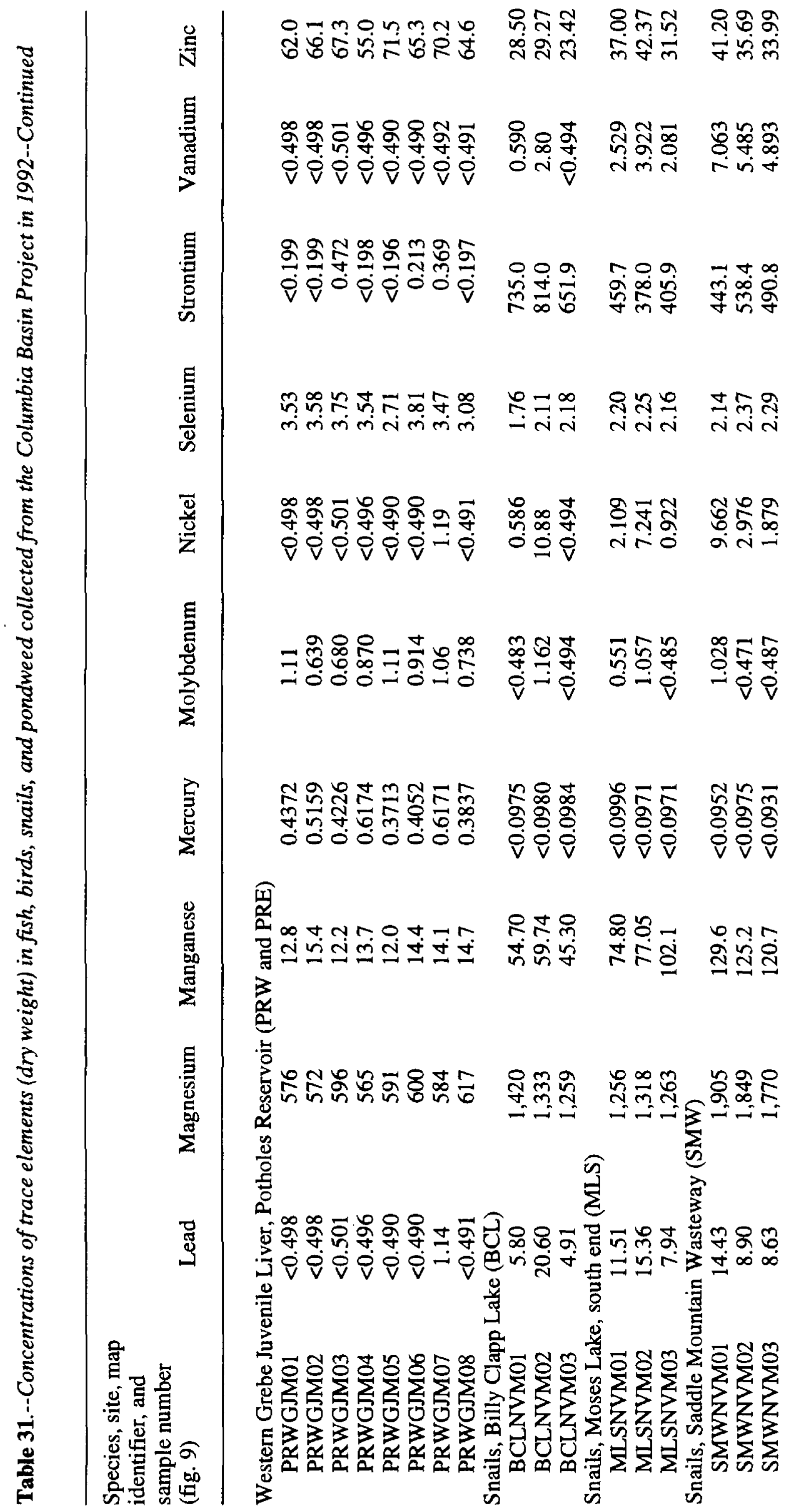




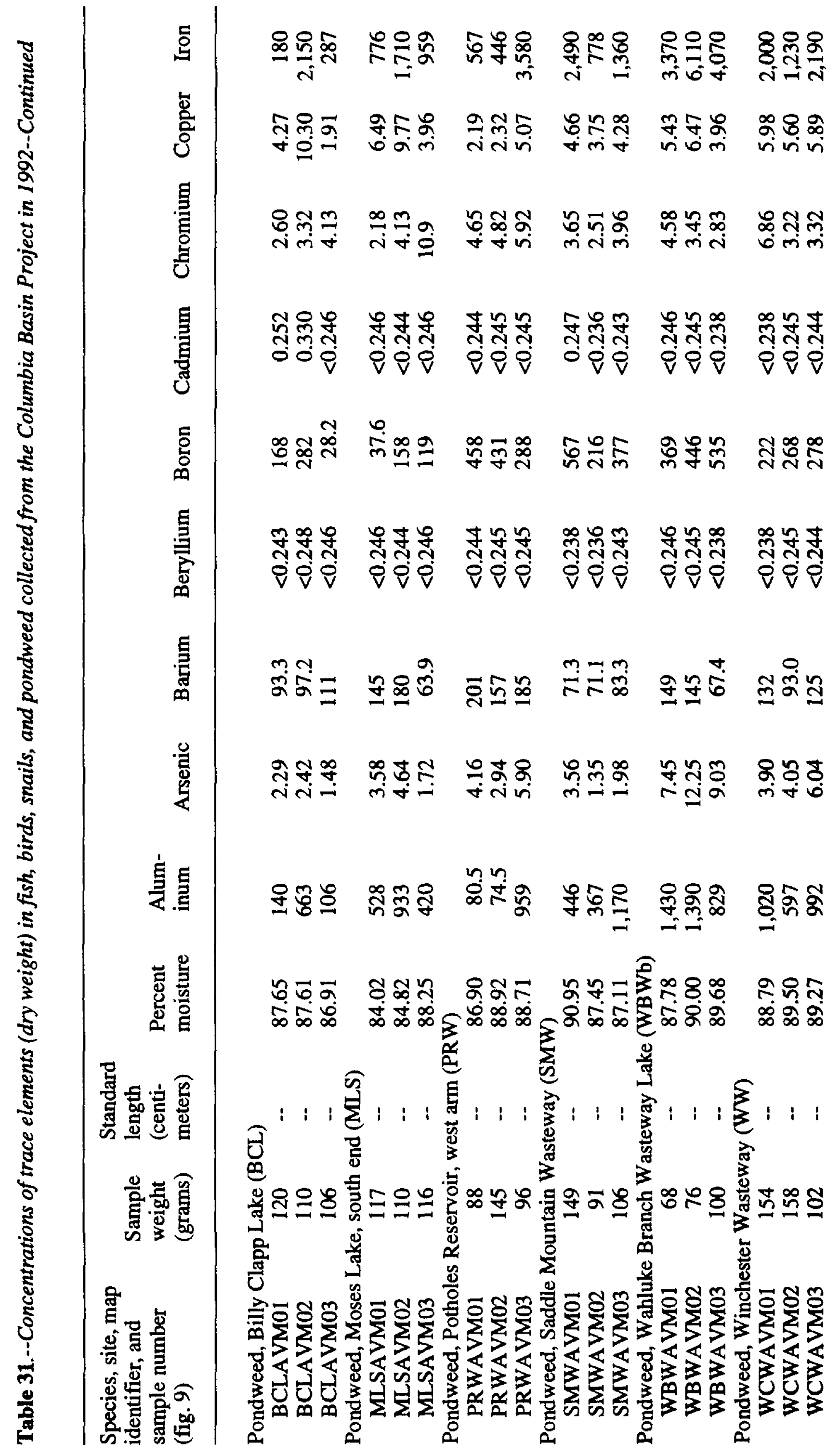




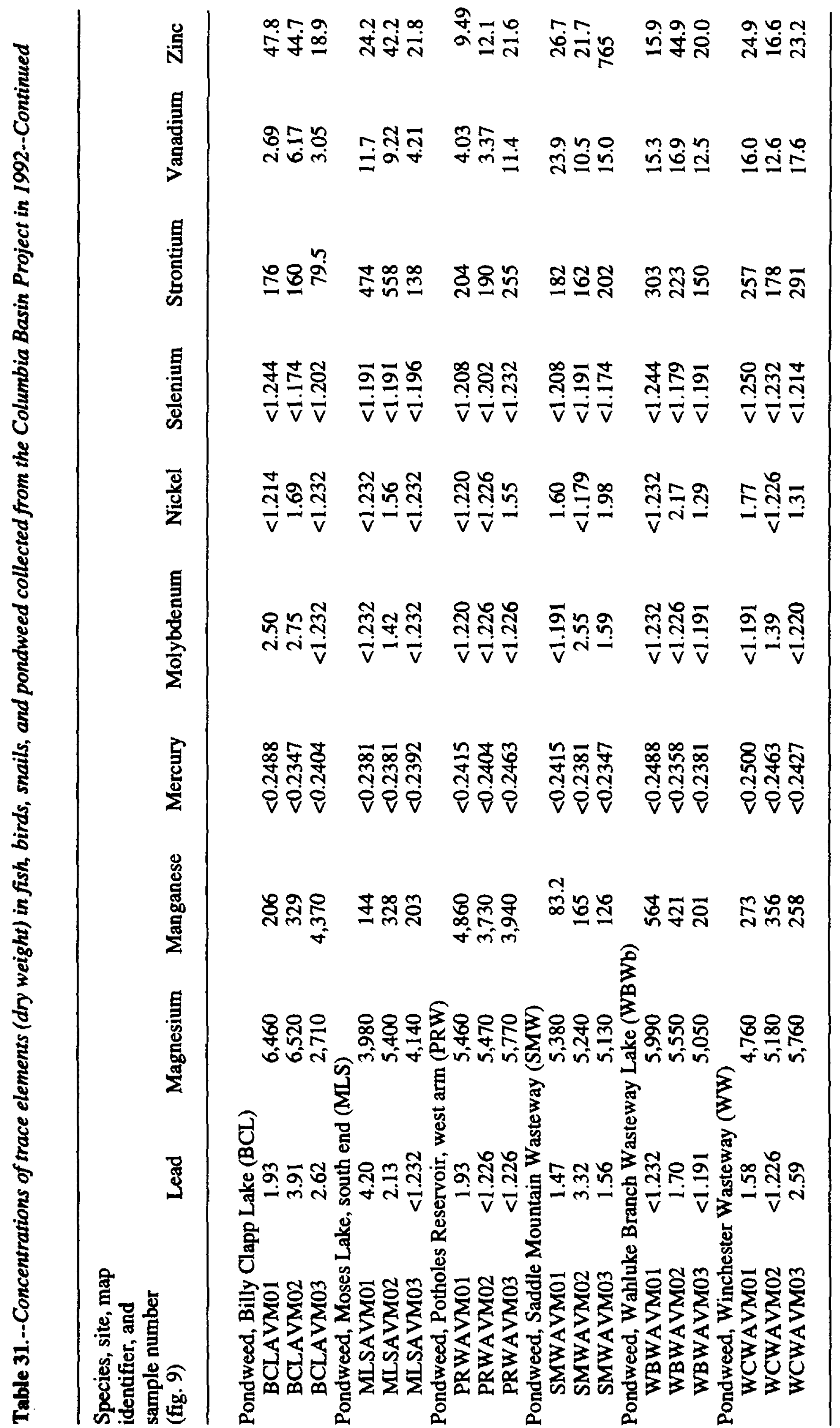


Table 32.--Concentrations of trace elements in bird eggs collected from the Columbia Basin Project in 1992

[Concentrations in micrograms per gram; <, less than]

Species, site, map

identifier, and

Sample

sample number

(fig. 9)

\section{weight}

Percent

Wet Weight

(grams)

moisture

Arsenic Mercury

Selenium Arsenic Mercury

Selenium

Coot Eggs, Billy Clapp Lake (BCL)

$\begin{array}{lllllllll}\text { BCLCEM01 } & 24.53 & 74.36 & 0.09 & <0.0256 & 0.34 & 0.33 & <0.1 & 1.31 \\ \text { BCLCEM02 } & 22.45 & 73.54 & 0.137 & 0.0482 & 0.37 & 0.516 & 0.1822 & 1.41 \\ \text { BCLCEM03 } & 27.32 & 74.85 & <0.075 & 0.0316 & 0.30 & <0.298 & 0.1255 & 1.21 \\ \text { BCLCEM04 } & 27.55 & 73.54 & <0.078 & 0.0349 & 0.29 & <0.296 & 0.1318 & 1.09\end{array}$

Coot Eggs, Moses Lake, south end (MLS)

$\begin{array}{llllclccl}\text { MLSCEM01 } & 19.75 & 74.28 & <0.077 & <0.0257 & 0.39 & <0.3 & <0.1 & 1.50 \\ \text { MLSCEM02 } & 29.03 & 74.85 & 0.119 & 0.0634 & 0.42 & 0.473 & 0.2521 & 1.67 \\ \text { MLSCEM03 } & 24.35 & 73.06 & <0.090 & 0.107 & 0.47 & <0.334 & 0.398 & 1.75 \\ \text { MLSCEM04 } & 26.88 & 73.70 & <0.077 & <0.0256 & 0.39 & <0.292 & <0.0975 & 1.48\end{array}$

Coot Eggs, Saddle Mountain Wasteway (SMW)

$\begin{array}{llrrrrrrr}\text { SMWCEM01 } & 27.11 & 74.95 & 0.118 & <0.0251 & 0.57 & 0.47 & <0.1 & 2.29 \\ \text { SMWCEM02 } & 23.37 & 76.55 & <0.070 & 0.0513 & 0.50 & <0.299 & 0.2186 & 2.11 \\ \text { SMWCEM03 } & 27.07 & 76.25 & 0.114 & 0.0268 & 0.57 & 0.48 & 0.1127 & 2.41 \\ \text { SMWCEM04 } & 24.81 & 74.53 & 0.147 & <0.0250 & 0.31 & 0.58 & <0.0982 & 1.22\end{array}$

Coot Eggs, Winchester Wasteway (WW)

$\begin{array}{llllrlrrr}\text { WCWCEM01 } & 19.63 & 77.43 & 0.08 & 0.0776 & 0.49 & 0.36 & 0.3439 & 2.16 \\ \text { WCWCEM02 } & 23.44 & 75.55 & 0.088 & <0.0243 & 0.59 & 0.36 & <0.0992 & 2.43 \\ \text { WCWCEM03 } & 24.17 & 75.18 & <0.072 & 0.0457 & 0.54 & <0.292 & 0.1841 & 2.17 \\ \text { WCWCEM04 } & 30.43 & 73.84 & <0.077 & <0.0258 & 0.54 & <0.296 & <0.0986 & 2.05\end{array}$

Mallard Eggs, Moses Lake, south end (MLS)

$\begin{array}{lllllllll}\text { MLSMEM01 } & 45.04 & 67.50 & <0.097 & <0.0322 & 0.67 & <0.297 & <0.099 & 2.07 \\ \text { MLSMEM02 } & 43.93 & 68.31 & <0.093 & <0.0311 & 0.44 & <0.294 & <0.098 & 1.40 \\ \text { MLSMEM03 } & 41.36 & 65.47 & <0.102 & <0.0338 & 0.59 & <0.294 & <0.098 & 1.72 \\ \text { MLSMEM04 } & 36.43 & 68.38 & <0.093 & <0.0311 & 0.70 & <0.295 & <0.0984 & 2.20 \\ \text { MLSMEM05 } & 41.31 & 66.42 & <0.099 & <0.0329 & 0.47 & <0.295 & <0.0982 & 1.40\end{array}$

Western Grebe Eggs, Potholes Reservoir, east arm (PRE)

$\begin{array}{lrrrrrrrr}\text { PREGEM01 } & 42.21 & 77.30 & 0.087 & 0.0933 & <0.11 & 0.381 & 0.4112 & <0.50 \\ \text { PREGEM02 } & 44.48 & 77.29 & <0.066 & 0.0961 & 0.58 & <0.290 & 0.4231 & 2.54 \\ \text { PREGEM03 } & 34.88 & 75.37 & <0.072 & 0.1088 & <0.12 & <0.291 & 0.4417 & <0.49 \\ \text { PREGEM04 } & 40.12 & 76.10 & <0.072 & 0.0904 & 0.88 & <0.301 & 0.3781 & 3.68\end{array}$

Western Grebe Eggs, Potholes Reservoir, west arm (PRW)

$\begin{array}{lllllllll}\text { PRWGEM01 } & 39.06 & 78.01 & <0.066 & 0.0555 & 0.63 & <0.298 & 0.2524 & 2.84 \\ \text { PRWGEM02 } & 43.36 & 76.52 & <0.071 & 0.0809 & 0.89 & <0.301 & 0.3446 & 3.78 \\ \text { PRWGEM03 } & 40.04 & 79.20 & <0.062 & 0.0676 & 0.89 & <0.299 & 0.3251 & 4.28 \\ \text { PRWGEM04 } & 42.87 & 77.49 & <0.067 & 0.0650 & 0.60 & <0.299 & 0.2889 & 2.67\end{array}$




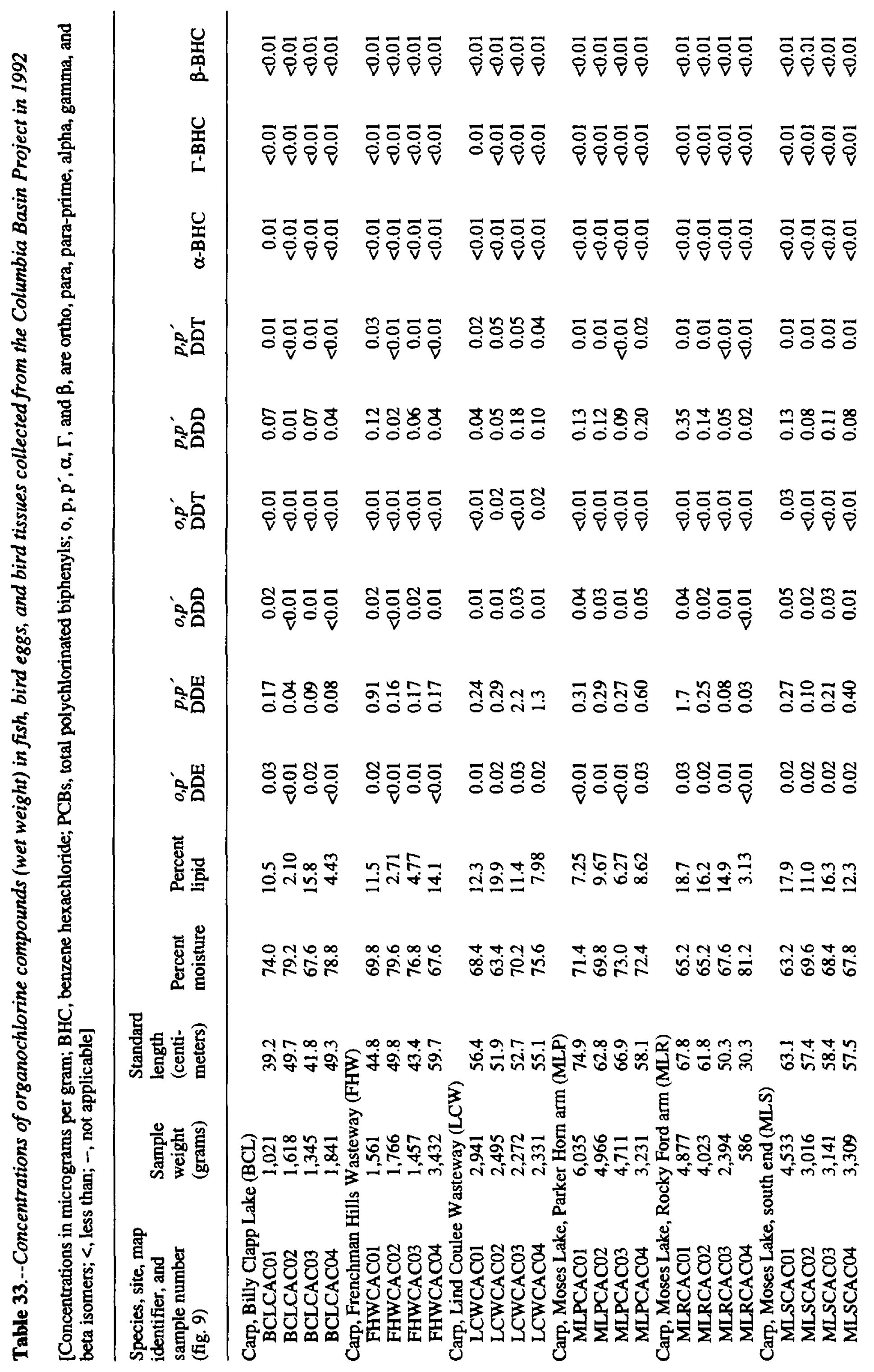




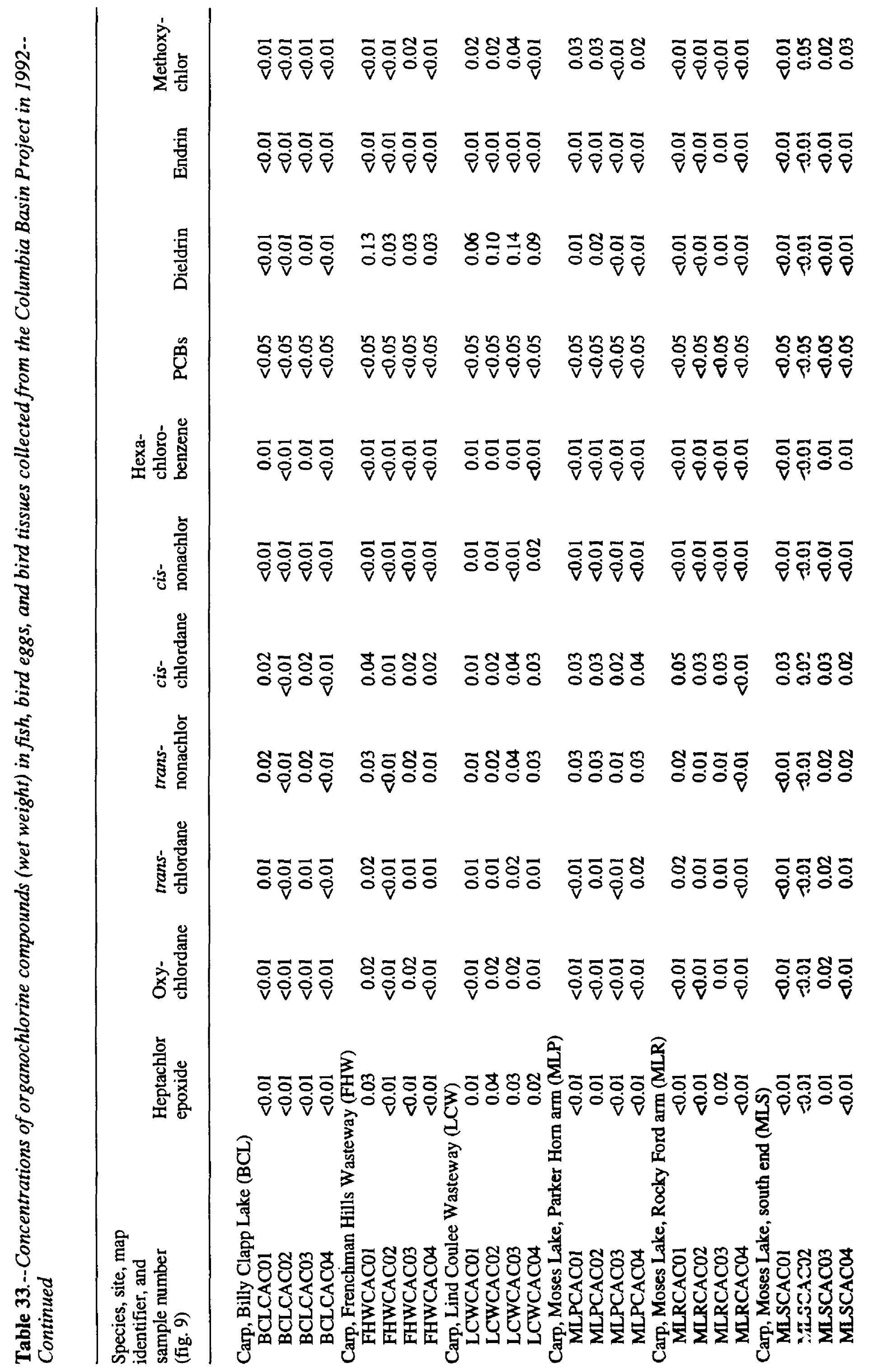




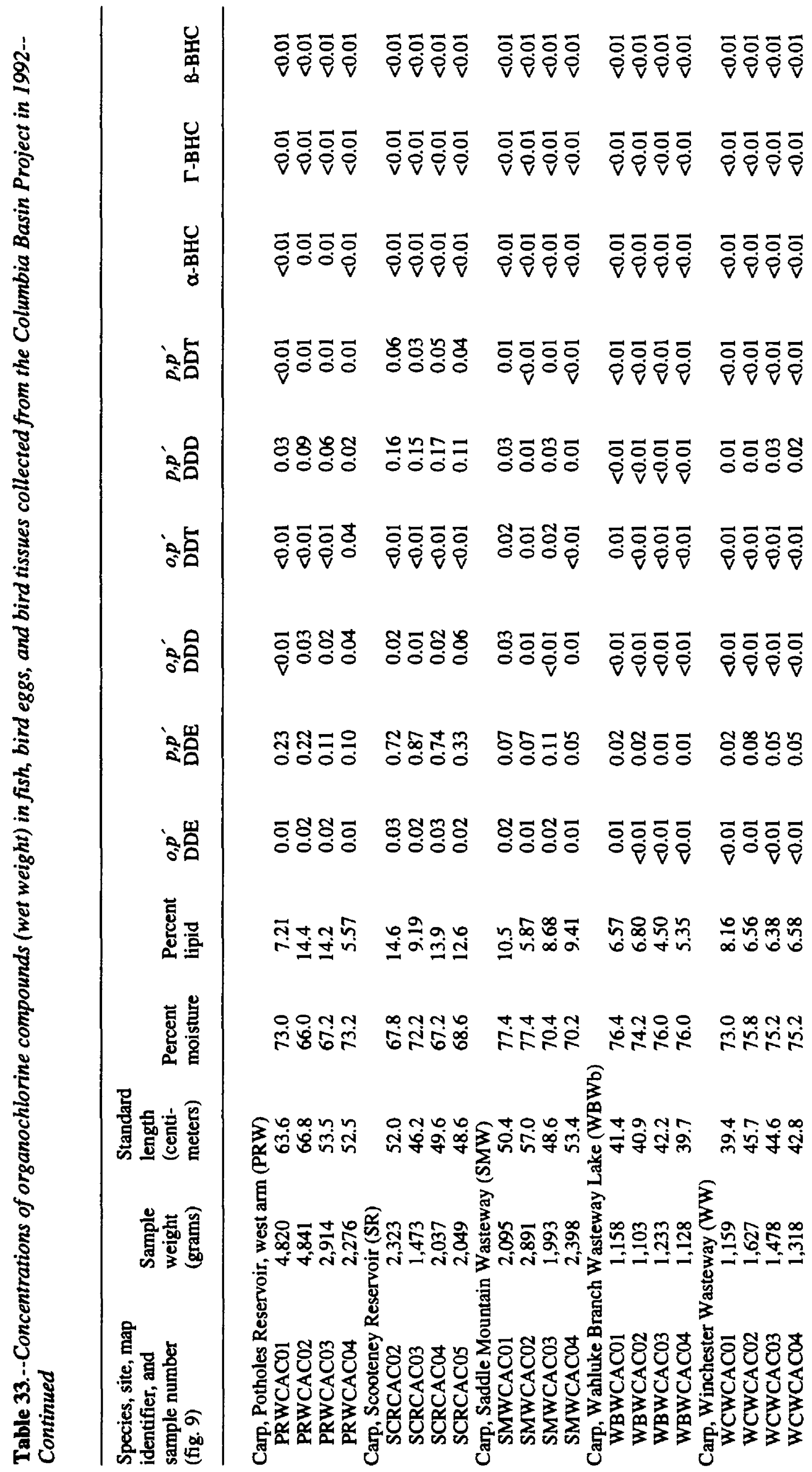




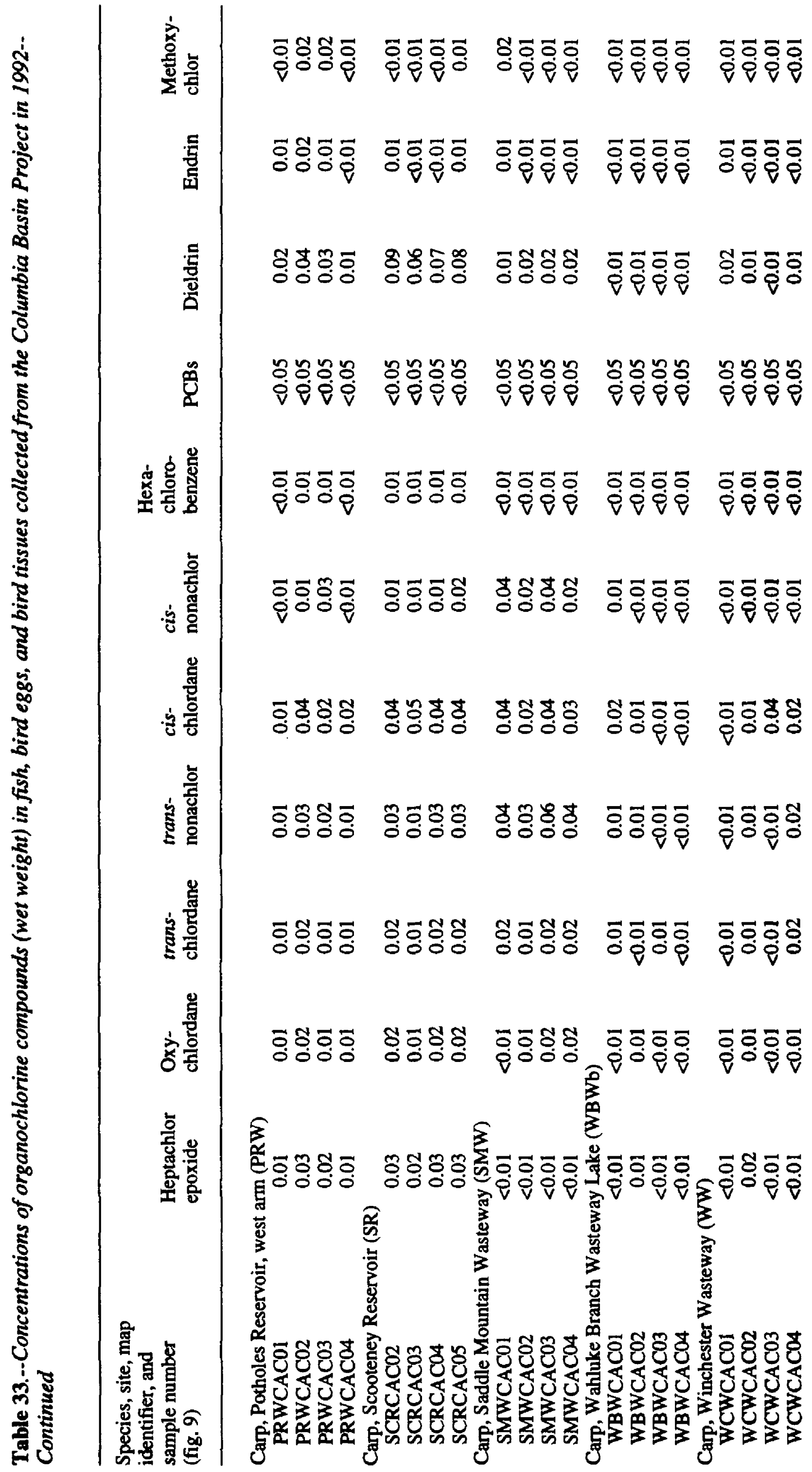




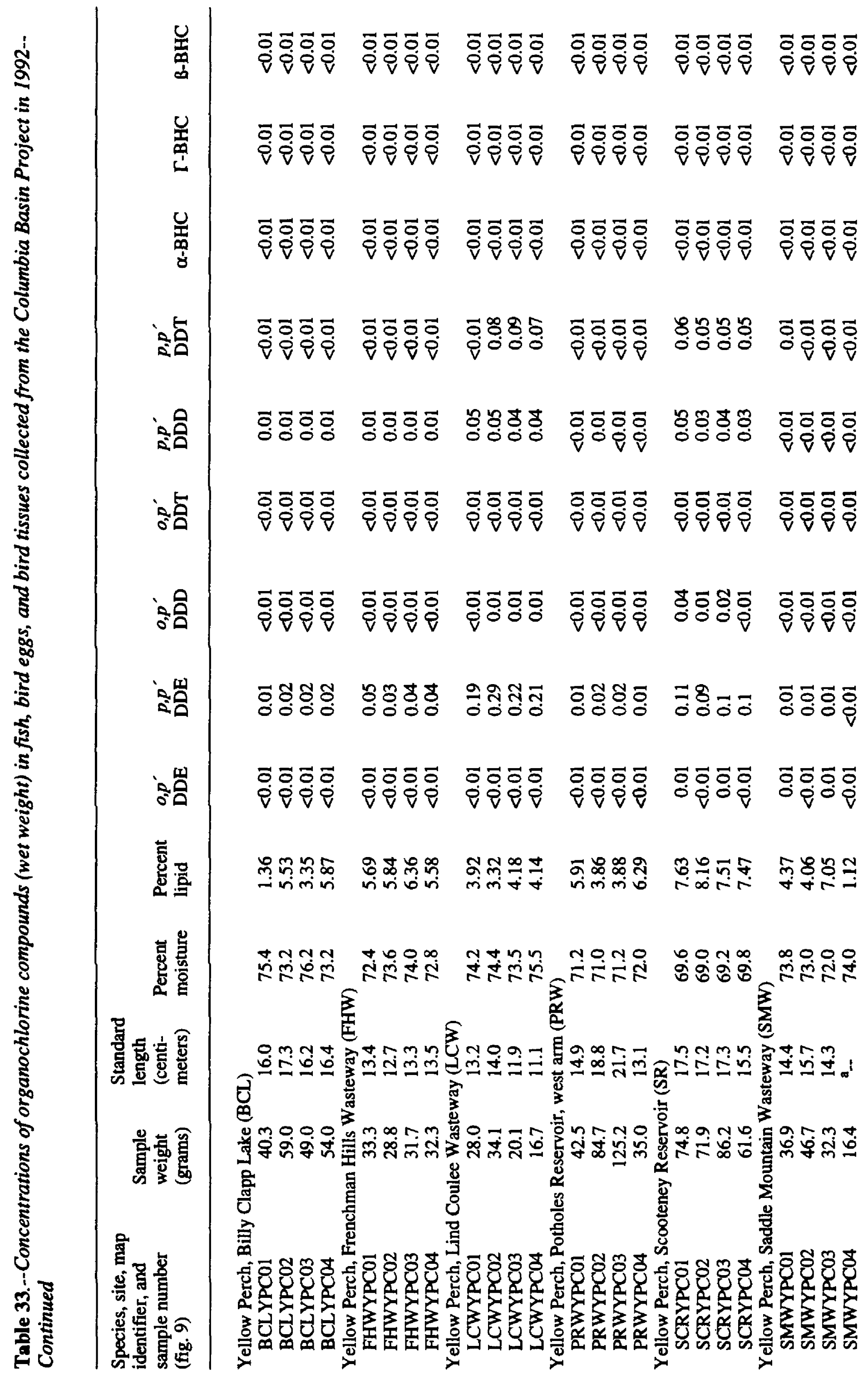




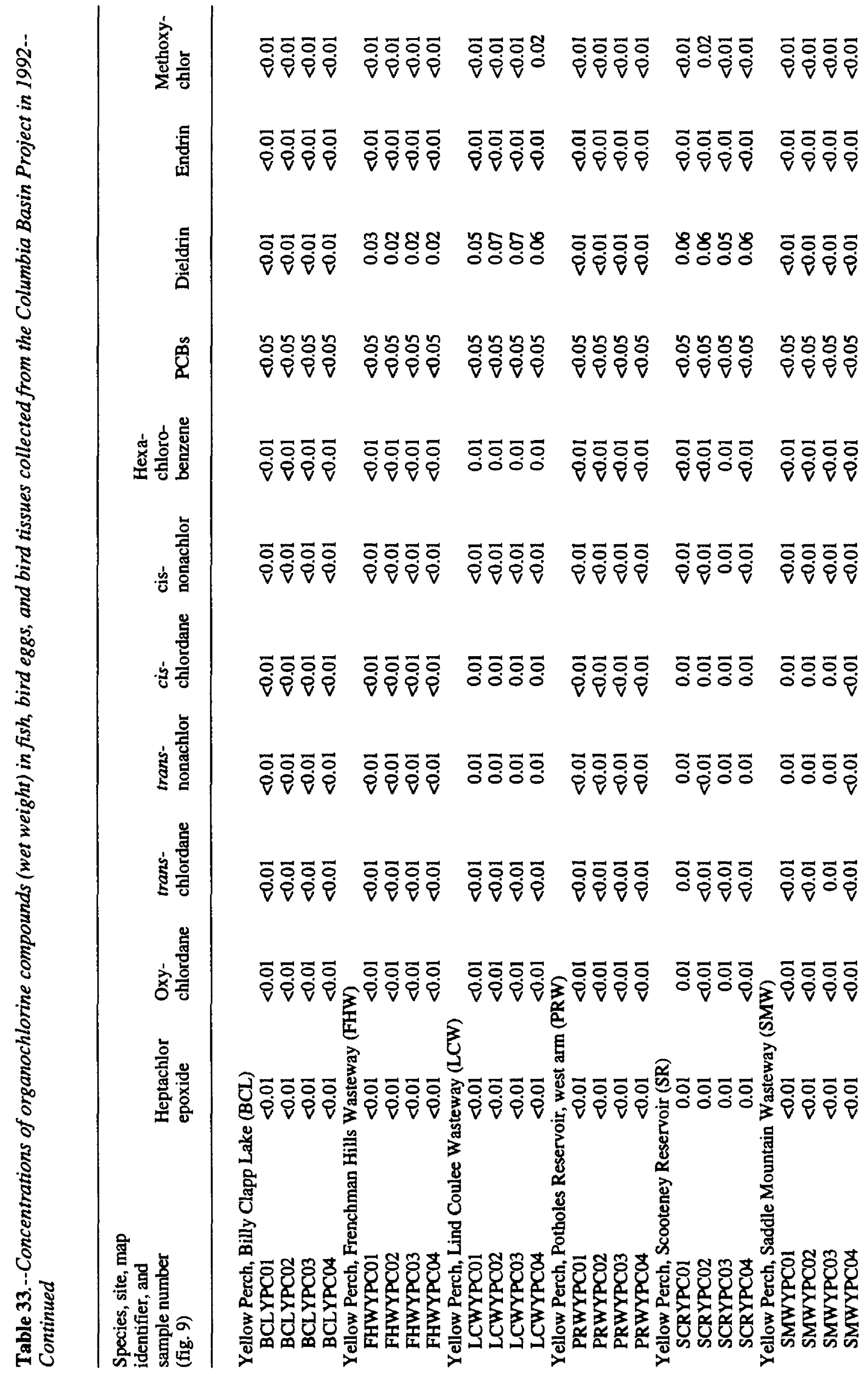




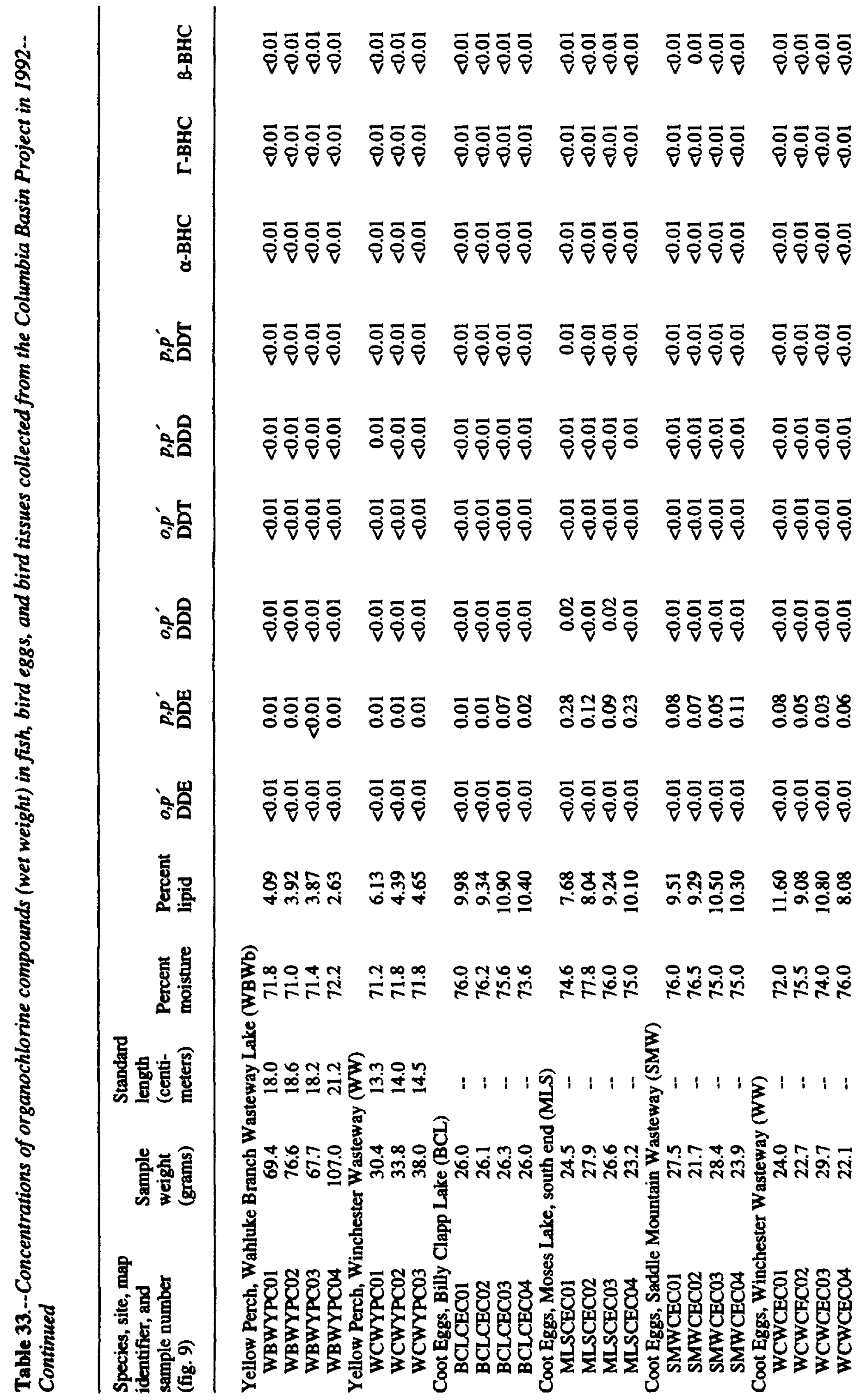




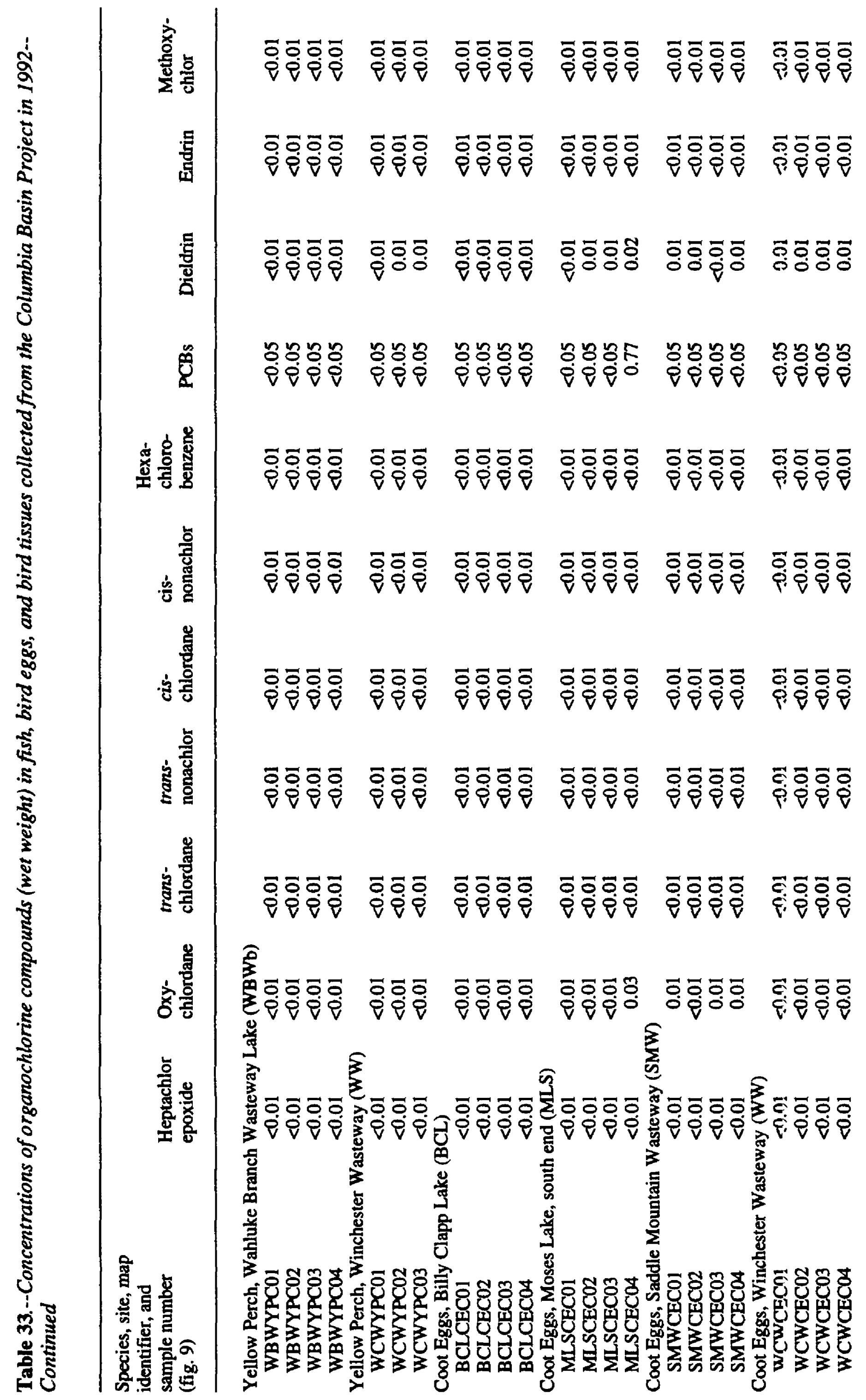




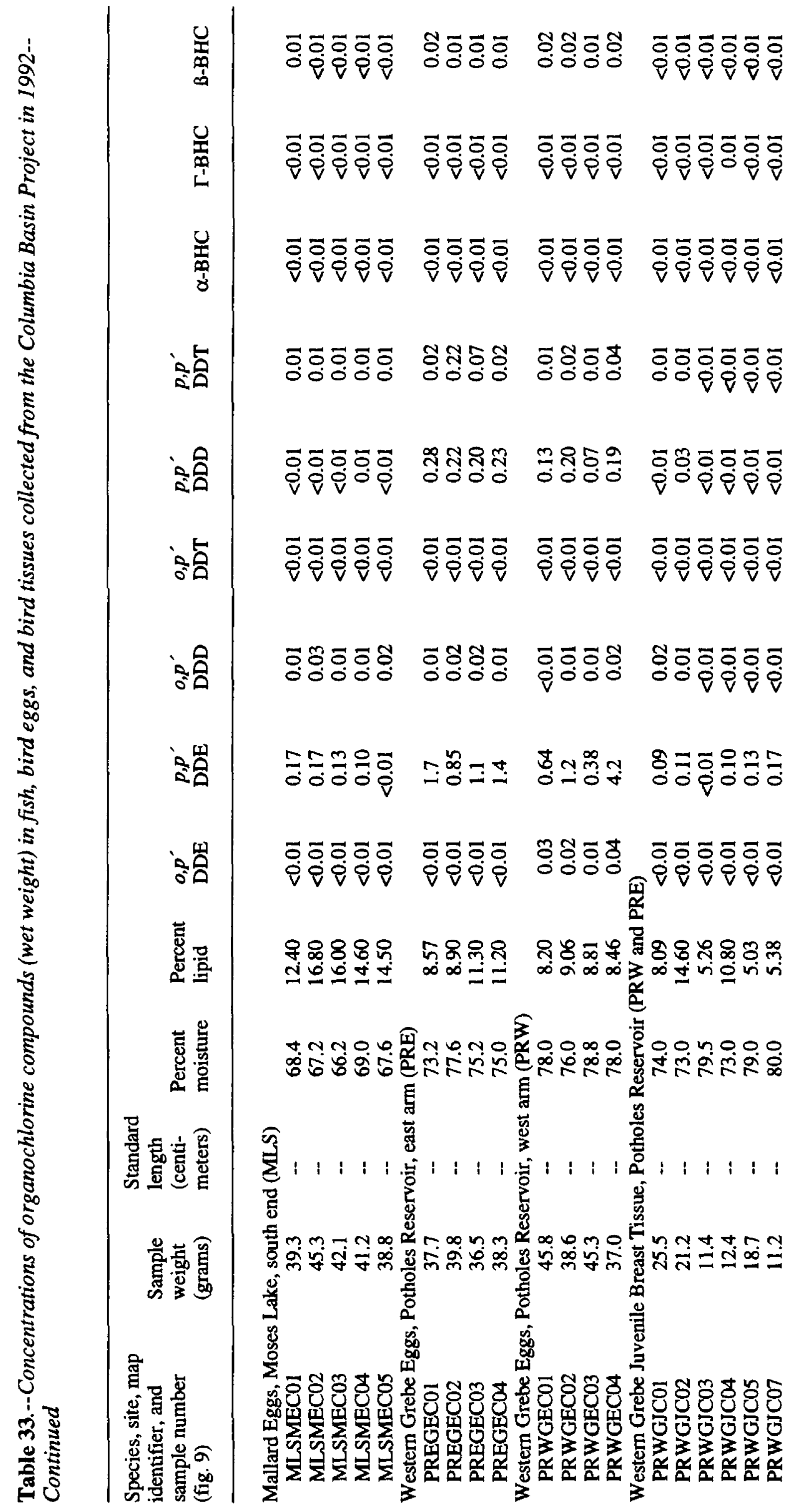




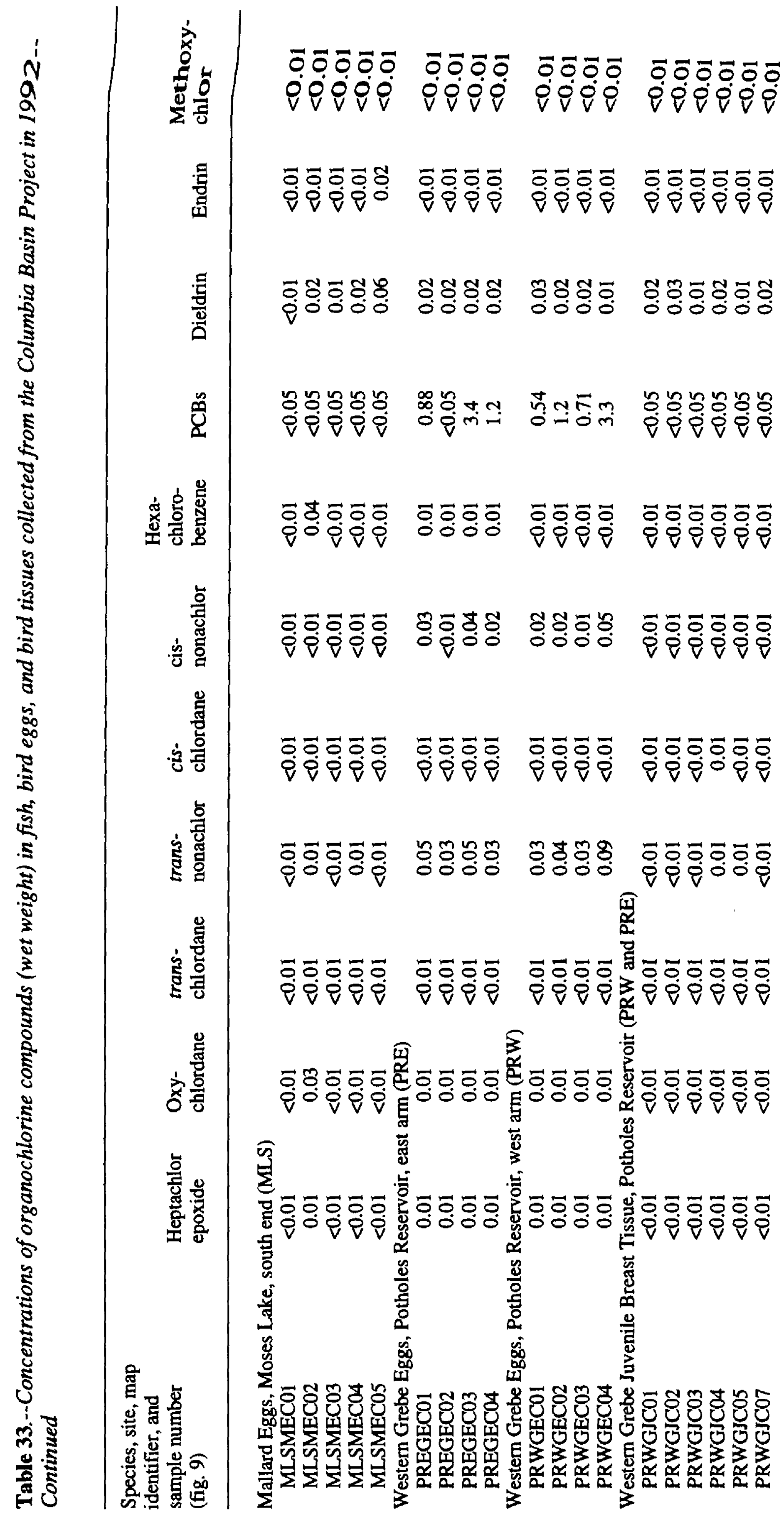




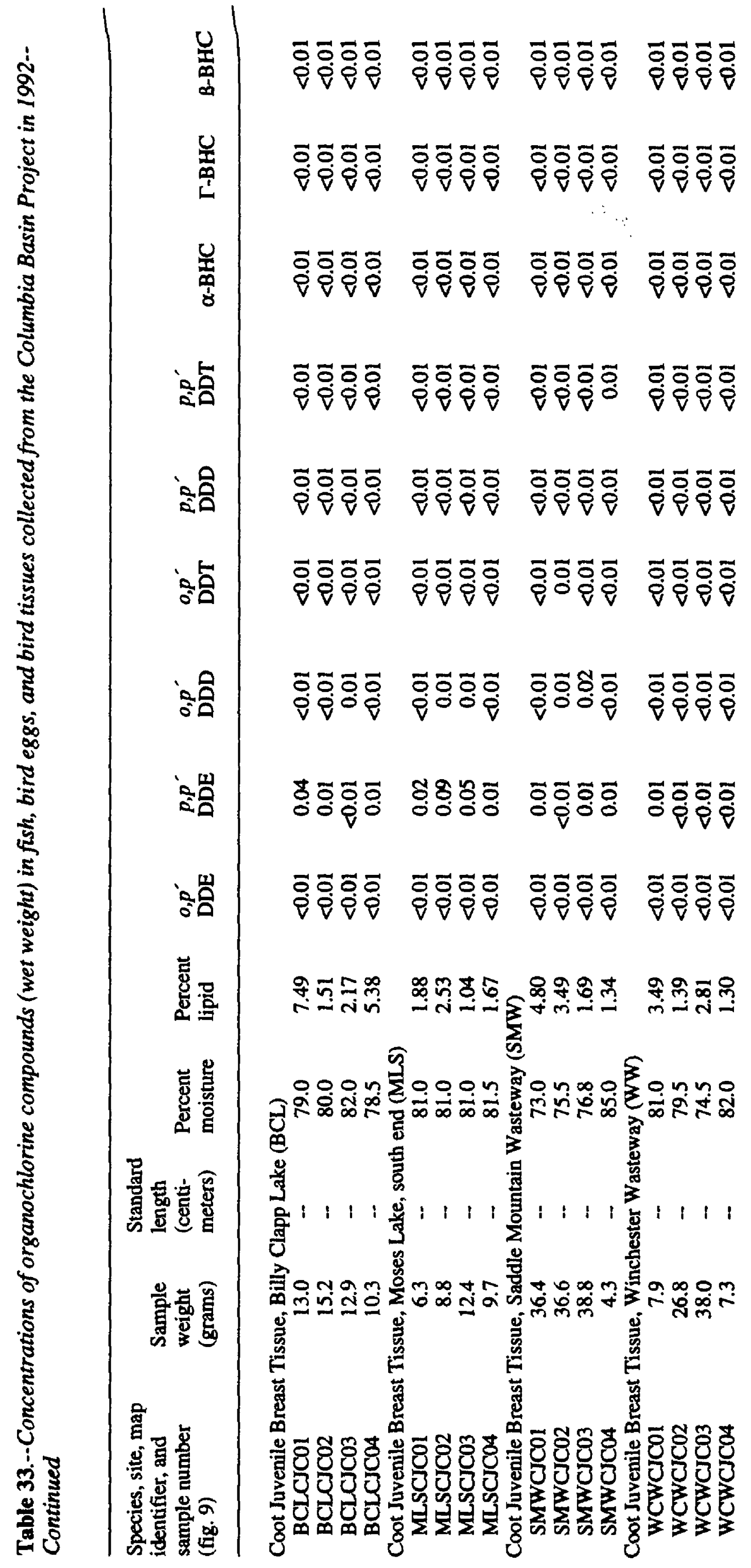




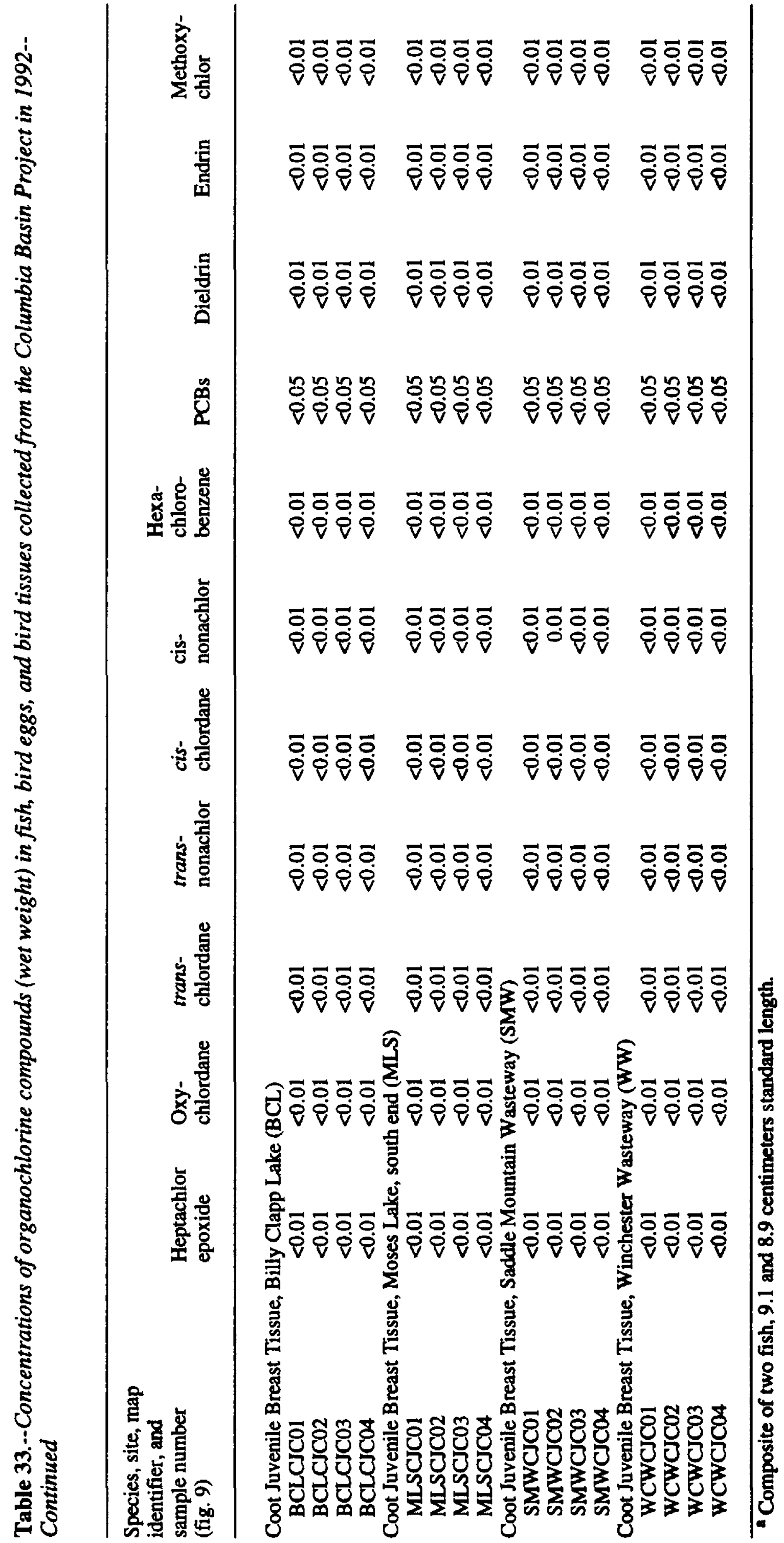


Table 34.--The percent mortality and weight change of Chironomus tentans after exposure to botton sediment collected from the Columbia Basin Project in July 1992

\begin{tabular}{|c|c|c|c|c|c|}
\hline $\begin{array}{l}\text { Site (map identifier) } \\
\text { (fig. 9) }\end{array}$ & $\begin{array}{l}\text { Percent } \\
\text { mortality }\end{array}$ & $\begin{array}{l}\text { Mean } \\
\text { weight } \\
\text { (milligrams) }\end{array}$ & $\begin{array}{l}\text { Standard } \\
\text { deviation }\end{array}$ & $\begin{array}{l}\text { Percent } \\
\text { weight } \\
\text { change } \\
\text { compared } \\
\text { to controls }\end{array}$ & p-value ${ }^{2}$ \\
\hline Control 1 & 20 & 2.7 & 1.28 & 0.00 & -- \\
\hline Control 2 & $\mathbf{0}$ & 3.1 & 1.14 & 0.00 & -- \\
\hline Billy Clapp Lake (BCL) & 20 & 2.3 & 1.43 & 14.94 & 0.25 \\
\hline Rocky Ford Creek (RFC) & 20 & 1.9 & 0.83 & 30.12 & $0.03 *$ \\
\hline Upper Crab Creek (CCU) & 10 & 3.1 & 1.17 & -14.46 & 0.16 \\
\hline Moses Lake, Rocky Ford arm (MLR) & 30 & 2.8 & 1.74 & -1.93 & 0.46 \\
\hline Moses Lake, Parker Horn arm (MLP) & 0 & 3.4 & 0.97 & -24.82 & $0.05^{*}$ \\
\hline Moses Lake, south end (MLS) & $\mathbf{0}$ & 2.9 & 0.71 & -6.51 & 0.32 \\
\hline Potholes Reservoir, west arm (PRW) & 30 & 2.1 & 1.31 & 21.45 & 0.09 \\
\hline Potholes Reservoir, east arm (PRE) & 0 & 3.7 & 1.22 & -18.90 & $0.05^{*}$ \\
\hline Winchester Wasteway (WW) & 50 & 1.8 & 1.59 & 34.22 & $0.03 *$ \\
\hline Frenchman Hills Wasteway (FHW) & 30 & 1.6 & 1.02 & 40.48 & $0.00 *$ \\
\hline Lind Coulee Wasteway (LCW) & 40 & 1.8 & 1.43 & 33.01 & $0.05 *$ \\
\hline Soda Lake (SL) & 10 & 3.8 & 1.78 & -21.44 & 0.07 \\
\hline \multicolumn{6}{|l|}{ Lower Crab Creek, McManamon } \\
\hline $\operatorname{Road}(\mathrm{CCM})$ & 60 & 1.6 & 1.46 & 40.72 & $0.02 *$ \\
\hline Lower Goose Lake (LGL) & 20 & 2.4 & 1.95 & 23.57 & $0.04 *$ \\
\hline \multicolumn{6}{|l|}{ Sand Hollow Creek at mouth } \\
\hline (RB4C Wasteway) (SHCb) & 60 & 1.7 & 1.70 & 38.81 & 0.06 \\
\hline Crab Creek near Beverly (CCB) & 10 & 3.3 & 1.19 & -19.52 & $0.03 *$ \\
\hline Saddle Mountain Wasteway (SMW) & 0 & 3.1 & 1.35 & -1.27 & 0.45 \\
\hline EL68D Wasteway (ELW) & 20 & 2.0 & 1.39 & 24.58 & $0.05^{*}$ \\
\hline Wahluke Branch Wasteway Lake (WBWb) & 0 & 3.4 & 1.24 & -8.70 & 0.23 \\
\hline PE16.4 Wasteway (PEW) & 10 & 2.5 & 1.10 & 7.95 & 0.30 \\
\hline Esquatzel Coulee Wasteway (ECW) & 10 & 3.3 & 1.33 & -21.69 & 0.13 \\
\hline
\end{tabular}

${ }^{1}$ Positive values for percent weight change indicate toxicity (weight loss).

2 p-value less than or equal to 0.05 is significant weight loss.

* significant weight loss. 